UC-NRLF

||||||||||||||||||||||||||||||| ||||||

|||||||||||||||||||||||||||||||||||||

+B 1154? 


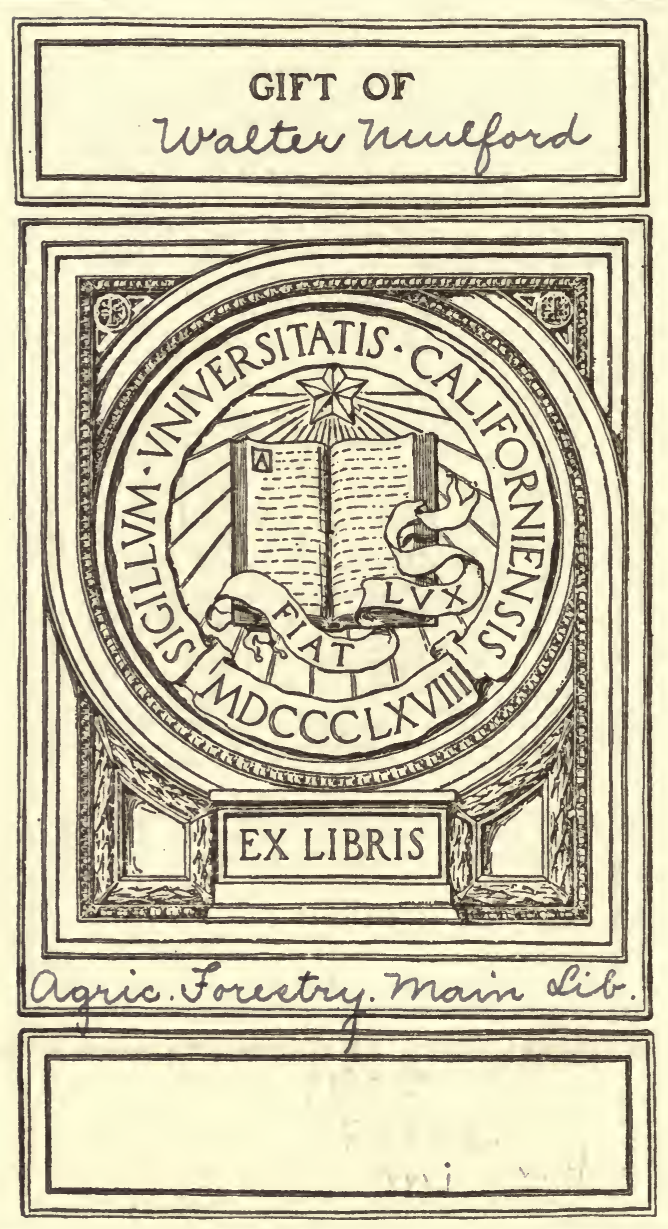






Notes on Bark Structure, by Theo. Krueger. Reprinted from the Forest Club. Annual, Univ. of Nebraska, Vol. IV, 1912.

observations on the 'Inception, Season, and Duration of Cambium Development in the 'American Larch, by $I$. Knudson. Reprinted from the Bulletin of the Torrey Botanical Club 40: 271-293. ue

North American Willows, by W. W. Rowlee. Reprinted from the Bulletin of the Torrey Botanical Club, 27: May, 1900;

A Case of Abnormal Development of a Short Growth in Pinus Excelsa, by Arthur H. Graves. Reprinted from Torrey Vol. 13, No. 6, June, 1913. KC

The Taxonomic Value of the Staminate Flowers of some of the Oaks, by W. W. Rowlee and Susie P. Nichols,

Cornell University.

Growth Studies in Forest Trees -- 1. Pinus Rigida, Mill By Harry P. Brown. Reprinted from the Botanical

Gazette, Vol. IIV, No. 5, November, 1912.

A Study of Pinon Pine, by i. J. Phillips. Reprinted from

the Botanical Gazette 48: No. 3, September 1909. The Bog's and Bog Flora of the Huron River Valley, by Edgar Nelson Transeau, University of Michigan.

on the Geographic Distribution and Ecological Relations of the Bog Plant Societies of North America, by

Edgar N. Transeau, University of Michigan. Reprinte from the Botanical Gazette, 36: 401-420, December, 19 The Evolutionary History of the Foliar Ray, by I. H. Bail (Annals of Botany, Vol. XXVI, No. CIII, JuIy, 1912). Tyloses: Their Occurrence and Practical Significance in Some American Woods, by Eloise Gerry. Reprint from Journal of Agricultural Research, Dept. of Agri., Washington, D. C.

Mier-like Arrangements of the Elements of Certain Woods,

by Samuel J. Record. (Reprinted from Science, N.-S.

Vol. XXXIV, No. 889, Pages 75-77, January 12, 1912). Historic Irees of North America, by W. W. Rowlee. Reprinted from the Plant World, Vol. II, No. 8, Nay, 1899 .

Proceedings of the Washington Academy of Sciences, Vol. V, pp. 403-405. Charles Mohr. 


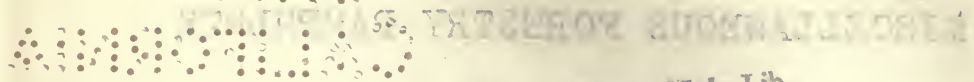

\section{VT . IEY Mata Lib.}

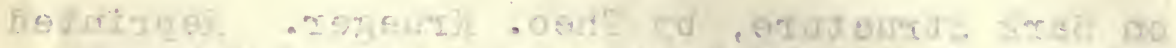

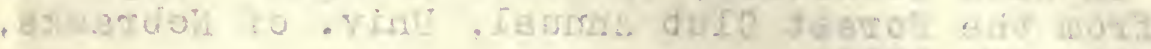
$-24 t$

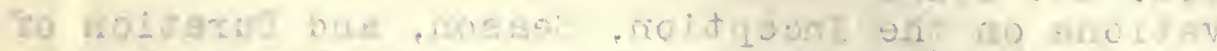

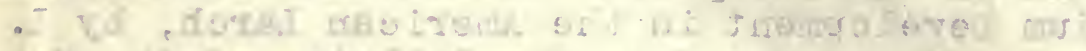

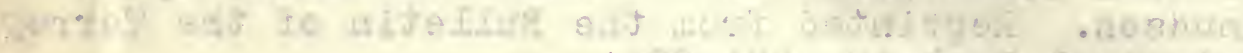

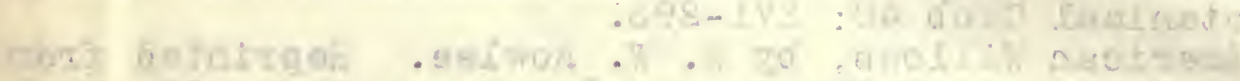

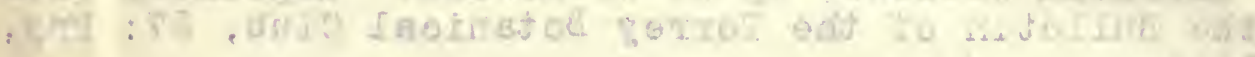

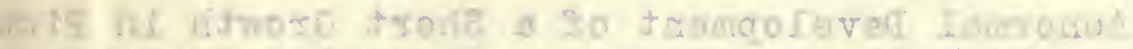

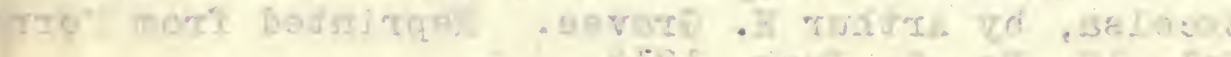
- PIOI rentifs.

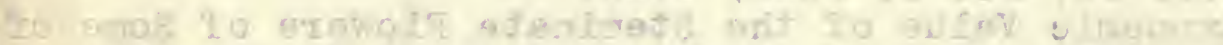
.

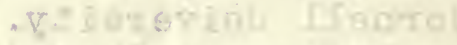

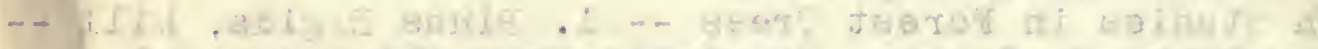

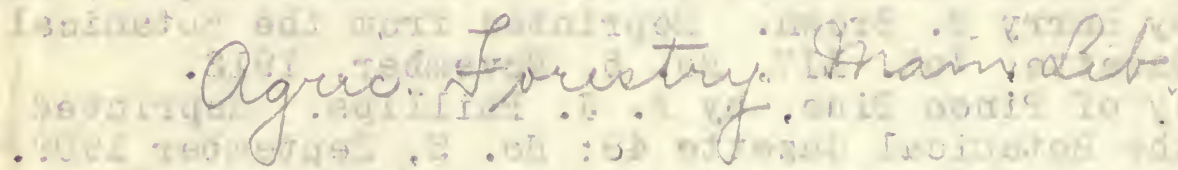
13

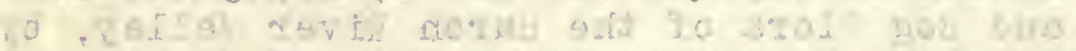

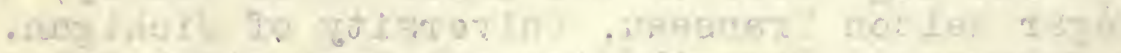

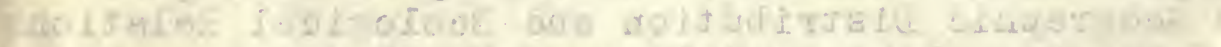

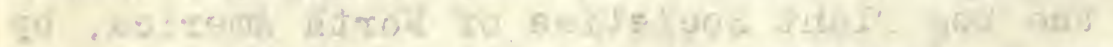

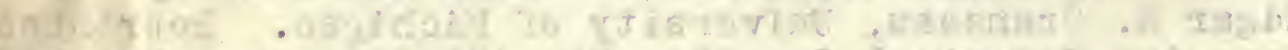

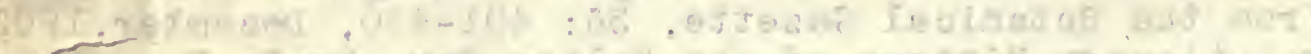

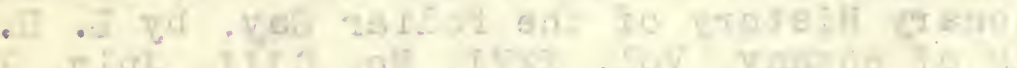

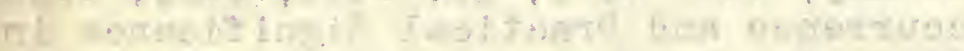

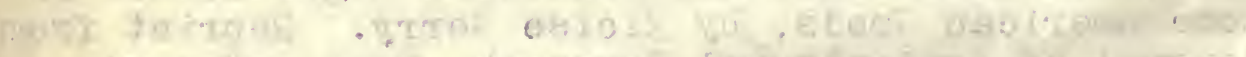

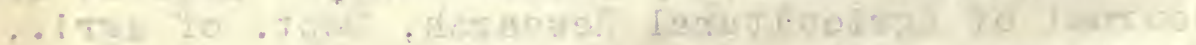

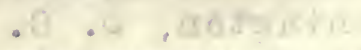

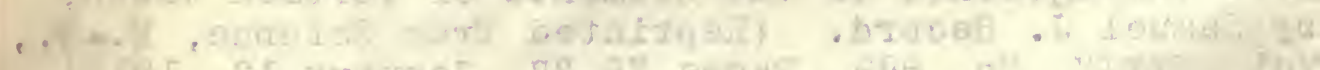

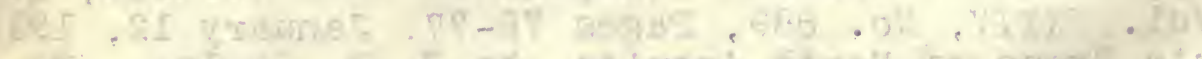

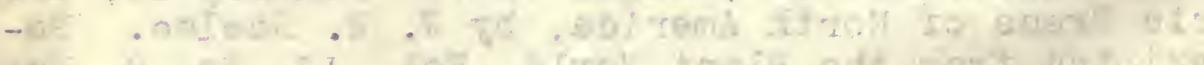

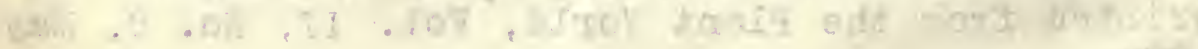
sicte 1

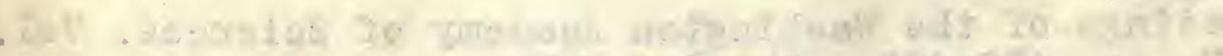

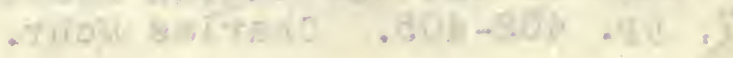




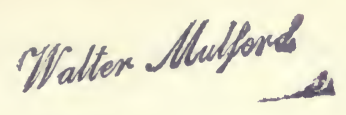

\section{NOTES ON BARK STRUCTURE}

Theo. Krueger.

There is very little material in English on the subject of bark structure, and most of that is of a very general nature. It was thought that the following notes would be useful especially since they deal with the more common genera of American forest trees. They were taken from Dr. Joseph Moeller's "Anatomie der Baumrinden," published in Berlin, 1882, which gives detailed observations of a great many species including a number of American trees. Whether a sufficient number of species in each genus were studied to allow the generalization of structure for the whole genus remains to be shown by further work. No attempt was made in these notes to collect all of the facts brought out concerning our American trees; the idea of the author was to get a step further away from the broad generalizations that are commonly found, by giving the more prominent features of the genera. The characteristics given hold good for the genus only in so far as they apply to the species investigated.

The bark is composed of three more or less distinct parts: the outer bark includes all tissues outside the innermost layer of phellogen; the middle bark includes primary phloem and the phelloderm of the innermost phellogen layer; the inner bark, the secondary phloem inside the innermost layer of phelloderm.

Bark characters are not sufficiently distinct to make an absolutely reliable key for identification.

It cannot be doubted that the formation of "borke", the scales and plates of bark on the outside of the tree, is not governed by a certain stage of development but rather that it is dependent on outside mechanical as well as physiological influences.

\section{CONIFERAE.}

Outer bark. Most conifers develop the periderm during the first vegetative period, and as a rule the epidermis falls off soon afterward. Pinus and Taxodium keep the epidermis 


\section{Notes on Bark Structure}

for a longer time and on Abies it remains often longer than the third year. The phellogen forms in the second to fifth year or even later in Cupressus, Sequoia and Taxus, and the epidermis remains longer and expands as the twig thickens.

The differences in appearance and in the method of shedding the plates and scales are due to the position and the lateral extent of the cork-layers, or periderm. In general the inner cork layers resemble in structure the superficial ones. In Taxus, Sequoia, Abies, Taxodium, Cupressus, Thuja, Libocedrus and Juniperus, the periderm is thin, while in Pinus, Picea and Larix, it is thickened. The periderm in Abies canadensis takes up the coloring matter in alternate layers. The phellogen remains active for more than one vegetative period in Larix and so forms annual layers in its periderm: this in other genera is rare. A sclerotic periderm is almost exclusively characteristic of Pinus. Excellent examples of ring "borke" are found in Thuja, Juniperus, Cupressus, Taxodium and Libocedrus; of scaly bark, in Taxus, Larix, Picea and Pinus; and of bark which does not exfoliate, in Abies.

Middle bark. A hypoderm of sclerotic fibers is found in Cupressus, Thuja, Libocedrus, Picea and Sequoia; while in Pinus and Larix it consists of sclerenchyma cells occurring singly or in groups, around the periphery.

Collenchyma occurs in a typical closed layer in Picea, Abies, and Larix, while in the remaining conifers it appears as a broken layer of regular sized columnar bundles. Abies, Picea, and Larix are characterized by sclerotic cells scattered and also in groups throughout the middle bark; generally they have fantastic shapes and the cells are considerably enlarged. These sclerotic cells do not occur in Pinus, Sequoia, Taxus, Taxodium, Cupressus, Thuja, Libocedrus nor Juniperus.

The phelloderm takes part in the building up of the middle bark in a prominent manner when "borke" formation is late, but is nearly always absent from the inner periderm. It is formed in Pinus and Taxus but always consists of a very few rows of cells even in heavily developed cork layers. In Pinus, Larix and Picea, it becomes hardened (sclerotic).

Crystals of calcium oxalate occur in various ways. They are characteristic of Pinus in the aggregate form. In Libroare characteristic of Pinus in the aggregate form. In Libo- 


\section{Forest Club Annual}

cedrus very fine crystals have been found in the cells, while other genera have crystal sand deposited in the cell-wall, and still others have no crystals whatever.

Primary bast fiber bundles are missing in Taxus, Taxodium, Cupressus, Thuja, Libocedrus, Juniperus and most species of Pinus. They occur in Sequoia and Taxodium as weak bundles with the form of the fibers essentially different from that of the secondary bast fibers.

Inner bark. The secondary bark of Sequoia, Taxus, Taxodium, Cupressus, Thuja, Libocedrus and Juniperus, has as a common characteristic the concentric arrangement of the elements. Pinus, for the greater part, is characterized by the want of bast fibers and a regular arrangement of the elements of the soft bast.

The bast fibers are arranged in single rows. Their radical distance is three rows of cells of the soft bast in Sequoia, Taxus, Taxodium, Cupressus, Thuja, Libocedrus, and Juniperus. In the five last mentioned genera the bast fibers have greatly thickened walls and occur in tangential rows in which the slightly sclerotic fibers are occasionally interpolated, and these are nearly always arranged in several tangential rows. The latter is generally the case in Taxus where a row of thin walled fibers occur between every two rows of sclerotic fibers. In Sequoia all of the bast fibers were found to be entirely sclerotic and here and there stone cells occur. Pinus forms no stone cells, while in Abies, Picea and Larix, sclerotic cells are present.

If the soft bast consists of only three rows of cells which are enclosed between bast fiber layers (Sequoia, Taxus, Taxodium, Cupressus, Thuja, Libocedrus and Juniperus) then the middle row is parenchyma and the row on each side is made up of sieve tubes. This periodic change in the formation of the elements is demonstrated also in Pinus where several layers of sieve tubes are always separated by simple and less numerous rows of parenchyma. The parenchyma cells have large pits; the sieve tubes, which have no cross-plates, are covered along the whole wall with fine-pored sieve plates.

Schizogenous resin pockets are wanting in the secondary bark excepting in Thuja where they were found in the outside layers. On the other hand lysigenous resin cysts are charac 


\section{Notes on Bark Structure}

teristic of Taxodium, Cupressus, Thuja, Libocedrus, and Juniperus.

Calcium oxalate occurs in Pinus in the same form as in the middle bark. In Taxodium, Cupressus, Thuja, Libocedrus, and Juniperus, the radial membranes of all elements and in Taxus the whole wall of the bast fibers and stone cells receive deposits of very small erystals.

All conifers have pith rays of a single row of cells, excepting in Pinus and Picea, where they broaden out to make room for a resin canal.

Key to the Genera:

A. Bast fibers (on cross-section rounded-rectangular) in concentric mostly single rows; 3 rows of soft bast.

1. Bast fibers very thick walled; here and there large stone cells with relatively thin walls.

Sequoia

2. Thick walled and thin walled fibers alternating; no stone cells.

(a) Crystals in the walls of the bast fibers; bast parenchyma thick walled, large pitted, free from resin; scaly bark.

Taxus

(b) Crystals in all the radial walls; resin cysts; ring "borke." (No safe distinctions in the structure of the bast.)

Taxodium

Cupressus

Thuja

Libocedrus

Juniperus

B. Bast fibers wanting.

1. No sclerenchyma except the hard walled cork layers; crystals prism-shaped.

Pinus

2. Scattered stone cells in the soft bast; isodiametric crystals.

(a) Branched stone cells mostly combined in groups.

(x) Cork layer thin walled.

, Abies

(y) Cork hard walled; often sclerotic phelloderm. 
b. Spindle form, mostly isolated bast-fiber-like stone cells; broad thin-walled cork layer with a narrow layer of sclerotic cork cells.

Larix

JULIFLORAE.*

Outer bark. In Salix the phellogen originates in the epidermis, in the other genera of this group it originates in the outermost layer of cells of the primary bark. On a year old twig usually several layers of cork are present. The epidermis remains on not longer than the second or third vegetative season while the superficial periderm renews itself for a longer period of years, certainly through a decade, and is only exceptionally or perhaps not at all thrown off in Betula, Fagus and Carpinus.

Strong walled plate cork is formed in Betula, Alnus, Liquidambar, Ostrya, Carpinus, Corylus; Quercus, Fagus and Castanea. Cubical and thin walled cork cells predominate in Celtis, Ulmus, Morus, Platanus, Populus and Salix; all of these except Ulmus form stone-cork plates.

Middle bark. The characteristics of the middle bark are found in the presence of secretion cavities and in the occurrence of sclerenchyma, and perhaps the most noticeable feature is the never failing presence of calcium oxalate crystals in all the genera of this group.

In the occurrence of sclerotic parenchyma several modifications may be distinguished, of which three are given below:

(a) The sclerenchyma accompanies the primary bast fibers and forms a closed ring of mixed stone-cells and bast fibers in Betula, Alnus, Ostrya, Carpinus and Corylus.

(b) Besides the closed ring mentioned in (a), sclerotic cells occur singly or in groups scittered throughout the whole region of the middle bark in Celtis, Quercus, Fagus, and Castanea.

(c) The parenchyma does not become sclerotic in Ulmus and in some species of Morus, Salix and Populus.

The phelloderm takes a prominent part in building up the middle bark in those species which have a persistent superficial periderm, and a rather insignificant part in those which do not have. Since the parenchyma of the middle bark does not undergo an unusual tangential stretching, and the primary

*Eichler's classification. 


\section{Notes on Bark Structure}

pith rays widen only very little, the growth in thickness must occur through division of the parenchyma of the entire bark.

Inner bark. In the secondary bark there is no characteristic common to all the genera of this group. Betula, Alnus, Platanus, and Fagus are characterized by the absence of bast fibers. Sclerotic bast parenchyma and bast fibers are both found in Ostrya, Carpinus, Corylus, Quercus, Fagus, Castanea, licltis, Morus, Liquidambar and a few species of Populus, while bast fibers only and no sclerenchyma are found in Ulmus, Morus, and in some species of Salix and Populus. Several genera are characterized by bast fibers which differ from the usual typical appearance on account of their greater length, unusual fineness, elasticity and cross sectional form; among these are Ulmus, Celtis, and Morus; while in Liquidambar they look somewhat like stone cells.

The soft bast in all of these genera is composed of sieve tubes, parenchyma, and crystal cells. To these elements are added mucilage cells in Ulmus and latex tubes in Morus. The sclerotic parenchyma cells have a characteristic appearance in some of the genera; in Quercus they are very much thickened and have very many fine pores; while in Platanus they are only slightly thickened and have broad pores.

The variation in form of erystals and the manner of their distribution throughout the inner bark allows the following characteristics to be listed:

A. Single crystals alone or at least a crystal aggregate.

1. Between the sclerenchyma cells; bast fibers wanting. Platanus

2. In sclerotic companion cells accompanying the bast fiber bundles.

Liquidambar

3. Independent of details of the fiber bundles.

(a) Exclusively single crystals.

Ulmus

Celtis

(b) Sometimes a.'so crystal aggregates.

Morus

B. Single erystals and e vystal aggregates always present together.

1. Single crystals clotie the tangential areas of the bast fiber bundles. 


\section{Forest Club Annual}

(a) Crystal aggregates in soft bast.

Quercus

Castanea

Salix

Populus

(b) Crystal aggregates and single erystals in the soft bast.

Ostrya

Carpinus

2. Crystal aggregates primarily in the soft bast and single crystals in the sclerenchyma; bast fibers wanting.

Betula

Alnus

Fagis

Most of the genera have very proad pith rays, i. e. of more than one row of cells; only Alnus, Castanea, Salix and Populus have been composed of one row.

In Fagus, Quercus, Ostrya, Carpinus, Liquidambar and generally in Platanus the walls of pith rays become sclerotic where they adjoin sclerenchyma tissues; while in Betula, Alnus, Castanea, Corylus, Salix and Populus they remain thin-walled. Pith rays entirely separated from bast strands were found to be sclerotic in Quercus, Fagus, and Platanus.

In the genera which have pith rays of only one row of cells, no crystals were observed. Crystals in large amounts were found in the pith rays of Ostrya, Carpinus and Corylus; small amounts in Quercus, Fagus, and Plantanus; and only very few were found in the rays of Betula, Castanea, Ulmus, Celtis, Morus, and Liquidambar.

Key to the Genera:

A. Bast fibers wanting.

1. Bast parenchyma largely changed into moderately thickened stone cells, which, as well as wide partly sclerotic pith rays, contain erystals.

Platanus

2. Scattered groups of very much thickened stone cells.

(a) The sieve tube elements have a single wide pored cross-plate. 


\section{Notes on Bark Structure}

(b) Numerous sieve plates arranged ladder-like. (x) Pith rays in one row

(y) Pith rays in several rows.

B. Bast fibers present, but there are none, or only very few stone cells.

1. Extensive, closely packed bast fiber bundles in tangential rows accompanied by crystal cells; sieve tubes with ladder-form plate system; pith rays of one row.

(One species of Populus develops sclerenchyma.)

Salix

Populus

2. Small bast fiber bundles, loosely grouped and independent of crystal cells; sieve tubes with simple crossplates; pith rays with more than one row.

(a) Mucilage cells in soft bast; no stone cells.

Ulmus

(b) Latex tubes in the soft bast; sclerenchyma present.

Morus

C. Bast fibers and sclerenchyma both always present.

1. Bast fiber bundles grouped exclusively in large concentric tangential rows, and accompanied by erystal cells.

(a) Sclerenchyma predominating; pith rays broad, may become sclerotic, any place.

Quercus

(b) Regularity of the layers not influenced by the small amount of sclerenchyma present; pith rays one row.

Castanea

2. Bast fibers short and knotty combined with stone cells into plates and accompanied by crystal cells; pith rays of several rows.

Liquidambar

3. The rows of bast fiber bundles frequently indistinct.

(a) The bast fiber bundles accompanied by erystal cells. 
(x) Crystal cells with crystal aggregates in large amounts accompanying the bast fibers.

Corylus

(y) Crystal aggregates only in soft bast; single crystals accompanying the sclerotic elements of the bast and the pith rays.

(m) Bast fiber plates in step-like layers.

Ostrya

(n ) Bast fibers grouped predominantly radially or scattered; primary sclerenchyma ring is complete.

Carpinus

(b) Bast fiber bundles, small amount and loosely arranged, not surrounded by crystal cells.

\section{Fraxinus.}

Celtis

Duter bark. The periderm develops during the first vegetative period. It originates in the layers of cells of the primary bark, immediately under the epidermis. The outer bark remains thin as a consequence of the quick shedding of the superficial layers.

Middle bark. The primary bark is collenchyma like. The stone cells appear only in isolated groups and at first in the spaces between the primary bast bundles but without elosing together to complete a sclerenchyma ring. Calcium oxalate occurs in the form of very delicate short crystal needles.

Inner bark. Bast fibers accompanied by stone cells from regrular tangential concentric bands. The bast fibers are of typical form. The soft bast always forms a very large part of the inner bark. Calcium oxalate occurs as crystal sand or in very minute pointed crystals. The pith rays are very often only one or two rows wide. They contain a large amount of crystals in the same form as the bast parenchyma.

An important characteristic of Fraxinus bark is the partial thickening of the pith ray cell walls where they pass between the sclerotic bundles.

Summary :

Sclerenchyma groups are mixed with bast fibers and stone cells in regular concentric arrangement; pith rays occasionally partly sclerotic; bast fibers of typical form; crystal sand and delicate prisms occur in the soft bast and 


\section{Notes on Bark Structure}

in the pith rays; sieve tubes wide with very large and netlike sieve fields.

Fraxinus

Catalpa.

Outer bark. The periderm is always developed early in the outermost layer of cells of the primary bark. The cells of the cork layer are large, slightly flattened and thin-walled. Catalpa has scaly bark.

Middle bark. The primary bark is of typical collenchyma, and contains no crystals. It never becomes sclerotic.

Inner bark. The secondary bark contains bast fibers in concentric tangential bands, but no stone cells. The soft bast consists mainly of parenchyma and contains an abundance of calcium oxalate in the form of either crystal sand, raphides, or small prisms, without reference to the bast fibers. The pith rays are never more than four rows wide, are never sclerotic and are filled with the same form of crystals as those found in the bast parenchyma.

The most striking characteristic is the absence of stone cell formation in the middle and inner bark.

Summary :

Bast fibers never accompanied by crystals, no stone cells in the secondary bark; pith rays always thin walled. Bast fibers in tangential bands broken only by pith rays; the latter of several rows of cells containing an abundance of raphides and crystal sand as does also the bast parenchyma. The layers of soft bast much broader than those of the bast fibers.

Catalpa

\section{Magnoliaceae.}

Outer bark. The periderm develops early. The phellogen originates in the layer of cells immediately adjoining the epidermis. The superficial periderm consists of a few rows of thin-walled cells. The inner periderm is characterized by a layer-like thickening of the cork.

Middle bark. A closed although rather weak hypoderma of collenchyma is formed. Short secretion cells are especially characteristic. Sclerotic idioblasts are formed in the middle bark of Magnolia. Calcium oxalate is present in Liriodendron in the form of fine sand. 
Inner bark. The bast fibers are regularly arranged in concentric layers. In Magnolia they are mixed with stone cells. The bast parenchyma does not become sclerotic in Liriodendron while in Magnolia it does,but only in the outer layers. Stone cells in Magnolia are essentially enlarged and very thick walled. The bast fibers in Magnolia have a typical form while in Liriodendron they are often tangentially flattened. Calcium oxalate is wanting in Magnolia and occurs in Liriodendron as sand. Magnolia is characterized by secretion cells which are developed from single parenchyma cells. Pith rays are usually not more than three rows wide, but become broader as they approach the middle bark. Their cells are more delicately walled than the bast parenchyma and are generally radially stretched.

Key to Genera:

Bast fibers arranged in regular concentric layers.

1. The layers are a mixture of bast fibers and stone cells. In the young bast of the bundle the stone cells are branched. The sieve tubes are very wide. (In the inner bast layers stone cells are wanting).

Magnolia

2. The layers contain bast only; stone cells are wanting. The inner periderm is made up of alternate layers of thin and thick walled cells.

Liriodendron

\section{Tilia.}

Outer bark. The phellogen has its origin in the layer of cells immediately adjoining the epidermis. The superficial periderm is fully developed at the end of the first vegetative period; it is thick-walled and like the inner periderm in structure. The collenchyma is small celled.

Middle bark. Typical collenchyma forms the outer layer. The pelloderm is always found in Tilia. The slight tendency to form sclerotic cells is characteristic. Calcium oxalate is found in large quantities in the form of crystal aggregates.

Inner bark. Bast bands are many cells broad and irregular in width due to a bunching of the fibers in pliaces. The bast fibers are always very long, straight and elastic, and are thickened not less than one-third their width. No crystals are present. The crystal cells contain peculiar large prisms, and 


\section{Notes on Bark Structure}

almost completely surround the bast bundle. The parenchyma cells are nearly as wide as the bast fibers; they never develop into mucilage cells and are never sclerotic. The sieve tubes are broader than the parenchyma, and their ends are slanted and contain several sieve plates. Some of the pith ray cells show between fiber bundles, a trace of sclerotic wall. Summary :

Tangential bast fiber bundles surrounded by crystal cells. Pith rays broad and wider toward the outside. Sieve-tubes with ladder-like end plates; crystals large, prismatic. Crystal-aggregates in primary pith rays; cork layer evenly small-celled.

Tilia

\section{Leguminosae.}

Outer bark. The phellogen develops from a fourth to sixth row of cells below the epidermis in the primary bark of Robinia; in Gleditsia from the second or third row and in Gymnocladus, from the row immediately adjoining the epidermis. The first formed periderm expands with the growth in thickness of the twig for several years in Robinia. The superficial periderm rarely reaches large dimensions despite its long persistance. In both Robinia and Gleditsia it. consists of thinwalled spongy cork while in Gymnocladus it is thick walled. The cork cells are for the greater part cubical or only slightly flattened in form.

Middle bark. The hypoderma of collenchyma cells is either wanting or is only slightly developed. The thin-walled closely fitting parenchyma cells of the primary bark begin, in very young internodes, to become sclerotic between the bast fiber bundles and thus close the thick walled cells into a ring. This feature is characteristic of the Leguminosae, as also is the presence of very few crystals in the primary bark. Single crystals are formed in the region of the stone cells and in the thin walled parenchyma.

Inner bark. A characteristic of the Leguminosae is that the development of the pith rays is never influenced by the bast strands. The latter form concentric layers in Gymnocladus and Gleditsia. The crystal cells are thin-walled in Robinia, and partly sclerotic in Gleditsia and Gymnocladus. The soft bast of the two last mentioned genera is composed of 
bast fiber bundles surrounded with a layer of parenchyma and that in turn by layers of sieve tubes and layers of parenchyma alternating. In Gleditsia, only, a few aggregate crystals were found. The parenchyma cells are always a little wider than the bast fibers. The sieve tubes in Robinia are short, just a little wider than the parenchyma cells, and have simple cross plates; those of Gleditsia are much shorter. The pith rays are generally more than four rows wide, and rarely contain stone cells.

Key to the Genera:

Bast fiber bundles or plates in tangential rows eut through by broad pith rays.

1. Sieve tubes with lattice end-plates; bast fiber bundles enclosed by crystal cells, or at least accompanied by them in large quantities. Bundle rows frequently interrupted, accompanied by stone cells, between them smaller bundles and single fibers. Bast fibers more than $1 \mathrm{~mm}$. long, crooked knotty.

(a) Sieve tube elements many times broader than parenchyma, with few sieve plates.

Gymnocladus

(b) Sieve tube elements not noticeably broad, with large number of coarse pored sieve-plates; crystal aggregates in the bast parenchyma and pith rays.

Gleditsia

2. Sieve tubes with simple cross-plates; bast fiber bundles surrounded by crystal cells, layers of bast fiber bundles alternate with broader and larger celled layers of soft bast; no stone cells; pith rays of even width.

Robinia

Acer.

Outer bark. The superficial periderm develops in the first vegetative period from the laver of cells, immediately under the epidermis.

Middle bark. Collenchyma is present; massive primary strands are developed. Calcium oxalate is found in rhomboidal crystals.

Inner bark. Stone cells slightly enlarged form an equal 
or even larger part of the inner bark than do the bast fibers. In older age, the layers of bast fibers are formed only at intervals of many years. The fibers are thin, smooth and long pointed. The sieve tubes, with simple horizontal cross-plates, are arranged in layers alternating with layers of parenchyma. The former are thinner walled. The crystal cells always contain rhomboidal single crystals. Pith rays are three to five rows wide; the cells with thinner walls than the bast parenchyma and stretching radially. The cell walls where immediately joining sclerotic cells do not become thickened.

\section{Summary :}

The secondary bark contains layers of bast fibers alternating with larger layers of stone cells. The former are surrounded by crystal cells. Pith rays are broad. Summary :

List of genera mentioned, the number of species of each that were studied, and what American species investigated. CONIFERS.

Juniperus, 3 species.

J. communis $\mathrm{L}$.

J. virginiana L.

Thuja, 3 species.

T. occidentalis $\mathrm{L}$.

T. gigantae Nutt. Cupressus, 1 species.

None American.

Sequoia, 1 species.

S. gigantea Endl.

Larix, 2 species.

None American.

Betula, 2 species.

None American. Alnus, 2 species.

A. incana Willd.

Ostrya, 1 species.

O. virginica $\mathrm{L}$.

Carpinus, 1 species.

None American.
Abies, 2 species.

A. canadensis Mill.

Picea, 1 species.

None American.

Taxus, 1 species.

None American.

Taxodium, 1 species.

T. distichum Rich.

Pinus, 5 species.

P. strobus L.

BROADLEAF.

Corylus, 2 species.

None American.

Platanus, 1 species.

None American.

Liquidambar, 1 species

None American.

Populus, 4 species.

$P$. tremula L. 


\section{Forest Club Annual}

Salix, 2 species

$S$. fragilis $\mathrm{L}$.

Fraximus, 3 species.

F. nigra Marsh.

Quercus, 6 species

Q. rubra $\mathrm{L}$.

Castanea, 1 species.

None American.

Ulmus, 4 species.

U. fulva Michx.

Celtis, 2 species.

C. occidentalis $\mathrm{L}$.

Morus, 2 species.

None American.

Maclura, 1 species.

M. aurantiaca Nutt.

Carya, 1 species.

C. amara Nutt.
Robinia, 1 species.

R. pseudacacia L.

Gleditsia, 2 speies.

G. triacanthos L.

Gymocladus, 1 species.

G. canadensis. Lam.

Catalpa, 1 species.

C. syringaefolia Sims.

Magnolia, 1 species.

M. acuminata L.

Liriodendron, 1 species.

L. tulipifera $\mathrm{L}$.

Tilia, 3 species.

T. americana L.

Acer, 4 species.

A. negundo L.

Juglans, 3 species.

J. nigra L. 

[From the Bulletin of the Trreky Botanical Club40:271-293. I9 Jnne 1913.]

\section{Walter Muifours}

Observations on the inception, season, and duration of cambium development in the American larch [Larix laricina

(Du Roi) Koch.]*

L. KNudson

(WITH PLATES I8 AND I9)

\section{INTRODUCTORY}

During the past twenty-five years very little attention has been devoted to a minute study of the diameter increase in trees. Comparatively little is known concerning the season of wood formation; and with respect to the region of the tree in which diameter increase first begins, the êvidence is contradictory. With the object of determining the part of the tree in which cambial activity begins, as well as to determine the season of growth, investigations were begun during the season of 1909 . and continued in I9II. The results obtained from the study of material collected these two seasons form the basis of this paper.

The subject was suggested by Prof. W. W. Rowlee, and to him, as well as to Prof. B. M. Duggar, the writer is indebted for helpful suggestions.

\section{HISTORICAL}

The work of von Nordlinger, Th. Hartig, Robt. Hartig, Mer, and others has thrown some light upon the extent and duration of cambial activity. They have found, in general, that under forest conditions growth first begins in the youngest twigs and then proceeds downward into the older regions. Less work has been done on the cambial activity in isolated trees.

Concerning the region of first cambial activity, Th. Hartig $\dagger$ concluded that it occurred in the youngest twigs and then gradually extended downward. In a 30-year old Pinus sylvestris, and also in oak, cambial activity began almost simultaneously over the entire trunk, while in larch and maple of the same age cambial

* Laboratory of Plant Physiology, Cornell University, Contribution No. 8.

† Hartig. T. Anatomie und Physiologie der Holzpflanzen, 368. 1878. 


\section{Knudson: Cambium developmemt in American Larch}

activity began from two to four weeks later in the lower part of the trunk than in the twigs.

As a result of extensive investigations, Robt. Hartig* advanced the idea that cambial awakening was dependent upon temperature and that therefore the thickness of the bark, temperature of the soil moisture, and insolation, were important factors. He found in an isolated Io-year old Pinus sylvestris, that cambial activity had begun two weeks earlier than in isolated 35- and 65-year old trees, and four weeks earlier than in a Ioo-year old tree grown under forest conditions. The comparisons were all made at a height of 6 meters. He also found that under natural forest conditions the growth of the annular ring of Scotch pine, Norway spruce, and European larch at a height of 27.5 meters, was on June 9 respectively 66 per cent, 56 per cent and 75 per cent completed. Going toward the base the growth decreased, and at a height of 1.5 meters the percentage of the annular ring completed was $35,2 \mathrm{I}$ and $\mathrm{I} 8$ per cent respectively. In isolated trees of Scotch pine and Norway spruce the growth on July 9 was approximately the same in all parts of the trunk. Under forest conditions growth was found to begin in the twigs and proceed downward, the cessation of growth following the same order.

According to Mer, $\uparrow$ the cambial activity in oak, beech, basswood, fir, and other trees of twenty-five years of age and under begins in the youngest twigs. In older trees cambial activity is described as simultaneous at the bases of the branches and trunk. He states also that in a single cross-section cambial activity may be evident on one side and not on another.

Hastings $\ddagger$ found that in broad-leaved trees increase in diameter did not begin until the buds had opened. He found that growth first begins in the I-year old twigs, and later it occurs in 2- and 3-year old twigs. When wood is forming in 5-or 6-year old growth there is simultaneous development over the entire tree. In pine it begins first in the 2- and 3-year old twigs. In the hemlock the growth was first observed in the 6-year old twigs,

* Hartig, R. Das Holz der deutschen Nadelwaldbäume, 35-38. I 885.

$\dagger$ Mer, E. Sur les causes de variation de la densité des bois. Bull. Soc. Bot. France 39: 95-105. I892.

$\ddagger$ Hastings, G. When increase in thickness begins in our trees. Science II. 12: 585 . 1900. 
while in Taxodium distichum the same conditions prevail as in the broad leaves.

Buckhout* made during a period of four years caliper measurements of European larch at intervals of five days during the growing season. The measurements were made at breast height and the age of trees experimented upon is given as 45 years. He found that the formation of leaves was coincident with the beginning of diameter increase. The beginning of this increase was close to April 25, during the four years. He found a gradual increase from this date until about July $\mathrm{r}$, when further growth in diameter practically ceased. The data secured from this method of measurement are not, as he himself realized, entirely conclusive, on account of the errors which may result from the swelling and shrinking of wood and bark with the varying moisture content.

From the horticultural side gross investigations have been made by Keffer, $\uparrow$ Goff, $\ddagger$ Cranefield, $\S$ and others on the duration of growth in fruit trees. Their work is concerned with the development of shoots and on the duration of wood increase as determined by the readiness with which the bark could be peeled. The work of these men will be considered in a subsequent paper.

\section{Methods of Investigation}

For the investigation during 1909, four larch trees of approximately thirteen years of age were used. These trees are hereafter designated for convenience as trees $A, B, C$, and $D$. The trees originally grew in a swamp in Oswego County, New York, but were transplanted in 1902 to the nursery on the Cornell University Campus, on land which slopes gently to the west and is of a welldrained, heavy clay soil type. The trees were planted four feet apart and were shaded on the east and west sides but not on the

* Buckhout, W. A. The formation of the annual ring of wood in European larch and the pine. Forestry Quarterly 5:259-267. I907.

$\dagger$ Keffer, C. A. The early growth and training of apple trees. Tenn. Agr. Exp. Sta. Bull. 14: I-I6. r9or.

$\ddagger$ Goff, E. S. The resumption of root growth in spring. Wisconsin Agr. Exp. Sta. Ann. Rep. 15: 220-228. 1898.

$\S$ Cranefield, F. Duration of growth period in trees. Wisconsin Agr. Exp. Sta. Ann. Rep. 17: 300-308. 1900. 


\section{Knudson: Cambium development of American Larch}

north or south. Trees $B, C$, and $D$ were very uniform as regards size and form. Tree $A$, although of the same age, was slightly smaller.

In order to determine the region of growth inception it was necessary to take material from the apex of the tree to the base. The larch has, at intervals, whorls of branches, the number of which agree approximately with the age of the tree. The trees used had each ten such whorls and material was removed from below each whorl, at different times throughout the growing season. Cuttings were made only from the south side of each tree. The first cuttings were made a few inches below each whorl of branches and the subsequent cuttings were made a few inches below the preceding and a little to one side. In obtaining the material for study two incisions, $2 \mathrm{~cm}$. apart, were made through the bark and into the wood to a depth of $\mathrm{I} \mathrm{cm}$. and the piece then removed with a small knife. The injured area was then filled with grafting wax.

The material collected from trees $A$ and $B$ was fixed in a solution consisting of 33 parts glycerine, 35 parts alcohol, 30 parts distilled water, and 2 parts glacial acetic acid. The material kept in this solution was in excellent condition for sectioning, though, of course, no good fixing of the protoplasmic structure was obtained. That collected from trees $C$ and $D$ was fixed in Gilson's solution and kept, by mistake, in 95 per cent alcohol. When attempts were made to section it, several months later, considerable difficulty was experienced, because of brittleness. Attempts to soften the material, by allowing it to remain in equal parts of glycerine and alcohol, and also in glycerine alone, proved futile. The greater part of the material was sectioned without imbedding, but some of it was necessarily imbedded in celloidin. The sections were cut from 20 to $40 \mu$ in thickness and stained with safranin and Delafield's haematoxylin of the formula so commonly used for wood staining. The methods employed during the season of I9I I are described subsequently.

\section{INVESTIGATIONS OF 1909}

The first cuttings were made on April I9 and at this time the buds located on the 4-, 5-, and 6-year old wood had opened, 
the leaves being $1 / 16$ of an inch in length. On the younger wood, the buds were less advanced. This was more marked in the I- and 2-year old wood. This slower development toward the terminal shoot and apex of the branch held true also for the catkins. The same condition was noted also in several larches which in September produced a new growth of leaves, the result of a drouth, followed by favorable conditions. This earlier development of leaves on the older wood is significant in the light of the subsequent facts concerning the inception of cambial activity.

Cambium in resting condition.-According to Sanio and other investigators the cambium proper consists of a tissue but one cell in thickness, which cells by division produce a row of xylem mother and a row of phloem mother cells. Each of these rows divides and gives rise respectively to two rows of potential xylem cells and two rows of potential phloem cells. Except by careful cytological study the row of true cambium cells cannot be distinguished from the neighboring cells. The term cambium has been, therefore, generally applied to that tissue which lies between the visibly differentiating phloem and xylem. The cambium tissue is composed of a number of rows of cells, which cells are characterized by their thin walls, dense protoplasmic content, and, viewed in cross section, rectangular shape. In trees in the resting condition it would be reasonably assumed that the true cambium comprises the first row of cells just without the xylem. The cells bordering this row on the outside would then be considered as phloem. As a matter of fact, however, sections made from cuttings obtained from the trunk of larch on November I 3 exhibit just outside of the xylem a distinct tissue $34 \mu$ in diameter, consisting of five or six rows of cells in thickness. The cells of the outer five rows are not visibly distinguished from cells of the inner row, but are distinguished from the adjacent phloem cells by their size and protoplasmic content. See FIG. I and 3. Because of the similarity of all of these cells I have considered the six rows as comprising the cambium tissue, the term cambium being employed in its generally applied sense.

Inception of cambial activity and development of phloem.-The material collected on April ig showed that cambial activity had begun. The layer of six cambium cells had increased in diameter. 
The outer cells of this tissue were losing their rectangular shape and assuming more nearly that of a square, as viewed in a cross section. See FIG. I, 2, and 3. In studying the slides made from material collected on April 19, it was found that in the 5th, 6th, and 7 th cuttings of tree $A$ the cambium had developed to a greater extent than in the other cuttings. Not only had the cambium increased in diameter, but seemingly new cells had been formed. This increased development near the middle was maintained until May 25. The average increase in number of phloem cells by May 25 was only I.8, but the diameter increase of the cambium and phloem was nearly roo per cent. Up to this time no xylem whatsoever had been developed. It appears therefore that the earliest growth consists in an enlargement of the cambium tissue with the gradual transformation of the peripheral cells into phloem tissue. The old phloem cells adjacent at this time are becoming compressed due to the pressure brought about by the transformation of the cambial cells. Compare FIG. I, 2, and 3 .

In TABLE $\mathrm{I}$ are given the figures obtained by the measurement of the diameter of phloem and cambium tissues in trees $A$ and $C$. The figures for the diameter of the cambium tissue during the resting period (cutting made November I3) are given for comparison. The figures included under the dates April 19 to May 25 inclusive refer to tree $A$. From June 3 to July 6 the figures refer to tree $C$.

As indicated previously, the six-celled layer adjacent to the xylem is considered the cambium. Although transformation of the peripheral cells had occurred, it is difficult to state which cells are cambium and which cells are phloem. Consequently the six rows, despite the transformation, I have considered as cambium. Any cells in excess of the six rows, which lie within the old compressed phloem cells, I have considered as new phloem. After May 25, when xylem and phloem were both developing rapidly, the cambium tissue was still considered as a tissue of six rows of cells. It was difficult to select always the six most uniform rows, but in general the error was slight and at most of little consequence.

From an examination of the table it may be seen that up to May 25 the middle regions show the greatest growth. From April I9 to May 25 the increase in phloem was gradual, but from May 25 
Knudson: Cambium development in American Larch 277

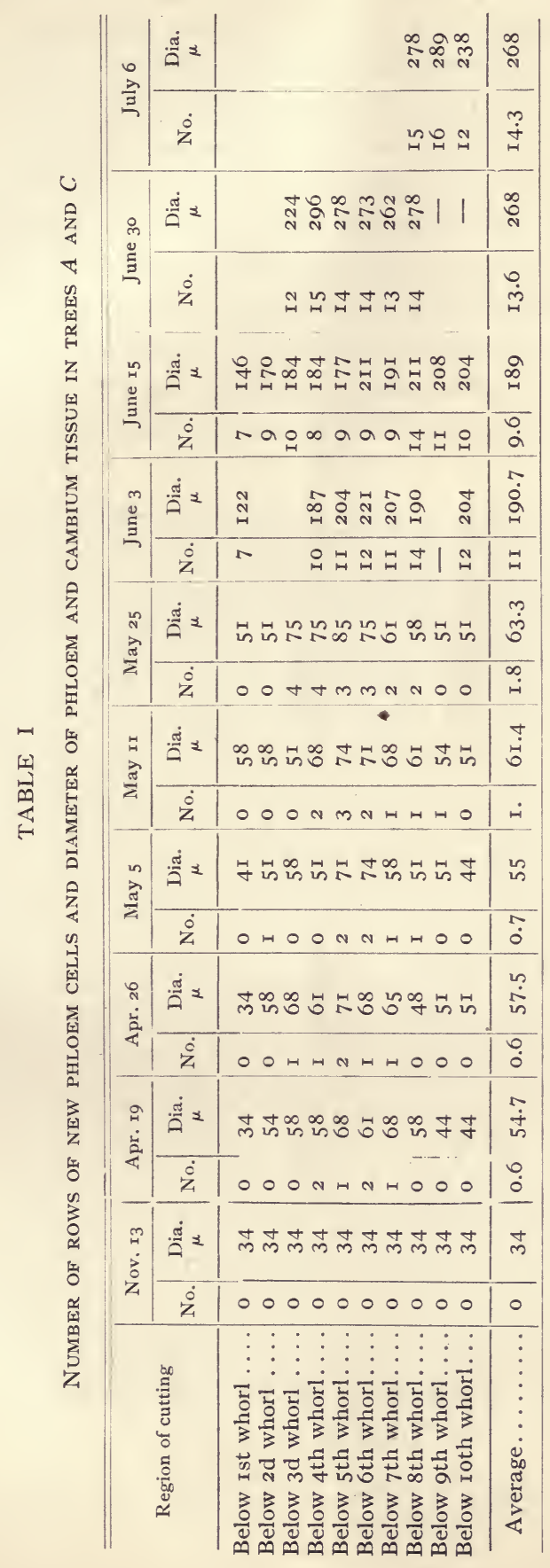


to June 3 the growth was markedly increased, while from June 3 to June 15 seemingly little growth occurred. After June 3 it appears that relatively few new phloem cells were formed, but growth consisted more of an enlargement of the cells already formed. Some of the figures for June 15 are less than the corresponding figures for June 3. This may be perhaps explained by the fact that the cuttings were made somewhat lower, or better perhaps by the fact that in obtaining these cuttings they were not taken on a line directly below the preceding, but to one side. Mer (loc. cit.) draws special attention to the well-known observation that wood growth is not always uniform on all sides of the tree.

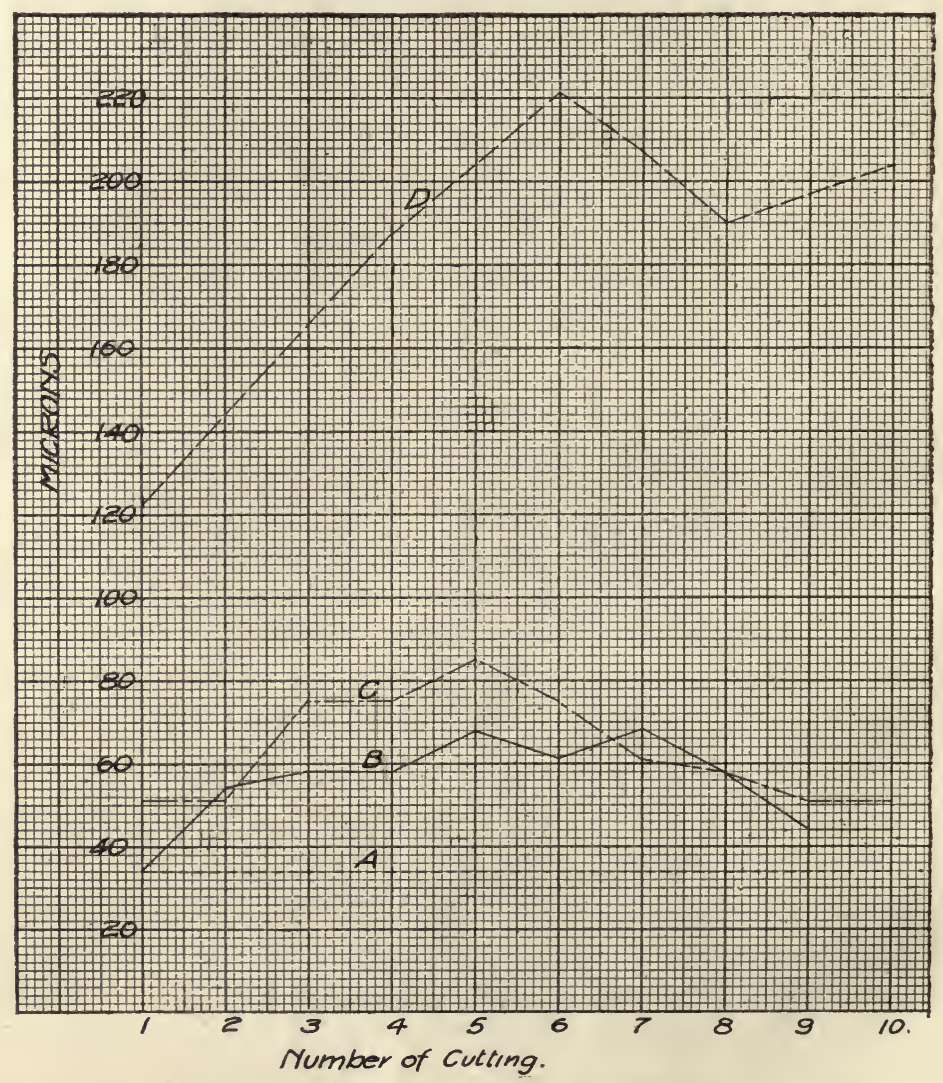

Diagram I. Diameter of cambium and new phloem at various different dates. $A$, Nov. 13; $B$, April 19; $C$, May 25; $D$, June 3 . 
By July 6 the phloem was nearly 'complete with respect to cell numbers; for, the average annual number of rows of phloem cells produced during a period of three years was found to be seventeen. At this time the cells were all very regular in form and no visible differentiation had occurred. In DIAGRAM I are represented the diameter measurements of the phloem at several different dates.

In trees $B$ and $D$ the growth is similar to that in trees $A$ and $C$, though more vigorous growth resulted in tree $B$ than in tree $A$. In this tree also the development of cambium consists first in a transformation of the peripheral cells. In this case, however, the number of rows of phloem cells produced by May 25 was 5.6 with nearly a 200 per cent increase in diameter. The detailed figures are given in TABLE II.

TABLE II

Number OF ROWS OF NEW PHLOEM CELlS AND DIAMETER OF PHLOEM AND CAMBI UM TISSUES IN TREES $B$ AND $D$

\begin{tabular}{|c|c|c|c|c|c|c|c|c|c|c|c|c|}
\hline \multirow[b]{2}{*}{ Region of cutting } & \multicolumn{2}{|c|}{ Nov. 13} & \multicolumn{2}{|c|}{ May 5} & \multicolumn{2}{|c|}{ May $x$} & \multicolumn{2}{|c|}{ May 25} & \multicolumn{2}{|c|}{ June 8} & \multicolumn{2}{|c|}{ June 18} \\
\hline & No. & $\underset{\mu}{\text { Dia. }}$ & No. & $\underset{\mu}{\text { Dia. }}$ & No. & $\underset{\mu}{\text { Dia. }}$ & No. & $\underset{\mu}{\text { Dia. }}$ & No. & $\underset{\mu}{\text { Dia. }}$ & No. & $\underset{\mu}{\text { Dia. }}$ \\
\hline Below Ist whorl..... & 0 & 34 & - & & - & 75 & 2 & 68 & 8 & I70 & II & 228 \\
\hline Below 2d whorl. & 0 & 34 & 0 & 34 & 3 & 58 & 4 & 122 & II & I93 & II & 2 I 8 \\
\hline Below 3d whorl. & 0 & 34 & 3 & 68 & 4 & 82 & 4 & 76 & - & - & II & 286 \\
\hline Below 4th whorl..... & 0 & 34 & 4 & 102 & 4 & 102 & 6 & 92 & I 2 & $22 \mathrm{I}$ & I4 & \\
\hline Below 5 th whorl..... & 0 & 34 & 5 & 85 & 6 & II 5 & - & - & 一 & 一 & I 2 & 262 \\
\hline Below 6th whorl. & 0 & 34 & 4 & 68 & 8 & 107 & 7 & 92 & Io & I90 & I3 & 238 \\
\hline Below 7 th whorl.. & 0 & 34 & - & - & 4 & 85 & 7 & 102 & - & - & I4 & 279 \\
\hline Below 8 th $x$ & 0 & 34 & 4 & 85 & - & - & 6 & 92 & 8 & I 70 & - & \\
\hline Below 9th whorl... & 0 & 34 & 2 & $6 I$ & - & - & 6 & 76 & 8 & I73 & I 2 & 245 \\
\hline Below Ioth whorl.. & 0 & 34 & 3 & 75 & 一 & 一 & 6 & - & 一 & 一 & I I & 238 \\
\hline Average. & 0 & 34 & 3.1 & 72 & 4.8 & 89 & 5.3 & 90 & 9.5 & I86 & I 2 & 250 \\
\hline
\end{tabular}

Development of xylem.-While in tree $A$ there was a gradual increase in phloem from April I9 to May 25, yet no xylem cells had been formed. During the week of May 25 to June 3, coincident with the marked increase of phloem, a very marked increase of xylem occurred, over one third of the xylem being completed during these seven days. TABLE III gives the figures obtained for the number of rows of xylem cells formed, and the diameter of the xylem tissue in the various cuttings at the different dates. There is included also the diameter of the xylem tissue formed in tree $B$ during the years 1909 and I9ro. In the first column the 
figures refer to tree $A$. The figures from June 3 to July 6 refer to tree $C$.

\author{
TABLE III
}

NUMBER OF ROWS OF NEW XYLEM CELLS FORMED AND DIAMETER OF NEW XYLEM tissue in tREes $A$ AND $C$

\begin{tabular}{|c|c|c|c|c|c|c|c|c|c|c|c|}
\hline \multirow[b]{2}{*}{ Region of cutting } & \multirow{2}{*}{$\frac{\text { May 25 }}{\text { No. }}$} & \multicolumn{2}{|c|}{ June 3} & \multicolumn{2}{|c|}{ June 15} & \multicolumn{2}{|c|}{ June $3^{\circ}$} & \multicolumn{2}{|c|}{ July 6} & \multirow{2}{*}{$\begin{array}{c}1909 \\
\begin{array}{c}\text { Dia. } \\
\mu\end{array}\end{array}$} & \multirow{2}{*}{$\frac{\text { rgro }}{\underset{\mu}{\text { Dia. }}}$} \\
\hline & & No. & $\underset{\mu}{\text { Dia. }}$ & No. & $\underset{\mu}{\text { Dia. }}$ & No. & $\underset{\mu}{\text { Dia. }}$ & No. & $\underset{\mu}{\text { Dia. }}$ & & \\
\hline Below Ist whorl. & 0 & I5 & 262 & 25 & 544 & 43 & $\mathrm{I}, 054$ & & & 646 & 986 \\
\hline Below 2d whorl & 0 & & & 33 & 833 & 55 & 1,564 & & & $\mathrm{I}, 598$ & $x, 377$ \\
\hline Below 3 d whorl. & 0 & 20 & 578 & 33 & 918 & 48 & $|\mathrm{I}, 462|$ & & & $\mathrm{I}, 853$ & 1,87 \\
\hline Below 4 th whorl. & 0 & 29 & 697 & 43 & $\mathrm{I}, \mathrm{I} 22$ & 50 & $\mathrm{I}, 462$ & & & 1,785 & 1,8 \\
\hline Below 5th whorl. & o & 28 & 748 & 45 & $I, 292$ & 55 & $\mathrm{I}, 530$ & & & $I, 360$ & 1,955 \\
\hline Below 6th whorl. & 0 & 23 & 646 & 46 & 1,326 & $5^{8}$ & $\mathrm{I}, 666$ & & & $I, 275$ & $I, 224$ \\
\hline Below 7 th whorl.. & 0 & 24 & 648 & 36 & I, I 22 & 57 & I, 5 I 5 & & & $\mathrm{I}, 734$ & 1,428 \\
\hline Belew 8th whorl.. & 0 & 22 & 714 & 36 & $\mathrm{I}, \mathrm{I} 56$ & 57 & 1,632 & 65 & 1,972 & 2,363 & I, 598 \\
\hline Below 9th whorl.. & 0 & - & 697 & 28 & 850 & & - & 62 & $\mathrm{I}, 870$ & 1,666 & $\mathrm{I}, 088$ \\
\hline Below Ioth whorl. & 0 & 20 & 663 & 27 & 833 & $5^{8}$ & $\mathrm{I}, 564$ & 58 & $\mathrm{I}, 802$ & - & - \\
\hline Average.. & 0 & 22.5 & 628 & 35.2 & 999.6 & $53 \cdot 3$ & I, 493 & 6г.6 & $\mathrm{I}, 88 \mathrm{I}$ & I,, 586 & 1,488 \\
\hline
\end{tabular}

From the table it cannot be determined exactly in which part of the tree xylem growth first begins. The greatest growth by June 3 was below the fifth whorl of branches while the least growth was just below the first whorl of branches. In general, by June 3 more xylem cells were formed in the middle of the tree than at either the top or base. This would tend to indicate that the first growth of xylem occurred in the middle of the tree below the fifth whorl of branches.

TABLE IV

NuMber OF ROWS OF NEW XYLEM CELLS AND DIAMETER OF NEW XYLEM TISSUE IN TREES $B$ AND $D$

\begin{tabular}{|c|c|c|c|c|c|c|c|}
\hline \multirow{2}{*}{ Region of cutting } & \multirow{2}{*}{$\frac{\text { May II }}{\text { No. }}$} & \multicolumn{2}{|c|}{ May 25} & \multicolumn{2}{|c|}{ June 8} & \multicolumn{2}{|c|}{ June 18} \\
\hline & & No & $\underset{\mu}{\text { Dia. }}$ & No. & $\underset{\mu}{\text { Dia. }}$ & No. & $\underset{\mu}{\text { Dia. }}$ \\
\hline Below Ist whorl. & 0 & 0 & 0 & 22 & 442 & 43 & 1,003 \\
\hline Below $2 \mathrm{~d}$ w & 0 & 0 & 0 & 40 & 647 & 53 & 1,326 \\
\hline w 3 d whorl. . & 0 & 0 & o & - & - & 55 & I,394 \\
\hline Below 4 th whorl $\ldots \ldots \ldots \ldots$ & 0 & 4 & $5 \mathrm{I}$ & 35 & 918 & 50 & $\mathrm{I}, 258$ \\
\hline Below 5th & 0 & - & - & 一 & - & 45 & 1,292 \\
\hline ........ & 0 & 5 & 55 & 32 & 850 & 46 & $\mathrm{I}, \mathrm{I} 22$ \\
\hline 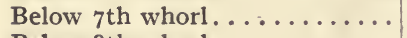 & 0 & 2 & 20 & - & - & 55 & 1,258 \\
\hline Below 8th & 0 & 0 & 0 & 34 & 850 & - & - \\
\hline Below 9th w & 0 & 0 & 0 & 30 & 782 & 50 & 1,292 \\
\hline Below Ioth whorl. ........... & 0 & 0 & o & & 一 & 49 & 1,292 \\
\hline Average $\ldots \ldots \ldots \ldots \ldots \ldots$ & 0 & I. 2 & I4 & 32 & 748 & 49 & 1,248 \\
\hline
\end{tabular}


Knudson: Cambium development in American Larch 281

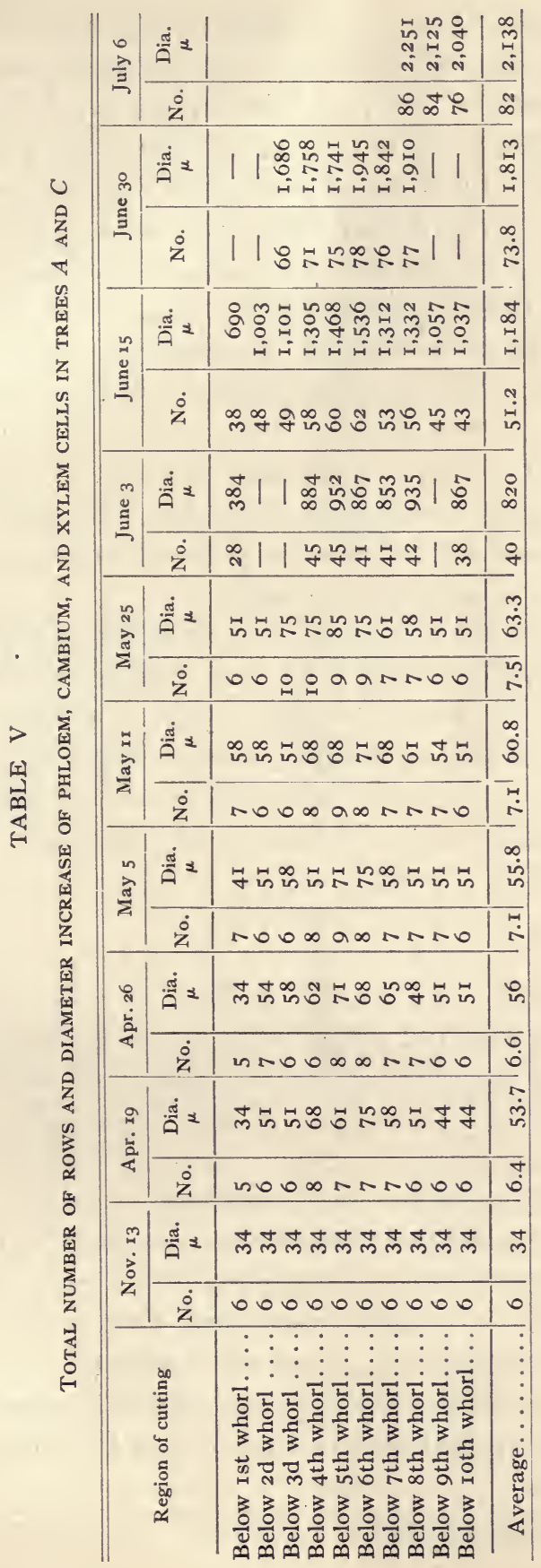


While in trees $A$ and $C$ the region of the first growth of xylem could not be definitely located, more fortunate results were obtained with tree $B$. No xylem was formed in tree $B$ until May 25 and then neither at the top nor at the base of the trunk, but in the middle region. By May 25 then the xylem in that part of the tree between the fourth and fifth whorls of branches was four cells in thickness,-while between the sixth and seventh whorls it was five cells and between the seventh and eighth it was two cells in diameter. The most màrked development again occurred immediately after May 25. The detailed figures are given in TABLE IV.

Season and duration of diameter increase.-In order to bring out more clearly the period of greatest diameter increase, the combined values for increase of phloem, cambium, and xylem, in trees $A$ and $C$ are given in TABLE v.

From the table it is at once evident that very little growth took place previous to May 25, and the growth which occurred was confined, as before indicated, entirely to the cambium and phloem. From May 25 to June 3 a very marked increase occurred, and during that time in the middle regions of the trunk nearly one half of the total diameter increase was completed. In TABLE VI is given the daily average increase in rows of cells and also the daily diameter increase in trees $A$ and $C$.

TABLE VI

\begin{tabular}{|c|c|c|c|c|}
\hline Period & May 25-June 3 & June 3 -June ${ }_{5}$ & June $x_{5}$-June 30 & June $30-J u l y$ 6* \\
\hline $\begin{array}{l}\text { No. rows of cells......... } \\
\text { Dia. in microns......... }\end{array}$ & $\begin{array}{r}4.2 \\
94.5\end{array}$ & $\begin{aligned} \text { I. } & \text { ( } \\
30 . & \end{aligned}$ & $\begin{array}{l}1.4 \\
40 .\end{array}$ & $\begin{aligned} I . \\
48 .\end{aligned}$ \\
\hline
\end{tabular}

By July 6 the ring of xylem was almost complete, judging from the extent of the summer wood which was then in the process of formation, though not yet completely developed. Unfortunately no further series of cuttings were made after July 6 to determine the succession with regard to growth cessation.

In TABLE VII is given the combined diameters of the phloem, cambium, and xylem tissue in trees $B$ and $D$, as well as the total number of cells.

\footnotetext{
* For cutting nos. 9-1o only.
} 
Knudson: Cambium development in American Larch 283

TABLE VII

TOTAL NUMBER OF NEW ROWS AND DIAMETER OF PHLOEM, CAMBIUM AND XYLEM CELLS IN TREES $B$ AND $D$

\begin{tabular}{|c|c|c|c|c|c|c|c|c|c|c|c|c|}
\hline \multirow[b]{2}{*}{ Region of cutting } & \multicolumn{2}{|c|}{ Nov. $x_{3}$} & \multicolumn{2}{|c|}{ May 5} & \multicolumn{2}{|c|}{ | May II } & \multicolumn{2}{|c|}{ May 25} & \multicolumn{2}{|c|}{ June 8} & \multicolumn{2}{|c|}{ June 18} \\
\hline & No. & $\underset{\mu}{\text { Dia. }}$ & No. & $\underset{\mu}{\text { Dia. }}$ & No. & $\begin{array}{c}\text { Dia. } \\
\mu\end{array}$ & No. & $\underset{\mu}{\text { Dia. }}$ & No. & $\underset{\mu}{\text { Dia. }}$ & No. & $\underset{\mu}{\text { Dia. }}$ \\
\hline Below Ist whorl. & 6 & 34 & - & - & Io & 75 & 8 & 68 & 36 & 612 & 60 & $\mathrm{I}, 23 \mathrm{I}$ \\
\hline Bel & 6 & 34 & 6 & 34 & 9 & 58 & II & 89 & 57 & 840 & 70 & $\mathrm{I}, 544$ \\
\hline Below 3d v & 6 & 34 & 9 & 68 & Io & 88 & Io & 75 & 一 & - & 72 & 1,680 \\
\hline Below 4 th whorl. . & 6 & 34 & I0 & 102 & Io & 102 & 16 & I 43 & 53 & $\mathrm{I}, 07 \mathrm{I}$ & 70 & 1,520 \\
\hline Below 5t & 6 & 34 & II & 85 & I4 & I I 5 & - & - & & - & 63 & $I, 486$ \\
\hline Below $6 \mathrm{t}$ & 6 & 34 & IO & 68 & I5 & 108 & I 8 & $\mathrm{r} 47$ & 48 & $\mathrm{I}, \mathbf{0 4 0}$ & 65 & 1,506 \\
\hline Below 7 th & 6 & 34 & - & - & II & 85 & I4 & 122 & - & - & 77 & $\mathrm{I}, 537$ \\
\hline Below 8th & 6 & 34 & I0 & 85 & - & - & 12 & 92 & 48 & 986 & - & 一 \\
\hline Below 9th & 6 & 34 & 8 & $6 I$ & - & - & I 2 & 76 & 44 & 955 & 68 & $\mathrm{I}, 537$ \\
\hline Below Ioth whorl.. & 6 & 34 & 9 & 75 & - & - & - & - & - & - & 62 & $\mathrm{I}, 53^{\circ}$ \\
\hline Average & 6 & 34 & 9 & 72 & I I & 90 & 12.6 & IOI.5 & $47 \cdot 5$ & 917 & 69.4 & I, 508 \\
\hline
\end{tabular}

The season of diameter growth in larch is relatively short. Practically all of the growth occurred during the month of June. The small increase produced from the time of bud opening, April I9 to May 25, consisted entirely of cambium and phloem development. The diameter increases of trees $A$ and $C$ and $B$ and $D$ during the season 1909 are graphically represented in DIAGRAM II.

\section{INVESTIGATION OF I9I I}

Since the studies made in 1909 indicated that growth in diameter first occurred in the middle region of the trunk and not at the base or apex, it seemed advisable to continue these studies with respect to the development in the lateral branches. The investigation was made with the object of answering the three following questions: (I) Does inception of diameter increase begin first in the topmost branches, in the middle, or in the basal, branches? (2) In what part of the individual branches does diameter increase begin? (3) Does xylem development in the lateral branches precede that in the trunk?

For this investigation a larch tree of approximately to years of age was used. It was growing isolated, about roo feet from the trees mentioned above, growing in the nursery row. For convenience this tree is hereafter designated as tree $E$. On May 22, from each of the whorls of branches from apex to base, one branch 


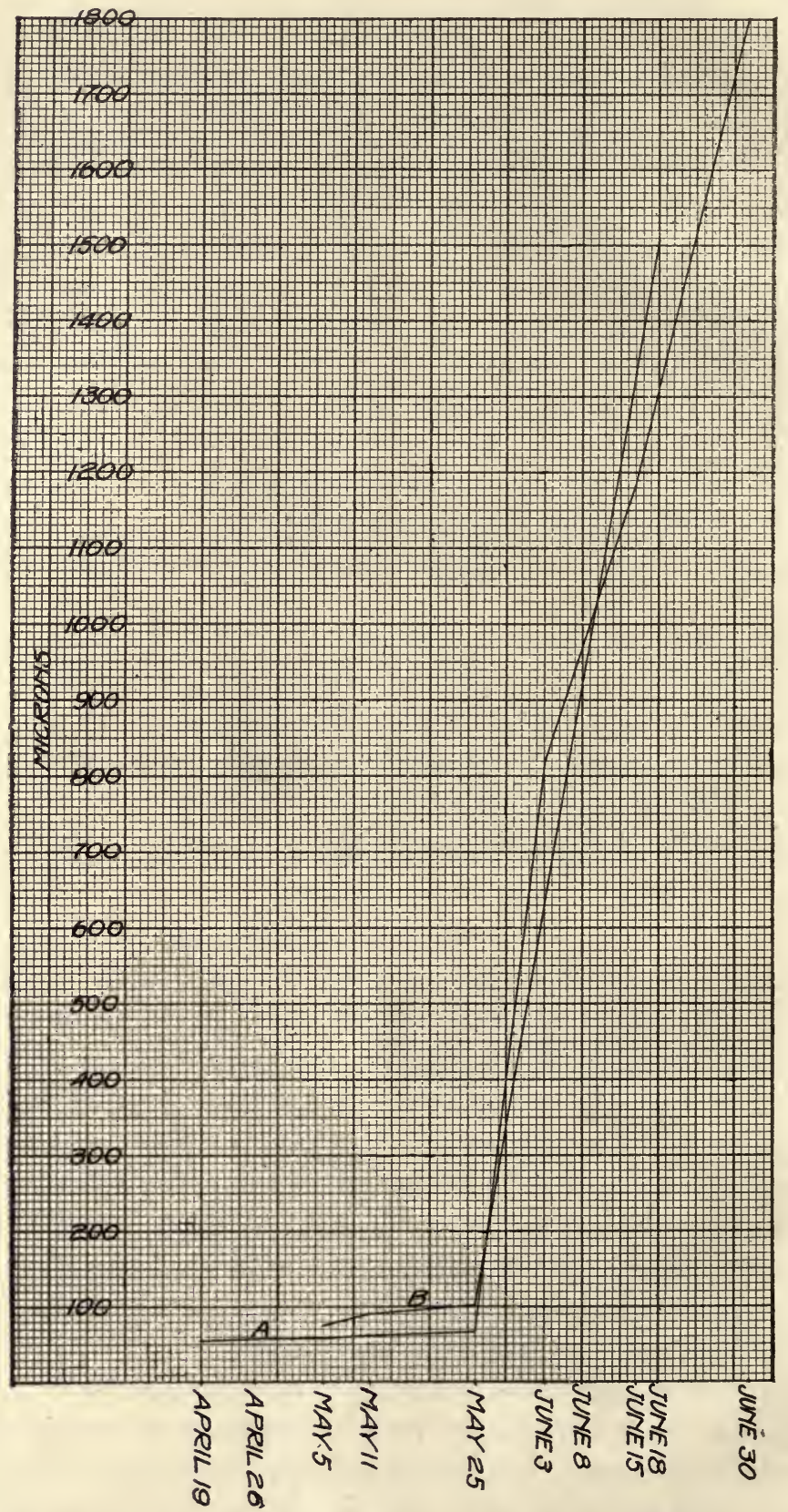

Diagram II. $A$, diameter increase in trees $A$ and $C ; B$, diameter increase in trees $C$ and $D$. 
was removed. The removal, as before, was made from the south side of the tree. The branches were numbered according to their position on the tree, the topmost branch being No. I, and the basal branch No. 7. From the individual branches there was removed from each season's growth a cutting; from the topmost branch two such cuttings were removed and from the basal branch

TABLE VIII

Number of ROWS OF XYLEM CELLS AND DIAMETER INCREASE OF XYLEM TISSUE IN THE CUTTING FROM LATERAL BRANCHES OF TREE $E$

\begin{tabular}{|c|c|c|c|}
\hline No. of branch & $\begin{array}{c}\text { Region of cutting on lateral } \\
\text { branch }\end{array}$ & $\begin{array}{l}\text { No. of rows of new } \\
\text { xylem cells }\end{array}$ & $\begin{array}{l}\text { Diameter increase } \\
\text { of xylem }\end{array}$ \\
\hline I & Below Ist whorl & 0 & $0\}$ \\
\hline I & Below 2d whorl & 0 & of \\
\hline 2 & Below Ist whorl & o & 0 \\
\hline 2 & Below 2d whorl & 0 & 0 \\
\hline 2 & Below 3d whorl & 0 & of \\
\hline 3 & Below Ist whorl & 2 & $37 \mu$ \\
\hline 3 & Below 2d whorl & 2 & $37 \mu$ \\
\hline 3 & Below 3d whorl & 0 & 0 \\
\hline 3 & Below 4th whorl & o & 0 \\
\hline 4 & Below Ist whorl & 2 & $37 \mu$ \\
\hline 4 & Below 2d whorl & I & $18 \mu$ \\
\hline 4 & Below 3d whorl & 2 & $37 \mu$ \\
\hline 4 & Below 4th whorl & o & 0 \\
\hline 5 & Below Ist whorl & 2 & $29.6 \mu$ \\
\hline 5 & Below 2d whorl & I & I8 $\mu$ \\
\hline 5 & Below 3d whorl & o & 0 \\
\hline 5 & Below 4th whorl & 2 & $37 \mu$ \\
\hline 5 & Below 5th whorl & o & 0 \\
\hline 5 & Below 6th whorl & o & 0 \\
\hline 6 & Below Ist whorl & 2 & $37 \mu$ \\
\hline 6 & Below 2d whorl & o & 0 \\
\hline 6 & Below 3d whorl & o & 0 \\
\hline 6 & Below 4 th whorl & I & I $8 \mu$ \\
\hline 6 & Below 5th whorl. & 2 & $37 \mu$ \\
\hline 6 & Below 6th whorl & o & 0 \\
\hline 6 & Below 7 th whorl & 2 & I $8 \mu$ \\
\hline 7 & Below Ist whorl & o & 0 \\
\hline 7 & Below 2d whorl & o & 0 \\
\hline 7 & Below 3d whorl & I & I $8 \mu$ \\
\hline 7 & Below 4 th whorl & 0 & 0 \\
\hline 7 & Below 5th whorl & I & I $8 \mu$ \\
\hline 7 & . Below 6th whorl & 0 & 0 \\
\hline 7 & Below 7 th whorl & o & 0 \\
\hline 7 & Below 8th whorl & o & 0 \\
\hline
\end{tabular}

seven cuttings. These cuttings were fixed, sectioned, and prepared as before. In the following table the figures given refer only to the number of cells in the new xylem layer and to the diameter of that tissue. The diameter increase over the entire tree is represented in DIAGRAM III. 
In order to show more clearly the results obtained and to aid in the interpretation the following two tables have been compiled from the preceding. In the TABLE IX are presented for each of the branches the average number of rows of xylem cells and the average diameter increase of the xylem tissue for the entire lateral branch. The averages are obtained from the figures for each individual cutting.

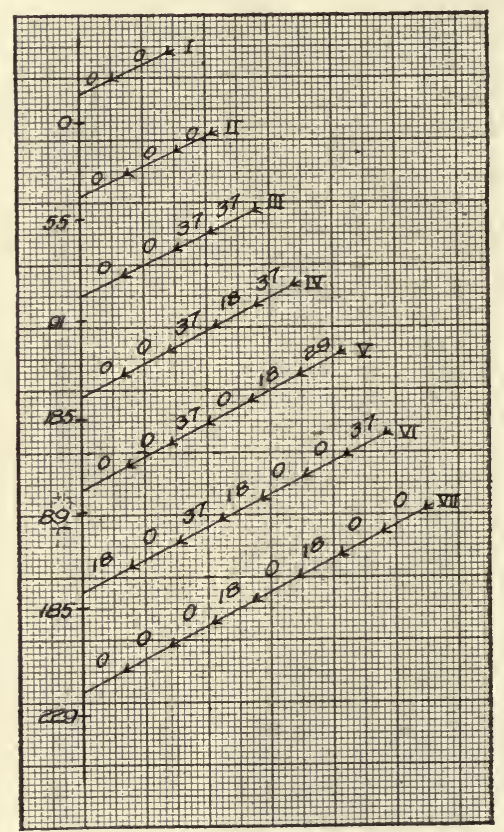

Diagram III. Diameter increase of xylem in various parts of tree $E$ on May 22

TABLE IX

AVERAGE DIAMETER INCREASE OF XYLEM IN LATERAL BRANCHES

Branch

xylem cells

I. . . . . . . . . . . . . . o

II ...................

III . . . . . . . . . . . . I

IV $\ldots \ldots \ldots \ldots \ldots \ldots \ldots \ldots$ I.25

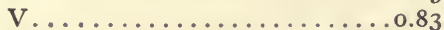

VI. . . . . . . . . . . . . I

VII. . . . . . . . . . . . . 25
Average diameter increase of xylem

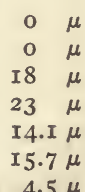

I. $5.7 \mu$

From the above table it is evident that the least growth occurred in the top and basal branches and the greatest growth 
in the middle branches. This increase corresponds with the results secured previously on the diameter increase in the trunk, in which it was found that the growth first began in the middle region.

In regard to the second question as to the region of the branch in which growth first occurs, TABLE $\mathrm{X}$ is suggestive. The figures of the following table are the averages of the seven apical cuttings, the seven basal cuttings and the average diameter of xylem in the middle regions of the seven branches.

TABLE $\mathrm{X}$

AVERAGE DIAMETER INCREASE OF XYLEM AT APEX, MIDDLE, AND BASE OF ALL LATERAL BRANCHES

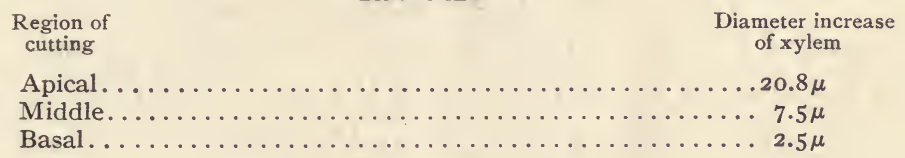

From previous results it was expected that the growth would first occur in the middle of the branch, but the evidence indicates that the development of xylem in the lateral branches begins at the apex and then continues towards the base. The opening of the buds, however, does not follow the same order. On April 26, I9II, the lateral branches of a tree in the nursery row were examined and it was found that buds on the one and two years old wood had not yet opened, on the third year wood the leaves were just protruding while on the older wood the buds were fully opened.

In regard to the third question, "Does diameter increase in the twigs and branches precede that in the trunk?" the following observations were made. From the same tree from which the cuttings from the lateral branches were removed and on the same day,-namely, May 22, cuttings were removed from the apex to the base of the trunk. Seven such cuttings were removed from the south side of the tree, one cutting just below each whorl of branches. From a study of slides prepared from the material the following figures have been obtained. (See TABLE XI.) There are also included in TABLE XI figures derived from cuttings made on June 6.

A comparison of the figures for May 22 with the figures for growth in the lateral branches (see DIAGRAM III) reveals the fact 
288 Knudson: Cambium development in American Larch

TABLE XI

Number of rows of XYlem cells aNd diameter increase of Xylem in tree $E$

\begin{tabular}{|c|c|c|c|c|}
\hline Region of cutting & No. May 22 & $\begin{array}{c}\text { Diameter increase of } \\
\text { xylem May } 22\end{array}$ & No. June 6 & $\begin{array}{l}\text { Diameter increase of } \\
\text { xylem June } 6\end{array}$ \\
\hline Below Ist whorl.. & o & 0 & - & - \\
\hline Below 2d whorl. & 3 & $55.5 \mu$ & 5 & III $\mu$ \\
\hline Below 3d whorl. & 5 & 9I $\mu$ & 7 & I $39.5 \mu$ \\
\hline Below 4th whorl... & 7 & $185 \mu$ & & \\
\hline Below 5th whorl... & 4 & $88.8 \mu$ & 9 & 259 \\
\hline Below 6th whorl... & 7 & $185 \mu$ & I 7 & 444 \\
\hline Below 7 th whorl... & 9 & $229.4 \mu$ & 20 & $48 x$ \\
\hline Average $\ldots \ldots \ldots \ldots$ & 5.8 & І39 $\mu$ & 9.8 & 286 \\
\hline
\end{tabular}

that except for the apical part of the trunk the growth there has been much greater than in the branches. The average diameter increase of xylem in all the branches was by May 22 only $10.7 \mu$, and the average number of cells in the new xylem layer only 0.62 . The greatest diameter increase in the brançhes was only $37 \mu$, while the average for the trunk was 5.8 cells with a diameter of $139 \mu$. If reference is made to TABLE VIII it will be seen that no growth occurred in branch No. 2 while in the trunk at this region the increase was $55.5 \mu$. The average diameter of xylem in branch No. 7 was only $4-5 \mu$, while in the region of the trunk from which the branch was secured the diameter increase amounted to $229 \mu$. It is very evident, therefore, that in a larch of this age under isolated conditions growth does not begin first in the twigs and then extend to the trunk, but rather it begins first in the trunk.

The figures in TABLE XI give no strong indication of the region in which growth first began. The diameter increase was greatest just below the 4 th, 6 th, and 7 th whorls of branches. No increase was manifest near the apex.

\section{TABLE XII}

Region of cutting in trunk

No. of rows of xylem cells

Dia. increase of xylem

Below Ist whorl. . . . . . . Cutting lost

Below 5th whorl.......... 4

Below 7 th whorl.......... 9

Below gth whorl......... 5

III $\mu$

$222 \mu$ I29 $\mu$

In order further to check the work of 1909 a few cuttings were made from another tree in the nursery row on May 22. This tree 
was now approximately 15 years of age. Cuttings were removed from the south side of the trunk below the Ist, $5^{\text {th, }} 7$ th, and 9th whorls of branches. The results from the measurement of the xylem are found in TABLE XII.

While no conclusions can be drawn respecting the inception of growth the indications again point to the middle region. The figures are of interest mainly because of the fact that growth of xylem has occurred before May 25, which was the date of xylem development in 1909 .

\section{FACTORS INFLUENCING DATE OF XYLEM FORMATION}

Temperature, moisture, and insolation are important factors in all growth phenomena. In I909 and I9I I the opening of buds of larch began April 19. In 1909 the xylem formation began on May 25, while in I9I I the xylem formation began about May 20.* The temperature, moisture, and sunshine figures for the intervals between the bud opening and wood formation are found in the following table. The mean temperature for the day is considered as the number of heat units for that day, and the total heat units $\dagger$ is considered as the sum of these mean temperatures.

\begin{tabular}{c|c|c|c}
\hline \hline Period & Total heat units & Hours of sunshine & Precipitation \\
\cline { 2 - 4 } April 19-May 25, I909... & I,810 & $\begin{array}{l}234.5 \\
257 .\end{array}$ & $\begin{array}{l}2.89 \\
2.00\end{array}$ \\
\hline
\end{tabular}

The number of heat units then during the interval before wood formation in I9I I was almost as great as that during the longer period of 1909, while the amount of sunshine was greater during the I9I I period. The amount of precipitation at this time of the year was not important as sufficient water was available both seasons. In I9II, however, the mean temperature for the three days preceding wood formation ranged from $76^{\circ} \mathrm{F} .-78^{\circ} \mathrm{F}$. and for the three days preceding this period the range of the mean temperatures was $62^{\circ} \mathrm{F} .-69^{\circ} \mathrm{F}$. During 1909 the nine days preceding wood formation ranged in mean temperature from $50^{\circ} \mathrm{F} .-54^{\circ} \mathrm{F}$. except one day which had a mean temperature of 58 . The three

* The exact date of xylem formation was not determined. The observation on May 22 showed a diameter increase of 6 cells.

$\dagger$ No daily mean temperature was below $34^{\circ} \mathrm{F}$. 
days preceding wood formation in 1909 had 39.4 hours of sunshine; the same period in I9I I had 26.2 hours of sunshine. It is very probable therefore that during I9II the relatively higher temperature for the six days preceding wood formation was important in hastening the inception of xylem formation.

\section{SUMMARY}

Results of 1909. (I) Cambium and phloem development.The cambium in the trunk during the resting condition consists of six rows of cells $34 \mu$ diameter. On April I9 the first material collected exhibited an increase in diameter of the cambium tissue. The cambium cells were all enlarged while the outer cells were in the process of transformation, changing from a rectangular to square shape as viewed in cross section. In the middle regions of the trunk on April I9 an increase in phloem cells was evident. The increase of cambium and phloem was gradual over the entire trunk in tree $A$ up to May 25, the greatest increase being maintained in the middle region. Similar conditions were found in tree $B$, though here the increase of new phloem cells was more marked. The greatest growth of phloem occurred immediately after May 25 and was coincident with the greatest development of xylem.

(2) Xylem development.--In tree $A$ no xylem was formed before May 25. In tree $B$ a few xylem cells were formed by May 25 in the middle regions of the trunk. Growth of xylem was almost simultaneous, however, in all parts of the trunk. The greatest growth occurred immediately after May 25 and in tree $C$ the xylem was nearing completion by July 6 .

REsults of I9II.-(I) Growth in diameter in the lateral branches begins first in the middle branches and is followed by that in the basal and apical branches.

(2) In the individual branches growth begins first at the apex and then descends towards the base.

(3) Diameter increase of the trunk precedes that in the branches and twigs.

(4) Temperature and insolation conditions in I9II induced wood formation five days earlier than in 1909.

(5) No direct evidence was secured in I9I I concerning the 
Knudson: Cambium development in American Larch 291

region in the trunk of first cambial activity. Indications pointed again to the middle and basal regions.

\section{Discussion of Results}

In a number of anatomical text books it is stated that the xylem development precedes that of the phloem. This idea is conveyed rather ambiguously by Stevens.* In the American larch the development of phloem certainly precedes that of xylem and its most rapid development is coincident with that of the xylem. Brown's $\dagger$ figures indicate that in Pinus rigida a similar condition prevails.

The results obtained by the writer do not agree with those of Th. Hartig $\ddagger$ with 30-year old European larch, wherein diameter increase near the base of the trunk was two to four weeks later than that in the twigs and branches. The factors which may operate to cause this difference are considered subsequently. My results agree with those of Brown§ who finds that in Pinus rigida the first diameter increase of xylem begins a few meters below the apex. The work of Brown was done during the same period as that of the writer and on trees in a plot adjacent to those used in this investigation.

Respecting the date of diameter increase Buckhout states that in European larch it is coincident with leaf formation. It is very probable that the diameter increase at this time is due mainly to a swelling of the tissues. In my investigations the development of xylem began a month later than the beginning of leaf formation. From observations made during the past two years with a considerable number of trees and from the results of other investigators it seems probable that in general growth in diameter does not begin until the leaves have been fully developed and have been sufficiently active in food making to supply the requirements of rapid cell formation. The reserve foods stored up in the fall are probably largely utilized in leaf and also in blossom formation, when the latter precede the formation of leaves.

* Stevens, W. C. Plant anatomy, 2nd Ed., p. I7o. I9ro.

† Brown, H. P. Growth studies in forest trees, I. Pinus rigida Mill. Bot. Gaz.

54:386-402. I9I2.

$\ddagger$ Hartig, T., loc. cit.

§ Brown, H. P., loc. cit. 


\section{Knudson: Cambium development in American Larch}

What factors operate to cause growth inception in a particular part of a tree? Robt. Hartig* believed that temperature was the most important factor, consequently insolation, temperature of the air and of the soil moisture, and thickness of the bark are the essential factors which determine the region of first diameter increase. No doubt these factors are important, as considerable evidence indicates that in old trees diameter increase is delayed at the base of trunk where insolation is poor and the bark is thick. In young trees, however, these are not the only factors. In the larch trees of 13 years of age the diameter increase did not begin first in those regions with the thinnest bark and best insolation. The thickness of the bark at the apex, middle and base of the tree $A$ was respectively $596 \mu, \mathbf{I}, 937 \mu$, and $3,278 \mu$. So also in the isolated tree $E$ the inception of diameter increase did not occur in the parts of the tree best insolated and with the thinnest bark, but rather in the thicker barked and more poorly insolated parts of the tree, namely the middle and basal regions of the trunk. In the individual branches, however, growth in diameter began in the regions of thinnest bark and of best insolation.

Whitten $\dagger$ has shown that the color of the bark may be important in the time of growth inception of buds. The color of the bark may be a factor in determining the region of diameter increase in young trees of larch. The color of the bark of the apical part of the trunk in spring is yellowish to greenish, becoming darker towards the base. The darker color, because of its capacity for heat absorption, may counteract the insulating effect of the thick bark, consequently the diameter increase begins in the basal and middle regions. The growth begins first in the middle regions because the bark here is of the same color as that of the basal regions and is only about half as thick. The fact that in the branches and twigs of larch the opening of buds on the apical regions is retarded is suggestive of the influence of the color of the bark. The bark of the apical regions being of lighter color less heat is absorbed, its temperature therefore is lower and the development of the buds is slower. This is in agreement with the

* Hartig, R., loc. cit.

$\dagger$ Whitten, J. C. Winter protection of the peach. Missouri Agr. Exp. Sta. Bull. 38: 140-164. 1897 . 
results obtained by Whitten* on the date of blossoming of greenand purple-twigged peach trees.

The temperature of the soil moisture and of the air, and the thickness and color of the bark are not the only factors operative in inducing diameter increase. Certainly as regards all of the above factors the branches are all more favored than the trunk of the tree, yet in the isolated tree $E$ the diameter increase began first in the trunk. Food supply may be a factor in stimulating the cambium of the trunk to diameter increase, before there is development in the branches. It is not possible to state the influence of food supply. Controlled experimental work with this as well as with the other factors is necessary to give an idea of the influence of each in stimulating the cambium to activity.

In conclusion it should be stated that considerably more work is necessary in order to establish the region of the tree in which cambium activity first begins. No doubt different conditions will be found for trees of the same species of different ages, and for trees of different species and genera. Investigations of this character are important because only by such studies can the factors be determined which stimulate cambium activity. It is essential also to determine the period and extent of phloem and xylem formation in trees and the duration of cambium activity. Much more work remains to be done along this line. Such work is of especial importance in fruit culture and in a subsequent paper the results of such an investigation will be presented.

Cornell University.

\section{Explanation of figures}

FIG. I. Cutting no. 6 made from trunk on November I3 $_{3}$ showing cambium tissue $a$ to $a$, consisting of six rows of cells; $\times 475$.

FIG. 2. Shows extent of cambium in basal cutting, No. to, made on May" 5 . Compare with Fig. $2 ; \times 475$.

FIG. 3. Cutting no. 6 taken from trunk of tree $A$ on May 5. Cambium $a$ to $a$. Note the increased diameter and cell differentiation; $X_{475}$.

FIG. 4. Cutting no. 5 made on May 25 from tree $A$. Xylem formation not yet begun; $\times 33$.

FIG. 5. Cutting no. 4 from tree $C$ made on June $3 ; \times 33$.

FIG. 6. Cutting no. 7 from tree $C$ made on June $30 ; \times 33$.

FIG. 7. Cutting no. 8 from tree $C$ made on July 8. Differentiation of summer wood is beginning; $\times 33$.

\footnotetext{
*Whitten, J. C., loc. cit.
} 


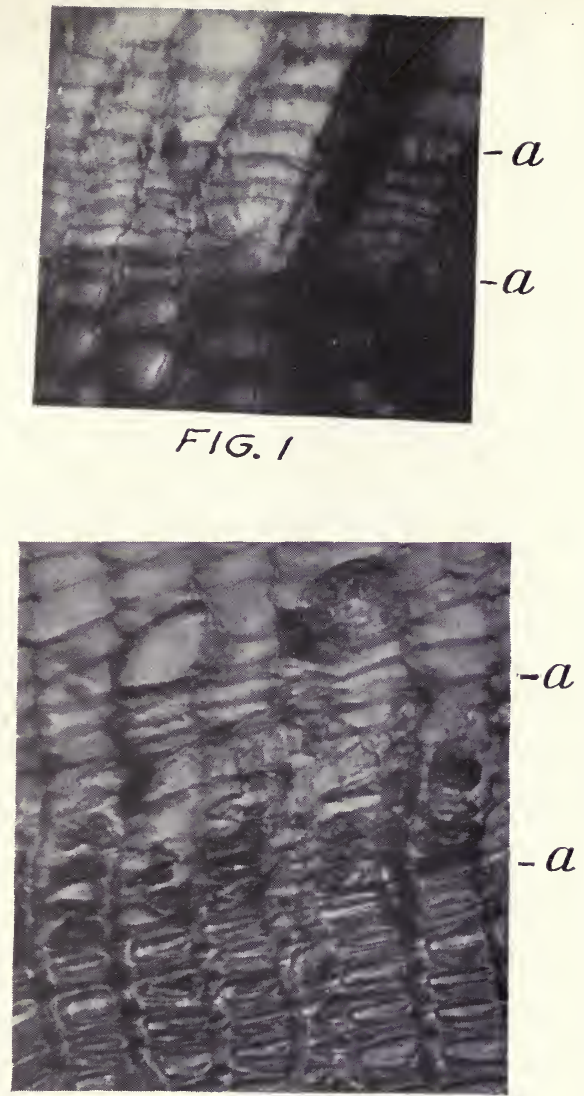

FIG. 2

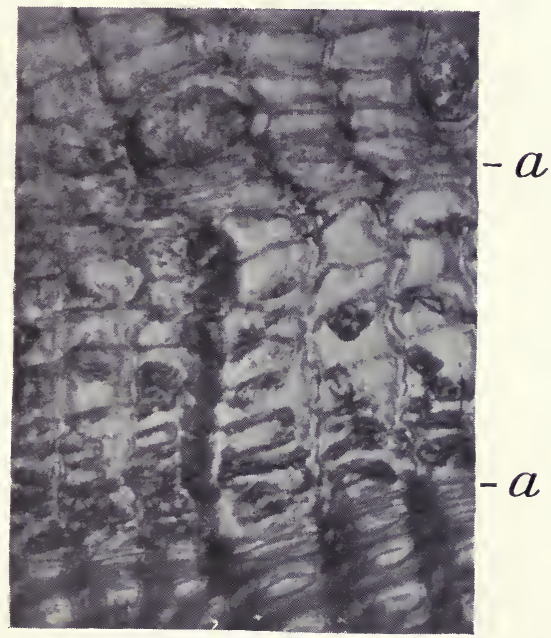

$$
\text { FIG. } 3
$$





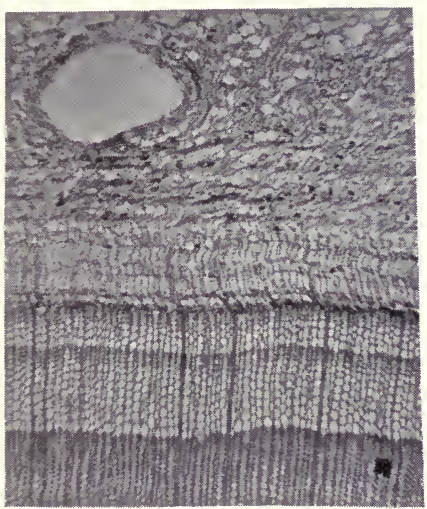

FIG. 4

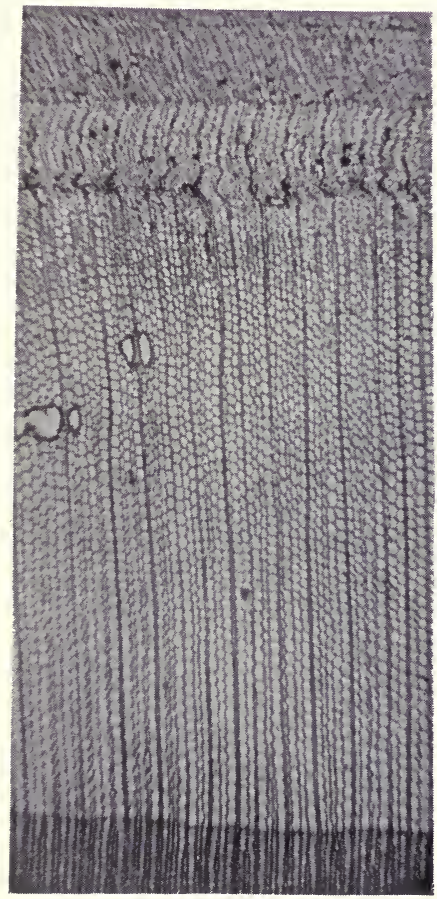

FIG.T

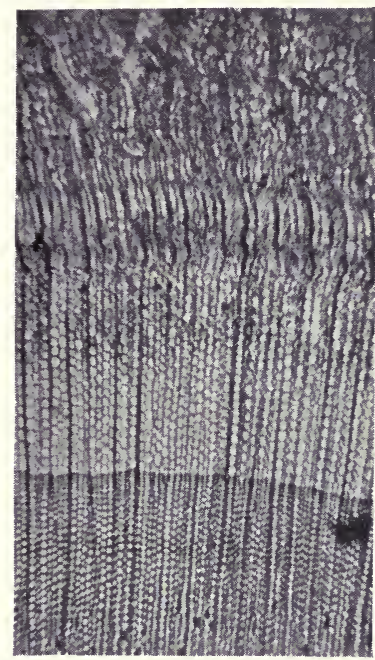

FIG. 5

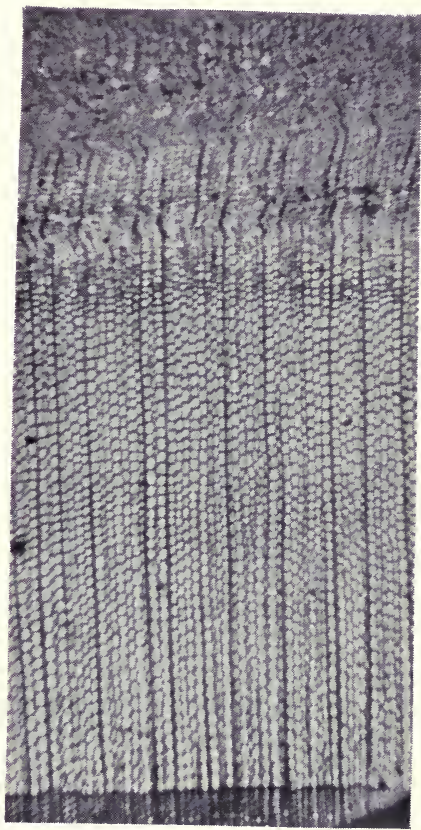

FIG. G

KNUDSON: CAMBIUM IN THE AMERICAN LARCH 





all of Nuttall's species, a gratifying result which the writer did not anticipate when the work of comparison was under way. This necessitates the restriction of S. fluviatilis Nutt. to its original use as a name for the forms with long-pedicelled pistils. It is apparent that recent authors have interchanged the names $S$. argophylla and S. sessilifolia, thereby adding to the confusion of the Californian species. S. brachycarpa Nutt., usually referred as a synonym to some species of this group, does not belong here at all but is S. stricta (Anders.) Rydberg, S. desertorum Rich. of recent authors. Since Nuttall's is the oldest name it should stand.

\section{Synopsis of Species}

Leaves very small, $\mathbf{I ~ c m}$. long, awl-shaped; aments oval, $1 \mathrm{~cm}$. long, gland in staminate flower one.

r. S. microphylla.

Leaves larger, $2 \mathrm{~cm}$. or more in length ; aments more or less elongated, glands in staminate flower two or more (except in $S$. Thurberi).

Capsules hairy, at least when young.

Aments densely flowered, species of the Pacific slope.

Stigma raised on a distinct style.

Leaves linear-lanceolate, coriaceous; aments on long leafy peduncles. Aments small, $\mathbf{r}-2 \mathrm{~cm}$. in length and few-flowered, usually in threes at the ends of the branches. 2. S. taxifolia.

Aments medium size, $3 \mathrm{~cm}$. or more in length, cylindrical, manyflowered, usually solitary at the ends of the branches.

3. S. Parishiana.

Leaves elliptical or elliptical-lanceolate, membranous ; aments larger on shorter peduncle.

Leaves densely silky hairy throughout ; aments medium size, 2-5 $\mathrm{cm}$. long.

4. S. macrostachya.

Leaves not densely silky ; aments large, $6-8 \mathrm{~cm}$. long.

5. S. sessilifolia.

Stigmas sessile; leaves entire or nearly so, stipules wanting.

6. S. argophylla.

Aments loosely flowered, species east of the Rocky Mountains.

Capsules silvery white with appressed sillky hairs.

Capsules thinly pubescent.

7. S. Thurberi.

8. S. interior.

Capsules strictly glabrous.

Leaves entire or spinulose-denticulate, coriaceous.

Capsules pedicelled; leaves denticulate.

Capsules sessile; leaves entire.

9. S. fuviatilis.

10. S. exigua.

Leaves closely and prominently serrate, not coriaceous.

Leaves distinctly glaucous and prominently veiny beneath.

II. S. melanopsis.

Leaves not distinctly glaucous nor veiny beneath.

12. S. Bolanderiana. 
I. Salix microphylla Cham. and Schlecht. Linnaea, 6: 354 . I 83 I

Heretofore this species has been considered identical with $S$. taxifolia H.B.K. A comparison of the original descriptions, both of which were very carefully drawn, indicates that the two are distinct. The plate and description by Hooker and Arnott in Bot. of Beechy, Voy. 3I. pl. 7o, confirms the conclusion that this species is distinct. I have seen but one specimen: Palmer's no. I I93, "a shrub $4 \mathrm{ft}$. high growing on the bank of a river" at Colima, Mexico. It is well said in Hooker and Arnott's description that this is "a very remarkable species of Salix with leaves like those of some small Lythrum." So far the pistillate plant has not been seen.

2. Salix taxifolia H.B.K. Nov. Gen. et Sp. $2: 22$

This species is well described and illustrated in Sargent's North American Sylva. It has been collected by Pringle and Tuomey in Arizona, also by Pringle in Chihuahua, Mexico. It is a large shrub or small tree.

\section{Salix Parishiana sp. nov.}

A slender shrub, one to three meters high, bark grayish or brown, young twigs cinereous strigose: leaves linear-lanceolate, minutely and remotely denticulate, $5-7 \mathrm{~cm}$. long by $3 \mathrm{~mm}$. wide, silky canescent when young, glabrous and somewhat coriaceous when mature, veins few but very prominent: stipules none: aments on long leafy peduncles, appearing about April I, 2-3 $\mathrm{cm}$. long by $\mathrm{I}-2 \mathrm{~cm}$. peduncles often $\mathrm{IO} \mathrm{cm}$. long, the upper leaves of the branch much surpassing the ament: ament densely flowered, scales white densely villous all over, oblong, acute : filaments scantly hairy at the base : capsules densely villous, oblong, closely sessile : style distinct : stigmas linear, three times as long as thick.

A very peculiar form, differing from $S$. taxifolia by its larger leaves and cylindrical aments and quite distinct from other species with linear stigmas.

California: Matilija Cañon, San BernardinoCo. (F. W. Hobby, nos. 54, 55), Springs Valley, Inyo Co. (F. V. Coville and F. Funston, no. 263).

Mr. S. B. Parish writes "that it is not uncommon near San Bernardino." 


\section{Salix macrostachya Nutt.}

S. sessilifolia villosa Anderss. DC. Prodr. 16²: 215.

Shrub or small tree $\mathrm{I}-6$ meters high, often in dense thickets, bark light brown, cinereous, young branches villous : leaves $5 \mathrm{~cm}$. long, I cm. wide, sessile, entire or nearly so, oblanceolate or narrowly elliptical, acute at both ends, more or less villous pubescent, sometimes (as in Brewer's no. 544) lanate all over: stipules obsolete: aments on short, leafy, lateral branches, $2-3 \mathrm{~cm}$. long, densely flowered, oblong, scales densely villous all over, oblong, filaments crisp, villous upon the lower half: capsules clothed with long lax hairs, closely sessile : style evident: stigmas divided, linear.

\section{Salix macrostachya leucodendroides var. nov.}

One to three meters high, wood soft : leaves much larger, IoI $2 \mathrm{~cm}$. long, I cm. wide, densely white tomentose on both sides, largest remotely denticulate: aments larger, cylindrical, 4-5 cm. long, otherwise as in the type.

Extremely broad leaved forms occur with texture and vesture of $S$. Bebbiana, leaves $4-6 \mathrm{~cm}$. long, $\mathrm{i}-1.2 \mathrm{~cm}$. wide, ovate on short but distinct petioles, twigs, leaves and capsules densely villous with whitish spreading hairs.

This species has not been reported beyond the limits of California and Oregon. San Bernardino (W. G. Wright, nos. 6, 7, IO and I I), Santa Rosa to Ukiah (W. H. Brewer, no. 3854), Lake Co. (E. L. Greene, no. 229), Putah Creek, Solano Co. (W. L. Jepson), Narsismente River (W. H. Brewer, no. 544), Martin Co. (W. H. Brewer, no. 2360), Clear Lake (H. N. Bolander, no. 3854). Specimens in herbaria representing this species are frequently labelled S. Hindsiana. From Bentham's description of $S$. Hindsiana, which is ample and concise, there is little doubt that his specimen was S. argophylla.

S. integrifolia var. leucodendroides is a very. striking form from southern California collected by Mr. S. B. Parish, nos. 2 I 34, 2040 and 640. There does not seem to be enough difference to warrant its separation as a species although intergrading forms are wanting. It grows in wet soil.

5. Salix sessilifolia Nuttall, Sylva, i : 68 . $184^{2}$ Salix sessilifolia Bebb, et al. (in part).

Shrubby or often treelike, 2-IO meters high, older branches 
glabrous and brown : shoots very leafy, hoary puberulent: leaves membranous in texture, elliptical, acute at both ends, $5-10 \mathrm{~cm}$. long, I-2 cm. wide, closely sessile, obscurely and rather remotely denticulate, hoary with rather long pubescence when young, glabrous at maturity, veins prominent : aments large, upon lateral shoots 6-8 cm. long, .75-1 cm. thick, often three borne on a single branch, very densely flowered, six to ten leaves on the peduncle, flowering in July or late in June, scales oblong or obovate, rounded or retuse at the apex, nearly or quite glabrous, narrower in the pistillate ament, lower half of filaments very hairy, upper half minutely puberulent, capsule lanceolate, clothed with silky hairs when young becoming nearly glabrous at maturity, closely sessile : style evident : stigmas linear, several times longer than thick.

Shorter and relatively broader leaves, glabrous scales, pubescent capsule, evident style and linear stigmas are the distinguishing features of this species. The name was first applied to plants collected in the Columbia River valley.

Oregon: Sand Bars, Columbia River (T. J. Howell), Multnomah Co. (T. J. Howell).

6. Salix argophylla Nuttall, Sylva, I : 7i.pl. 20 . 1842

Salix longifolia, var. argophylla Anderss. DC. Prod. I6 $6^{2}$ I 4. I 868 .

Salix fluviatilis var. argophylla Sargent, Sylva, 9: I $24 . \quad$ I 896.

Salix Hindsiana Bentham, P1. Hartw. 335. 1857.

Tree or large shrub usually 5 meters high forming dense thickets but not growing in clumps, at any rate each bush distinct so far as the parts above ground are concerned, young twigs puberulent, branches nearly glabrous and exceedingly tough, bark turning from brown to bright yellow or orange just before blooming making a thicket of it a most conspicuous object: leaves narrowly lanceolate, $5 \mathrm{~cm}$. long, $\mathrm{I}-2 \mathrm{~cm}$. wide, closely sessile, entirely or rarely minutely and remotely denticulate, clothed equally on both sides with an appressed silky pubescence which more or less conceals the veins, stipules obsolete (rarely on very vigorous shoots minute ones occur. Occasionally the leaves remain upon the plant over winter, the young shoots appearing in their axils in spring: ament surpassed in length by its leafy peduncles, $3-5 \mathrm{~cm}$. long, I-2 cm. thick, six to eight leaves on the peduncle somewhat smaller than the leaves on the shoot otherwise like them, aments often in pairs or threes at the ends of the branches, appearing in May in Oregon and northern California and flowering intermittently all summer, scales oblong and obtuse in the staminate 
ament, narrower and more acute in the pistillate, glabrous on the back, crisp, hairy on the margin and toward the base, erose toward and at the apex, lower half of the filament densely crispy hairy: capsule lanceolate, covered with straight appressed silky hairs, closely sessile : stigmas sessile, oblong, about twice as long as thick, mature capsule often nearly glabrous.

This species is distinguished by its narrowly lanceolate entire leaves, obsolete stipules, small and rather narrow aments, erose scales and hairy capsules.

Salix argophylla occurs on the Pacific slope from southern California to British Columbia.

California: Panamint Mountains (F. V. Coville and F. Funston, no. 788), Sierra Valley (J. G. Lemmon), North Idria (H. N. Bolander, no. 766), Yosemite Valley (Anderson), San Bernardino (W. G. Wright, nos. 3 and 4), Banks of the Merced (W. H. Brewer, no. 503I), Tulare Co. (F. V. Coville and F. Funston, no. I 267), San Bernardino (S. B. and W. F. Parish, nos. 640, 2 I 40).

Oregon: Union Co. (W. C. Cusick, no. I 044), Hood River (J. and T. H. Howell).

Washington: Klickitat Co. (W. N. Suksdorf, no. 34), Sprague (Leiberg and Sandberg, no. I 34); British Columbia: Spences Bridge, Thompson River (J. M. Macoun, no. I3).

\section{Salix Thurberi sp. nov.}

Slender shrub two or three meters high; bark of older branches brown and glabrous, younger branches puberulent : leaves linearlanceolate, $6-8 \mathrm{~cm}$. long, $2-3 \mathrm{~mm}$. wide, sessile, evenly denticulate, thin, midrib prominent, silvery silky when young, becoming glabrate: stipules none: aments on long leafy peduncles 5-6 $\mathrm{cm}$. in length : flowers borne in verticels, axis silvery canescent, scale lanceolate, acute, midvein prominent : capsule densely clothed with silvery white ascending hairs, very short pedicelled, gland about equaling the pedicel : style very short: stigmas divided: red, stamens with filaments hairy below, gland in staminate flower one.

This species occurs in southern and western Texas and was observed and collected there by Geo. Thurber many years ago. His specimens (nos. 2368, 95, and 234I) are in the Gray Herbarium. It has been referred heretofore to $S$. interior; it is easily distinguishable from that species by the long thin leaves, single 
gland in the staminate flower, silvery silky capsules, and red stigmas.

8. Salix interior nom. nov.

Salix rubra Rich. Franklin Journ. App. $7: 765$. I823. Not Huds. 1762 .

Salix longifolia Muhl. Neue Schrif. Gesell. Nat. Berl. 4: 238. pl. 6.f. 6. I So3. Not Lam. I 778.

Salix fluviatilis of Sargent and other recent authors in part.

Varying in stature from a low shrub to a small tree, usually growing along streams and lake shores: twigs smooth and brown to densely tomentose and gray : buds plano-convex with an obtuse and rounded apex, very small: leaves nearly or quite smooth, sparsely canescent, to extremely canescent, sessile, linear-elliptical, ordinarily $8-10 \mathrm{~cm}$. long and less than $\mathrm{I} \mathrm{cm}$. wide, varying to much wider in young vigorous shoots, remotely dentate, the teeth narrow, sometimes quite spinulose: stipules conspicuous, ear-shaped, obscurely denticulate, deciduous : aments of late spring on short lateral peduncles, which bear four to six leaves, those borne later in the season on much longer leafy branches, very loosely flowered, the flowers fascicled in clusters of two to five on the axis, a distinct interval between the fascicles, first appearing in May and often bearing a second set of aments in early summer; at anthesis, aments $2-4 \mathrm{~cm}$. long and $\mathrm{I}-2 \mathrm{~cm}$. thick; scales usually glabrous or somewhat hairy toward the base, narrowly oblong, yellowish, deciduous, after flowering: glands large, two in the staminate, one in the pistillate flower : filaments crisp hairy below, smooth above : capsules sessile, clothed when young with appressed silvery hairs, becoming nearly smooth at maturity : stigmas short, sessile: style none.

The pistillate ament, lax at anthesis, becomes more so as the capsules mature and by this character the species can easily be distinguished from related species.

\section{Salix interior Wheeleri var. nov.}

Low shrub : young twigs whitened with appressed silky hairs, becoming glabrous toward the end of the first season's growth : leaves relatively short and broad, $7-8 \mathrm{~cm}$. long by $1 \mathrm{~cm}$. broad, minutely and evenly denticulate, closely sessile, densely silky on both sides, veins nevertheless evident, rather abruptly acute.

Throughout the Upper Mississippi valley and the basin of the Great Lakes. Also occasionally upon the eastern slopes of the 
Allegheny Mts. Specimens representing the species have been seen as follows :

Missouri : St. Louis (H. von Schrenk).

Ir.LInors: Rockford and Fountaindale (M. S. Bebb).

Minnesota : Redstone (H. Mann).

Michigan : Flint (D. Clarke).

Oнı : Painesville (H. C. Beardslee, nos. 48 and 73).

New York : Buffalo (G. W. Clinton); Cayuga Lake (W. R. Dudley).

Pennsylvania : Easton (A. P. Garber), McCalls Ferry (T. C. Porter).

The variety Wheeleri is confined to the basin of the Great Lakes. Specimens have been seen from:

Illinois : Fountaindale (M. S. Bebb, nos. i i 8 and I I9).

Michigan : Flint (D. Clarke), Black Lake, Choboygan Co. (C. F. Wheeler, no. 3).

Оніо: Painesville (H. C. Beardslee, no. 67).

Ontario : Point Abino (W. W. Rowlee).

Pennsylvania : Presque Isle, Lake Erie (T. C. Porter).

New Brunswick : Frederickton (J. Britten, nos. 4 and 6). The silvery vesture of this shrub is much like that of S. argophylla of the Pacific Coast.

Narrow-leaved individuals occur in the extreme western and southwestern range of the species, and seem to connect this species with the preceding:

Missouri : Courtney (B. F. Bush, no. 9).

Nebraska : Emerson (Clements, no. 2509). The vesture of the capsule, and the glands in the staminate flower afford a decisive distinction between them.

9. Salix fluviatilis Nutt. North Am. Sylva, I : 73. 1842

Salix longifolia pedicellata Anderss. Sven. Vet. Akad. Handl. IV. $6: f \cdot 35$. I 867 .

Distinguished from the next species to which it is closely related by its pedicelled capsules and by its remotely denticulate leaves. It has the same general range as $S$. exigua but seems to be much less frequent. 
Colorado (Hall and Harbour, no. I32) (Brandegee).

New Mexico : Pecos River, San Miguel Co. (A. A. \& E. G. Heller, no. 3684); North American Pacific Coast Flora, etc. (C. C. Parry, no. 306).

io. Salix exigua Nuttall N. Am. Sylva, I : 75. 1842

Salix Nevadensis Watson, Am. Nat. 7: 302. 1873.

Variable in stature from a low slender shrub to a small tree: branches light brown, leaves $4 \mathrm{~cm}$. by $\mathrm{I}-2 \mathrm{~cm}$., yellowish, closely sessile, opaque, entirely or nearly so, canescent when young, usually becoming quite glabrous at maturity, very narrowly elliptical, veins very indistinct, stipules none: aments $2-5 \mathrm{~cm}$. long on peduncles about the same length, appearing with the leaves, rather densely and evenly flowered, sometimes the lower flowers remote, scales in the staminate ament oblong to obovate, in the pistillate narrower and longer, smooth or more or less crisp villous on the margins : capsule closely sessile, lanceolate, glabrous, light green : stigmas short and thick, sessile, sometimes even appearing slightly sunken in the apex of the capsule.

Readily distinguished from related species by its entire opaque leaves and glabrous capsules.

\section{Salix exigua virens var. nov.}

Leaves large, IO-I $2 \mathrm{~cm}$. long, I cm. wide, nearly glabrous, veins conspicuous on both sides, distinctly denticulate: stipules large, oblong denticulate: aments large, the pistillate $4 \mathrm{~cm}$. long, $\mathrm{I} \mathrm{cm}$. thick, sometimes borne in threes at the ends of the long leafy shoots.

Easily distinguished from the type by the size and texture of the leaves and the presence of stipules.

Salix exigua occurs throughout the Rocky Mountain region of the United States, but has not yet been reported from British America or Mexico. It seems probable, however, that it will be found both north and south of the range indicated. Prof. Aven Nelson observes that in Wyoming this species grows on positively the "worst alkali soil that can be imagined, where it is small, slender, and twig-like, but of dense growth."

California : Surprise Cañon and Hot Springs, Inyo Co. (F. V. Coville and F. Funston, nos. 722 and 68I), San Bernardino (W. G. Wright, no. 2), Cashewberry Springs, Mohave Desert (S. B. 
Parish), Aqua Caliente, Colorado Desert (S. B. and W. F. Parish, no. 729).

Arizona: San Francisco Mountains (H. H. Rusby, no. 37 I), Tuçson (G. Vasey, no. 7) ; Nevada (S. Watson), Virginia City (Bloomer).

UTAн : Dirty Devil River (L. F. Ward, no. 399).

New Mexico: Crow Agency (T. C. Porter, no. 5).

Colorado: Platte River (T. C. Porter, no. 6), Ft. Collins (C. F. Baker, nos. 4 and 5), Headwaters of Clear Creek (H. N. Patterson).

Wyoming : Bitter Creek, Platte Cañon, Pine Bluffs, Ft. Steele, Laramie (A. Nelson, nos. 245, 2740, 2885, 3 I O2, 3 I 37), Yellowstone Park (J. N. Rose, no. 90), Ft. Bridger (T. C. Porter).

South Dakota: Hermosa, Black Hills (P. A. Rydberg, no. IO2O).

Montana: Jefferson River (F. L. Scribner), Jacks River (W. M. Canby, no. 3) (Tweedy).

IDAHo: Lewiston (A. A. Heller, no. 3007).

Washington: Pullman (C. V. Piper, no. I 774).

Oregon: Umatilla River (J. and T. H. Howell).

The variety virens is quite distinct and may upon further investigation prove to be of specific rank. It is apparently confined to Arizona and southern California.

Arizona (J. T. Rothrock).

California: San Bernardino (W. G. Wright, no. 2), Dos Cabesas (C. R. Orcutt, no. 2227); Kernerville (W. G. Wright ; Santa Isabel Creek, San Diego Co. (R. D. Anderson, no. 700), A. Kellogg and W. G. Harford, no. 922), banks of the Merced, near Clarks (H. N. Bolander, no. $503 \mathrm{I}$ ).

\section{Salix melanopsis Nuttall, Sylva, I : 1842}

"Shrub or small tree, bark of old branches dark chestnut brown to nearly black, young branches puberulent, very leafy: leaves oblanceolate or elliptical, closely sessile, $5 \mathrm{~cm}$. long, I cm. wide, on vigorous shoots, glabrous when mature, silky hairy when young, very distinctly veiny beneath, somewhat glaucous, the margin with rather low and close serrations : stipules lanceolate, few toothed: aments long and slender, often flexuous on peduncles which bear 5-8 leaves, 5-7 cm. long, I-2 cm. thick, cylindrical, loosely 
flowered at the base, scales linear-oblong, more or less erose at the apex, filaments hairy to the middle, or rarely nearly glabrous : capsule lanceolate, glabrous, short-pedicelled, pedicel however not longer than the gland: style very short and stigmas short and thick : ovary smooth with four sessile stigmas." (Nuttall.)

Typical specimens show a strong resemblance to Salix nigra.

Salix melanopsis is confined to the western slope of the Rocky Mountains and occurs from British Columbia to Oregon. It is particularly abundant along the Columbia River where Nuttall saw it. Its leaves are very large especially upon young shoots. Specimens collected in Cowlitz Co., Washington, by Mr. Coville, have remarkably large leaves and pistillate aments. Specimens seen are as follows :

Oregon : Cow Valley, Eagle Creek Mountains (W. C. Cusick, Nos. I 800a, I303), Blue Mountains (L. F. Henderson) (E. Hall).

Washington: Pehistin (Sandberg and Leiberg, no. 480), Klickitat Co. (W. N. Suksdorf, nos. 35, 36, 37, 38) ; Snoqueline Falls, King Co. (C. V. Piper and E. C. Smith, no. 6r4).

British Columbia: Revelstoke, Long Arrow Lake, Upper Liaird River, wet places, Valley of Fraser River, Columbia River Valley (J. Macoun, nos. 6, 23, 26, 28, 28a).

\section{2. Salix Bolanderiana sp. nov.}

Bark of older branches nearly black: aments $4 \mathrm{~cm}$. in length, the pistillate fully I $\mathrm{cm}$. thick, borne on long leafy branches: leaves $8 \mathrm{~cm}$. long, I cm. wide, closely and very finely serrate, scale spatulate, filaments crisp villous throughout : capsule ovate, closely sessile: stigmas minute, sessile.

In the Yosemite Valley in California (Bolander, nos. 49, 58, 4958, 503 I).

\section{Explanation of Plate 8}
1. Salix microphylla.
8. S. sessilifolia.
2. S. taxifolia.
9. S. Bolanderiana.
3. S. Parishiana.
II. S. exigua virens.
4. S. macrostachya.
5. S. macrostachya Cusickii.
12, 13. S. interior.
6. S. macrostachya leucodendroides.
14. S. interior Wheeleri.
7. S. argophylla.
15. S. exigua.
16. S. melanopsis. 

Bull. Torr. Bot. Club, 28.

PL. 9.

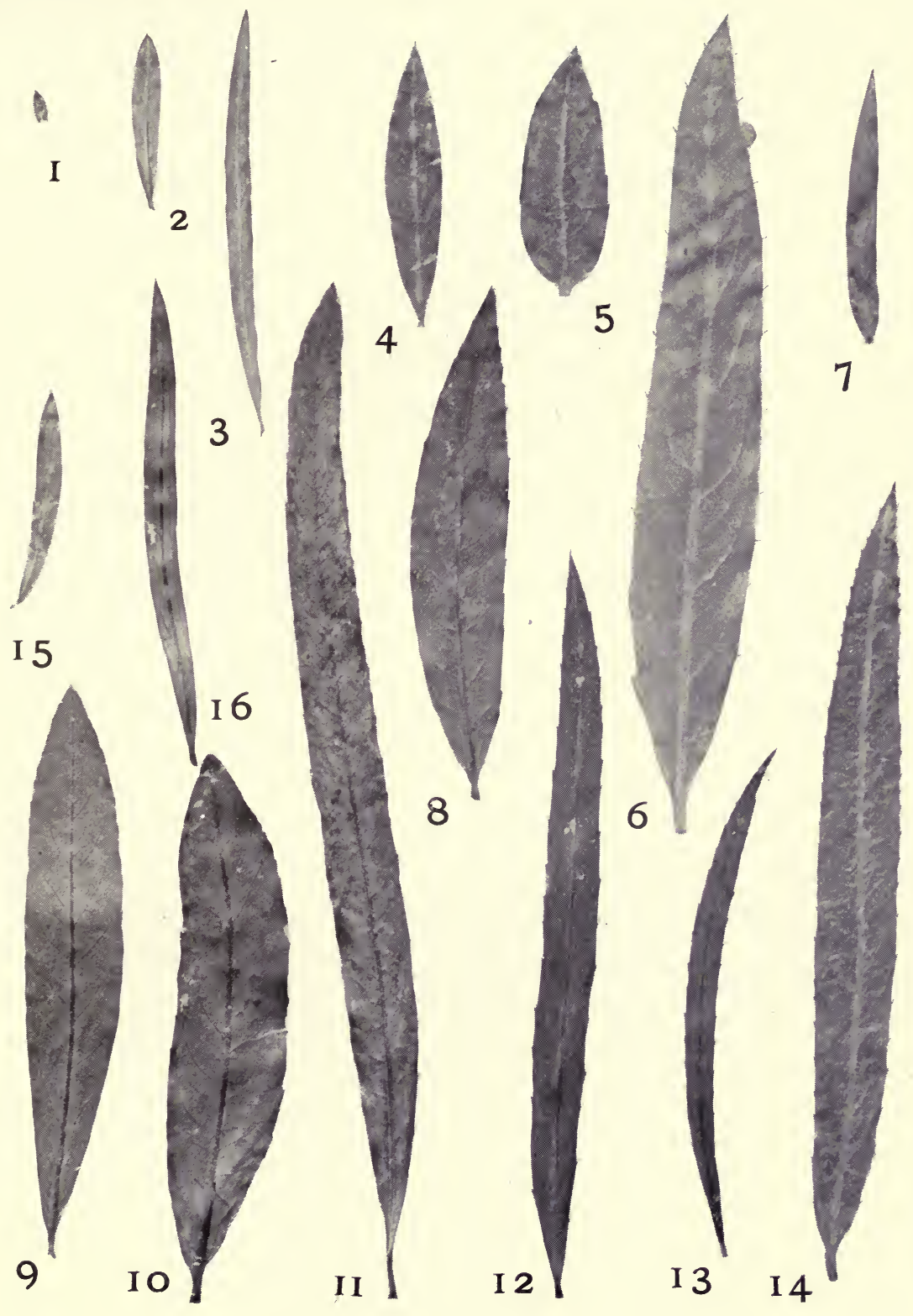



[Reprinted from TORREYA, Vol. 13, No. 6, June, 1913.]

\section{A CASE OF ABNORMAL DEVELOPMENT OF A SHORT GROWTH IN PINUS EXCELSA}

By Arthur H. Graves

The characteristic development in the genus Pinus of two sorts of shoot axes - long and short-is well known to all who are acquainted with the genus. The long growth (Langtrieb) is represented by the main axis or axes of the shoot system; the short growths (Kurztriebe) consist of much abbreviated branches which are borne on the long growth, arranged spirally upon it, and subtended by its scale-like leaves. These short growths or branches are characterized primarily by the fascicles of leaves they bear; each one, in the group of the white pines, developing normally five leaves, in a whorl-like cluster or "fascicle." Microscopical examination shows near the base of these leaves, and surrounded by them, a tiny growing point at the terminus of the short growth. Under ordinary conditions this growing point never develops further; and at the end of two or two and one half years the whole short growth is shed, in essentially the same manner as a leaf is cast from one of our deciduous trees.

Under special conditions, however, as for example when the growing point of the long growth is injured, a development of a short growth into a long growth rarely occurs.* An interesting case of this kind was recently found by the writer on a tree about I5 years old of Pinus excelsa Wall. in the New York Botanical Garden, and is illustrated in figure I. The five leaves composing the original fascicle may be seen at the base of the shoot, one of them having been slightly twisted in order to show

* Engler, A., und K. Prantl. Die natürlichen Pflanzenfamilien nebst ihren Gattungen und wichtigeren Arten insbesondere den Nutzpflanzen. 21: 29 note. Leipzig. I889. 


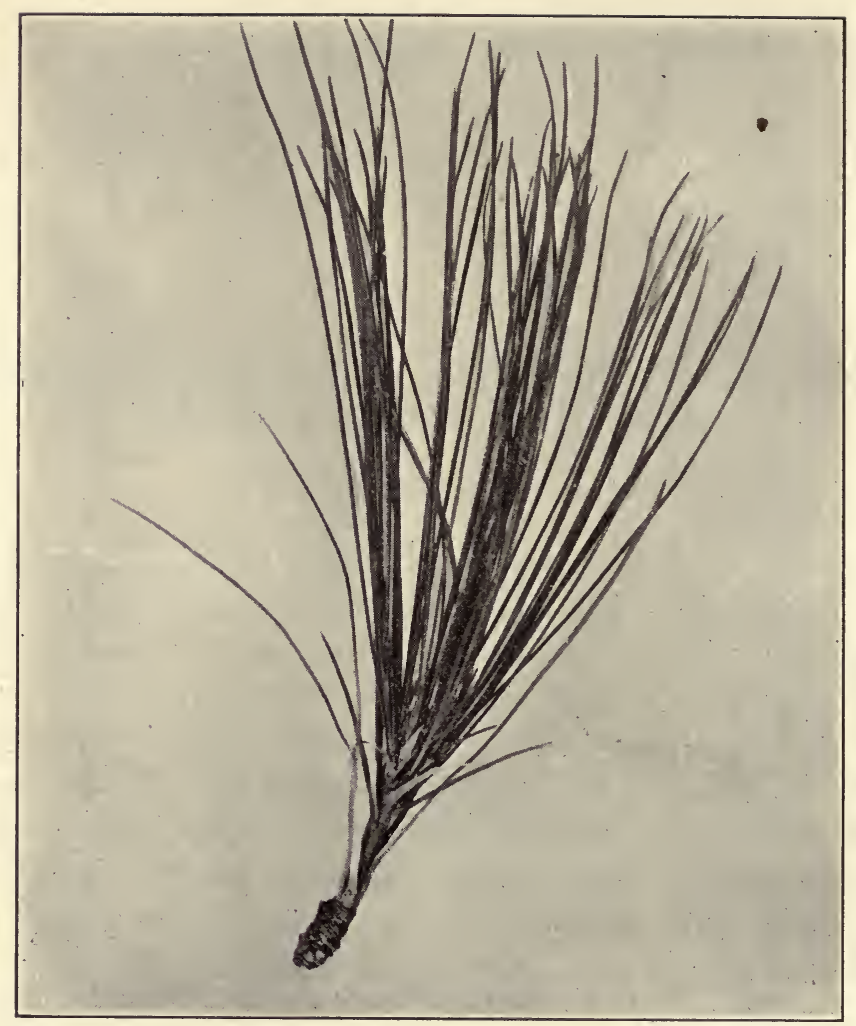

FIG. I. Photograph, showing abnormal development of short growth into long growth in Pinus excelsa Wall. About $3 / 4$ nat. size.

the latter to better advantage. It is quite evident that the shoot has developed from the growing point of the short growth, which, as above stated, normally atrophies and dies. The cause of this abnormal development is probably to be looked for in the dying out, due to injury of some sort, of the growing point of the long growth. All that remains of this may be seen in the figure as a small prominence to the left of the base of the original leaf fascicle.

It was asserted above that this phenomenon is a rare occurrence, a statement which should perhaps be qualified by adding that it is rare in trees older than the seedling stage. For the writer has seen not only buds develop at the terminus of the short 
growth in especially vigorous two or three year old white pine (Pinus Strobus L.) seedlings, in the nursery of the Yale Forest School; but also fully formed shoots, which, judging from the five leaves at their base, have clearly developed from such short growth buds.

Professor J. W. Toumey, of the Yale Forest School, states that he has seen, in the vicinity of New Haven, a large tree of Pinus Strobus L., which, as a result of some kind of injury, had developed a considerable number of its short growths into long growths.

Pinus excelsa Wall., from which the shoot illustrated was taken, is also a member of the white pine group. It is commonly known as the Bhotan pine, and is a native of the Himalayas. As far as the writer can ascertain, the abnormality under discussion has not been before recorded for this species. According to Penzig, * however, the phenomenon has been noted in Pinus sylvestris $\mathrm{L}$. by several observers.

YaLE UNIVERSITY,

New Haven, Conn.

* Penzig, O. Pflanzen-Teratologie 2: 497. Genoa. I894. 



\section{Walter Mulfoend}

THE TAXONOMIC VALUE OF THE STAMINATE FLOWERS OF SOME OF THE OAKS.

(WITH EIGHT FIGURES)

THE flowers of the oaks have received comparatively little attention from investigators in systematic botany. Most authors have described the flowers of a single species, usually Quercus alba, which they have considered as a type for the entire genus. Sargent in his Silva has given a brief description of the flowers of each species, but the degree of variation in the form of the lobes and the amount of pubescence is hardly touched upon.

The present study was undertaken in order to determine whether there was not a wider range of forms among the flowers, and, if so, whether this variation is constant enough to aid in the separation and limitation of the species. For this purpose the staminate flowers of the oaks in the Cayuga Flora (Q. acuminata, Q.alba, Q. platanoides, Q. Prinus, $Q$. macrocarpa, $Q$. rubra, $Q$. coccinea, and $Q$. velutina) were chosen.

Staminate flowers were collected from as many trees of each species as possible at anthesis. The flowers were opened, the stamens removed, and the perianth mounted in glycerine jelly. In order to determine the limits of the midrib it was found of assistance to warm the slide after mounting.

The oaks may be divided into two groups, one containing those which require a single season for maturing their fruit, the other requiring two seasons. Of the oaks enumerated above the first five belong to the first group, the last three to the second. This same division is substantiated by a study of the floral organs.

The first group has a six-lobed perianth that is campanulate to rotate, and has six to nine stamens. The second group is easily distinguished from the first by its closely companulate perianth, and the stamens are four or five in number. The different species in each group may be distinguished by the size and shape of the lobes, the amount of pubescence, and the presence or absence of a midrib.

Quercus acuminata.- - This species has a six-lobed, thin, and delicate rotate perianth, which is $3^{\mathrm{mm}}$ in diameter. The lobes are usually 
somewhat unsymmetrical, two or three being close together and separated by narrow sinuses, the others are more widely separated and the sinuses are correspondingly wider and deeper. This appearance is often due to tearing in mounting, but the natural lobing may be determined by tracing the cilia along the margin. The lobes are ovate to

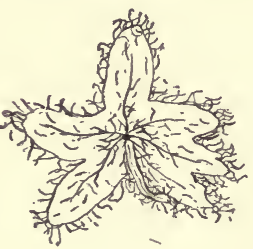

FIG. I.-Q. acuminata. lanceolate and obtuse. One of the lobes is frequently somewhat broader than the others, and once or twice notched near the apex. The midrib is distinct and extends a little over one third of the length of each lobe. The perianth is pilose, and the hairs are usually

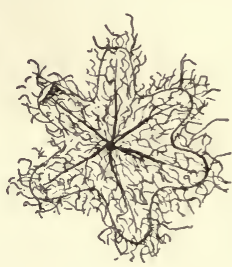

FIG. 2.-Q. alba. tinted with red. The bract is persistent, and adheres closely to the flower when the latter is removed from the catkin. This is the only species of this region that does not lose the bract before the maturing of the flower.

Quercus AlBa.-The flowers of $Q$. alba are very symmetrical in outline, thus forming a strong contrast to the preceding species. The perianth is slightly campanulate, thin, delicate, and five or six-lobed. The diameter is $2-3^{\mathrm{mm}}$. The lobes are small, broadly oval to ovate, and obtuse. The midrib is prominent and distinct nearly to the apex of the lobes. The perianth is densely pilose, the hairs being long and matted, rendering it difficult to spread the flower without tearing.

Quercus platanoides. - The flowers of $Q$. platanoides are only about one half the size of those of $Q$. alba, being $\mathrm{I}-2^{\mathrm{mm}}$, but resemble them closely in other respects. The

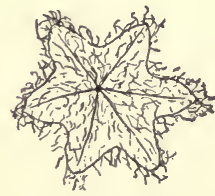

FIG. 3.-Q. platanoides. texture of the perianth is thicker. It is rotate rather than campanulate, and forms a flat six-lobed disk at the base of the stamens. The lobes are broadly oval to ovate, and separated by broad and obtuse sinuses.

The midrib is distinct nearly to the

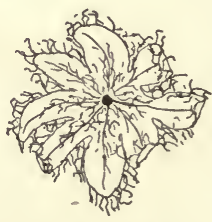

FIG. 4.-Q. Prinus. apex of each lobe. The perianth is pilose, but the hairs are not so thickly matted as in Quercus alba.

Quercus Prinus.-The perianth of Q. Prinus is small, thin, and deeply lobed. The diameter is from $2-2.5 \mathrm{~mm}$. It resembles the flowers of $Q$. alba, but the sinuses are much deeper and narrower, and the 
lobes are more spatulate or obovate. There is also a variation in the number of lobes; in the majority of flowers examined there were from six to eight, but occasionally one was found with as many as ten. The midrib is distinct at the base, but disappears near the apex of the lobes.

The perianth is sparingly

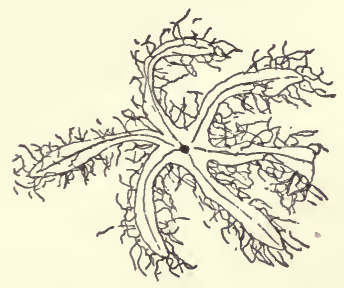

FIG. 5.-Q. macrocarpa. pilose, with the lobes ciliated by long slender hairs, giving it a very shaggy appearance.

QUerCUS MACROCARPA.Q.macrocarpa has a very characteristic flower. It is more deeply lobed than any of the preceding species, the sinuses extending nearly to the point of attachment. It is the largest of this group, having a diameter of $3-3 \cdot 5^{\mathrm{mm}}$. The lobes are long and very narrowly linear, five or six times as long as they are wide, and are frequently

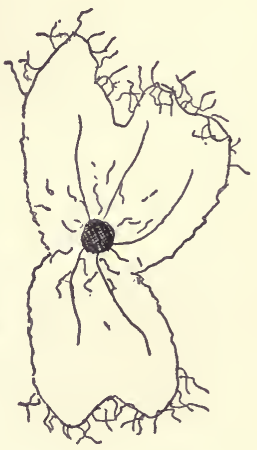

Fig. 6.-Q. rubra. slightly curled or twisted, making it difficult to separate them from the filaments of the stamens. The midrib is distinct to the apex of the lobes. The perianth is pilose, the hairs being very long and shaggy.

- Quercus RUBra.-The flowers of Q. rubra are much larger than any of the other forms studied, having a diameter of $4-4.5^{\mathrm{mm}}$. They are campanulate and indistinctly five or six-lobed. As the flowers

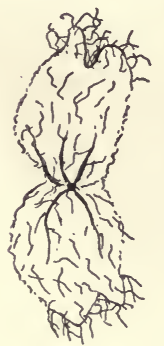

develop the stamens push through the narrow throat and tear the perianth into uneven segments varying in number from two to six. The midrib is distinct and slightly thickened at the base, but becomes indistinct about half way to the apex of the lobes. The perianth is nearly smooth or slightly pilose, and the lobes are thinly ciliate with long hairs.

Quercus coccinea.-Q. coccinea has a perianth that very closely resembles the one just described, although the other Fig. 7.-Q. characters of the tree are more frequently confused with $Q$. coccinea.

velutina than with $Q$. rubra. The perianth is campanulate and slightly six-lobed, with a diameter of $3 \cdot 5-4$ mm. Its four or five stamens as they develop tear it into two or three irregular segments. The midrib is distinct at the base but very soon disappears. The perianth is pilose, and there is a thicker row of cilia along the margin than was found in Q. rubra. 
Quercus velutina.-The last of this series, $Q$. velutina, has a very closely campanulate, thin and delicate perianth. The diameter is the

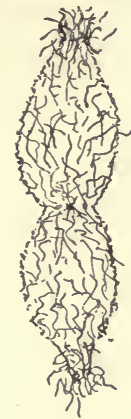
same as in $Q$. coccinea, $3.5-4^{\mathrm{mm}}$. The midrib is entirely wanting. The perianth is pilose, and the cilia along the margin are long and matted. The throat of the perianth is so narrow that it is torn by the stamens, as soon as they begin to develop, into two or three nearly equal segments. In the majority of cases the perianth had separated into two equal segments, but occasionally one was found with three, never with more.

The results of this study show that there is marked variation among the flowers, not only in the case of the Fig. 8. $-Q$. large groups, but also among the species in each, and the velutina. following key was based on these characters:

KEY TO NATIVE OAKS BASED ON THE STAMINATE FLOWERS.

A. Stamens six to nine.

I. Bract persistent after anthesis . . . . Q. acuminata

II. Bract deciduous before anthesis.

$a$. Perianth deeply lobed.

I. Lobes narrowly linear . . . . . Q. macrocarpa

2. Lobes obovate or spatulate . . . . . Q.prinus

$b$. Perianth with shallow lobes.

I. Perianth slightly campanulate: diameter $2-3^{\mathrm{mm}}$. Q. alba

2. Perianth rotate: diameter $\mathrm{I}-2^{\mathrm{mm}}$. . . Q. platanoides

B. Stamens four or five.

I. Midrib wanting . . . . . . . . Q.velutina

II. Midrib present.

a. Perianth pilose . . . . . . . Q. coccinea

b. Perianth smooth with lobes thinly ciliate . . Q. rubra

-W. W. Rowlee and Susie P. Nichols, Cornell University. 


\section{Palter Mulford \\ GROWTH STUDIES IN FOREST TREES \\ 1. PINUS RIGIDA MILL}

(WITH PLATES XXIV AND XXV)

HARRY P. BROWN

Reprinted for private circulation from

The Botanical Gazette, Vol. LIV, No. 5 , November Igr 2 


\section{GROWTH STUDIES IN FOREST TREES}

I. PINUS RIGIDA MILL

HA R R Y P. B R O W N

(WITH PLATES XXIV AND XXV)

The phenomenon of tree growth has long been a subject of investigation. Sachs, Hugo de Vries, Nördinger, Mer, the HARTIGS, WiELER, BÜsGen, voN MoHL, and a host of others have worked on problems concerned with it, and many papers presenting the results of investigations are to be found in the literature of the last half-century.

As might be expected, the question has resolved itself into a number of minor topics, each with its coterie of followers. Some have placed particular stress on spring and summer wood formation; others have studied growth as related to external factors or to inheritance. Various instruments have been devised to measure tree growth, and one author (REUSS 12) goes so far as to assert that thunderstorms cause a growth stimulus in trees. Investigations dealing with every phase of the subject are described in exhaustive detail, and yet with rare exception there is a maze of conflicting opinion sufficient to confuse even the careful reader.

The present studies were undertaken with a twofold purpose, namely, to clear up disputed points regarding annual ring formation in trees and to formulate laws of tree growth. Investigations were carried on upon various forest trees with this idea in view. The results of those on Pinus rigida are embodied in this paper.

Secondary thickening in trees arises as a general rule from a cambium which lives from year to year. This annually passes through certain active and certain dormant periods. The latter assertion, however, is to be taken in its broadest sense. In many tropical woods the interruption to growth can be detected only with a microscope, while in others it is totally lacking; the wood appears

s Contribution from the Department of Botany, Cornell University. No. I48. Botanical Gazette, vol. 54] 
as a homogeneous mass. The formation of this cambial layer takes place the first year, and is brought about by the linking together, so to speak, of the fascicular cambium of the primary bundles by the formation of interfascicular cambial zones, the result being a cylinder of merismatic tissue capable of division. There are, in addition to this, however, certain other growth phenomena. In the cortex of many trees, either near or remotely distant from the primary cambium, secondary cambial zones arise, whose function it is to form cork, the so-called cork cambiums. They are not united in a ring, as is the primary cambium, but extend for comparatively short distances in a peripheral direction. ${ }^{2}$ Again, as met with in the Cycadales and Gnetales (Coúter and Chamberlain 4), successive bundle-forming cambiums sometimes arise toward the periphery of the stem, and in such cases the life of the primary cambium is generally very short. Further, among dicotyledons there are a number of modifications of secondary thickening, particularly in underground parts. In the present studies, however, it is the intention to confine investigation to growth as it normally occurs in trees, that is, to the activities of a cambium which has certain active and certain dormant periods.

A number of specimens of Pinus rigida in the Cornell pinery as well as others in the wild state were used. Those in the nursery consisted of a number of individuals standing in a row which ran approximately east and west. The land sloped gently to the southwest and drainage conditions appeared to be good. The individual trees were about 22 years of age and seemed to be in a thriving condition. The height varied from 6 to $7 \mathrm{~m}$., depending on the vigor of the individual, and the average diameter at breast height was $12 \mathrm{~cm}$. In 1909, when investigation began, the branches extended to within I.2 m. of the ground. However, during the year above mentioned, the trees were pruned to a height of $1.9 \mathrm{~m}$. above the ground. Experiments were carried on with six individuals of this series, which were numbered I-VI.

The trees in the wild state had better be described separately, since each was of different age and external factors varied with the individual. For the sake of clearness they were designated as

2 Exceptions to this rule occur, resulting in the so-called "ring-barked" trees. 
$A, B$, and $C$. These specimens were growing in a strip of woodland about one mile north of the university campus. Conditions of soil and light appeared to be good in every case, that is, to all appearances the trees were not retarded.

Tree $A$ was a magnificent specimen about $25 \mathrm{~m}$. high; in other words, it had practically reached its maximum size. The trunk was slightly shaded to a height of $4.5 \mathrm{~m}$. by an undergrowth composed of white pine. There were no branches above for $18 \mathrm{~m}$. until the crown began. The latter was but fairly developed, being about what one might expect under forest conditions. At breast height, the caliper measure was $50 \mathrm{~cm}$. A conservative estimate of the age would be Ioo years.

Tree $B$ was a younger individual. Its height was approximately $20 \mathrm{~m}$., and crown development had progressed but poorly. At breast height the caliper measure was $26 \mathrm{~cm}$. The base was entirely free of undergrowth, and light conditions were better inasmuch as there were no close neighbors. Tree $B$ then differed from tree $A$ in (a) age, (b) light conditions, (c) crown development, (d) height, and (e) diameter.

Tree $C$ was about the age of those in the nursery, namely 20-25 years, and rose to a height of $7 \mathrm{~m}$. Branches were borne practically to the ground. The caliper measure was II cm. Illumination was better on the south side, due to the close proximity of a road, while on the north the underbrush encroached slightly.

\section{Methods}

Investigations began in the spring of I909, and the last cutting that year was made on July 6. Alternate cuttings were taken from two different individuals at intervals about a week apart, so that two weeks elapsed between incisions on any one tree. These were made in the following manner. Beginning from the base of the apical shoot, portions of the cortex and wood to a depth of at least one annual ring were removed at intervals of about $50 \mathrm{~cm}$. Twelve cuttings were made in this manner with the aid of a sharp pocketknife, care being taken not to rupture the cambium. Each cutting was placed in a separate vial, properly labeled with the date, num- 
ber of cutting, and tree, and kept separate from the others in all the successive processes of fixing and imbedding.

The following year (I9ro) cuttings were again resumed on the same trees, as well as on four more in the same row. The manner of procedure was identical with that above described except (a) every other cutting was omitted and (b) this season the first cutting was made February 2I, the second April 2, and thereafter until the third of May. The object was to check up the results of the previous season and to make new observations. Two cuttings were also made on trees $A, B$, and $C$ on April 27, one on the north side and one on the south. For purposes of comparison, one root cutting was taken from tree III on the same date.

\section{Microscopical characters of the wood}

As is characteristic of the Coniferae; the secondary wood of Pinus rigida is entirely devoid of vessels. It consists almost entirely of tracheids with bordered pits on their radial walls. In cross-section these appear regularly arranged in radial rows, which occasionally divide as they proceed toward the cambium. In - longitudinal section they present the normal tracheid form, that is, a rectangular prism with sloping ends. The annual rings are sharply differentiated. Proceeding from the pith outward in radial direction are numerous pith rays; secondary rays arise in response to necessity; both are of the usual coniferous type. The histological characters of coniferous wood, however, have been described in detail by PenHallow (II), and the reader is referred to his excellent work for further detail.

The structure of the secondary thickening in the roots is quite closely related to that of the stem. However, there are one or two differences. The demarcation between the different rings is not so sharp. This results because the wood of the root is less dense than that of the stem. The tracheids possess wider lumina and there is less summer wood produced. In radial section the bordered pits on the walls are often biseriate, a condition which is never met with in the wood of the aerial portion. 


\section{Microscopical characters of cambium and cortex in winter condition}

\section{CROSS-SECTION}

The radial rows of tracheids in the xylem continue directly out into the cortex (fig. 9) through the cambial zone. For a time this radial arrangement is maintained, but sooner or later it becomes irregular, due to certain changes which take place. The cambial zone in cross-section appears as a number of layers of cells with comparatively thin walls. It is impossible to pick out the initial layer. Exterior to this are the sieve tubes. These have wider lumina than the cells of the cambial zone, and the walls are thickened as much as or more than those in the summer wood section of the xylem. However, they are not lignified as are the latter. Companion cells are wholly lacking. The rows of bast parenchyma are very prominent. One row with a few scattered individuals is formed each year (STRASBURGER I3), so that the thickened layers of sieve tubes are separated by thin bands of bast parenchyma. - In the outer cortex the bast parenchyma cells become gorged with starch and greatly enlarged. As a result the older sieve areas are stretched tangentially and are seen as thin bands separating the larger cells. Pith rays appear as straight lines running out into the cortex, but as they proceed radially into the cortex they soon become more or less irregular and curved. There are no crystallogenous cells such as are described by Strasburger in Pinus silvestris. Exterior to the cortex proper there is a series of corky layers which have arisen from living cells in the outer cortex, the so-called cork cambiums. Their structure is of the general type described by Strasburger (I3).

\section{RADIAL SECTION}

In radial section the cambial cells appear as prisms with sloping ends. The size varies slightly with the age. The sieve tubes have the general shape of the cambium cells from which they originate. Their radial walls are equipped with sieve plates, and these have the same location as the bordered pits on the walls of the tracheids. In radial section likewise we see to best advantage the bast parenchyma. This consists of rows of barrel-shaped cells arranged one 
above the other. There is also a change in the pith rays. The ray tracheids have given rise to ray cells, so that the pith rays consist exclusively of the latter. These as well as the bast parenchyma cells contain abundant starch.

\section{TANGENTIAL SECTION}

In order to study cambium and cortex in tangential section, a series of mounts is necessary. The same general characters are observable, but in addition it is evident that there is an entire absence of sieve plates on the tangential walls of the sieve tubes. The callus thickenings of those on the radial walls, however, are particularly noticeable with proper staining (methyl blue).

\section{Cambial awakening}

In taking up the study of xylem formation as it normally occurs in trees, one naturally begins the study before cambial activity begins. Cuttings taken at different heights from tree III on February 2I, I910, all showed in cross-section the general outline of the completed ring. Growth was not manifest in any of the sections. Each ring presented well marked areas of early and late wood. The latter in Pinus rigida is sharply differentiated, owing to its greatly thickened walls. The above statement does not hold true, however, for the wood of the first two or three years at any point in the trunk. Here there is no sharp demarcation between early and late wood. This condition is probably brought about by the fact that the main axis was elongating rapidly at this point when the ring was formed, or else, as these investigations tend to show, growth is slow in beginning in the apical shoot but progresses very fast when once started, so rapidly in fact that there is not sufficient time for the walls to thicken appreciably. In either alternative, there is a gradual thickening in the walls of the late wood of successive rings as the apical shoot progresses aloft.

The next set of cuttings were taken on April 4, I9ro, from tree III. The cambium was still in the resting condition. Figs. $x-3$ and 7-9 show the changes which occurred (figs. I-3) between April 4 and April I5. In fig. 3 growth is more advanced than in either figs. I or 2. The latter are both in the resting condition. So far 
as can be detected there is no evidence of tracheal formation. Figs. 7-9 are from cuttings made on the same individual at this time, but each successively nearer the ground. In the first two growth is in evidence, while in the last the cambium is still in the resting condition. It is evident from the photographs that in the spring of I9Io growth made itself manifest in tree III as early as April I5. Cuttings taken from trees IV and V at the same date likewise showed evidence of cambial activity. While there was no satisfactory evidence obtained the previous year as regards cambial awakening, since observations were begun too late, sections from tree II on May I3, I9I0, showed growth in such an advanced state that cambial activity must have begun fully as early the previous year.

As regards cambial awakening in trees $A, B$, and $C$, no lengthy observations were carried on; but two cuttings per tree were made on April 27, one on the north side and one on the south. At this date trees $B$ and $C$ already showed evidences of growth at breast height in both cuttings. In tree $A$ the cambium was still in the resting condition. However, tree $A$ was older and taller than the other individuals, and it is very evident that growth must have already begun in the higher parts.

The observations described above are in accord with those of other investigators. BÜSGEN (3) gives the time in general for cambial awakening for middle Germany as between the last half of April and the first half of May. R. HARTIG (7) has observed that evidences of growth are manifest in young (Io years) specimens of Pinus silvestris as early as April 20, while its appearance at the base of the older trees depended very much on external factors, such as thickness of stand, soil conditions, ground cover, etc. Buckhout (2), by means of bark measure, gives the date of growth inception in larch and white pine as the last week in April. However, as his computations were made at the base of the trees, probably growth began aloft earlier. That growth was not evidenced at the base of tree $A$ was due, according to the researches of R. HARTig ( $\mathbf{7}$ ), to at least three causes, namely (a) long trunk, (b) age, and $(c)$ shaded base. While the present investigations do not afford conclusive evidence, inasmuch as they covered but a 
period of two years, it would appear that in the vicinity of Ithaca growth began in Pinus rigida at about the same time each spring. To determine this point definitely, however, observations must needs be carried on for a period of years. That growth made itself evident in I9Io, however, as early as April I $5_{5}$ is readily apparent from the photographs.

\section{Place of cambial awakening}

The question of origin of growth is still in dispute. T. HARTIG (8) claimed that it made itself manifest in the youngest branches first and extended slowly downward. NörduINGer (Forest Botany, I874) makes the same assertion. R. HARTIG (7) appears to accept his father's statement if we are to judge from the following quotation: "Am oberirdischen Stamme. beginnt der Zuwachs zuerst in den jüngsten Trieben," etc. These three investigators, therefore, were unanimous in the opinion that the awakening of growth is earlier at the top of a tree than below.

MER (10) disputes this general assertion. According to his researches, the procedure of awakening was sensibly different in older trees. While in 25-year-old oaks, beeches, and firs, growth was first manifest in the youngest branches, in the older trees it was in evidence at the same time at the bases of the branches and even in the trunk where the roots began. From these points growth gradually extended to the intermediate regions.

Figs. 4-6 correspond respectively to those of the preceding numbers, except that a period of 19 days intervened. Comparing those of different date, we see that growth is more in evidence in every case where the cutting was taken at the later date. In figs. I and 2 we have apparently the resting condition, while figs. 4 and 5 exhibit signs of growth, the latter being more in evidence in fig. 5 . Comparing figs. 3 and 6 , it follows that there is a considerable advance in growth. In the former, at the outside, only two halfformed tracheids are to be seen, while in the latter three or four rows are present and these are of larger size. Comparing figs. I-6 as a whole, it is evident that during a period of I9 days there was an awakening of cambial activity in the apical portion, first manifest in fig. 3 on April I5. Growth first appeared in the crown of tree III 
some distance below the apical shoot, but in a period covering is days gradually spread upward and was in progress in the apical shoot on May 4, Igro.

Cuttings of May 4 corresponding to figs. 7-9 were not photographed. Examination revealed the fact, however, that growth was in progress throughout the basal portion of the trunk on that date, and had progressed to a greater extent than was evidenced on April I5.

From the above investigations it follows that growth was in progress throughout the main axis of the tree on May 4, while I9 days previous it was not in evidence in either the apical portion or the base. If $\mathrm{R}$. Hartig is right in his assertion that growth is first manifest in the branches, Pinus rigida is surely an exception to the rule. MER's investigations on young trees are in accord with Hartig's, so here likewise growth in Pinus rigida appears to present an anomaly. That HARTIG is right in his assertion that cambial activity proceeds from the base of the crown downward, investigations on trees $A, B$, and $C$ seem to give convincing evidence. Cambial activity was already in progress on both sides of the base in trees $B$ and $C$ on April 27, while both cuttings in tree $A$ on that date appeared to be in the resting condition. This is explained in that the trunk of tree $B$ was better illuminated below than that of tree $A$, while tree $C$ was but 25 years old. But at this date growth must have been in evidence in the upper portions of tree $A$, and the only reasonable hypothesis is that it had not yet reached the base, owing to poor insolation, thick bark, and age of the tree.

\section{Growth in lateral branches}

With a view of adding something further of value to the manner of growth procedure in Pinus rigida, investigations were also carried on upon certain of the lateral branches. Cuttings were taken from each year's growth until the main axis was reached. Then incisions were made $20 \mathrm{~cm}$. above and a like distance below the point where the branch joined the main axis. Growth in the branches followed the same rule as in the main axis. It commences some distance back of the apical shoot and spreads gradually in both directions. Time of awakening in the apical shoots of the 
branches, at least in the case of trees standing in the open, appears to be identical with that in the apical shoot of the main axis. Cuttings taken May 4 showed about the same amount of growth in each case.

The time of the beginning of cambial activity at the base of the branches is of interest when compared with that of the main trunk. Fig. I shows a section from the base of a limb six years old. Fig. Io is from a cutting taken from the main axis just above the branch, and fig. I 2 a like distance below. Growth is most advanced in fig. I2, present in fig. Io, but lacking to all appearances in fig. II. Cuttings taken from the limb in question showed growth in evidence to the extent of one or two tracheids (out to and including the apical shoot). It follows from the above that growth at the base of the branches is more retarded than at neighboring spots in the main axis. It proceeds more rapidly in the latter than it does in the former, so that it is often in evidence in the main axis before it makes its appearance at the base of the branches. This may be due to the more rapid rise of solutions in the trunk, although further investigation is necessary to decide that point.

\section{Rate of procedure}

Having determined the general procedure of growth in Pinus rigida, observations were next made on the rate of procedure. In order to make estimates of this, the series of cuttings of I909 on tree II were employed. There were four sets of these of twelve each. In each set the amount of wood formed for the individual section was determined as nearly as possible with a micrometer scale, and the results tabulated on a basis of roo (table I). The number of days intervening between each observation are given as well as the total gain and average gain per day; $x$ implies cutting was a failure; + signifies width at least as much as given; ? indicates apparent loss due to local growth fluctuation.

The table is of value in leading us to certain general conclusions. On May I3, the width of the new-formed ring was greatest in cuttings $4^{-6}$. It gradually dwindled in size toward the apical shoot, while below there appeared to be a decline followed by an increase. The next investigation was made on May 25, twelve days later. 
TABLE I

\begin{tabular}{|c|c|c|c|c|c|c|c|c|c|c|c|c|c|}
\hline No. & Amount & Amount & $\begin{array}{l}\text { No. } \\
\text { of } \\
\text { days }\end{array}$ & Gain & $\begin{array}{c}\text { Gain } \\
\text { per } \\
\text { day }\end{array}$ & Amount & $\begin{array}{c}\begin{array}{c}\text { No. } \\
\text { of } \\
\text { days }\end{array} \\
\end{array}$ & Gain & $\begin{array}{l}\text { Gain } \\
\text { per } \\
\text { day }\end{array}$ & Amount & $\begin{array}{c}\text { No. } \\
\text { of } \\
\text { days }\end{array}$ & Gain & $\begin{array}{c}\text { Gain } \\
\text { per } \\
\text { day }\end{array}$ \\
\hline & $\begin{array}{l}\text { May } \\
\text { I3, 'o9 }\end{array}$ & $\begin{array}{c}\text { May } \\
29 \text {, 'o9 }\end{array}$ & & & & $\begin{array}{l}\text { June } \\
3, \text {,'o9 }\end{array}$ & & & & $\begin{array}{l}\text { June } \\
\text { I }_{5},{ }^{\prime} \circ 9\end{array}$ & & & \\
\hline I & 3 & 5 & I 2 & 2 & O.I7 & 5 & 9 & 0 & 0.00 & 35 & I 2 & 30 & 2.50 \\
\hline 2 & 3 & 5 & I 2 & 2 & 0.17 & 20 & 9 & I 5 & 1. 63 & $25+$ & I 2 & 5 & 0.42 \\
\hline 3 & 8 & 8 & I 2 & 0 & 0.00 & 24 & 9 & I6 & 1. 78 & $x$ & I 2 & $x$ & $x$ \\
\hline 4 & I 2 & I 5 & I 2 & 3 & 0.25 & 40 & 9 & 25 & 2.78 & 35 & I 2 & $?$ & ? \\
\hline 5 & I 2 & 18 & I 2 & 6 & $0.5^{\circ}$ & 30 & 9 & I 2 & I. 33 & 40 & I 2 & ro & 0.83 \\
\hline 6 & I 2 & 20 & I 2. & 8 & 0.67 & 30 & 9 & Io & I. I I & 35 & I 2 & 5 & 0.42 \\
\hline 7 & 8 & I3 & I 2 & 5 & 0.42 & 40 & 9 & 27 & 3 & 40 & 12 & 0 & 0.00 \\
\hline 8 & $x$ & IO & I 2 & $x$ & $x$ & 30 & 9 & 20 & 2.22 & 38 & 12 & 8 & 0.67 \\
\hline 9 & 8 & I I & I 2 & 3 & 0.25 & 40 & 9 & 29 & 3.22 & 45 & I 2 & 5 & 0.42 \\
\hline I0 & 6 & I0 & I 2 & 4 & 0.34 & $2 \mathrm{I}$ & 9 & I I & I. 22 & 30 & I 2 & 9 & 0.75 \\
\hline II & $x$ & $x$ & I 2 & $x$ & $x$ & 25 & 9 & $x$ & $x$ & 42 & I 2 & I7 & I. 42 \\
\hline I2 & I I & 8 & 12 & ? & $x$ & $x$ & 9 & $x$ & $x$ & I7 & I 2 & $x$ & $x$ \\
\hline
\end{tabular}

Looking at the average gain per day, we see that in cutting 6 the greatest increase occurred, while above and below the amount of gain varied irregularly with the different cuttings. However, the gain in the apical shoot was but slight. Comparing the results of May 25 with those of June 3 , it is evident that, with the exception of the apical shoot, the average daily increase at the latter date was greater in every case than in the former. In other words, the tree grew faster in diameter, with the exception of the terminal shoot, during the last of May and the first of June than before that time. It follows from the table that the rate of increase varies considerably with the cutting and obeys no general law. The data of June $\mathrm{I}_{5}$, however, are most interesting. There was a decrease in the rate of growth between June 3 and June 15 , with the exception of the apical shoot. Here, on the contrary, the gain in I 2 days was 15 times as great as that of all the diameter growth previous to June 3. There was then a very marked increase in the formation of the annual ring at this point as compared with the gradual decrease in the remainder of the tree. Unfortunately, however, data are not available bearing on the rate of elongation of the apical shoot. It would appear, however, that its elongation must have been very rapid up to June 3 , so much so in fact that the increase in the width of the annual ring could not result. From June 3 to June ${ }_{5}$ the rate of elongation probably decreased appre- . 
ciably, while greater increase of wood formation resulted as a natural sequence.

Before summing up the results of the preceding paragraph, some observation on cessation of cambial activity should be given. It has long been recognized that while cambial activity makes itself manifest in many trees at about the same time, there is no relation evident in its cessation. Thus Buckhout (2) found in Larix decidua that there was little if any growth after July, while Pinus Strobus continued to form wood until well into September. R. HARTig $(6,7)$ also gives data bearing on this subject. In beech it lasts 2.5 months, in oak 4 months, in Scotch pine and Norway spruce 3 months. FrIEDRICH (see WIELER I4), on the contrary, claims that in coniferous and hard woods in general there are two periods of growth, one lasting until about the end of May, sinking until the middle of June, and reaching a maximum again in July. Complete cessation resulted by the middle of August. The majority of workers, however, unite with HARTIG in saying that cessation of cambial activity varies greatly with the species concerned.

In the present studies, the latest cuttings in I909 were made on July 6 upon tree III. At that time growth was still in progress throughout. Comparing these with cuttings taken from the same tree on February 2I of the next year, the following interesting results are obtained. Cutting 2 showed 0.5 of the ring complete, cutting 4, 0.6 , cutting 8, 0.85 . R. HARTIG (6) agrees with T. HARTIG (8) that cessation of growth begins first in the crown in trees in open stand and proceeds gradually downward. If such is the case, the data just given present an anomaly, or else growth

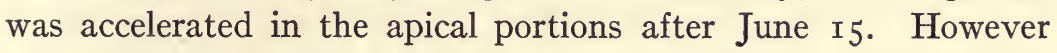
some of HARTIG's data are in accordance with that already given. For example (BÜSGEN 3), on June $2 \mathrm{I}$ the ring of an oak as compared to that of a previous year gave the following data:

At $\mathrm{r} .3 \mathrm{~m}$. height....... 0.45 complete

At $3.5 \mathrm{~m}$. height........ 0.45 complete

At $5.7 \mathrm{~m}$. height........ 0.45 complete

At $7.9 \mathrm{~m}$. height.......0.72 complete

At $12.3 \mathrm{~m}$. height........ 0.57 complete

At $14.5 \mathrm{~m}$. height......0.56 complete ( $3-4$ year branch) 
HaRTIG then obtained results comparable to the present ones; that is, at about the middle of June he observed that growth was most advanced near the middle of the tree and decreased in both directions from that point. And yet he persists in his assertion that growth ceases in trees in open stand first in the youngest branches. Such being the case, the only possible solution of the data given above is that there must have been a marked acceleration of growth in the apical portions after June $2 \mathrm{I}$ and a corresponding decrease in the parts below. Whether the same applies in the pitch pine further investigation must decide. There was an increase in radial growth in the apical shoot and at the same time a decrease below between June 3 and I $_{5}$, but that growth ceased first above cannot be deduced from the present observations.

As regards the theory advanced by FRIEDRICH concerning two periods of maximum growth in trees, little can be said. The second period if present in Pinus rigida must be the minor one, inasmuch as the ring was on an average more than half completed on June I 5 .

\section{Width of the ring}

Measurements were made from sections of tree III to determine the width of the ring at different heights. According to Hartig, in trees in open stand the amount of wood formed increases from apex to base. This may arise from one of two alternatives; either the annual ring may decrease in size owing to the increasing diameter, or the reverse may be true. The latter, he says, is but rarely the case and sometimes occurs in trees which are exceptionally well nourished, that is, those possessing a large vigorous crown. From these observations it is to be expected that in Pinus rigida the ring would increase perceptibly in width toward the base, inasmuch as the crown is as a rule not exceptionally well developed. Such was the case. At cuttings I and 4, the completed ring on February 2I, I9Io, was about the same width. At cutting 8 it was but 0.85 the size of that above, while cutting I 2 showed a still further decrease to 0.70 . It follows that in Pinus rigida, if there is such a decrease in the size of the ring from apex downward in young vigorous growing trees, the same applies with even greater force in older trees with longer axis and poorly developed crown. 
The living portion of the cortex, on the contrary, follows a law exactly the reverse. In the upper portions of the crown the cortex is necessarily thin, inasmuch as it contains a relatively small series of bast parenchyma and sieve tube areas. Below, the thickness of the cortex increases markedly, so much so in fact that it often attains $3-5 \mathrm{~cm}$. in width. The storing capacity of the cortex as a result must be greatest in the basal portions of the trunk. Assuming that food abundance alone was concerned in cambial awakening, the latter would result first below. Inasmuch as it does not, there are certainly other determining factors, chief among which is probably insolation.

Investigations on the older trees revealed a number of factors of sufficient interest to demand mention in this paper. A curious feature long known to former workers was especially prevalent. I refer to the often noted lessened density of the wood on the south side of trees. This is due to the fact that the proportion of summer wood on the north side is greater as compared with the width of the ring than on the south side. This disparity in wood formation, however, is not so marked in young individuals. The ring formation is much more regular and it is only in the older trees that the phenomenon above described is seen. As to the cause of this lessened density on the south side, no reasonable conclusion was attained in these investigations, nor has it ever been satisfactorily accounted for. It is without doubt correlated with insolation in some way, but further study is necessary to determine this definitely.

The manner of cambial awakening likewise presents an interesting study. It was observed that even on different sides of the same section a noticeable disparity often occurred. In some cases growth had proceeded to the extent of one or two partly formed tracheids, while in closely neighboring spots the cambium appeared as yet in the resting condition. Nor was one tracheid completely formed as to size before another began. Often rows of three or four small tracheids were visible, none of which had yet attained half the size of those formed first the previous year. In such cases it would appear that cell division was so rapid in the cambial region during favorable seasons that new elements were laid down before 
their predecessors had yet attained their maximum size and strength.

Double rings were often in evidence in the old trees. These might easily cause miscalculation as to age. The phenomenon of double ring formation has often been observed, especially in broadleaved trees. Here it was ascribed sometimes to partial or complete defoliation, at others to favorable or unfavorable external factors. The first assumption would not hold in Pinus rigida in this case or in general, since defoliation rarely occurs. The cause must be ascribed to external growth conditions, but what these are would be difficult to determine. That they are most prevalent in old trees is well known, and this would lead one to infer that their formation is in some manner correlated with inhibition of growth, since the effects of this are most marked on older less vigorous individuals.

\section{Secondary thickening in the roots}

Little stress was put on the study of secondary root thickening in the present investigation. Only one cutting was taken, on April 27, I910, for purposes of comparison, so that no reliable deductions can be made. At this time cambial activity was not manifest, although it must have been in process throughout the aerial portion with the possible exception of the apical shoot. T. HARTIG (8) claimed that cambial awakening in the roots is much later than in the aerial portions. He gave midsummer as the time of first inception and said it continued far into October. Whether the same applies to Pinus rigida further investigation only can decide. Suffice it to say, however, that the growth in thickness of roots must not be confused with growth in length. The latter is manifest often as early as March and continues throughout the season.

\section{Summary}

I. The histological characters of Pinus rigida present no wide variation from the normal coniferous type.

2. The secondary thickening in the root is similar to that in the stem, but differs $(a)$ in less sharp demarcation between the annual rings, $(b)$ in the biseriate character of tracheids, and $(c)$ in less density. 
3. Growth began in young 20-30-year old specimens of Pinus rigida in the vicinity of Ithaca as early as April I5. While there was no direct evidence of cambial awakening secured the previous year, sections taken at a later date showed growth in such an advanced state that it must have begun fully as early.

4. In older trees cambial awakening is sometimes retarded at the base where proper insolation is lacking.

5. There is no appreciable difference in the time of cambial awakening on the north and south sides of trees.

6. Growth began first in 20-25-year-old specimens at some distance below the apical shoot, but during a period of 19 days gradually spread upward until it reached the apex of the trees.

7. Investigations on trees $A, B$, and $C$ tend to show that growth in older individuals begins first in the crown and spreads downward. The time of its inception at the base varies with conditions of insolation, bark, etc.

8. Growth in the branches follows the same rule as in the main axis. The time of awakening in the former is almost if not absolutely identical with that in the latter.

9. Growth spreads down the main axis faster than it does along the lateral shoots.

Io. Except in the terminal shoot, growth in diameter was more rapid between May 25 and June 6. In the terminal shoot itself greatest rapidity of growth was manifested between June 6 and June $\mathrm{I}_{5}$.

II. No reliable deductions concerning cessation of cambial activity can be drawn from the present investigations.

I2. The width of the complete ring decreases from apex to base; the living portion of the cortex follows the reverse rule.

I3. A number of peculiarities already noted by others are prevalent in mature specimens. These are $(a)$ lessened density of wood on the south side of trees, $(b)$ irregularity of cambial awakening in closely neighboring parts of the same section, $(c)$ successive formation of new elements before previous ones have reached their maximum size, and $(d)$ double rings.

CoRnelt University

ITHACA, N.Y. 


\section{LITERATURE CITED}

I. BRitton, N. L., North American trees. I908. p. 3 I.

2. Buскночт, W. H., Formation of annual rings of wood. Forest Quarterly 5:259. 1907 .

3. BÜSgen, M., Bau und Leben unserer Waldbäume. I897. p. 62 .

4. Coulter, J. M., and Chamberlain, C. J., Seed plants. rgor.

5. GoFf, E. S., The resumption of root growth in spring. Wis. Sta. Rept. I898:220-228. fig. 6. I898.

6. Hartig, R., Das Holz der deutschen Nadelwaldbäume. I885. p. 35 .

7. - Anatomie und Physiologie der Pflanzen. I891. p. 262.

8. Hartig, T., Bot. Zeit. 18:829. 1858 .

9. Hastings, G. T., When increase in thickness begins in trees. Science, N.S. I2: 585 . 1900 .

ro. Mer, E., Sur les causes de variation de la densité des bois. Bull. Soc. Bot. France 39:95. 1892 .

II. Penhallow, D. P., Anatomy of the North American Coniferales with certain exotic species from Japan and Australia. Amer. Nat. 38:243. r9o4.

I2. Reuss, H., Beitr. zur Wachstumsthätigkeit des Baumes nach praktischen Beobachtungsdaten des laufenden Starkenzuwachsganges an der Sommerrinde. Forstlich. Zeitschr. 2:145. 1893.

13. Strasburger, E., Die Angiospermen und die Gymnospermen. I879.

14. Wieler, A., Úber die Periodizität im Dickenwachstum des Holzkörpers der Bäume. Bot. Zeit. 56:262. I898.

\section{EXPLANATION OF PLATES XXIV AND XXV}

FIG. I.-Cutting taken from apical shoot of tree III April I5, r910; cambium in the resting condition; $\times 50$.

FIG. 2.- Same, but cutting taken about $1 \mathrm{~m}$. from the apex; cambium in the resting condition; $\times 50$.

FIG. 3.-Same, but cutting taken about $2 \mathrm{~m}$. from the apex; growth in evidence to the extent of one or two partly formed tracheids; $\times_{50}$.

Fig. 4.-Cutting taken from apical shoot of tree III May 4, r9Io; growth just beginning at $A$; compare with fig. I; $\times_{50}$.

FIG. 5.-Same, but cutting taken I $\mathrm{m}$. from the apex; growth slightly more advanced; compare with fig. $2 ; \times 50$.

Fig. 6.-Same, but cutting taken from the apex; growth in evidence to the amount of 3 or 4 tracheids; compare with fig. $3 ; \times 50$.

FIG. 7.-Cutting taken from tree III April I5, r9ro, about $3 \mathrm{~m}$. from the apex; growth in evidence to the extent of one or two partly formed tracheids; $\times 50$.

Fig. 8.- Same, but cutting taken about $4 \mathrm{~m}$. from the apex; growth in evidence to about the same extent as in fig. $7 ; \times 50$. 

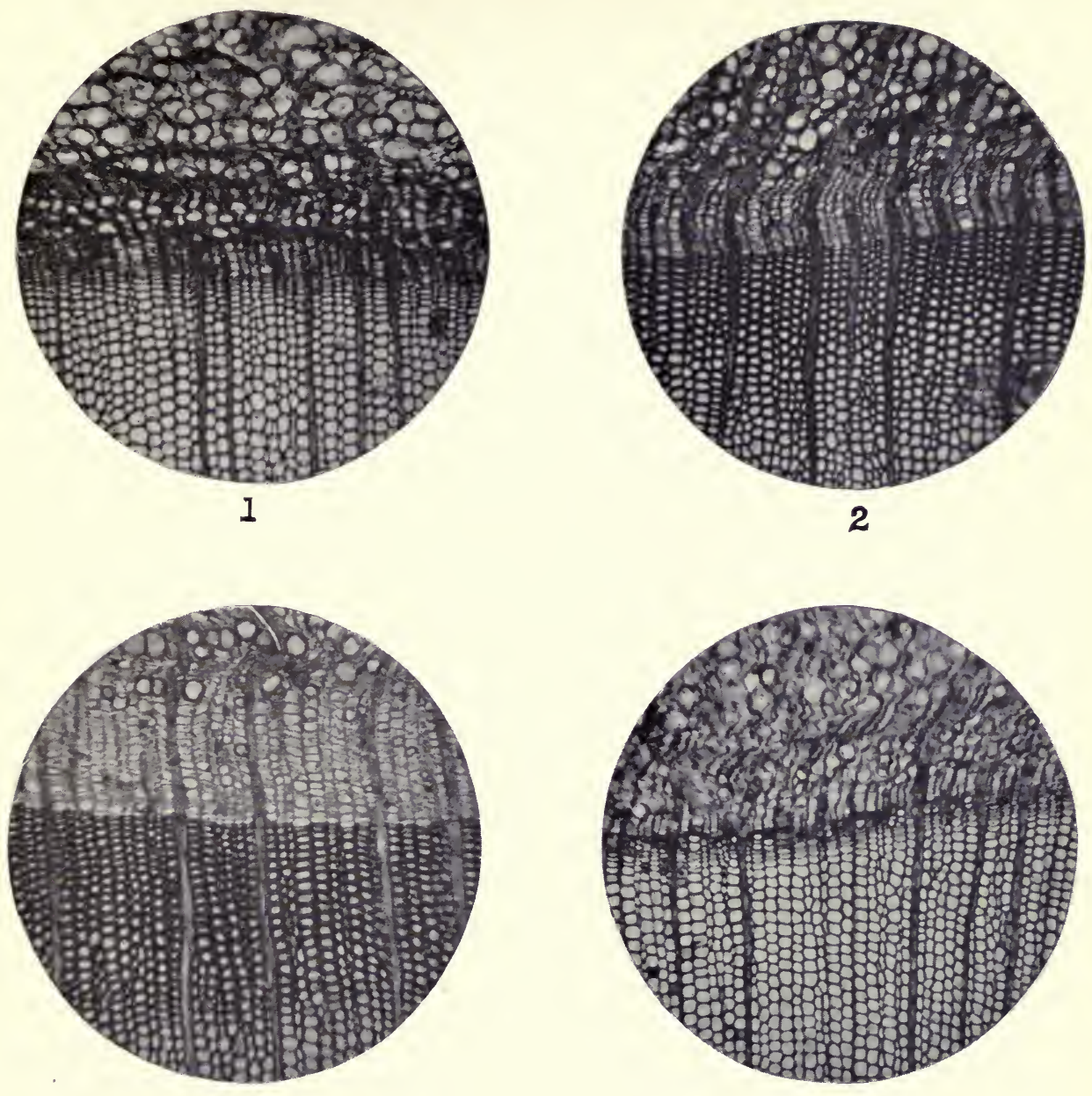

3

4

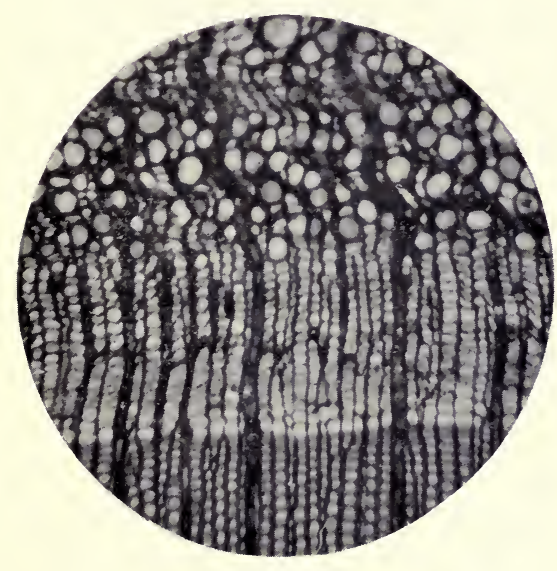

5

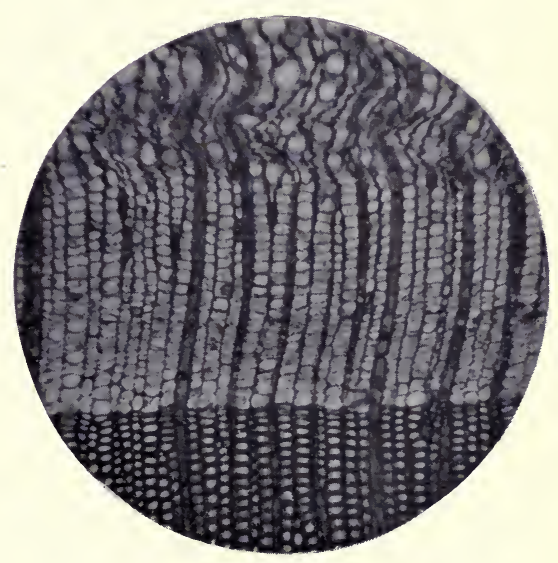





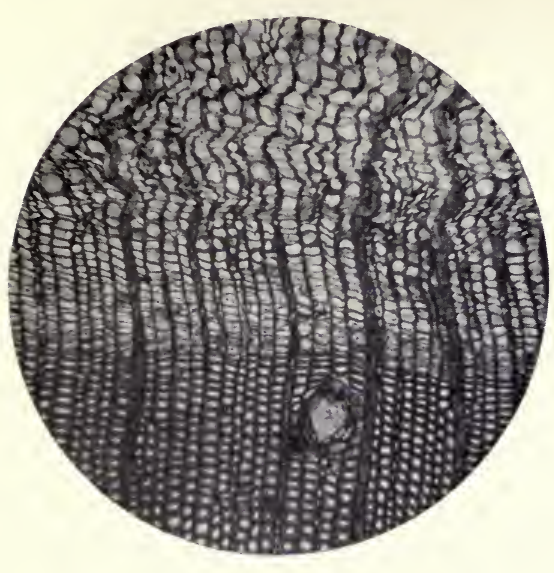

7

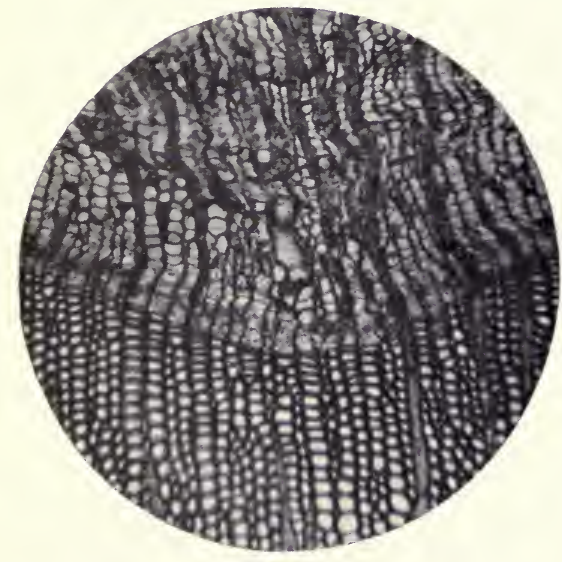

9

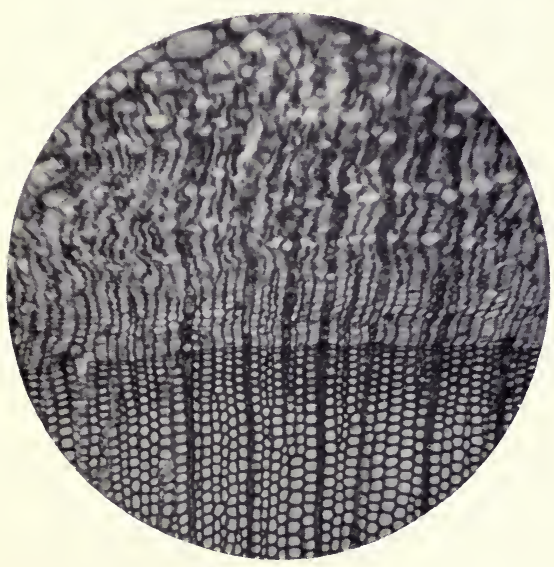

II

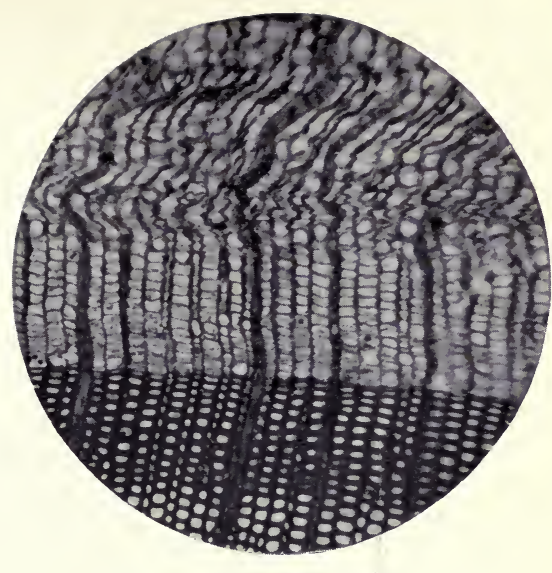

8

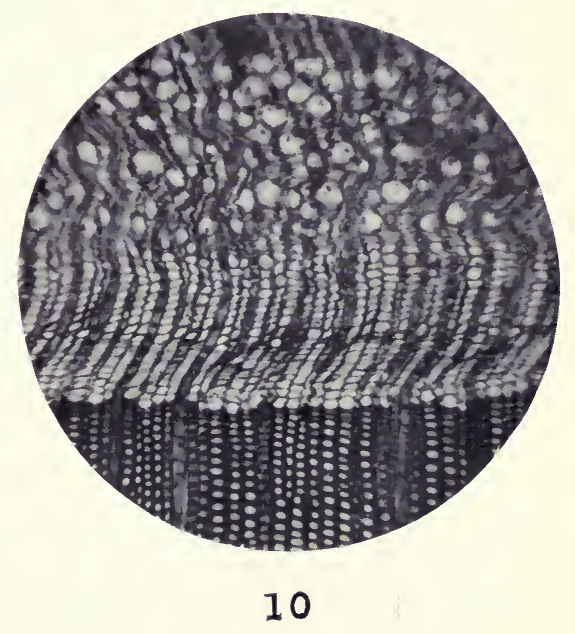



FIG. 9.-Same, but cutting taken about $5 \mathrm{~m}$. from the apex; cambium in the resting condition; $\times 50$.

FIG. ro.-Cutting from main axis of tree VI April 22, I9ro, at a distance of $3 \mathrm{~m}$. from the apex; growth in evidence to the extent of several rows of partially formed tracheids; $\times_{5}$.

FIG. II.-Same, but cutting from the base of a lateral branch which entered the main axis $20 \mathrm{~cm}$. below cutting shown in fig. IO; no growth in evidence; $\times 50$.

FIG. I2.- Same, but cutting taken $40 \mathrm{~cm}$. below that in fig. I0; growth in evidence to the extent of several rows of tracheids; $\times_{50}$. 



\title{
Walter Mulford
}

\section{A STUDY OF PIÑON PINE}

\author{
F. J. PHILLIPS \\ GENERAL DISTRIBUTION
}

No other tree species of the southern portion of the Rocky Mountain region presents more difficult problems in maintaining and reproducing the natural stands than does the piñon pine (Pinus edulis). It ranges from northern Mexico to eastern Utah, and Colorado Springs, Colorado. In an east-and-west direction it extends from the hills of western Texas to California. Along the northern and eastern borders of its range it is shrublike and of botanical importance only. In southern Colorado, Arizona, and New Mexico, it has a great economic and silvicultural importance, which will steadily decrease unless measures are taken to prevent excessive utilization.

It is commonly found in mixture with the one-seeded juniper (Juniperus monosperma) in the northern part of its range and with the alligator juniper (Juniperus pachyphloea) and one-seeded juniper in the south. Throughout its distribution it is associated with western yellow pine (Pinus ponderosa) and the scrub oaks (Quercus Gambelii and Quercus acuminata), often forming with these species a transition belt between stands of juniper and western yellow pine. Occasionally it is found with stunted Douglas fir (Pseudotsuga taxifolia). In association with the junipers, it forms the distinct woodland type so characteristic of New Mexico and Arizona, which in this region covers a more extensive area than any other forest type, and in which the piñon is decidedly the most important tree. It is occasionally seen in pure stands over small areas, but this is rare.

\section{LOCAL OCCURRENCE}

The tree thrives best at a general elevation of 1650 to $235^{\circ} \mathrm{m}(5400$ to 7700 feet) on moderate to steep mountain slopes and over broad, level, or sloping mesas. Small isolated specimens were found up to an elevation of 2600 and $275^{\circ}$ (8500 and g000 feet), while occa- 
sional specimens may be found even higher than this. The best stands are found on coarse gravel, gravelly loam, or a coarse sand, of $\mathrm{I} .5^{\mathrm{m}}$ ( 5 feet) or more in depth, on which humus and ground cover are almost entirely lacking. The species often occurs on rocky areas, where the soil is only 15 to $30^{\mathrm{cm}}\left(6-\mathrm{I}_{2}{ }^{\text {in }}\right)$ in depth, and frequently it is found growing in rock crevices. It is one of the first trees to gain a foothold on the lava overflows which are known throughout the southwest as mal pais. This rock in its disintegrated form supports fair tree growth, but even before disintegration has progressed very far, the junipers and piñon may be found encroaching upon it.

Another encroachment form of the piñon is to be found on small mounds which rise 0.6 to $3^{\mathrm{m}}$ ( 2 to Io feet) above the general level of the desert-like tableland at approximately $1500^{\mathrm{m}}$ (5000 feet) elevation. On such islands as these, the piñon and one-seeded juniper take possession and maintain a limited growth. The same feature is noted at the bases of the hill and mountain slopes which bound these tablelands. This remarkably distinct tension line seems to be due to a greater soil porosity, less grass growth, and a smaller alkali content, which are manifest in slightly higher elevations. The distribution of these trees on such small mounds and limited in such a distinctive manner presents an ecological problem for future investigation.

On slopes where site conditions are favorable for western yellow pine, the piñon usually occupies the south and west aspects. Where conditions become less favorable, it occupies the north and east slopes, while the south and west slopes are bare or nearly so. This ability to stand poor conditions is also shown on a large number of mountain slopes ranging from 2830 to $3{ }^{1} 35^{\mathrm{m}}$ (6000 to 7000 feet) in elevation, where scattering Douglas fir, of scrubby growth and badly affected with witch's broom, is found in the cañons; western yellow pine on the middle slopes; and piñon on the ridges and upper slopes, where the soil is scant and the soil moisture low.

A distinctive peculiarity was observed between Servilleta and Taos, New Mexico, in an open stand of the species in which approximately two-thirds of the trees have constricted bases at the surface of the ground. This constriction amounted to an average of $19^{\mathrm{mm}}\left(0.75^{\mathrm{in}}\right)$ 
in radius, but was occasionally. noted where it amounted to $38^{\mathrm{mm}}$ $\left(\mathrm{I} \cdot 5^{\text {in }}\right)$. Such a constriction is often seen on individual trees in nearly any stand, but in no other case was it found to be a stand as characteristic as it was near Servilleta.

Piñon is also resistant to severe climatic conditions, since it will succeed over severely exposed slopes where the average annual precipitation is less than $33^{\mathrm{cm}}\left(\mathrm{I} 3^{\text {in }}\right)$ and where evaporation and transpiration are high because of the semi-arid climate, the large amount of sunshine, and the prevalence of winds. In this respect it is undoubtedly the most resistant pine in the southwest. However, it prefers a slightly greater precipitation and areas less exposed to the wind. An example of the unfavorable influence of strong winds and a close-textured soil was noted in the vicinity of Fort Stanton, New Mexico, where a level plateau of nearly $8^{\mathrm{km}}$ (5 miles) in length did not support a single tree, while similar plateaus on all sides, with less wind sweep and a coarser soil, showed luxuriant growth of both the piñon and the juniper. The tree does not live as long as the junipers, and in general is less resistant to unfavorable climatic conditions. In the drought which occurred in New Mexico from 1889 to 1904 , piñon suffered considerably more than the junipers. Many mixed stands were observed in New Mexico and southern Colorado in which 75 to 95 per cent. of all dead trees were piñon. In the frost which occurred in April, I907, piñon was affected, while the junipers resisted practically all injury. In the wet freezing snow of October, 1906, which caused immense damage to the forests of the southwest, fewer branches were broken from the piñon than from the brittle junipers.

The tree is also more resistant to disease than most of the conifers with which it associates. It is much less affected by the so-called false mistletoe (Razoumofskya) than is the western yellow pine and the junipers. It has fewer insect enemies than the western yellow pine, and is not affected by the witch's broom as is often the case with Douglas fir in the southwest.

\section{TOLERANCE AND FORM}

Piñon is distinctly an intolerant tree. During its seedling stage it prefers a moderate shade, and hence reproduces best under the 
shade of older trees. After the seedling stage is passed it prefers the open, and is one of the most intolerant of forest trees. This gives an orchard-like appearance to most stands of this species. Occasionally stands of 0.7 density were noted, although few stands have more than 0.6 density.

On the best sites the trees reach a maximum height of $\mathrm{I} 2$ to $\mathrm{I} 3 \cdot 7^{\mathrm{m}}$ ( 40 to 45 feet) and a diameter of 60 to $75^{\mathrm{cm}}$ (2 to 2.5 feet) at breast height, but ordinarily the mature individuals range from 3 to $10.5^{\mathrm{m}}$ (Io to 35 feet) in height and from I 5 to $45^{\mathrm{cm}}$ (O. 5 to I . 5 feet) in diameter. A difference in development was apparent on different sites. On exposed sites the tree is globular, very scraggly when mature, and has little or no clear length. On favorable sites trees in the open have a very short clear length and a fairly regular globular or eggshaped crown. If grown in stands, the trees have a greater clear length and a flat or vase-shaped crown. Young trees on favorable sites are conical or globular in shape and usually very regular in form.

On the most exposed sites, shrublike trees were found which were fifty to eighty years old, and only 1.8 to $3^{\mathrm{m}}$ (6 to 10 feet) in height, with a crown diameter reaching a maximum of two to four times the height of the tree. On such trees it was impossible to distinguish the leader from the branches, and the general appearance of the tree was much like that of the dwarf mountain pine (Pinus monticola). The foliage is more densely clustered on these dwarf trees than it is on trees in the open, with shorter and apparently thicker leaves. Practically all trees, whether growing on poor or good sites, are characterized by dead and half-dead branches, which are retained on the tree for several years. This is characteristic of nearly all species in the southwest and is due to the small amount of growth that is made, the necessity of retaining only a small amount of living tissue, and the dry nature of the climate, which allows the retention of dead branches for a longer period than would a moist climate. In exceptional stands, such as occur to the west of Servilleta, New Mexico, where a clear length of 4.5 to $7.6^{\mathrm{m}}$ ( $\mathrm{I} 5$ to 25 feet) is not exceptional, the branches are shed largely because the density of stand prevents the formation of as large branches as are found in those trees which enjoy full sunlight. 


\section{WOOD}

Piñon wood is moderately heavy for the pines. It is used extensively for fuel and has been limitedly used for fence posts, telephone poles, corral posts, mine lagging, railroad ties, charcoal, and inferior lumber. Some authorities have recommended its use for fence posts, but this is to be seriously questioned as it has little durability in contact with the soil, and even the natives are discarding it for such use. It may be rendered valuable, however, by the use of preservatives. The tree is remarkable in its fuel value, and its use for such a purpose should be greatly encouraged. It is a common practice to cut branches or trees after they have been dead about two years. If cut before this time, the wood has not seasoned sufficiently to burn readily. If cut after this time, it has usually deteriorated to some extent. As a hearth fuel, it is not surpassed by another conifer and by only few hardwoods. It starts to burn readily, retains fire for a considerable length of time, gives a large amount of heat, and does not throw sparks. Since open fires are very common in this region, this wood serves an excellent purpose. Sample acres which have been clear cut have given a yield of 180 to $360^{\mathrm{cu} m}$ per hectare (20 to 40 cords per acre), while extensive stands have averaged 90 to $108^{\mathrm{cu} \mathrm{m}}$ (Io to I2 cords).

\section{FRUIT}

The young cones are dark red and occur in elongated clusters. The pistillate form is easily distinguished by short stalks. Both sorts are very plentiful in seed years, but are scarce during other years. The mature cone is short, top-shaped, I9 to $50^{\mathrm{mm}}$ ( 0.75 to $2^{\text {in }}$ ) long and often as broad as long. The cones open on the tree and are covered by a large amount of free resin, which makes them difficult to handle. They often occur on trees only 0.9 to $\mathrm{I} .2^{\mathrm{mm}}$ ( 3 to 4 feet) in height, which are ten to twenty years old, but the best crops are borne on mature trees which produce 35 to $280^{1}$ (I to 8 bushels) of cones; each cone contains two to thirty seeds, with an average of ten to twenty seeds. The trees have been known to yield $336^{\mathrm{kg}}$ of seed per hectare (300 pounds per acre), while a much larger area has been known to produce an average of $73^{\mathrm{kg}}$ per hectare $(65$ pounds per acre). 
Seed years usually occur at five-year intervals, but have been reported at shorter intervals than this. The seed is well rounded at the base, tapering with prominent ridges to an acute point. It is usually dark brown on the lower side, with more or less mottled orange yellow on the upper side, 9 to $\mathrm{I} 2.5^{\mathrm{mm}}\left(0.375\right.$ to $\left.0.5^{\text {in }}\right)$ long, 6.5 to $9^{\mathrm{mm}}\left(0.25\right.$ to $\left.0.375^{\text {in }}\right)$ broad, with a thin shell which cracks most easily along the line of the most prominent ridge. The seed wings are about one-half the length of the seed, easily detached, and of no practical use in seed distribution. The seeds usually have a high percentage of infertility, which varies from 5 to 20 per cent., but in one case went as high as 85 per cent. Poor seeds are often lighter in color than good seeds. Germination power is lost very readily, which necessitates special storing when they are to be used for artificial planting, and good site-conditions when the stands are to be reproduced naturally. It is a matter of note that the seeds from the northern portion of the range are usually considered better than those from the south. Five samples collected in various localities gave the following results:

\begin{tabular}{c|c|c|c|c|l}
\hline \hline $\begin{array}{c}\text { No. per } \\
\text { pound } \\
\text { 453.6 }\end{array}$ & $\begin{array}{c}\text { Percentage } \\
\text { viable; } \\
\text { knife test }\end{array}$ & $\begin{array}{c}\text { Percentage } \\
\text { viable; } \\
\text { water test }\end{array}$ & $\begin{array}{c}\text { Percentage } \\
\text { viable; in } \\
\text { greenhouse }\end{array}$ & $\begin{array}{c}\text { Percentage } \\
\text { viable; } \\
\text { in open }\end{array}$ & \multicolumn{1}{|c}{ Where collected } \\
\cline { 1 - 2 } & 87.2 & 84.0 & 82.2 & 75.6 & Ft. Bayard, N. M. \\
2215 & 89.1 & 86.6 & 80.3 & 69.2 & Tres Piedras, N. M. \\
I810 & 91.2 & 86.0 & $78 . \mathrm{I}$ & 70.4 & Ft. Garland, Col. \\
1950 & 92.7 & 88.5 & 81.3 & $7 \mathrm{I} .0$ & Ft. Garland, Col. \\
I520 & 99.2 & $97 . \mathrm{I}$ & 96.4 & 90.3 & Lincoln, N. M. \\
\hline
\end{tabular}

Weevils sometimes affect the seed before the cones open. Birds and rodents eat the seed extensively, and stores are made by mountain rats which were found to contain a maximum of 35 to $7 \mathrm{O}^{\mathrm{l}}$ (I to 2 bushels) of clean seed. Ants are known to eat seed, especially at lower levels. In the early days, the Indians and Mexicans used the piñon as a staple article of food. At present, it is gathered in immense quantities and sold as a delicacy. It is eaten most extensively in and about the region where the tree grows naturally, but large amounts are being sold at fruit stands throughout most of the United States. To prevent the seeds from spoiling and to retain flavor, they are usually baked immediately after being gathered. 
Most of the seeds are collected by Mexican women and children, who usually spread a sheet or blanket on the ground and then shake or pound the tree and its branches until the seeds fall from the open cone. Later in the season, the seeds are picked up by hand from the ground beneath the trees. In the best part of the seed harvest, enough are gathered by single families to be sold by the grain bag full or the wagon load. Since the Mexicans take almost no precautions against the spreading of smallpox, it is said that the worst ravages of the disease occur during a seed year of the piñon. Single dealers have been reported as having bought 9000 to $2 \mathrm{I}, 500^{\mathrm{kg}}(20,000$ to 50,000 pounds). The delicate flavor of the seed makes it a favorite, and an extensive market is being rapidly developed for it. During seed years the native collectors sell it at the rate of five to fifteen cents per pound, according to the ease of collecting the seed and the proximity of the market, while dealers in many of our cities sell the seed at a rate of forty to sixty cents per pound.

\section{REPRODUCTION}

Natural reproduction is limited because of the infrequency of seed years, unfavorable climatic conditions, infertility of seed, rapidity with which the seed loses its germination power, loss of seed eaten by rodents, birds, and man, and unfavorable site-conditions. Grazing interests are also a factor in limiting the reproduction of the species, since sheep, cattle, and goats are grazed throughout its entire distribution. It is apparent to even the casual observer that extremely large areas are not reproducing themselves, yet owing to the difficulties of site and the methods by which the tree may be reproduced, the problem of reproduction is an extremely difficult one, and one for which, at the present time, no adequate solution can be offered.

\section{FUTURE MANAGEMENT}

From the nature of the stand in the southwest, it is apparent that clear cutting would not be an advisable system, because of the exposure of the site and the difficulties of restoring the stand. On the other hand, the large amount of seed consumed by man and other agencies makes natural seeding exceedingly difficult, and even though grazing and fire are entirely eliminated, it is doubtful if satisfactory reproduc- 
tion will be secured in even a bare majority of sites. Until the problem of reproduction is more thoroughly worked out, the policy should be to remove only the dead and dying piñon trees for fuel, thus allowing a careful management without encroaching seriously upon the natural stands as is being done at the present time. It would seem from the nature of the site that the stand could be made to succeed best by the selection system, consisting of the removal of the dying trees. The sale of this fuel with that of a large portion of the seed should furnish a moderate income. This production would be low, as contrasted with high-type coniferous forests in other regions, but when consideration is given to the value of this species for fuel and seed, the question of immediate returns is a minor one.

UNIVERSITY OF NEBRASKA 


\section{THE BOGS AND BOG FLORA OF THE HURON RIVER VALLEY}

A thesis Submitted to THE FACUlty of the UNiversity of MICHIGAN FOR THE DEGREE OF DOCTOR OF PHILOSOPHY

By EDGAR NELSON TRANSEAU

Ferry Fellow in Botany 
[Reprinted from the Botanical Gazette 40:35I-375, 4I8-448. 1905, and 4I: I7-42. 1906.] 


\section{TABLE OF CONTENTS}

I. The Huron River valley . . . . . . . . . . $35 \mathrm{I}$

Physiographic features . . . . . . . . . . 35I

Physiographic history . . . . . . . . . . . . . 353

Forests . . . . . . . . . . . . . . . . 355

Meteorological conditions . . . . . . . . . . 356

II. The bogs : their development and ecological conditions . . . 360

Physiographic origin of the lake and bog basins . . . . . 360

Bog and lake vegetation . . . . . . . . . . . . 362

The processes involved in peat formation . . . . . . . . 367

The physical and chemical properties of peat . . . . . 372

The bog as a habitat for plants . . . . . . . . . . $4 \mathrm{r} 8$

A. Physical factors . . . . . . . . . . . . . $4 \mathrm{I} 8$

r. Wind . . . . . . . . . . 418

2. Temperature . . . . . . . . . . . 419

3. Texture . . . . . . . . . . . . 422

4. Mechanical properties . . . . . . . . 423

5. Diffusion properties . . . . . . . . . . . . 423

6. Water capacity . . . . . . . . . . 424

7. Osmotic pressure . . . . . . . . . . . . 424

B. Chemical factors . . . . . . . . . . . . . . . 425

I. Ground water . . . . . . . . . . 425

2. Acidity . . . . . . . . . . . 426

3. Food material . . . . . . . . . . . . 427

C. Biotic factors . . . . . . . . . . . . . 428

III. The bog-plant societies . . . . . . . . . . . . . 429

West lake . . . . . . . . . . . . 430

First Sister lake . . . . . . . . . . . . . 432

Bog north of Delhi . . . . . . . . . . . . 436

Bog near Oxford, Oakland county . . . . . . . . . . 439

The Delhi muskeags . . . . . . . . . . . . . . 44I

Bog on Carpenter road . . . . . . . . . . . 44I

The Chelsea bog . . . . . . . . . . . . . . . . . 444

General consideration of the bog flora . . . . . . . . 447

Vol. $4 \mathrm{I}$

IV. The ecological characteristics of the bog flora and their causes . . I 7

Experiments . . . . . . . . . . . . . 22

Water cultures . . . . . . . . . . . . . 24

V. Summary . . . . . . . . . . . . . . . . 34

Bibliography ............. . . 40 



\section{THE BOGS AND BOG FLORA OF THE HURON RIVER VALLEY.}

Edgar Nelion Transeat.

(WITH SIXTEEN FIGURES)

\section{The Huron River valley.}

PHYSIOGRAPHIC FEATURES.

The Huron River valley, to the botanical survey of which the present paper forms the sixth contribution, is located in the southeastern part of Michigan. As indicated in fig. I, the valley embraces parts of five counties.

Throughout, its surface forms are of glacial origin and, with the exception of the immediate borders of the river, have undergone but slight modification since glacial times. Perhaps its most striking topographic features are the rough morainic hills of its upper and middle courses, and the gently undulating plain of its lower course.

The river has its source in west-central Oakland County in Big Lake, 9 miles $\left(\mathrm{I} 4 \cdot 5^{\mathrm{km}}\right)$ southeast of Holly and approximately 40 miles $\left(64^{\mathrm{km}}\right)$ northwest of Detroit. Starting with an elevation of $95^{\circ}$ feet $\left(290^{\mathrm{m}}\right)$, after a course, extending for 50 miles $\left(80^{\mathrm{km}}\right)$ generally southwestward and then for another 50 miles $\left(80^{\mathrm{km}}\right)$ southeastward, it empties into Lake Erie at an altitude of 573 feet $\left(\mathrm{I} 75^{\mathrm{m}}\right)$ above tide. As is common in areas of glacial deposition, the topography of the drainage basin of the Huron has little of the appearance úsually suggested by the term "valley." The upper two-thirds of its course is a winding depression among morainic knobs, lake basins, abandoned glacial drainage channels, and sand plains. Here the river is characterized by long reaches and occasional slight riffles. At intervals it broadens into stretches of lake-like character, as is illustrated by such bodies of water as Commerce, Taylor, Strawberry, Whitewood, and Bass Lakes, each with an area of one-fourth to one-half a square mile (65-1 30 hectares). The river margin is usually low and swampy.

Its tributaries enter it at every angle, and bring to it the drainage of hundreds of lakes and swamps. Most of these lakes are small, I905] 
occupying areas of an acre (half a hectare) or more, but there are several of considerable size. Portage and Whitmore ${ }^{\mathrm{I}}$ Lakes occupy one and one-fourth to one and one-half square miles (325-390 hectares), while Union, Straits, Four-Mile, Ore, Independence, etc.

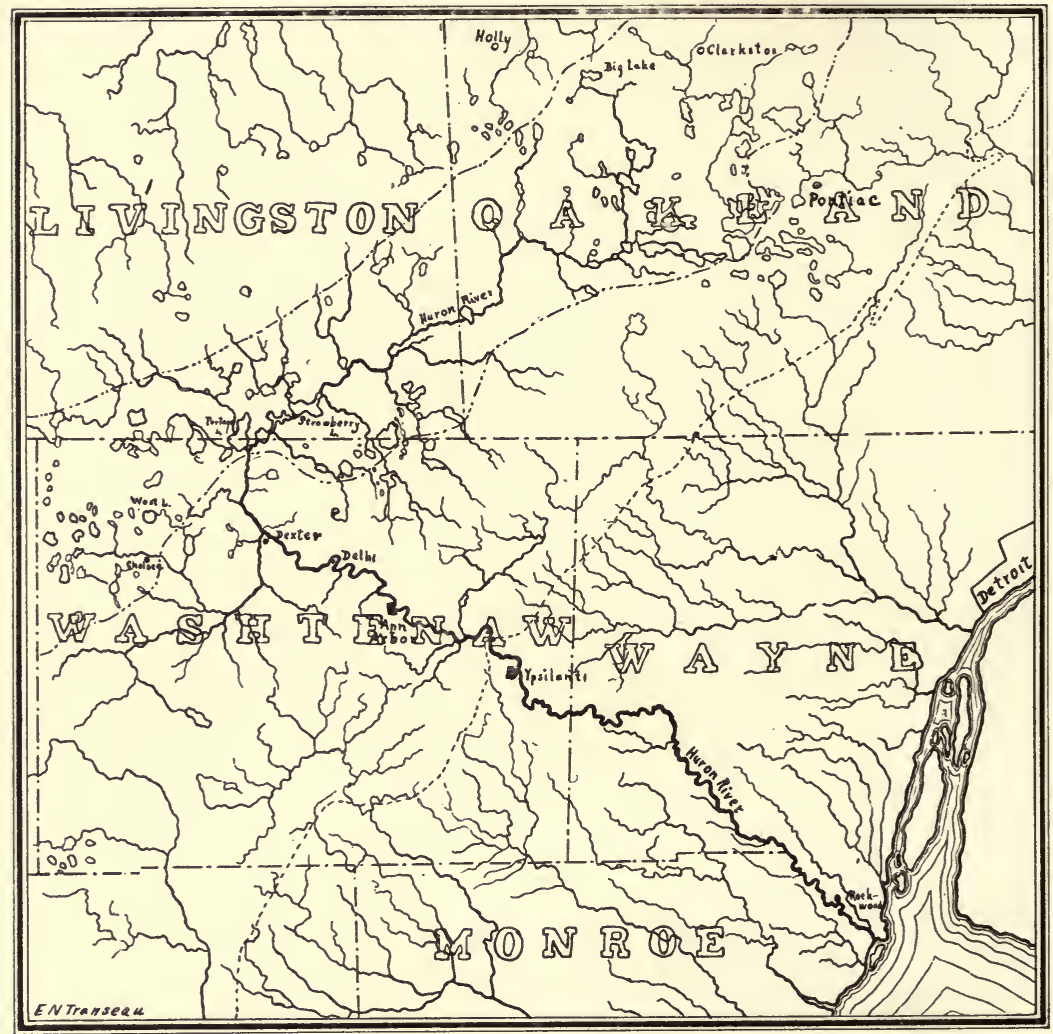

FIG. I.-Map of the Huron drainage basin. The boundaries of the interlobate moraine are shown by the lines -... The boundary between the clay morainic belt and the lake plain is marked by the line - - - -

cover a fourth to half a square mile $\left(65^{-1} 30\right.$ hectares $)$. A very large percentage of the tributaries lie in flat-bottomed depressions whose surface approximates the ground-water level, consequently producing thousands of acres of swamp and marsh land. Everywhere occur small undrained depressions, some well above the average groundwater level, others containing lakes and bogs. It is also worthy of

I Not connected with the Huron River by surface drainage. 
note that a large part of the surface drained by the Huron and its tributaries, before it makes the great bend to the southeast below Portage lake, is made up of sand and gravel, composing and accompanying the Saginaw-Erie interlobate moraine. It is, a region of steep hills, with occasional dry plains, everywhere penetrated by lakes and swamps.

The country which the river next crosses, beyond the great bend, for a distance of 20 miles $\left(3^{\mathrm{km}}\right)$ is composed of glacial till plains and clay moraines-a belt extending NE-SW, approximately parallel to the interlobate moraine. Here, although the hills are well marked, the slopes are more gradual and the basins broader. The river is bordered by banks several feet in height, and seldom attains a width of 150 feet $\left(50^{\mathrm{m}}\right)$.

The last 30 miles $\left(5^{\mathrm{km}}\right)$ of the Huron River traverses a meandering course sunken from 50 feet $\left(\mathrm{I} 5^{\mathrm{m}}\right)$ at Ypsilanti to 25 feet $\left(7 \cdot 5^{\mathrm{m}}\right)$ at Rockwood below the surface of a glacial lake plain sloping gently southeastward from the morainic belt just described, to the western shore of Lake Erie. The soil is here composed of sand, sandy loam, and-in the vicinity of the lake-clay; the only topographic features aside from the sunken water courses being the several beach ridges and dunes marking the successive stages in the lowering of the glacial lakes, forerunners of the present Lake Erie.

There are, then, three natural divisions of the Huron drainage basin: (I) the loose-textured rough interlobate moraine; (2) the clay morainic belt lying to the southeast of it; (3) and the low-lying plain extending to Lake Erie. Each implies important differences in the way of bog formation and provides edaphic factors which determine to a large extent the nature of the dominant forest covering.

\section{PHYSIOGRAPHIC HISTORY.}

The history of these topographic features is for the most part bound up with the retreat of the ice at the close of the last (Wisconsin) glacial epoch. A topographic map of the region lying between Lakes Michigan and Erie shows that the morainic hills so characteristic of the Huron basin are part of a belt of similar physiography extending from northern Indiana well up into the "thumb" of lower Michigan (fig. 2). This belt of glacial deposits is directly connected with the 
development of reentrant angles along its crest, as the great continental ice sheet ${ }^{2}$ became more and more differentiated into lobes during its retreat $\left(\mathbf{5}^{2}, \mathbf{1} \mathbf{3}\right)$. In northern Indiana it marks the first areas uncovered, as the mass of ice, pushed forward from the basin of Lake Michigan, separated from that originating in the Lake Huron and Lake Erie basins.

When the Huron River basin was reached, the Saginaw lobe had been developed and lay over the northwestern part, while the HuronErie lobe covered all of the territory southeast of the interlobate

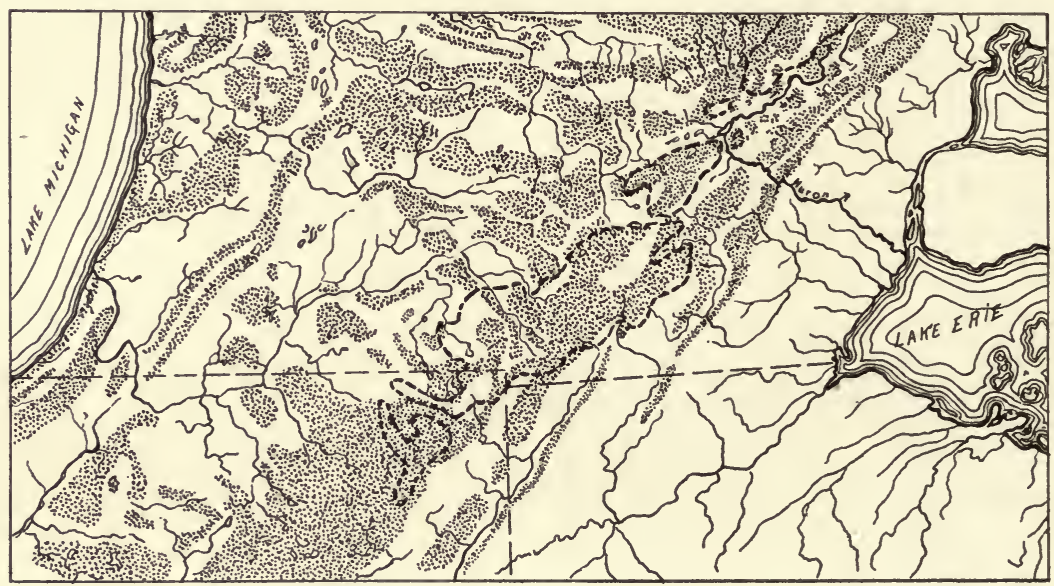

FIG. 2.-Map of southern Michigan, northern Indiana, and northern Ohio, showing "moraines with strong expression." After Leveret, U. S. Geol. Surv. Mon. 4I, plate 2. The irregular dotted lines mark the rooo-foot (300m) contour.

moraine. The first portion of our area to be uncovered is the triangular gravel outwash apron extending southwestward from Sugarloaf Knob. This was the beginning of the Huron River. Kavanaugh Lake then lay just under the edge of the Frie ice, and Crooked Lake uccupied a similar position on the southern border of the Saginaw lobe. As has been recently determined by Mr. FrANK LEVERETT, of the U. S. Geological Survey, the subsequent history of the Huron drainage is most remarkable.

The waters from the glacial drainage at first flowed generally westward, reaching the Kalamazoo River near Albion, thence to the St. Joseph at Three Rivers. At South Bend, Indiana, it crossed ${ }^{2}$ For general map see no. 55, p. 4 Ir. (Bibliography at close of this paper.) 
to the Kankakee River, and reached the Mississippi by way of the Illinois.

As the reentrant extended itself further to the northeast, another channel was opened for the Huron drainage westward past Pinckney into the Grand River, and from there to Battle Creek and the Kalamazoo River. Below the city of Kalamazoo it cut across to the Paw Paw River, and reached the Mississippi by way of Lake Chicago.

When the ice of the Erie lobe had retreated as far eastward as Ann Arbor, and all of the interlobate moraine had been uncovered, a third outlet for the waters of the Huron was opened by way of Clinton and the Raisin River, which at that time emptied into glacial Lake Maumee at Adrian (32, pl. 20). This lake was drained by the Wabash River into the Mississippi.

As soon as the ice margin passed the clay morainic belt already described, the Huron reached Lake Maumee at Ypsilanti by way of its present channel. But Lake Maumee had meanwhile changed its outlet to the northward, its drainage going by way of Imlay (53) to the Grand River, Lake Chicago, and the Mississippi (32, pls. $21,23,26)$.

Later the Erie basin was entirely freed of ice, and its water for the first time flowed eastward into the Ontario basin (glacial Lake Iroquois), and thence by way of the Mohawk to the Hudson. With the clearing of the St. Lawrence channel the present system was inaugurated.

Aside from the physiographic interest connected with their early history, these glacial druinage channels are of distinct biological, interest. They furnish continuous lowland habitats extending in all directions. In so far as they are represented by broad, open valleys, and connect with tributaries of the northern Ohio valley, they provide important highways for the dispersal of southern rivervalley species.

FORESTS.

The three topographic divisions already described exhibit marked differences in their forest aspect. On the lake plain we find the richest and most mesophytic of the forest types. This lowland habitat is a continuation of the northern Wabash valley, and it is not surprising that its flora should be of much the same character. Here 
we find the greatest variety of tree species, among which are Fagus atropurpureus, Quercus rubra, Ulmus americana, Platanus occidentalis, Acer saccharum, Tilia americana, Acer saccharimum, Fraxinus americana, Gleditsia triacanthos, Liriodendron tulipifera, Gymnocladus dioica, Cercis canadensis, Asimina triloba, and Celtis occidentalis.

The clay morainic area is dominated by Quercus rubra, Q. alba, $Q$. velutina, Hicoria ovata, H. glabra, Acer rubrum, Ulmus americana, and Quercus macrocarpa.

In the region of the interlobate moraine the disappearance of the more mesophytic forms is quite marked. The forest is there largely composed of Quercus coccinea, $Q$. macrocar $p a, Q$. velutina, $Q$. alba; and as we go northeastward these become associated with Pinus strobus. Quercus prinoides forms a characteristic shrubby growth along the roadsides and in waste places.

Such is the forest background in which are set the thousands of acres of bog and swamp, and to which the groves of Larix laricina exhibit a marked contrast. These tamarack areas are to be seen on all sides in the region of the interlobate moraine; they are quite common in the clay morainic belt, but are practically wanting on the lake plain.

As one follows along the morainic country from northern Indiana into the "thumb"of Michigan, he passes from a region dominated by a rich mesophytic broad-leaved forest to one of conifer and xerophytic broad-leaved ascendency; from a region whose low grounds are characterized by a swamp flora to one in whose depressions the bog flora reaches a high state of development. In this connection it is interesting to note that one finds this gradual change epitomized in the Huron valley as he goes from its mouth to its source.

METEOROLOGICAL CONDITIONS.

Under this head we shall consider the general meteorological conditions of the Huron basin, and compare them with the meteorological conditions found about the center of the distribution of bog plants (55, p. 406). In general, this center extends from Lake Winnipeg through the upper Great Lake region down the valley of the St. Lawrence to the Atlantic coast. It is in the coast provinces, however, that the bogs reach their highest development, in the form 
of the "raised bog." Certain temperature phenomena associated with the bog habitat will be discussed in connection with the analysis. of the life conditions obtaining in bogs.

Rainfall.--In the following table is given the mean monthly and annual precipitation for seven stations located within or near the Huron basin. As their individual variation is but small, it is probable that the average for the stations gives a fair estimate of the rainfall and its distribution. Appended are the corresponding records for the maritime region of eastern Canada:

MEAN PRECIPITATION IN INCHES.

\begin{tabular}{|c|c|c|c|c|c|c|c|c|c|c|c|c|c|c|c|}
\hline Station & $\begin{array}{l}\text { Alt. } \\
\text { feet } \\
\text { a.t. }\end{array}$ & $\mid \begin{array}{c}\text { Rec- } \\
\text { ord } \\
\text { for } \\
\text { Y I S. }\end{array}$ & Jan. & Feb. & Mar. & Apr. & May & June & July & Aug. & Sept. & Oct. & Nov. & Dec. & Ann. \\
\hline $\begin{array}{l}\text { Ann Arbor. } \\
\text { Ypsilanti. . } \\
\text { Jackson... } \\
\text { Annpere... } \\
\text { Ball Mt... } \\
\text { Birm'gham }\end{array}$ & $\begin{array}{l}930 \\
736 \\
927 \\
924 \\
932 \\
860\end{array}$ & $\begin{array}{r}23 \\
18 \\
6 \\
11 \\
13 \\
15 \\
\end{array}$ & $\begin{array}{l}1.99 \\
1.97 \\
2.06 \\
1.98 \\
1.73 \\
1.91 \\
\end{array}$ & $\begin{array}{l}2.19 \\
2.61 \\
2.21 \\
2.19 \\
1.76 \\
2.00\end{array}$ & $\begin{array}{l}2.12 \\
2.48 \\
3.14 \\
2.42 \\
2.07 \\
2.32 \\
\end{array}$ & \begin{tabular}{l|}
2.88 \\
2.24 \\
1.26 \\
2.60 \\
2.12 \\
2.53 \\
\end{tabular} & $\begin{array}{l}3 \cdot 72 \\
3 \cdot 98 \\
3 \cdot 22 \\
3 \cdot 38 \\
3 \cdot 52 \\
3 \cdot 36 \\
\end{array}$ & $\begin{array}{l}3.39 \\
4.02 \\
3.02 \\
2.44 \\
3.13 \\
3.15 \\
\end{array}$ & $\begin{array}{l}2.82 \\
3.09 \\
2.47 \\
2.66 \\
2.47 \\
2.56 \\
\end{array}$ & $\begin{array}{l}2.45 \\
2.24 \\
1.76 \\
2.85 \\
2.59 \\
2.38\end{array}$ & $\begin{array}{l}2.58 \\
2.63 \\
1.74 \\
1.93 \\
2.62 \\
2.33\end{array}$ & $\begin{array}{l}2.82 \\
2.70 \\
3.61 \\
2.04 \\
2.69 \\
2.51 \\
\end{array}$ & $\begin{array}{l}2.77 \\
3.29 \\
2.87 \\
2.64 \\
2.71 \\
3.02 \\
\end{array}$ & $\begin{array}{l}2.35 \\
2.32 \\
1.56 \\
1.77 \\
2.30 \\
1.88\end{array}$ & $\begin{array}{l}32.08 \\
33.60 \\
28.92 \\
26.05 \\
29.72 \\
29.95 \\
\end{array}$ \\
\hline Average. & & & 1.94 & 2.16 & 2.42 & 2.27 & 3.53 & 3.10 & 2.68 & 2.38 & 2.30 & 2.73 & 2.88 & 2.03 & 30.22 \\
\hline $\begin{array}{l}\text { St. John, } \\
\text { N.B.(I8) } \\
\text { Halifax, } \\
\text { N. S.(5I) }\end{array}$ & & $\begin{array}{c}? \\
22\end{array}$ & $\begin{array}{l}5.55 \\
5.63\end{array}$ & $\begin{array}{l}3.93 \\
4.94\end{array}$ & $\begin{array}{l}3.80 \\
5.15\end{array}$ & $\begin{array}{l}2.50 \\
4.00\end{array}$ & $\begin{array}{l}3.66 \\
4.43\end{array}$ & $\begin{array}{r}2.72 \\
3.68\end{array}$ & $\begin{array}{l}3.29 \\
3.43\end{array}$ & $\begin{array}{l}4.64 \\
3.96\end{array}$ & $\begin{array}{l}3.08 \\
3.53\end{array}$ & $\begin{array}{l}4.13 \\
5.21\end{array}$ & $\begin{array}{l}4 \cdot 7 x \\
5.26\end{array}$ & $\begin{array}{c}5.16 \\
5.52\end{array}$ & $\begin{array}{l}47.17 \\
57.74\end{array}$ \\
\hline
\end{tabular}

It will be noticed from the above data that the precipitation is quite evenly distributed throughout the year. It reaches its maximum during the months of May and.June, when the vegetative processes of the bog plants are most active. It approaches its summer minimum during July. and August, when the temperature commonly attains its greatest height. The former implies that the water level in the bogs is kept at or above the surface of the substratum for weeks at a time. The latter involves strong transpiration on the part of the vegetation, when the water supply must be drawn for the most part from the substratum. The average number of rainy days during the past five years is one hundred per annum.

The average snowfall in this region during the five years, 1898 to I 902 , amounts to 38.4 inches $\left(975^{\mathrm{mm}}\right)$. In the case of the bogs this thickness is usually increased by the drifting of snow from the surrounding hills. Observations during the past two winters show that the bogs are covered by ice to a thickness of a foot $\left(3 \mathrm{O}^{\mathrm{cm}}\right)$ or more. 
Consequently, low shrubs, and herbs which pass the winter by means of underground stems, are well protected from low temperatures and sudden temperature changes. The ice further results in lowering the temperature in spring and in retarding the beginning of favorable growth conditions.

The percentage of sunshine is not published by the several stations, but the number of clear and partly cloudy days is stated. The numbers from the various stations show marked differences, due to different standards established by the observers; but perhaps these are largely eliminated in the average. If we take the average number of clear days, add to it one-half the number of partly cloudy days, and divide by the number of days in a year, we obtain a percentage of forty-six. This probably approximates the percentage of sunshine.

In comparison with the rainfall data for Halifax and St. John, it is notable that in the latter localities the mean rainfall, both monthly and annual, is considerably larger. The annual precipitation exceeds that of the Huron valley by fully 20 inches $\left(5^{\circ} \mathrm{cm}\right)$, or about 40 per cent. Finally, the sunshine percentage is slightly lower, being 39 for Halifax and 42 for St. John.

Temperature.-The following table exhibits the monthly and annual means for the several stations already cited:

MEAN TEMPERATURE IN ${ }^{\circ} \mathrm{F}$.

\begin{tabular}{|c|c|c|c|c|c|c|c|c|c|c|c|c|c|}
\hline & Jan. & Feb. & Mar. & April & May & June & July & Aug. & Sept. & Oct. & Nov. & Dec. & Ann. \\
\hline Ann Arbor & 22.2 & $23 . I$ & 30.6 & 45.4 & 53.2 & $67 \cdot 3$ & 72.0 & $69 \cdot 3$ & 62.5 & 49.9 & 36.4 & $27 . x$ & 46.6 \\
\hline $1 \mathrm{pos}$ & 25.9 & 24.2 & $32 \cdot 3$ & 46.7 & 58.1 & $63 \cdot 5$ & 71.1 & 69.7 & 61.8 & 49.9 & 36.7 & 27.6 & $47 \cdot 3$ \\
\hline$\ldots \ldots \ldots$ & 26.1 & 20.3 & 32.7 & 47.5 & $59 \cdot 4$ & $69 \cdot 4$ & 74.8 & 71.8 & 64.8 & 54.7 & 37.7 & $26 \cdot 5$ & 48.8 \\
\hline Ann & $24 \cdot 7$ & 21.7 & $31 \cdot 3$ & 50.2 & $56 \cdot 5$ & 68.4 & 71.8 & 67.6 & 63.0 & 49.8 & $35 \cdot 9$ & 26.7 & 47.4 \\
\hline Ball 1 & 22.6 & 21.4 & 27.6 & $45 \cdot 3$ & 56.0 & 66.9 & 70.0 & $68 . \mathrm{x}$ & 62.2 & 49.5 & 35.9 & 27.1 & $46 . c$ \\
\hline Birmingham.. & $23 . x$ & 22.8 & 30.4 & 46.5 & $57 \cdot 3$ & 69.1 & 72.2 & 68.4 & 61.5 & 49.7 & 36.7 & 27.0 & 47.1 \\
\hline Average.... & $24 . I$ & 22.2 & 30.8 & 46.9 & 56.7 & 67.1 & 71.9 & 69.1 & 62.6 & 50.6 & 36.5 & 27.0 & 47.2 \\
\hline Tohr & 18.6 & 18.7 & 26.3 & 38.6 & 48.8 & 56.3 & 61.0 & 6r. & 55.6 & $44 \cdot 7$ & 36.1 & 23.7 & 40.8 \\
\hline & 22.0 & 22.7 & 28.7 & 38.2 & 48.7 & 57.6 & 64.2 & & 58.2 & 48.0 & 38.2 & 27.0 & 43.2 \\
\hline
\end{tabular}

The table shows that the temperature conditions are comparatively uniform throughout the basin. The maximum average temperatures occur in July and August. But the significance of the data becomes more apparent, in so far as the bog vegetation is concerned, when they are compared with those of St. John and Halifax (fig. 3). It is to be noted that, although the average temperature for June, 
July, and August of the Huron basin is $8.6^{\circ} \mathrm{F}$. $\left(4.8^{\circ} \mathrm{C}\right.$.) higher, its rainfall during the same period is less by 2.6 inches $\left(66^{\mathrm{mm}}\right)$. There can be little doubt as to the effect of such differences upon the growth of the bog species, especially the sphagnum whose moisture supply is more directly dependent upon atmospheric water than upon the

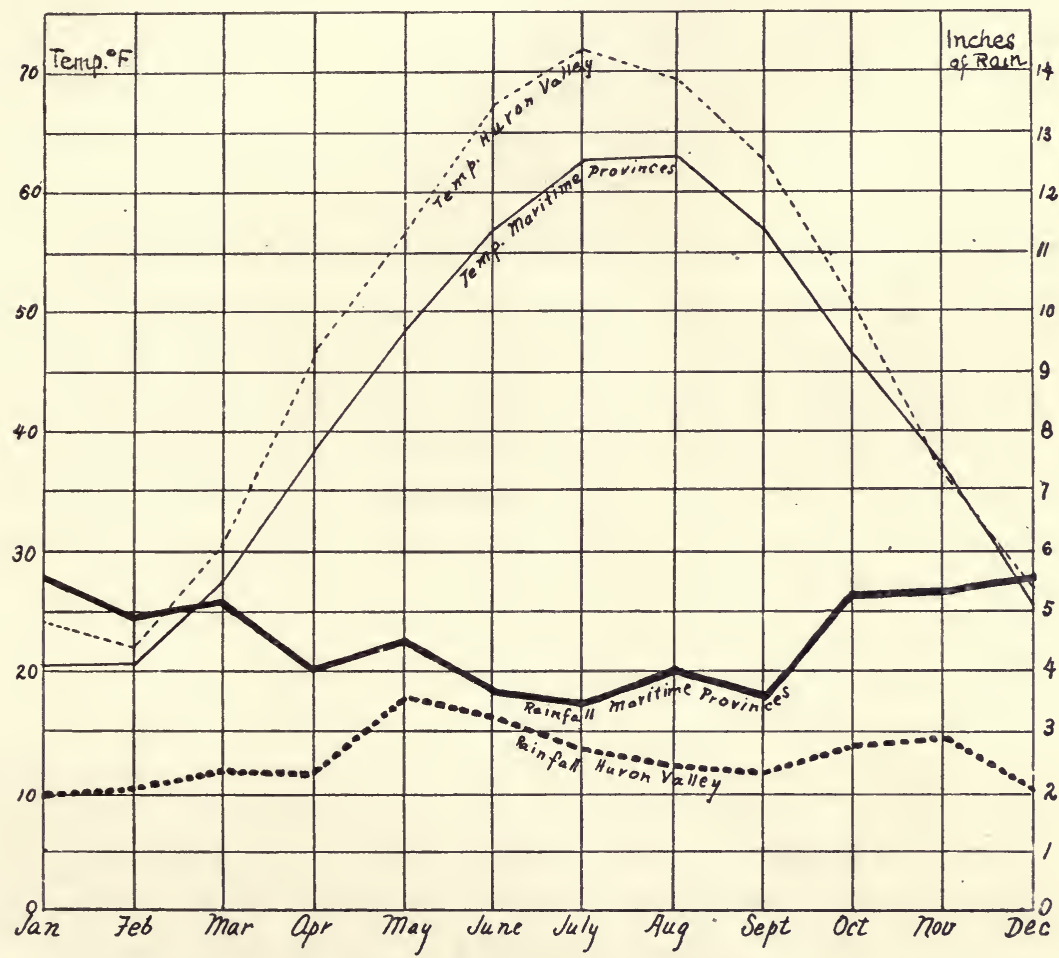

FIG. 3.-Curves of rainfall and temperature conditions in the Huron basin compared with those of the maritime region of Canada.

soil solution. Again, the occurrence of high temperature with decreased precipitation means the production of conditions impossible for the development of the "raised bog," if not unfavorable to the highest development of the "flat bog."

Since bogs attain their maximum development in a region of great rainfall and comparatively low temperatures, it is reasonable to infer that the extremes of summer heat become peculiarly significant in this region. Examination of the weather records shows that 
temperatures of $97-100^{\circ} \mathrm{F}$. $\left(3^{6}-3^{\circ} \mathrm{C}\right.$. $)$ are likely to occur every year, and that temperatures approximating these may be prevalent for several days in succession each season. When these extremes coincide with periods of drought, they must act as important checks on the growth of the bog plants, especially the sphagnum. As we pass from northern Indiana along the moraine into Michigan, the gradual increase of bog development, of the variety of bog species, and of the areas covered by sphagnum is very marked. Although other factors are involved, this increase may be correlated with a decrease in summer temperature extremes.

\section{The bogs: their development and ecological conditions.}

\section{PHYSIOGRAPHIC ORIGIN OF THE LAKE AND BOG BASINS.}

In connection with the special consideration of the bog flora, it is of interest to note the origin of the depressions in which this flora has developed and flourished. Indeed, in the morainic belt of the Huron basin it would seem that among the agencies which have produced important topographic changes since glacial times, the bog plants stand near the head of the list. Stream erosion and deposition have been slight, while lake basins have been filled and the level of depressions generally raised by the deposition of plant débris.

As no attempt has as yet been made at the mapping of peat deposits and muck soils, no reliable estimate of the total amount of aggradation accomplished by plant agencies can be made. Yet the frequency with which in field work one encounters peat soils, in various stages of making or decay, suggests that in the aggregate such deposition has been most effective in this region. The northwest quarter of the Ann Arbor topographic map, which embraces an area of about 215 square miles (55,700 hectares), located in the morainic portion of this basin, indicates approximately 43 square miles (I I, 500 hectares) - 20 per cent. - as swamp land. It is probable that at an early time this area was very much larger, but with the settlement of the land many extensive areas have been drained and only the dark humous soil remains to suggest its past history.

The most frequent source of lake and bog basins is here found in connection with the deposits made by glacial drainage. Among the vicissitudes attending the retreat of a glacier are the occasional 
detachment of blocks and masses of ice through differential melting (I9). If these detached masses happened to be in the line of the overloaded glacial drainage, they became covered to a greater or less extent by sand and gravel. Owing to the poor conduction of heat by such deposits, they melted with extreme slowness. Where this latter process was prolonged until the drainage line had been abandoned or the stream had ceased depositing, subsequent melting brought about a settling of the deposits and the production of basins. Sister, Kavanaugh, and Crooked Lakes are examples of this type.

In the case of the chain of lakes which form a part of the Huron River in northwestern Washtenaw County, and such lakes as Portage, Tamarack, Ore, and Bass; according to LeverEert, there was an additional settling of the fluvio-glacial deposit itself. This latter process has been of the greatest importance in the development of extensive bog areas. In the Portage Lake region this settling has amounted to as much as 40 feet $\left(\mathrm{I}^{2}{ }^{\mathrm{m}}\right)$ in certain places, and has resulted in reducing many hundreds of acres of land to the ground water level.

Throughout the belt of till plains occur shallow marshes, sometimes drained, but usually by a sluggish meandering stream, itself impeded by the growth of swamp plants. These basins are the natural expression of the unequal deposition of glacial material. Till plains result from a comparatively rapid retreat of the ice; hence the depressions are usually shallow, and have been mostly filled with peat to the level of the present drainage. The several small lakes lying to the west of Dexter are examples of basins not yet obliterated.

Where the retreat of the glacier is slow and deposits are made to a great thickness about the edge of the ice, kame or "knob and kettle" topography results. The basins of such areas are characterized usually by high margins and comparatively steep slopes. West, Silver, North, Island, and South Lakes may be cited as examples.

As we know from remains discovered in peat deposits, among the animals inhabiting this region in early postglacial times were the mammoth, mastodon, bison, peccary (Platygonus compressus LeConte) (57), elk, and "big beaver" (Castoroides ohioensis Foster). The last named is not a beaver (34, p. 256), but is more nearly related to the Coypu rat of South America. The common beaver 
(Castor canadensis Kuhl) has been an important factor in the creation of bog areas (37), and in the extension of areas already existing, by the building of dams. The beaver was found in this section when it was first settled, but the last known specimen was killed sixty-nine years ago. The occurrence of peat deposits several feet in thickness and covering quite large areas, bordering streams, whose channels lie deeply sunken in the deposits, seems to find its best explanation in this manner. But little field work has been done on the relation of beavers to the peat deposits, and examples are still too hypothetical to cite in this connection.

\section{BOG AND LAKE VEGETATION.}

Of the plants which might come into a new land area containing basins, such as was laid bare on the retreat of the glaciers, none is better adapted to rapid migration than the group of aquatic plants. Whether we have in mind the smaller submerged varicties or the partially submerged littoral species, their wide geographic distribution and uniform associations bespeak their evident solution of the problems of dispersal. The fact that deposits of peat and marl have been found in northern Indiana and lower Michigan to a thickness of 40 feet $\left(12{ }^{\mathrm{m}}\right)$ would indicate that in these particular basins the vegetation must have obtained an early foothold.

Concerning the deposition of marl, it is of interest to us only in so far as it becomes an agent of aggradation in the basins. In the reports $(\mathbf{5}, \mathbf{4 2}, \mathbf{2}$ I) on the marl deposits of Indiana and Michigan, many examples are cited where the marl forms the underlying substratum of peat deposits. That its deposition to a large extent is due to plant life has been shown by Davis $(9, \mathbf{r o})$. The plants most concerned with this process are the Characeae and Cyanophyceae (Schizothrix, Zonotrichia). They are probably aided by certain mollusks, and perhaps also by chemical precipitation. As for the Characeae and Cyanophyceae, they have a wide range of habitat in different lakes, and may occur in deep or shallow water and on various rock substrata. Where they come into competition with shore species, the rank growth of the latter usually precludes their existence in sufficient amount to be of importance in marl formation. Where wave action is strong, the chara is confined to deeper water, 
but the blue-green algae may be present up to the water's edge, in such situations frequently forming marl pebbles. The lower limit of existence is largely determined by the transparency of the water, and may lie between 20 and 30 feet $\left(6-9^{\mathrm{m}}\right)$. Of the littoral plant associations there are commonly two quite distinct divisions, the outer made up largely of submerged or floating pondweeds and waterlilies, the inner of half-submerged rushes and sedges. Both are concerned in the process of peat formation. Under such conditions there naturally develop, in regions of calcareous underground waters, an outer zone of chara dominance and marl deposition, and an inner zone of pondweed-sedge dominance and peat deposition. Variations in the slope of the bottom, in the amount of wave action, in the presence of shore currents, and in the color of the water, determine whether one or both of these processes shall go on, and to what extent these activities are kept distinct or grade into one another.

In the case of the peat, however, the process is not dependent upon water species alone. They act merely as forerunners of a denser and more luxuriant vegetation which frequently is of greater quantitative importance. Briefly, we may note here that in the case of the bogs, unlike that of the swamps, the plants which develop on the margin, especially Carex filiformis and forms of Eriophorum, are able to secure all of their food materials from the water and air and build their own substratum. This tangle of roots and rhizomes usually attains a thickness of several inches, and on account of its low specific gravity floats on the surface of the water. Upon this foundation the sphagnum and bog shrubs advance, adding their quota to the débris. Later, these are followed by such tree forms as the tamarack. Coincident with this increased weight and augmented rate of deposition, comes the progressive submergence of the floating substratum, and its gradual disintegration and humification. The accompanying fig. 4 will serve to illustrate this process.

Within the last two years much has been promised toward the utilization of the peat deposits in this region for fuel purposes. Companies have been organized, and the machinery necessary for the drying and consolidating of the peat has been much improved. At Capac and Chelsea, factories have been erected, and attempts are being made to place the industry on an economic basis. If these 
ventures prove successful, we may hope for an interesting body of scientific information to come from the study of bog sections. The work of Anderson, Lagerheim, Sernander, Weber, and others in Sweden and Germany, gives indication of the data concerning postglacial migrations of plants and animals, and climatic changes, which will be obtainable when our bog deposits become of economic importance.
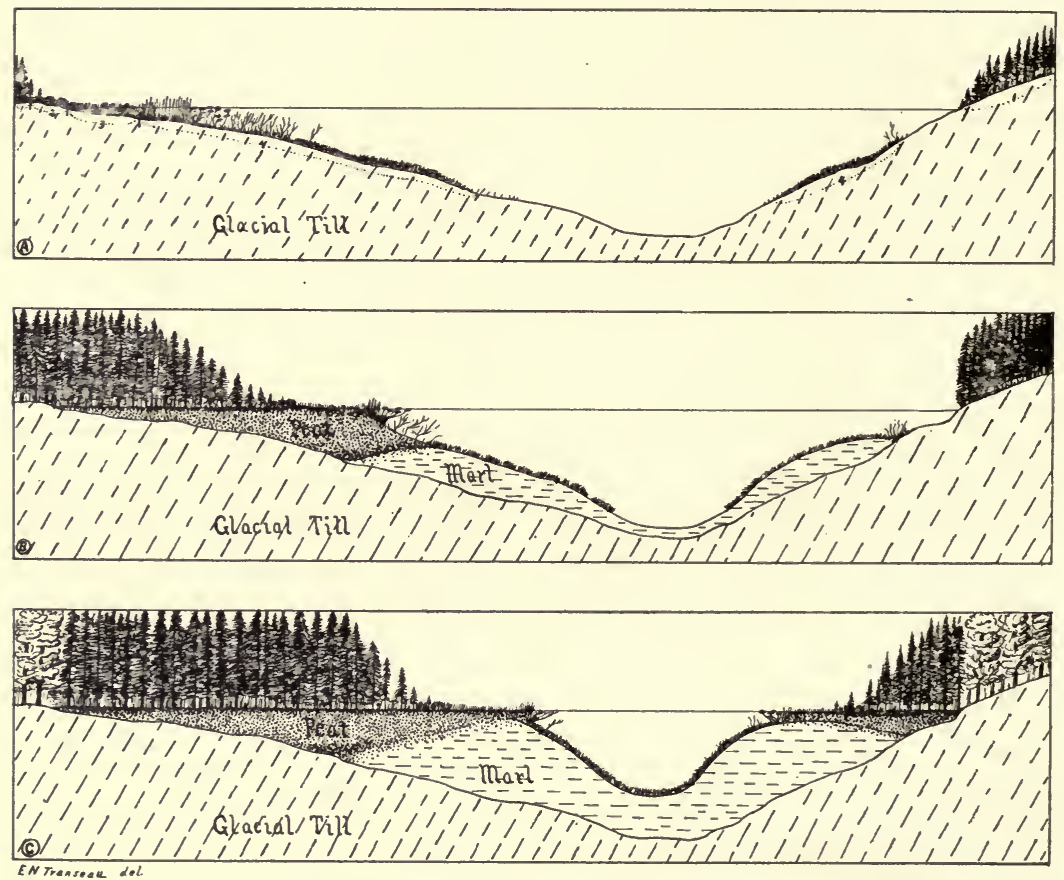

FIG. 4.-Diagrams illustrating three stages in the development of peat and mar deposits in lake basins. In drawing the figures it has been assumed that the rates of marl and peat deposition are approximately equal. The peat accumulates most rapidly on the western side of the basin. On the east side a common effect of wave action is illustrated. The process of peat formation is hindered, while that of marl deposition goes on until the aggradation of the bottom reduces the force of the waves sufficiently to allow the bog plants a foothold. A represents conditions in early postglacial times when these basins acquired their first flora. The several plant societies represented are (I) conifer (2) bog shrub, (3) bog sedge, (4) aquatic, the outermost division of which is the chara association. In $B$ the conditions for the growth of plants belonging to the northeastern conifer forest formation have reached their optimum. $C$ represents present conditions in southern Michigan. The plants belonging to the southeastern broad-leaved forest formation, being climatically favored, occupy the areas of mineral soils, while the conifers are almost restricted to bog areas. 
THE GEOGRAPHIC DISTRIBUTION OF PEAT DEPOSITS.

In North America the distribution of recent peat deposits may be conveniently summarized under two heads, genetically unrelated: (I) those of glaciated regions; (2) those of the coastal plain.

The peat of the glaciated area constitutes the great bulk of these American deposits. The southern boundary of this region is marked by a line passing westward from central New Jersey through northern Pennsylvania and Ohio, central Indiana and Illinois, thence northward through southern Wisconsin, northwestward to the Minnesota valley and the Red River of the North in Manitoba, westward through northern Assiniboia and southern Alberta to the Rockies. Here the boundary is deflected southward into Montana, but in crossing toward the coast it is again carried northward into British Columbia, and finally southward among the Cascades of Washington to the Pacific Ocean.

Along this southern border the peat deposits are exceedingly scattered and make up a small fraction of the total land surface. They have accumulated under water in depressions among the recessional moraines. As we go northward, the relative proportion of peat bogs and peat deposits regularly increases, and there is a notable tendency toward the accumulation of pure humus in situations other than depressions containing water. When the tundra or "barren ground" is reached, the accumulation of humus is almost universal. The contrast with our own region is well brought out in RusselL's account of the tundra (43, p. I29). The vegetation

grows rapidly during the long, hot, summer days, dies below and partially decays, but becomes frozen and has its complete destruction arrested, while the dense mat' of roots and stems continues to thrive. In this way an accumulation of partially decayed vegetable matter is formed, which increases in thickness from year to year by additions to its surface. The process is similar to that by which peat bogs are formed in temperate latitudes, except that the partially decomposed vegetation becomes solidly frozen. It is in reality an example of cold storage on a grand scale.

Under existing climatic conditions there does not seem to be any limit to the depth such deposits may attain. The amount of carbonaceous material already accumulated in the tundras of America and Asia must equal that of the most extensive coal field known.

South of the boundary above described, peat deposits of consider- 
able extent are occasionally met with. In the region of the great plains they are sometimes found beneath a surface covering of sand and wind-blown deposits. TodD (54, p. I2I) has mentioned the occurrence of such peat deposits in eastern South Dakota. BARBour also reports such deposits from central and eastern Nebraska (2). On the basis of their field relations and certain fossils which they contain, they are believed to be of Glacial and early Pleistocene age. If the plant materials of these deposits could be carefully worked over with reference to their successive floras, we might hope for some new light on glacial climate, since a part of the deposits are beyond the margin of the Wisconsin ice sheet. But even their location and existence give evidence of climatic change, and plant and animal migration. Although now widely separated from the region of active bog formation, they are historically connected with this division.

Among the mountains of both the eastern and western United States, bogs and swamps are to be found in association with mountain lakes. More frequently than otherwise these depressions are connected with former local glaciation, perhaps the most frequent situations being those afforded by the damming back of water by terminal and lateral moraines. Basins for peat accumulation are also found in solid rock made by glacial erosion. The conditions here are quite similar to those of the north, the altitude bringing about the same general effect as the latitude. The analogy is still further shown on mountains in moist regions where alpine meadows are strongly developed. Not only are the plants related to those of the tundra, but the deposition of peat or humus is again irrespective of basins.

In many places east of the great plains there is another type of situation not directly connected with glaciation, but in which vegetable débris may accumulate to considerable thickness, viz., about the débouchure of cold springs. Toward the north these springs may bring about humus accumulation on slopes, but further south peat is usually associated with pools and small lakes.

The second group of situations in which peat accumulation takes place on a grand scale, are those associated with coastal plain phenomena, such as the rising and sinking of the land, the irregular deposition of alluvial materials in deltas, and the extension of the 
land through reef building. These swamps have been described by Shaler, Kearney, Julien, and others $(46,26,24,7)$. They reach their greatest development in eastern Virginia, North Carolina, Florida, and the Mississippi floodplain. They may contain either salt or fresh water, and their vegetation is noted for its density and luxuriance.

The geographical distribution of peat deposits is of interest in this connection because it points to certain factors which contribute to the preservation of humus materials. Certainly in arctic latitudes the most significant factor is the low temperature, for humus accumulates to great thickness even with a scant vegetation. In the northern states and southern provinces of Canada, peat is associated with basins containing stagnant water or cold springs. The annual increment from the vegetation is greatly increased over that of the tundra. Mild temperatures and stagnant waters combine to preserve the plant débris. When we come to the coastal plain swamps of the southern states, this process takes place only where a luxuriant vegetation is combined with areas of stagnant water of considerable depth.

To put it sharply, we may say that, in spite of the scant vegetation, the cold of the tundra results in peat accumulation. In temperate latitudes, mild temperatures and stagnant water combine to prevent the complete disintegration of a vigorous vegetation. In the south, in spite of the high temperature, the luxuriance of the vegetation and stagnant water unite to make peat formation possible.

\section{THE PROCESSES INVOLVED IN PEAT FORMATION.}

When for any reason the living protoplasm in a plant or any of its organs is brought to the condition of death rigor, the continuance of this state for a prolonged period inaugurates certain chemical and physical processes which result in the breaking down of the exceedingly complex structures and compounds making up the living plasma. Among the first outward signs of such disorganization is the loss of water. The cells of soft tissues lose their normal form, and in any case the tissue becomes more or less filled with gases. The protoplasts as such disappear, and in their place granular carbohydrate and proteid bodies are to be found. 
Aside from the mineral substances composing the ash of such bodies, the organic compounds are made up for the most part of carbon, hydrogen, and oxygen. In the case of the proteids, there are added to these nitrogen, sulfur, and phosphorus. As to the exact nature of the compounds existing in the dead material, aside from the carbohydrates, very little is known. The same statement holds as to the nature of the decomposition which goes on without the intervention of saprophytic organisms. But it seems probable that oxidation does occur. This action, then, is the beginning of the more comprehensive process known as peat formation.

When plants or their organs die, under ordinary circumstances they are at once attacked by fungi and bacteria. The progress of dissolution is then greatly hastened, and the final disintegration is more complete. According to the operation of certain external factors, the destruction may involve two very different groups of organisms and result in bodies of very different chemical and physical properties. These two processes are known as eremacausis and putrefaction (6r, 39).

Where access to oxygen is accompanied by favorable temperature and moisture conditions, the first of these processes, eremacausis, takes place. The formation of ordinary soil humus may be cited as an example. That oxygen plays the important rôle has been demonstrated both by experiment, and by the analysis of the gaseous and solid products. It has been shown, for example, that soils in which eremacausis is in progress contain $\mathrm{CO}_{2}$ and $\mathrm{O}$ in inverse proportion to one another. Under constant volume, as the one increases the other decreases. It has been also shown by experiment that the process is wholly dependent upon the activities of certain lower plants. Among these members of the genera Mucor, Aspergillus, Penicillium, Saccharomyces, Micrococcus, Bacterium, Spirillum, Crenothrix, and Beggiatoa are most important.

The carbohydrates are by this means broken down to $\mathrm{CO}_{2}$ and $\mathrm{H}_{2} \mathrm{O}$. The albuminoids and amides constitute the principal forms of the nitrogenous materials. Under the influence of these organisms, especially their katabolic processes, the oxygen unites with the carbon to form $\mathrm{CO}_{2}$, the $\mathrm{S}$ is oxidized to $\mathrm{H}_{2} \mathrm{SO}_{4}$, the $\mathrm{P}$ to $\mathrm{H}_{3} \mathrm{PO}_{4}$, and the $\mathrm{H}$ to $\mathrm{H}_{2} \mathrm{O}$. The first form in which the nitrogen reappears is that 
of ammonia. This is at once attacked by the nitrifying bacteria, and changed successively to the form of a nitrite and a nitrate. The two latter changes again involve the addition of oxygen.

If we consider only the temperatures occurring in nature, we may say that these activities increase regularly with the temperature. As to water conditions, it has been shown that in air-dry soil eremacausis is practically wanting, and that when the soil is filled with water it is reduced to a minimum. Between these two extremes lies an optimum at which there is sufficient moisture for the life of the organisms, and yet not enough to interfere with the diffusion of oxygen. An acid condition impedes, and a slight alkalinity favors, the production of both the carbon and the nitrogen compounds.

Eremacausis is then essentially a process. of oxidation, brought about by lower organisms, whose activities are favored by a high temperature, a slightly alkaline medium, and free access to the air. Its products are simple compounds which may furnish food materials for the higher plants living on the substratum in which they are formed.

By putrefaction is meant that process of disintegration which occurs when organic matter decays in the absence of oxygen. Here again organisms are involved, but they belong for the most part to the anaerobes, and are wholly forms of bacteria. The process is essentially one of reduction.

Carbon dioxid is again the principal gaseous product, but its relative amount is greatly reduced. Along with it $\mathrm{CH}_{4}, \mathrm{H}, \mathrm{H}_{2} \mathrm{~S}$, $\mathrm{H}_{3} \mathrm{P}, \mathrm{N}_{2} \mathrm{O}$, and $\mathrm{N}$ are produced in small quantities. In the manufacture of the carbon dioxid the oxygen is not only derived from the organic matter, but also from nitrous oxid, nitrites and nitrates which may be present. In the decomposition of cellulose, carbon dioxid and methane result from the hydrolysis of the cellulose molecule. Albumins at first break up into amido-acids, nitrogenous compounds of the aromatic series, and other little-known bodies. If the decomposition continues, the amido-acids in turn form ammonia and compounds of the fatty-acid series. The latter substances may still further disintegrate to carbon dioxid, hydrogen, and methane. Depending upon the stage in the progress of decomposition, we may find complex organic compounds, organic acids, and their salts, or comparatively simple substances. 
As to the influence of external factors, high temperatures increase the rate of disintegration, while the presence of acids prevents its continuance, due to the killing of the bacteria involved. It is to be noted that the products of putrefaction, both intermediate and final, can be of little use in furnishing food materials for the higher plants.

With these two processes in mind, we may now consider the matter of peat formation as it occurs in this region. We have already seen how the substratum is being extended at the edge and renewed at the surface by the plants forming the outer zone of the bog vegetation. It consists of sedges, especially forms of Carex and Eriophorum. Each year these plants send up stems and leaves from the matted rhizomes. At the approach of winter these are killed, and the snow later on aids in bringing them down to the water level. In the spring the water covers almost the whole of this zone to the depth of several inches. With the gradual lowering of the water level and the coming of warmer temperatures, the conditions for eremacausis are made favorable. If the water is approximately neutral in its chemical reaction, the fungi and bacteria begin the work of disintegration, which if continued would result in the complete destruction of the vegetable débris. However, on account of the great demand for oxygen, the process can be carried on only near the surface of the water. Even at a depth of a few centimeters the rate of oxygen diffusion -is so small, as compared with the demand for it, that practically all aerobic bacterial action is prevented. All of the surface waters which I have examined have been found to be teeming with bacteria.

Close upon the extension of the bog-sedge zone comes the sphagnum-heath zone. Here the surface is characterized by hollows and elevations, the latter frequently due to the upward growth of the sphagnum beneath the shade of the heath plants, but in some cases due to the building of mounds by ants. In the hollows the water stands above the substratum throughout a large part of the year and even during dry periods lies just at the surface. Unlike the sedges, the principal plants of this zone are evergreen. The sphagnum forms a continuous mat of living plants several centimeters in thickness, through which all of the oxygen must diffuse before it can be available for the eremacausis of the dead plantmaterial beneath. The cassandra, cranberry, and andromeda which compose the bulk of the shrubby vegetation add to the débris largely 
by their leaves and underground stems. The former fall to the substratum as they die, but not at the close of each vegetative period. Consequently they are soon lost among the sphagnum, and there is no distinct annual layer added.

But beneath this layer of possible aerobic activity, the material would seem to be subject to putrefactive agencies. And there can be no doubt that such destructive processes are carried on in those situations in which the acidity of the soil solution does not preclude the existence of the anaerobic bacteria.

Among the taller shrubs and trees, such as Vaccinium corymbosum, Aronia nigra, and Larix laricina, the defoliation takes place each autumn. As these plants are of relatively large size, the bulk of the material forms a noteworthy annual addition to the substratum. When to this is added the twigs and small branches which fall each season, we can understand the fact that the substratum is almost entirely free of surface water. Usually the ground-water level lies $5^{-10^{\mathrm{cm}}}$ below. But the substratum has a high water-capacity and is kept constantly moist. Where the sphagnum covering is wanting for one reason or another, the dark color of the surface peat shows how much more complete is its disintegration as compared with that of the other zones. This condition is made possible by its position relative to the ground water. On the other hand, as will be shown later, the temperature conditions are more favorable in the zones of herbaceous and shrubby vegetation.

Most of the basins in which peat formation is going on actively, are subject to considerable variation in water level, both seasonal and annual. During the last two years the rainfall has been considerably above the normal in lower Michigan, and many of these bog areas were flooded. At West Lake, for example, a large part of the tamarack area was covered with water to a height of several inches above the level of the roots. Most of the basins are also subject to higher water level in the spring and during prolonged rainy periods. Accompanying such changes there are great differences in the rate and manner of decay. High water, in so far as it excludes oxygen, favors putrefaction; if it comes as a result of heavy rains, it decreases the acidity of the soil solution, increases its oxygen content, and at least for a short time favors the growth of the saprophytes causing eremacausis. Low water level exposes a much greater bulk of the 
substratum to disintegration, and favors the carrying away of the products of decomposition; in general, it favors eremacausis. In the samples of water which I have examined at various times from the same depressions, there have been marked variations within short periods of time in the color of the water and in the presence of such animals as Daphnia and Cyclops. No attempt has been made to count or even separate the bacteria present, but it is probable that they too vary with the color of the water and the animal life.

When the bog land has been cleared and ditched, the marked increase in the rate of decay is apparent. Eremacausis becomes exceedingly active, and in the course of a few years the substratum is reduced to a brownish-black, pulp-like mass. If continued, this goes to form "muck," a substance which when dry is powdery and somewhat resembles soot. During these processes of decay there occurs a succession among the organisms present. The accumulation of disintegration products makes the medium unfavorable for the continued existence of the organism involved in their production. At the same time it may furnish optimum conditions for the development of other forms. An acid medium favors the growth of the Phycomycetes, while alkalinity favors the bacteria. In such regions as this, where the underground waters are alkaline, the latter fact, together with fluctuations in the ground-water level, may have an important bearing upon the presence of more thoroughly decayed peat and of a distinct depression about the margins of many of the bogs.

If to the factors of relative scarcity of oxygen and the acidity of the soil solution is added the occurrence of temperatures considerably lower than those of the surrounding uplands, it is not difficult to understand why a large part of each year's vegetative products should escape complete destruction. In our estimate of the bog substratum as a habitat for higher plants, the strong competition with the microscopic plants to which the former are subject in the acquisition of oxygen for their underground parts, must be emphasized.

\section{THE PHYSICAL AND CHEMICAL PROPERTIES OF PEAT.}

The peat formed through the agency of the bog sedges and their attendant plants has a fibrous and matted appearance. The structures of the various dead stems, roots, and leaves have suffered but slight 
alteration. They were originally strongly cuticularized, and this has aided in their preservation. The color is commonly a pale yellowishbrown. During life these plant materials become strongly matted and interwoven, and this structure frequently persists. It is this structure that gives to the Carex-Eriophorum zone in many lakes its strength to support heavy bodies. A man's weight will carry the substratum a foot beneath the surface of the water, but it seldom breaks under the strain. In the case of lakes where this zone is unusually developed, it may cover a large part of the lake surface and be of great importance in the filling in of peat. In such cases the deposition takes place largely by the gradual falling of material from the under side of the floating substratum. On account of the slight weight of the material, it does not descend and produce a compact deposit on the bottom, but forms a sort of thick liquid peat.

The sphagnum-shrub zone, where well developed, usually shows a brown peat beneath it. It is composed largely of sphagnum and the semi-decayed twigs, rhizomes, and leaves of the other. plants. It is distinctly fibrous, but of a type different from that of the sedge zone; the fibers are short, and the material is not nearly so tenacious.

Under the tamaracks a large part of the annual peat increment is made up of the tamarack needles, though mosses (Hypnum, Sphagnum, and Polytrichum) usually are of importance in this connection. The color is reddish-brown and darker than that of the shrubby zone. The fibrous structure is still less apparent, though present.

When these bogs have been burned over and partially drained, there frequently comes in a dense ground covering of moss (Polytrichum). In such cases the peat continues to accumulate, largely through the agency of this plant. In such situations the peat is a reddish-brown, and the plant structures have practically disappeared through decay. Below the upper layer, the peat when moist has the sticky, clayey properties of well-decomposed peat.

One other well-marked stage is shown in the areas of muck land now under cultivation to onions and celery. Under the influence of drainage and tillage, the disintegration is nearly complete. All plant structures have disappeared, the humous acids have been largely neutralized or washed out, and there is left only a fine, powdery, brownish-black "muck." 
The following table shows some other physical properties of these several varieties of peat.

\begin{tabular}{|c|c|c|c|c|c|c|}
\hline & $\begin{array}{l}\text { Eriopho- } \\
\text { rum Zone } \\
\text { Peat }\end{array}$ & $\begin{array}{c}\text { Fresh } \\
\text { Sphagnum }\end{array}$ & $\begin{array}{l}\text { Cassandra- } \\
\text { Sphagnum } \\
\text { Zone Peat }\end{array}$ & $\begin{array}{l}\text { Tamarack } \\
\text { Zone Peat }\end{array}$ & $\begin{array}{c}\text { Chelsea } \\
\text { Bog Peat }\end{array}$ & $\begin{array}{c}\text { Onion } \\
\text { Marsh Muck }\end{array}$ \\
\hline $\begin{array}{c}\mathrm{H}_{2} \mathrm{O} \text {-capacity } \% \\
\text { by volume........ } \\
\mathrm{H}_{2} \mathrm{O} \text {-capacity } \% \\
\text { by weight......... } \\
\text { Air dry } \mathrm{H}_{2} \mathrm{O} \text {-con- } \\
\text { tent } \% \ldots \ldots \ldots \ldots\end{array}$ & $\begin{array}{r}87.0 \\
892.0 \\
8.5\end{array}$ & $\begin{array}{r}\text { I550.0 } \\
\text { I0. } 6\end{array}$ & $\begin{array}{l}960.0 \\
10.0\end{array}$ & $\begin{array}{l}530.0 \\
10.0\end{array}$ & $\begin{array}{r}477.0 \\
10.0\end{array}$ & $\begin{array}{r}75.0 \\
283.0 \\
\text { I0.० }\end{array}$ \\
\hline
\end{tabular}

* Low volume percentage due to air present in tissues.

These measurements were made by placing the peat samples in a zinc cylinder of $600^{c c}$ capacity. The bottom of the cylinder was closed with a wire gauze cap. The moist peat was tamped into the cylinders with as nearly uniform a stroke as possible. The cylinders were then set in a dish of water for eighteen hours, after which the cylinder was removed and allowed to drip. When all dripping had ceased, the cylinder was weighed. The peat was then removed and allowed to dry at room temperature, and again weighed. Finally it was dried at $110^{\circ} \mathrm{C}$., and the absolute weight determined. As usual in such measurements, considerable irregularity was shown by the different samples, owing to the difficulty of removing the air, and of packing to the same degree. However, the figures bring out clearly the fact that sphagnum more than any other plant influences the water-capacity of a peat containing it. The eriophorum peat has a lower capacity, owing to its coarse fibrous structure. Of the series examined, the highest water-capacity was found in the cassandra zone. The effect of further decay and destruction of the plant tissue is shown by the reduction in water-capacity of the last three members of the series. The percentages are of interest in connection with the utilization of such lands for agricultural purposes, in showing the difficulty of proper drainage. It is the experience of the men who ditch these bogs that until the peat has reached the condition termed "muck" the ditches act only with extreme slowness.

Chemically, peat or humus is made up of varying quantities of several substances of a rather indefinite character, which are commonly classified among the dehydration products of the carbo- 
hydrates. These bodies not only occur in nature, but may be artificially produced by the action of strong acids on starch, sugar, and cellulose. The relation of nitrogen to these bodies is still unknown. Principally on the basis of color and solubility in alkalies and acids, there are several substances distinguished. Ulmin and ulmic acid are brown, and are early products of decomposition. Humin and humic acid are black, and occur more abundantly where eremacausis has been active for a long time. Crenic and apocrenic acids appear to be further oxidation products; the former is colorless, and the latter varies from yellow to brown. MAYER believes these bodies to be organic nitrogen compounds.(36), and on this basis STOCKBRIDGE (50, p. I35) explains the insolubility of peat soils and the presence of the unavailable nitrogen in peat. Beside these substances xylic, saccharic, and glucinic acids have been recognized. Although great advances have been made in soil chemics, it seems strange that the only suggestion of formulæ for these substances was made by MULDER in $\mathrm{I} 86 \mathrm{I}(38)$.

Humic acid forms water-soluble compounds with the alkalies, and to these are due largely the brown colors of the bog waters. The color may be produced by the presence of free humic acid. With the alkaline earths humic acid forms insoluble or difficultly soluble compounds. Hence there is slight chance of lime and magnesia penetrating from the surrounding soil into the peat deposits.

During the changes which the plant material undergoes in the process of peat-making there are alterations in the relative amounts of volatile hydrocarbons, fixed carbon, and ash-using these terms as in ordinary coal analyses.

\begin{tabular}{|c|c|c|c|c|c|c|}
\hline & $\begin{array}{l}\text { Eriopho- } \\
\text { rum Stems } \\
\text { and Leaves }\end{array}$ & Sphagnum & $\begin{array}{l}\text { Eriopho- } \\
\text { rum Zone } \\
\text { Peat }\end{array}$ & $\begin{array}{l}\text { Cassandra } \\
\text { Zone Peat }\end{array}$ & $\begin{array}{l}\text { Tamarack } \\
\text { Zone Peat }\end{array}$ & $\begin{array}{l}\text { Onion } \\
\text { Marsh } \\
\text { Muck }\end{array}$ \\
\hline Volatile combustible & 68.2 & 67.0 & 62.0 & 54.0 & 53.0 & $45 \cdot 7$ \\
\hline Fixed carbon....... & 21.0 & 17.9 & $2 \mathrm{I} .8$ & 22.9 & $23 \cdot 4$ & 21.8 \\
\hline 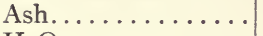 & 3.8 & $4 \cdot 5$ & $7 \cdot 4$ & I3. 8 & I3.6 & $22 \cdot 5$ \\
\hline $\mathrm{H}_{2} \mathrm{O} \ldots \ldots \ldots \ldots$ & 7.0 & 10. 6 & 8.8 & $9 \cdot 3$ & I0.0 & 10.0 \\
\hline
\end{tabular}

The proportion of volatile combustible matter decreases regularly as the humification proceeds. The ash regularly increases, while the air-dry water content shows but slight modification. 


\section{THE BOGS AND BOG FLORA OF THE HURON RIVER VALLEY.}

EDgar NELSON TRANSEAU.

(WITH SIXTEEN FIGURES)

[Continued from p. 375.]

THE BOG AS A HABITAT FOR PLANTS.

WHEN we consider the bog as a habitat for plants, there is at once brought to mind the marked contrast between its characteristics and those of the other plant habitats of its vicinity. In both its atmospheric and edaphic conditions it is unique. The various factors entering into the plant environment will be discussed as physical, chemical, and biotic agents.

A. Physical factors.- - I. Wind.-Because of the fact that so large a number of our bogs lie in depressions surrounded by hills, the influence of the wind is somewhat lessened. It is only in the case of the larger basins that its effects become marked. It has been noted by several students of bogs $(4 \mathrm{I}, 5, \mathrm{p} .37 ; 59,47)$ that in the region of prevailing westerly winds the greatest development of bog areas and peat deposits occurs on the western sides of lake basins. Where the deposition has taken place in a large lake basin, which is now only partially filled, we commonly find open water occurring toward the eastern side. The peat deposits at Portage, Parks, and West Lakes in the vicinity of Ann Arbor are massed on the western shores, while the eastern margins exhibit an ordinary lake beach. At the bogs north of Delhi, although nine-tenths of the original basin has been filled, the two small lakes are near the eastern margin. The facts noted in this region all favor the idea of the bog plants being unable to gain a foothold on the eastern side in the presence of wave action. The shoreward thrust of the ice is of importance at times in this connection.

Farther north in Michigan the wind frequently shows its extreme effect in these bog areas in the presence of "windfalls." Owing to the character of the substratum, such areas are more readily affected 
than the forests of mineral soils. These phenomena have not been observed in any of the bogs in this vicinity.

The same statement holds for the presence of loose floating bogs which are driven about on lakes by winds (35).

2. Temperature.-In its temperature relations both the topography and the character of the substratum combine to influence the bog habitat. It has long been noted by agricultural writers that reclaimed bog areas are particularly subject to late frosts in the spring. One of the causes of this peculiarity lies in the fact that on clear and quict nights the cooled air overlying elevations drains into the depressions (II). Some recent observations made by SeEley (45) near Chicago show how effective such atmospheric drainage may be even in districts whose range of elevations amounts to but $\mathrm{I}_{5}$ feet $\left(4 \cdot 5^{\mathrm{m}}\right)$. $\mathrm{He}$ found that the hilltop averaged, on the night of the observations, $2.5^{\circ} \mathrm{F}$. ( $1.4^{\circ} \mathrm{C}$.) higher than that of the depression while a thermometer placed 30 feet $\left(9^{\mathrm{m}}\right)$ above the hilltop averaged $8.8^{\circ} \mathrm{F}$. $\left(5^{\circ} \mathrm{C}\right.$.) above that of the "swale." On comparing the temperatures of atmospherically undrained and drained depressions with that of the hilltop, he found that the hilltop temperature was $36.3^{\circ} \mathrm{F}$. when that of the drained depression was $36^{\circ} \mathrm{F}$. and that of undrained $3 \mathrm{I} .8^{\circ} \mathrm{F}$. Here is a particular instance in which frost occurred in the undrained depression, but not in the other situations. On quiet nights low grounds in general are subject to lower temperatures than the adjoining highlands, and it is probable that these effects are more pronounced in the case of undrained depressions.

A second factor in the production of low temperatures in bogs is found in the nature of the substratum. In the spring the ice which has formed beneath the cassandra and tamarack areas melts with extreme slowness, when once the surface of the soil has been reached. This is explained by the low conductivity of the loose, partially decayed, vegetable covering, and by the shading of the plants above. For example, at First Sister Lake, in $\mathrm{I}_{904}$, the ice had disappeared from the water surface on April ıo. On April I7, with an air temperature of $10^{\circ} \mathrm{C}$., the temperature of the substratum in the bog sedge zone averaged $10^{\circ} \mathrm{C}$., in the Cassandra zone $6^{\circ} \mathrm{C}$., in the tamarack zone $3^{\circ} \mathrm{C}$., and the area of willows and sedges $8^{\circ} \mathrm{C}$. Ice was found at several points among the tamaracks, an inch below the 
surface. The sedge zone was covered with $\mathrm{I}$ to 3 inches $\left(25-75^{\mathrm{mm}}\right)$ of dark colored water. The other soils were wet, but their loose texture was effective in preventing a rise of temperature.

It follows that of the various situations in bog areas those most liable to extreme low temperatures in the spring are in the cassandra and tamarack zone. Since their maximum temperatures are considerably below those of neighboring areas, on quiet nights the plants there are but little protected by radiation from the soil as compared with plants of other situations.

In the following table it is shown that the soil temperatures of the several plant societies formed about a bog are different, and that each society has a characteristic temperature range. The records were made at First Sister Lake. The temperatures, given in ${ }^{\circ} \mathrm{C}$, are averages of readings made in the second inch $\left(25^{\mathrm{mm}}\right)$ below the surface. The "willow-sedge" conditions correspond to those of the ordinary swamp. The "maple-poplar" is an area of these trees on the peat substratum. The "upland" is a sandy, sod-covered area 3 feet $\left(0.9^{\mathrm{m}}\right)$ above the surface of the bog. The temperatures for the most part were taken on clear afternoons about 3 P. M. when the differences are at their maxima.

\begin{tabular}{|c|c|c|c|c|c|c|c|c|c|c|c|c|}
\hline Date $\rightarrow$ & $\begin{array}{c}\text { April } \\
4\end{array}$ & $\begin{array}{c}\text { April } \\
12\end{array}$ & $\begin{array}{c}\text { April } \\
\text { I7 }\end{array}$ & $\begin{array}{c}\text { April } \\
25\end{array}$ & $\begin{array}{c}\text { April } \\
29\end{array}$ & $\begin{array}{c}\text { May } \\
3\end{array}$ & $\underset{6}{\operatorname{May}}$ & $\begin{array}{c}\text { May } \\
16\end{array}$ & $\underset{21}{\text { May }}$ & $\begin{array}{c}\text { May } \\
27\end{array}$ & $\underset{6}{\text { June }}$ & $\begin{array}{c}\text { June } \\
\text { I5 }\end{array}$ \\
\hline Air temperature..$\ldots \ldots \ldots$ & 10. 5 & 2.0 & I0.0 & 8.5 & I8.0 & 24.0 & 27.0 & 15.0 & 26.0 & 21.0 & 26.0 & 26.0 \\
\hline 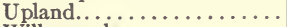 & II.O & 7.0 & 10.0 & 10.0 & 17.0 & 20.0 & 23.0 & 16.0 & 20.5 & $2 \mathrm{I} \cdot 5$ & $25 \cdot 5$ & 26.0 \\
\hline Willow-sedge........... & 7.0 & 8.0 & 8.0 & 9.0 & $14 \cdot 5$ & $17 \cdot 7$ & I9.5 & I5.0 & 20.0 & 22.0 & 22.0 & 20.5 \\
\hline 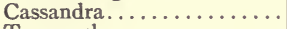 & I. 5 & 2.0 & 6.0 & $7 \cdot 5$ & II.O & $14 \cdot 7$ & I $5 \cdot 5$ & I3.0 & 16.5 & 19.0 & 20.0 & $19 \cdot 5$ \\
\hline 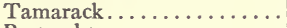 & 0.0 & 0.0 & 3.0 & $4 \cdot 5$ & 9.9 & II. 7 & 15.0 & 10.6 & 15.0 & 17.0 & r8.o & 18.0 \\
\hline Bog-sedge............. & 9.0 & 8.0 & Io.0 & 9.0 & 18.0 & ro.o & 22.0 & I6.0 & 20.0 & 23.0 & 24.0 & 23.0 \\
\hline Maple-poplar............ & 7.0 & 8.0 & 8.0 & 8.0 & 15.0 & $\mathbf{1 8 . 0}$ & 19.0 & 15.0 & I6.0 & I5.0 & 17.0 & I6. 5 \\
\hline
\end{tabular}

In the accompanying diagram ( fig. .5) it will be seen that the upland, bog-sedge, and willow-sedge soil temperatures do not deviate widely from those of the air, while the temperatures of the cassandra and tamarack areas range considerably lower. The high temperature of the bog-sedge zone finds its explanation in that the brown bog water overlying its surface absorbs heat. I have tested this point many times in various bogs and have always found such bog water to have a higher temperature than that of the saturated substratum adjoining it. In its ability to absorb heat rays it approaches that of drained sand. Its range, however, is much less and it retains its 
heat for a longer time. Consequently on cloudy days and following a sudden lowering of the air temperature, the surface bog-water temperature stands above that of the drained and undrained soil.

When we compare the effects of loss of heat from a free water surface and a saturated humus soil surface due to evaporation, there

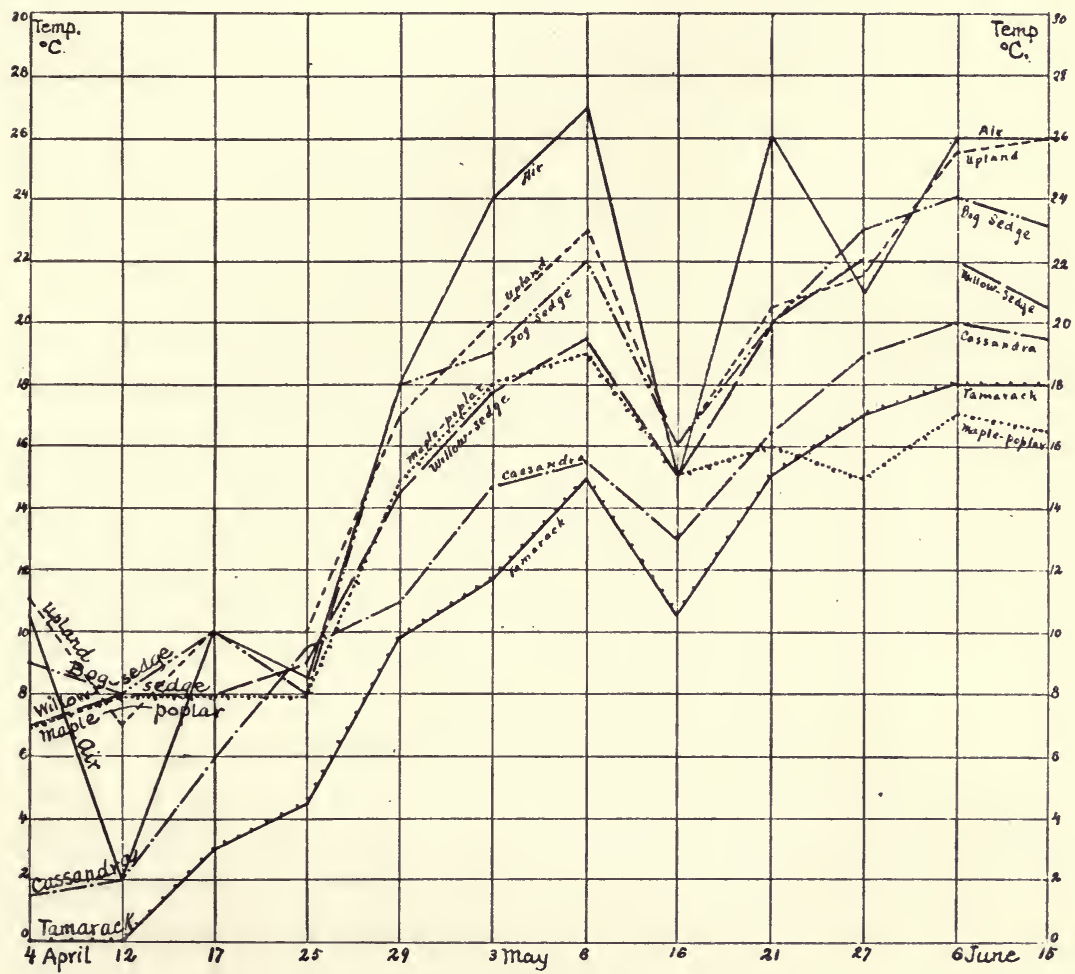

FIG. 5.-Diagram showing temperatures of the air and the substrata in the several plant societies.

is a marked difference due to their specific heat. The humus will be cooled more rapidly by the evaporation of a given amount of water. Where so large an evaporating surface is exposed to the air as in the case of a sphagnum-covered area the loss of heat by this process is most effective in preventing the penetration of heat below the surface.

In the case of drained soils, the most effective agent in raising 
the temperature of the subsoil is that of percolating water which has been warmed at the surface of the soil. Because of the high watertable and the stagnant condition of the underground water in bog areas, this source of heat is relatively unimportant.

The effects of these factors, resulting in low soil temperatures, are far-reaching. As compared with well-drained soils, chemical action is retarded, the rate of diffusion, solution, and osmosis is greatly reduced, and the conditions for the existence of soil bacteria made unfavorable. Plants which can successfully compete for the occupancy of such areas must be able to withstand low temperatures and late frosts. The difference between the temperature of the air and that of the substratum favors plants having a low transpiration ratio.

However, in so far as the region of southern Michigan is concerned, the temperatures prevailing in bog areas do not seem to be adequate to account for the presence of the bog plants or their xerophilous structures. It is to be noted that with the leafing-out of the trees, about May 27, the temperature of the maple-poplar substratum falls below that of the tamarack. But that the soil temperature is one of the factors entering into the problem of competition between species there can be little doubt. It is probable also that in the region of optimum conditions for bog plants the conditions which occur here only in the spring are prolonged through the summer. That is, the difference between air and substratum temperatures is more marked, and is a powerful factor in the selection of plants for bog areas and in the production of xerophilous structures.

3. Texture.-This property of the substratum has already been referred to in connection with the genetic changes in peat. The sedge zone is developed upon a raft of interwoven rhizomes and roots. It is a coarse meshwork; but since it lies at or below the surface of the water, its texture is of slight importance except as a means of mechanical support. As the bog develops, the admixture of moss and shrub débris brings about the formation of a rather compact peat, overlaid by a stratum of loose material. In some cases, as at Delhi and Oxford, 45 miles $\left(72^{\mathrm{km}}\right)$ northeast of Ann Arbor, the living sphagnum makes up the bulk of this loose covering. Usually the water level lies just beneath it. As a consequence, this covering becomes the 
principal seat of root activity. The small, fibrous roots of cassandra, andromeda, and the cranberry penetrate it in all directions, and it is from the water which is held among this moss and débris that they derive their water and mineral salts.

The substratum beneath the tamaracks is also covered by a loose litter of leaves and twigs, with more or less moss. Depending upon the height above the ground water level, this surface layer is of greater or less thickness. In it occur the wide-spreading roots of the tamarack. During summer and autumn it furnishes admirable conditions for the growth of fungi, and it is penetrated everywhere by their mycelia.

When bog land is cleared, the decomposition of the surface layers is very rapid, owing to exposure to sunlight and higher temperatures. If the water-table is maintained near the surface, sedges and willows develop as the covering. The annual increment of plant material is often decreased, and in place of the fibrous and porous substratum there is produced a black, close-textured, and plastic muck.

If ditching and draining are added to clearing, the summer drought dries the surface layer so thoroughly that it often becomes the habitat for many dry-ground weeds. Decay progresses in moist weather under the influences of the higher temperatures resulting from increased absorption of the sun's energy by the dark colored soil.

4. Mechanical properties.-Bog soils in general do not afford as good a foothold for the development of tree species as do the mineral soils. On account of the high water-table, the roots of the plants are not able to penetrate to a depth of more than a few inches. The roots of the tamaracks spread out in all directions from a flat trunk base, and upon the size and strength of these horizontal roots depends the tree's ability to withstand mechanical strains tending to displace it. There can be no doubt but that, in the thick groves in which the tamarack occurs, the interweaving of the roots from adjacent trees becomes of mutual advantage, in so far as the roots function as holdfast organs.

5. Diffusion properties.-A most important soil property relates to the diffusion of mineral salts. This becomes of especial significance in saturated stagnant substrata. The mineral salts must be distributed to the roots mainly by diffusion, for lateral drainage 
and percolation are at a minimum. It is well known that when salt solutions are passed through soil, much of the salt is retained by absorption. The relative amount is greatly increased in the case of humous bodies. BLANCK (4) has further found that the diffusion of water in humus soils is decreased by the presence of acid humus compounds, and that this may be corrected by the addition of a neutralizing agent, such as lime. All analyses of peat show how little of this mineral matter has been derived from the adjacent soils. It is only in the case of samples taken from the bottom or edge of a bog that the mineral salts cannot be accounted for by the amount derived from the decay of the plant material, and that obtained from the atmosphere.

6. Water-capacity. - The high water-capacity of peat has already been noted. In relation to plant growth, it is detrimental in that it prevents proper aeration of the substratum (39, p. 346). So far as the diffusion of gases is concerned, such substrata are less favorable than a free water surface. King (29, p. I6I), in speaking of sand and clay soils whose water-capacity is only 17.5 to 32.2 per cent. by weight, says that 30 to 40 per cent. of their saturation amounts must drain away before the soil can contain air enough to maintain the respiration of roots and germinating seeds. As compared with a free water surface, saturated humus cannot admit oxygen as freely, owing to the large part of the surface actually occupied by the humus (29, p. 239). In a chemical way it is still more effective, as will be noted later.

7. Osmolic pressure.-The osmotic pressure of bog waters has been found to be about the same as that of ordinary lakes and rivers. ${ }^{3}$ They are approximately equivalent to a 0.1 to 0.5 per cent. normal Knop's solution. They indicate quite certainly that bog plants do not owe their distribution and their peculiar structures to a high osmotic pressure of the bog water.

3 Four samples of bog water from this vicinity were tested by Dr. B. E. LivingSTON, of the University of Chicago, and found to have the following pressures in milli meters of mercury at $25^{\circ} \mathrm{C}$.:

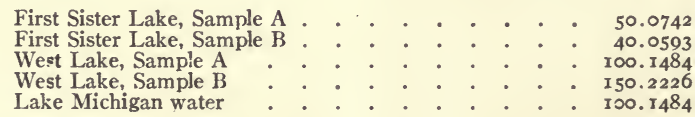

See 33. 
B. Chemical factors.- - I. Ground water.-The ground water of the Huron basin derives its mineral constituents from the glacial drift. The following analyses show the character of the solution. Quantities are expressed in parts per million (3I).

\begin{tabular}{|c|c|c|c|c|c|c|c|c|c|c|c|}
\hline & $\mathrm{CaCO}_{3}$ & $\mathrm{CaSO}_{4}$ & $\mathrm{Fe}_{2} \mathrm{O}_{3}$ & $\mathrm{MgCO}_{3}$ & $\mathrm{~K}_{2} \mathrm{SO}_{4}$ & $\mathrm{SiO}_{2}$ & $\mathrm{NaCl}$ & $\mathrm{Na}_{2} \mathrm{CO}_{3}$ & $\mathrm{Na}_{2} \mathrm{SO}_{4}$ & $\begin{array}{c}\text { Organic } \\
\text { and } \\
\text { volatile }\end{array}$ & $\begin{array}{l}\text { Total } \\
\text { mineral } \\
\text { matter }\end{array}$ \\
\hline $\begin{array}{l}\text { Ann Arbor, } \\
\text { University well. } \\
\text { Ann Arbor, } \\
\text { spring.......... } \\
\text { Ypsilanti, } \\
\text { water works.... } \\
\text { Ypsilanti, } \\
\text { well............ } \\
\text { Ann Arbor, } \\
\text { creek........... }\end{array}$ & $\begin{array}{l}178.00 \\
228.00 \\
289.00 \\
156.00 \\
128.00\end{array}$ & $\begin{array}{r}39.00 \\
223.00 \\
99.00\end{array}$ & $\begin{array}{c}3.99 \\
6.43 \\
21.00 \\
\text { Tr. } \\
\text { Tr. }\end{array}$ & $\begin{array}{r}60.58 \\
89.36 \\
100.00 \\
109.00 \\
83.00\end{array}$ & $\begin{array}{r}6.78 \\
5.31\end{array}$ & $\begin{array}{r}7.30 \\
9.20 \\
14.00 \\
18.00 \\
25.00\end{array}$ & $\mid \begin{array}{r}4.48 \\
4.88 \\
35.00 \\
62.00 \\
15.00 \\
(\mathrm{NaK})\end{array}$ & $\begin{array}{r}1.52 \\
0.42 \\
\ldots \ldots \\
17.00 \\
25.00 \\
(\mathrm{NaK})\end{array}$ & $\begin{array}{r}5.07 \\
9.7 \mathrm{I} \\
\ldots \ldots \\
\ldots \ldots \\
\ldots \ldots\end{array}$ & $\begin{array}{r}3.85 \\
25.00 \\
71.00 \\
14.00 \\
14.00\end{array}$ & $\begin{array}{l}267.72 \\
353.31 \\
498.00 \\
585.00 \\
375.00\end{array}$ \\
\hline
\end{tabular}

It is to be noted that they are all high in calcium and magnesium content, and under favorable drainage conditions contain sufficient minerals for plant growth. The ground water is of especial importance in the early stages of bog development, when the sedge and aquatic vegetation is dominant. With the further development of the sedge zone and the formation of a thick peat deposit, its relation to the vegetation becomes of less moment. There is a notable difference between the total mineral content of bog water and that of the soil waters adjoining. In the above table the total mineral content of the ground water varies from 267.7 to 585 parts per million. In three analyses of the bog water at the First Sister Lake I found the total mineral content to vary from 89.9 to 219 parts per million, the highest figure being that for the sample obtained near the margin of the tamaracks, $i$. e., nearest the mineral soil.

The absence of sphagnum from certain bogs has been explained by the presence of calcium salts (15, p. 23, I6). In order to test this point, I have cultivated the species found in this vicinity in tap water and in a saturated solution of $\mathrm{CaCO}_{3}$, and have found no detrimental effects due to calcium. The experiments will be discussed later. I further found that the ash of sphagnum growing at First Sister Lake contained $\mathrm{I} 8$ per cent. of $\mathrm{CaO}$. It would seem, therefore, that, in so far as this vicinity is concerned, the presence of calcareous waters will not explain the absence of species of sphagnum. 
2. Acidity.-Much stress has been laid by various authors, following Schimper (44, pp. 6, I8, I24), upon the acidity of the bog water as a factor in the bog habitat. In order to get a quantitative statement of the acidity for the bogs of this vicinity, a number of $50^{\mathrm{cc}}$ samples have been titrated with an $n /$ Ioo solution of potassium hydrate Phenolphthalein was used as an indicator. The results show an acidity varying from $.000 \mathrm{I} 5$ to .00258 normal acid. ${ }^{4}$ The lowest values are found in the areas occupied by bog sedges and by swamp plants, and they are practically the same. The areas occupied by cassandra and sphagnum have a somewhat greater acidity. The highest percentages are found beneath the tamaracks. The explanation of these variations in acidity is suggested by the tests, made from time to time, of the water in my experimental cultures. I found that the acidity of the water increased slowly in the undrained peat substratum cultures (see experiments). The increase was small in the case of the warm cultures, but quite notable in the case of the cold undrained substratum. On exposure to air in the water cultures, and in bottles, the acidity very slowly decreased, the decrease being greatest in the case of the water which was kept warm. This is probably due to increased oxidation. These relative amounts of acid, it will be seen, may be correlated with the temperatures in the several plant societies of the bog, the lowest temperatures corresponding to the highest percentages of acid. This suggests the probability that the acidity of the bog substratum increases farther north.

On allowing open dishes of bog water to stand for some time, I found that the evaporation was not sufficient to raise the acidity of the water, oxidation apparently being more rapid than concentration of the solution.

There is no apparent relation between color and acidity, although the lightest colored solutions usually show but slight acidity. This seems to indicate that only a part of the color is produced by free humus acids, the remainder by humates of the alkalies.

4 Following are the determinations expressed in fractions of a normal acid solution:

First Sister Lake: sedge zone, .00066, .00094; cassandra zone, .00152, .00119; tamarack area, .00165, .00179, .00227, .00258; willow-sedge area, .00089, .00072.

Chelsea: ditches, .00086, .00015, .00043, .00019, and .00029.

Delhi: tamarack area, .00146, cassandra zone, .00117.

Oxford: cassandra zone, .00094. 
The effect of acidity upon cultivated plants has been investigated in this country especially at the Rhode Island Agricultural Experiment Station, under the direction of Professor H. J. WheELer. The experiments have been conducted upon "acid upland soils" (6o), and numerous reports have been published. These experiments involved a great variety of plants and were carried on under natural field conditions. The areas planted for comparison had their acidity neutralized by the addition of $\mathrm{CaCO}_{3}$. The plants which were favored by the liming include the orange quince, black Tartarian cherry, Japan plum, Tilia americana, Ulmus americana, rhubarb, Australian salt-bush, hemp, barley, oats, onions, Anthoxanthum odoratum, Poa pratensis, Festuca ovina, Holcus lanatus, Festuca elatior, Alopecurus pratensis, etc. Plants which"appear to be adapted to the acid soil conditions include cranberry, blackberry, raspberry, sheep sorrel, cow-pea, flax, corn, lupine, and soja bean. It would appear, then, that the acidity of the soil solution is unfavorable for the growth of some plants, and that it is a factor in the selection of species for acid soil conditions.

3. Food material.-As to the presence of plant food materials in the bog soil there is an agreement among all the analyses that have been made. ${ }^{5}$ The soils are unusually rich in nitrogenous materials, some analyses showing three times as much as good upland soils. But in the slow decay of the vegetable matter the nitrogen remains bound up in organic compounds and is unavailable for the growing plants. This is confirmed by experimental tests in which nitrogen was directly applied, and by tests in which the conditions were modified so as to permit the action of nitrifying bacteria. In such cases crops were produced when the untreated humus produced none.

Under natural conditions the growth of the nitrifying bacteria in bog soils is almost impossible. Three factors work against their activity: (I) the acidity of the soil solution; (2) the lack of oxygen due to high water content; (3) the lower temperature. It has been found that the optimum temperature for these bacteria is $98^{\circ} \mathrm{F}$. $\left(36.6^{\circ} \mathrm{C}\right.$ ) $)$, and that their activity is very slight at $50^{\circ} \mathrm{F}$. (10 ${ }^{\circ} \mathrm{C}$.)

5 Analyses of Wisconsin soils. Ann. Rept. Wis. Agric. Exper. Sta. 13: 304. 1896. See also 27, p. I2; 23; 22, p. 276; 30; 48, p. 234; 1 2, p. 39; 14. 
(3). Furthermore, it has been shown that when soil rich in nitrogen is saturated with water so as to exclude free oxygen, denitrification takes place and nitrogen gas is set free (29, p. II 5$)$.

The phosphoric acid content is comparable with that of the best soils, and it is at least partially in a condition for plant use.

The potassium content is very low. Analyses and the results of agricultural experiments show that in order to produce crops this substance must be added, and preferably in an alkaline form. Inquiry among the owners of onion marshes in this vicinity confirms the need for potassium in local bog soils.

The amount of calcium present is reported as equal to that of the best upland soils. But it is probable that as it exists under natural conditions in bogs it is bound up largely in insoluble humates. Under the influence of oxidizing processes it would become available to the plants at the surface.

When we consider the conditions under which the various plant societies in our bogs exist and their competition with one another, there can be little doubt but that the substratum varies in each case as to its chemical composition. That the societies may be classified on a physiographic basis is certain, but how to determine the chemical factors accompanying each physiographic change is an unsolved problem. The ordinary methods of analysis give us the minerals present, but tell us little about their form and availability for plant assimilation. The colorimetric methods for determining the quantity of mineral salts present in bog water are mostly open to objection. The ease with which the humous bodies of the bog water are decomposed render their quantitative estimation by present methods of little value. Yet it seems probable that work upon the chemistry of humus and humous compounds must result in data valuable alike to the ecologist, the forester, and the agriculturist.

C. BIOTIC FACTORS.-The interrelations of the bog species will be discussed in connection with their other ecological characters. It will be sufficient to mention here that they are with a few exceptions light-demanding forms. Consequently, size and ability to produce șade are the important factors in their competition with one another.

A second element enters into this problem of the struggle between 
species near the borders of the area of geographic distribution of the bog plants, viz., climate. The bog plants of this vicinity come into conflict with species whose range is either more nearly continental or more southern. That the climatic and edaphic conditions of this region are at present unfavorable to the successful competition of the bog species with swamp species is evidenced wherever the bog conditions have been disturbed. That the reverse is the rule in eastern Canada has been shown by Ganong (I8, p. I78). The tenacity with which species, whose multiplication is principally accomplished by vegetative means, hold an area under complete control is apparent to any who have studied the vegetation of lake shores. It is just as strongly marked in the case of the herbaceous and shrubby bog vegetation. When we examine the chemical and physical data, now at hand, concerning the soils occupied by bog and swamp plants respectively, the conclusion must be that they are wholly inadequate to account for the difference in vegetation. The forester lays stress upon the fact that trees cannot gain a foothold on areas now covered with a grass turf because of the difficulty of the seedlings getting started. The bog societies form an equally compact plant growth, and their preservation in this region would seem to be dependent upon analogous factors.

\section{The bog-plant societies.}

The following descriptions of local bog areas occurring in the Huron valley aim not only to present lists of plants found in this vicinity, but to show their natural associations. The order in which the areas are described corresponds to the relative amount of filling which has occurred in the several basins. To a certain extent this order is genetic, yet there can be little doubt but that many arctic plants which were concerned in the pioneer stages of our mature bogs are now extinct. If we accept the areas at West and First Sister Lakes as representing bogs in youth, maturity may be illustrated by the original vegetation of the bog on Carpenter's road. The Chelsea area defines that stage beyond the climax, when the conditions inaugurated by cutting, firing, and ditching have destroyed the original tamarack forest, and in its place has come a rude mixture of bog relicts and arborescent weeds. 
WEST LAKE.

This lake, situated three miles north of Chelsea (Sec. 30, Dexter Tp.), is also known locally as Johnson's Lake. In area it is slightly more than a fourth of a square mile ( 65 hectares). The margin of the lake originally extended a half mile $\left(0.8^{\mathrm{km}}\right)$ farther west and southwest. This part is now occupied by a partially floating bog. The north, south, and east shores are sandy and low. Patches of bulrushes and water-lilies occur here and there over the lake and show its generally shallow character. Toward the east there is a narrow swampy outlet by which its water after a long and circuitous route reaches the Huron River. There are no streams tributary to the lake. The basin lies near the southeastern margin of the interlobate moraine, and is bounded on the north and south by hills 60 to 80 feet $\left(\mathrm{I} 8-24^{\mathrm{m}}\right)$ in height. Not all of the original extension to the southwest has been filled by peat; two small areas of open water still remain.

The shores, with the exception of the western side, support a vegetation similar to that of many lakes in this region. Three societies of plants may be distinguished.

Aquatics.-The most abundant plants are Scirpus lacustris, Castalia tuberosa, and Sagittaria rigida. These occur not only along shore, but in shallow water throughout the lake. Associated with these are Naias flexilis, Brasenia purpurea, Potamogeton heterophyllus, Chara (sp.), Spirodela polyrhiza, Vallisneria spiralis, Scirpus americanus, and Decodon verticillatus.

Sedge-grass society.-Very near the north, south, and east shores occur a great number of species of grass-like plants. Their associations vary greatly at different parts of the shore line. The dominant forms are Carex filiformis, Panicularia nervata, Eleocharis palustris, Carex teretiuscula, C. Muskingumensis, Dulichium arundinaceum, Panicularia Canadensis, Dryopteris Thelypteris, and Scutellaria galericulata. Among the species of secondary importance are Onoclea sensibilis, Carex riparia, C. stipata, C. hystricina, C. interior, Spartina cynosuroides, Typha latifolia, Iris versicolor, Lobelia Kalmii, Comarum palustre, Lycopus americanus, and Eupatorium maculatum. Closely associated with these plants are the seedlings of the shrubs and trees which make up the next society.

Willow-maple society. - The shrub and tree border is composed, 
for the most part, of Salix Bebbiana, S. discolor, S. sericea, Cornus candidissima, Acer rubrum, and Ulmus americana. Beside the many plants of the sedge-grass society which remain as relicts, the accessory species include Rosa Carolina, Impatiens biflora, Sambucus pubens, Spiraea salicifolia, Prunus serotina, Quercus alba, Q. velutina, and Opulaster opulifolius. These trees grade into the forests of the upland and establish a natural order of succession.

An interesting comparison is afforded when we note the species dominant along the western or bog margin. Here the outer zone of aquatics is made up of the same species, but this substratum is a floating raft constructed by the plants themselves. Without again enumerating the species, we pass to the society which closely follows their development.

Bog-sedge and shrub society.-This society forms a very complex growth, averaging 50 feet $\left(\mathrm{I}_{5}^{\mathrm{m}}\right)$ in width. On the lakeward side are the aquatics; on the other, the growth of tamaracks. The sedges and shrubs are not separable, as in many other localities. Carex filiformis is by far the most important plant in the society. Its vigorous production of rhizomes and roots especially fit it for the position which it occupies. Certain other plants are locally abundant and of great consequence. These include Dryopteris thelypteris, Menyanthes trifoliata, Eleocharis palustris, Comarum palustre, Sagittaria latifolia, Eriophorum polystachyon, Carex teretiuscula, Typha latifolia, Salix myrtilloides, S. candida, Betula glandulosa, ${ }^{6}$ Oxycoccus macrocarpus, and Andromeda polifolia. As accessory species may be mentioned Salix discolor, S. Bebbiana, Cicuta bulbifera, Cardamine pratensis, Chamaedaphne calyculata, Campanula aparinoides, Rumex Britannica, Epilobium adenocaulon, Asclepias incarnata, Pogonia ophioglossoides, Blephariglottis blephariglottis, Limodorum tuberosum, Marchantia polymorpha, Aulacomnium palustre, Sarracenia purpurea, Drosera rotundifolia, Boehmeria cylindrica, Carex comosa, C. hystricina, Cornus stolonifera, Parnassia caroliniana, Viola blanda, and Penthorum sedoides. Here and there occur young tamaracks which by their growth inaugurate the next society.

Tamarack society.-As development proceeds, the shrubs and

6 The form found here and at Delhi corresponds more closely to this species than to $B$. pumila, but its characters are intermediate. 
herbs gradually are superseded by a growth of Larix. This society has been much disturbed by lumbering, and a large part of the original area has been cleared. But there is good evidence to show that the part of the basin filled with peat formerly supported a dense covering of tamaracks. Where best developed and least disturbed, it shows an undergrowth of Vaccinium corymbosum, Aronia nigra, etc. As the other species are practically the same as at the lake to be described next, they need not be enumerated here. In contrast with most of the areas studied, the almost complete absence of sphagnum is worthy of note. It is also important that the absence of any gradation between the forest societies of the upland and of the bog be kept in mind.

On this lake, then, there are two divergent series of plant societies. Starting with practically the same species, the one series leads us on mineral soil through willows, maples, and elms to the oaks of the surrounding forests; the other, owing to the development of a floating substratum, involves a very different set of shrubs and ends with the tamarack. The former series therefore more closely approximates the climatic type, while the latter is dependent upon edaphic factors.

\section{FIRST SISTER LAKE.}

This lake and its accompanying bog are located three miles west of Ann Arbor in a glacial drainage valley. Its origin is probably connected with the melting of a mass of stagnant ice after the abandonment of the valley by glacial drainage. The surrounding and underlying soil is a sandy gravel. At least a part of the western side presents an original tamarack bog vegetation, and it is particularly interesting in showing the results of competition between bog plants and those of other habitats (fig. 6). The vegetation in general presents a different phase of the bog societies, as compared with West Lake. Especially to be noted are the dominance of cassandra and sphagnum in the shrub zone, the absence of cattails and swamp loosestrife as important members of the outer margin. The tamarack zone is also raised somewhat more above the water level.

Aquatics.-With the exception of the shallow-water forms, the lake is almost free of higher vegetation. Potamogeton lucens and P. zosteraefolius occur sparingly. About the margin, however, 
Nymphaca advena is of great importance. It forms an almost continuous zone 1o to 25 fect $\left(3-7 \cdot 5^{\mathrm{m}}\right)$ in width. Patches of Castalia tuberosa and Brasenia purpurea occur. This arrangement in groups seems to be connected with their rapid multiplication by rhizomes. Typha latifolia occurs in a small area at the north end of the lake. Ceratophyllum demersum and Naias flexilis occur as secondary species.

Bog-sedge society.-Carex filiformis, C. oligosperma, Eleocharis palustris glaucescens, and Eriophorum polystachyon are the primary factors in the formation of this zone. Carex riparia has gained a foothold at the north end of the lake, where muskrats have been active in destroying the original sedge zone. Dryopteris thelypteris, Onoclea sensibilis, Juncus effusus, J. canadensis, Comarum palustre, Salix myrtilloides, Dulichium arundinaceum, Equisetum fluviatile, Bidens trichosperma tenuiloba, Menyanthes trifoliata, Viola blanda, and Eriophorum virgini-

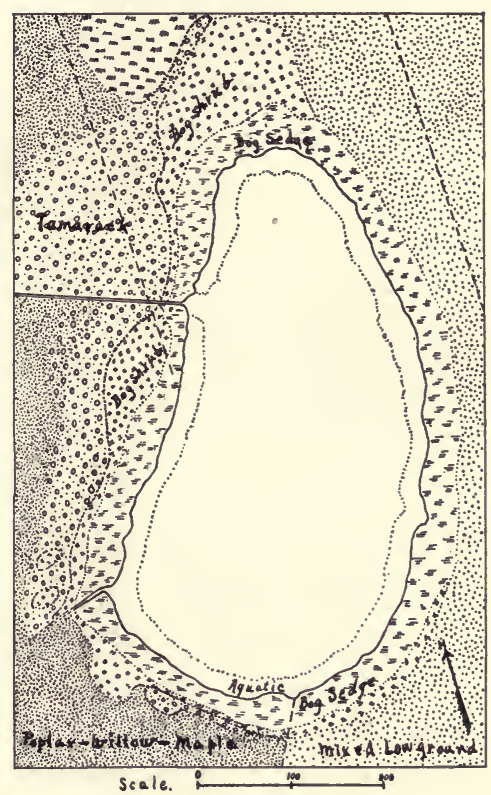

FIG. 6.-First Sister Lake. cum occur as accessory plants. The great majority of these plants aid in the construction of the substratum by their roots and rootstocks.

Here and there among the sedges occur the forerunners of the shrub society. Among the very first to gain a foothold are the sphagnums. These build small tufts of great compactness, and gradually overcome the sedges. The rootstocks of the cassandra also send up shoots and prepare the way for another vegetation form. Oxycoccus macrocarpus and $\mathrm{O}$. Oxycoccus both occur at intervals in this zone.

Cassandra-sphagnum society.-Beyond the sedge zone the vegetation is no longer arranged zonally. Conditions have been so much 
disturbed that on the western side the area of cassandra-sphagnum dominance is very irregular. On the eastern side this plant society is in the last stage of its existence. The intimate association of Chamaedaphne calyculata, Sphagnum cymbifolium, S. subsecundum, and S. recurvum is well illustrated here. The plants occupy the whole of the territory where they flourish. The other species are decidedly secondary. It is to be further noted that in the competition with the sedge species these plants actually override them, and only an occasional Eriophorum virginicum survives. The water-conserving properties of the sphagnum are too well known to need description here. But the mutual advantage of the cassandrasphagnum combination is worthy especial note. The former by its numerous branches furnishes a framework which aids in the upbuilding of the moss and in shading. The sphagnum, on the other hand, furnishes a moist cover in which the conditions for the shrub are most favorable.

The accessory species include the moss, Aulacomnium palustre; the herbs, Drosera rotundifolia, Arethusa bulbosa, Habenaria lacera, Sarracenia purpurea, Pogonia ophioglossoides, Limodorum tuberosum, Viola blanda, Osmunda regalis, Campanula aparinoides, Scutellaria galericulata; and the shrubs, Andromeda polifolia, Betula pumila, Oxycoccus macrocarpus, O. Oxycoccus, Aronia nigra, and Ilicioides mucronata.

Tamarack society.-Among the cassandra occur many young tamaracks, and these by their development come to overshade the shrubs and form the tree society of the bog. The dead remnants of the cassandra mounds make up a large part of the floor beneath them. The species of secondary importance are Ilicioides mucronata, Aronia nigra, Chamaedaphne calyculata, Osmunda cinnamomea, O. regalis, Dryopteris spinulosa intermedia, D. cristata, Polytrichum juniperinum, Plagiothecium denticulatum, Thuidium recognitum, Aulacomnium palustre, Marchantia polymorpha, Sphagnuin cymbifolium, Boletinus porosus, and Thelephora intybacea.

The tamarack zone has been much disturbed by clearing and burning. At the present time a large part of the area on the southwest side is dominated by other tree species. Some of the plants of the clearing have spread into the pure tamarack growth. 
Poplar-willow-maple society.-Where the original conditions have been disturbed and a second growth allowed to come in, Populus tremuloides, Salix sericea, Salix discolor, and Acer rubrum have obtained dominance. Where groups of the more mature poplars occur there is scarcely any undergrowth. Elsewhere the following plants occur: Ilicioides mucronata, Salix Bebbiana, Sambucus pubens, Amelanchier oligocarpa, Aronia nigra, Rubus nigrobaccus, Cornus stolonifera, and Rubus strigosus. These form a dense mixed association, with but slight reference to substratum conditions. The smaller species present are Adicea pumila, Osmunda cinnamomea, Rosa Carolina, Onoclea sensibilis, Epilobium adenocaulon, Spiraea salicifolia, Dryopteris thelypteris, Verbena hastata, Solanum dulcamara, Polygonum sagittatum, Spiraea tomentosa, Geum rivale, Polygonum hydropiperoides, Ribes floridum, Ribes oxyacanthoides, Rumex Britannica, Impatiens biflora, Viola blanda, Osmunda regalis.

On the southeast side of the lake and on the north, conditions have been still more interfered with, and there is now a mixed growth of bog and low-ground plants, which represent stages in the decline of the bog flora and the advent of swamp plants. The tallest forms are willows and clumps of mountain holly. For convenience only, the plants may be enumerated together under the following title:

Mixed low-ground society.-The dominant plants are Salix sericea, S. discolor, Spiraea salicifolia, Poa flava, Solidago serotina, Chamaedaphne calyculata, Oxycoccus macrocarpus, Aster NovaeAngliae, and Rosa Carolina, Epilobium adenocaulon, Aronia nigra, Andromeda polifolia, Rubus strigosus, Dryopteris thelypteris, Scutellaria galericulata, Juncus effusus, Koellia virginiana, Sambucus canadensis, Geum rivale, Osmunda regalis, Scirpus cyperinus, Galium aparine, Homalocenchrus oryzoides, Juncus tenuis, Asclepias incarnata, Salix Bebbiana, Eupatorium perfoliatum, Gentiana Andrewsii, Lycopus virginicus, Osmunda cinnamomea, Cornus stolonifera, Carex riparia, Viola blanda, Sarracenia purpurea, Dryopteris cristata, D. spinulosa intermedia, and Triadenum virginicum also occur.

The last two societies are found upon a black peat substratum which is more thoroughly decayed than in other parts of the bog. 
Acidity tests show that the relative acidity is less than in the case of the cassandra-sphagnum and tamarack societies. The soil temperature also runs somewhat higher as noted elsewhere.

The First Sister Lake may be said to be dominated by three wellmarked bog and two mixed societies in which bog and swamp species are brought into competition. The result can be

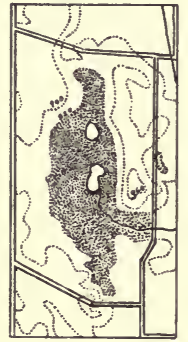

FIG. 7.-Delhi bog and adjacent topography. Scale I : 95,000 ( $\frac{2}{3}$ inch $=\mathrm{I}$ mile). foretold with considerable certainty. The bog vegetation will sooner or later be replaced by the swamp species.

\section{BOG NORTH OF DELHI.}

Two miles north of Delhi occurs an extensive bog which was formerly a mile and a quarter $(2 \mathrm{~km})$ long by a half mile wide $\left(0.8^{\mathrm{km}}\right)$ at its broadest part (fig. 7). The southwestern third has been cleared and is in part under cultivation. The eastern and northern parts have been somewhat interfered with by the cutting of timber, but areas occur which have been but little disturbed by these influences. Near the eastern margin are two small lakes, the last remnants of the larger lake which must have occupied this territory in early postglacial times. The basin is located in a clay moraine of the Erie ice-lobe, and probably owes its origin to unequal deposition by the glacier.

The plant societies found about the southeastern lake will give an idea of the whole vegetation (fig. 8).

Aquatic society.-The aquatic vegetation is represented almost wholly by the yellow water-lily, Nymphaea advena. This plant forms a broader zone completely encircling the lake and varying from 5 to to feet $\left(\mathrm{I} .5^{-} 3^{\mathrm{m}}\right)$ in width. Accompanying it occur Brasenia purpurea, Ceratophyllum demersum, Lemna minor, and Spirodela polyrhiza.

Typha-cassandra-sphagnum society.-On the floating margin of the bog substratum occurs a zone which partially encircles the lake. Near its outer edge Typha latifolia is the characteristic plant, but in certain places it is wanting or extends the full width of the zone. Chamaedaphne calyculata, Sphagnum cymbifolium, S. subsecundum, S. recurvum, Carex filiformis, Eriophorum polystachyon, and Salix 
myrtilloides are the most frequent plants. The accessory species include Carex oligosperma, Menyanthes trifoliata, Comarum palustre, Triadenum virginicum, Osmunda regalis, Onoclea sensibilis, Rumex Britannica, Asclepias incarnata, Viola blanda, Cicuta bulbifera, Galium Aparine, Scutellaria galericulata, Rhus Vernix, Dulichium arundinaceum, Oxycoccus macrocarpus, Hypnum cordifolium, Hypnum Schreberi, Aulacomnium palustre, and Mnium.

Vaccinium-aronia society. -Forming a narrow transition society between the low shrub zone just described and the tree society, occurs a dense line of tall shrubs. The dominant species are Vaccinium corymbosum, Gaylussacia resinosa, Aronia nigra, Ilicioides mucronata, Betula glandulosa, and Prunus serotina. The other species present are Acer rubrum, Sambucus pubens, Os-

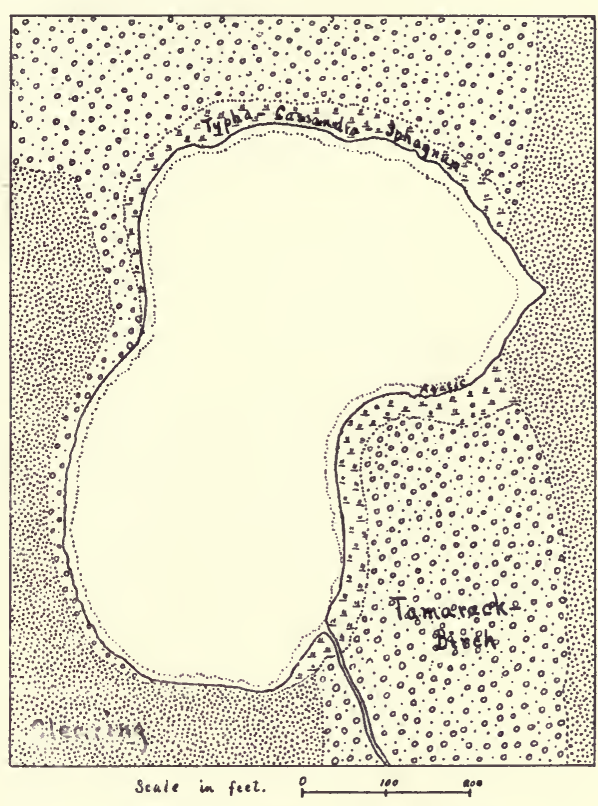

FIG. 8.-Portion of Delhi bog. munda cinnamomea, Salix discolor, S. Bebbiana, Spiraea salicifolia, Ilex verticillata, Rosa Carolina, Sarracenia purpurea, Andromeda polifolia, Calamagrostis canadensis, and Eleocharis palustris glaucescens. These shrubs border the tamaracks and to varying distances extend back among them.

Tamarack-birch society.-Larix laricina and Betula lutea must have made up the great bulk of the original forest which occupied this area. The relative abundance of the latter has probably been increased by the cutting of the tamarack. The next most important tree is Acer rubrum, which occurs scattered throughout, but is especially abundant near the northeast side. Where isolated trees have been removed, the shrubs which occur among the undergrowth have 
made a rapid growth. Throughout the forest area are patches in which Aronia nigra, Vaccinium corymbosum, and Ilicioides mucronata stand so thickly as to be almost impenetrable. Where the forest has been but slightly disturbed and the tamaracks are more or less scattered, one finds a deep carpet of sphagnum with slender stems of cassandra, andromeda, and Eriophorum virginicum rising through it. Clusters of Sarracenia purpurea are common. The other plants found in this society are Trientalis americana, Unifolium canadense, Coptis trifolia, Rumex Acetosella, Rubus strigosus, Dryopteris spinulosa intermedia, Osmunda cinnamomea, Viola blanda, Impatiens biflora, Solanum dulcamara, Thelephora intybacea, Polytrichum juniperinum, Sambucus pubens, Agrostis alba, Blephari glottis lacera, Cornus candidissima, and Cicuta maculata.

Clearing society.-Surrounding the forest on the east, south, and west sides is a large area, in part dominated by sedges and grasses, and in part by a typical "slashing." It is impossible to characterize this plant association by any particular species. All that have been thus far mentioned occur in scattered clusters, the proportions and dominant plants varying from one locality to another. The notable facts are that on the east side Carex teretiuscula, C. vulpinoidea, C. riparia, C. filiformis, Scirpus cyperinus, Calamagrostis canadensis, Aster Novae-Angliae, Eupatorium perfoliatum, and Aster junceus have become the most abundant forms. To the west of the lake these plants are present, but the taller shrubs are in control. Salix discolor, Cornus stolonifera, Salix Bebbiana, S. sericea, and many others already mentioned as occurring among the tamaracks are present.

The second lake and the more northerly one is bordered by an exceedingly narrow zone of low-growing plants. The dominant species are Decodon verticillatus and Typha latifolia. Chamaedaphne calyculata, Carex riparia, Panicularia canadensis, and Bromus Kalmii are of secondary importance. The trees come almost to the water's edge. The proportion of red maples among the tamaracks and birches is considerably greater than in the vicinity of the other lake. Otherwise the tree society is essentially the same.

We have illustrated, then, in the bogs at West Lake, First Sister Lake, and Delhi, three stages in the filling of old lake basins. We 
have seen that, although there are minor variations in the species present, all of the bogs show a series of bog-sedge, shrub, and conifer societies which are genetically related. In the Delhi bog the filling is almost completed. In the bog about to be described we find this process finished, and what was formerly a ring of bog-sedges surrounding an open lake has become an irregular disk forming the central plant society of the area.

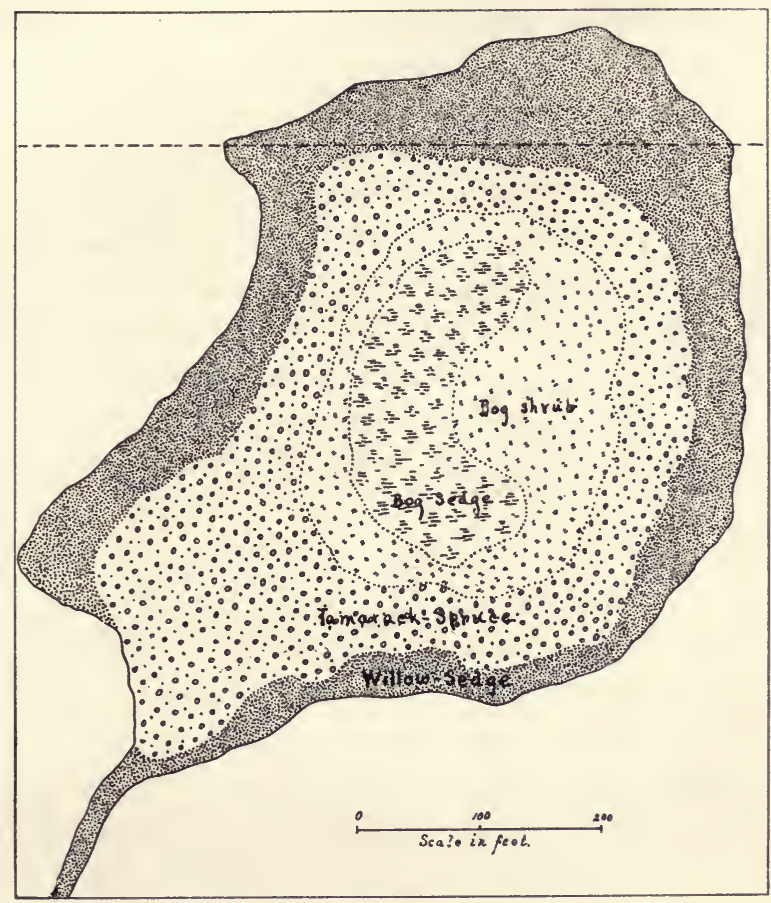

FIG. 9.-Bog near Oxford, Oakland county.

\section{BOG NEAR OXFORD, OAKLAND COUNTY.}

Near the northeast corner of Sec. 3I, Oxford Tp., there is a bog (fig. 9) covering about 4.5 acres (I.8 hectares). Although it lies a few miles beyond the real boundary of the Huron River basin, it is included because it exhibits a flora somewhat different from the other areas, and may be considered as a near approach to the type of bogs occurring farther north. The basin is a depression in the outwash sands and gravels of the interlobate moraine. It is sur- 
rounded by hills 25 to 30 feet $\left(7 \cdot 5^{-9^{\mathrm{m}}}\right)$ in height above the bog level. During wet weather it has a shallow outlet to the southwest. The land surrounding it has all been cleared and is now under cultivation. As shown by other timber areas in the vicinity, it is probable that the original upland timber was made up in part of Pinus strobus, Quercus coccinea, and Betula papyrifera.

Bog-sedge society.- Toward the center of the bog is a considerable area in which the water level lies just at the surface. The sphagnum is for the most part submerged, and the dominant plants are Carex oligosperma and Scheuchzeria palustris. Occasional plants of the following society are scattered throughout.

Bog-shrub society. - While this zone is characterized by Chamaedaphne calyculata, Sphagnum cymbifolium, S. recurvum, and S. subsecundum, young and dwarfed specimens of the spruce, tamarack, and pine are present in large numbers. The surface formed by the sphagnum is exceedingly rough and marked by hummocks. Among the depressions Eriophorum virginicum, E. vaginatum, Andromeda polifolia, Sarracenia purpurea, and Oxycoccus macrocarpus are abundant.

Tamarack-spruce society.-This society forms a zone completely surrounding the shrub society, and is dominated by trees of Larix laricina and Picea Mariana. Occasional specimens of Pinus Strobus are found, especially toward the southwest corner, where the substratum is somewhat higher than elsewhere. Beneath the trees is an almost impenetrable tangle of shrubs, especially Vaccinium corymbosum and Ilicioides mucronata. The substratum is practically bare of lower vegetation. An occasional mat of Aulacomnium palustre may be found at the tree bases. That this society will come into possession of the central bog area is certainly indicated by the great numbers of young trees among the bog shrubs.

Willow-sedge society.-As usual in the clearing of the adjacent land, the larger trees of the bog margin were also removed, and in their stead has come up a growth of willows. The dominant plants of this zone are Salix sericea, Cornus stolonifera, Spiraea salicifolia, Salix discolor, Carex riparia, and C. stipata. Associated with these plants are Sambucus pubens, Salix nigra, Iris versicolor, Populus monilifera, Dryopteris spinulosa intermedia, Osmunda cinnamomea, 
Equisetum limosum, Cornus candidissima, Aronia nigra, Rosa Carolina, Juncus effusus, Calamagrostis canadensis, Rubus strigosus, Ilicioides mucronata, Comarum palustre, Carex filiformis, Panicularia canadensis, and Poa flava. Forming a high border about the tamaracks and spruces are numerous large plants of Vaccinium corymbosum and Ilicioides mucronata.

The very marked difference between the vegetation of the central and marginal parts of the bog are worthy of especial note. The former represents the original vegetation of the bog. The latter illustrates most forcibly that under present conditions a very different set of plants springs up and becomes dominant, in spite of the fact that the true bog plants were near at hand when the clearing occurred. This bog also illustrates that stage in the filling of a depression immediately following the disappearance of the lake.

In other bogs near Oxford, Dasyphora fruticosa and Chiogenes hispidula occur among the shrubby growth.

\section{THE DELHI MUSKEAGS.}

In the bog north of Delhi which has already been described occur two areas, somewhat to the west of the lakes, which seem to represent a later stage in the history of a bog than that shown by the lakes. These areas, if they were found in northern Michigan, would be termed "muskeags." They are surrounded by large tamaracks, and small tamaracks occur throughout, the smallest specimens toward the center. If the bog at Oxford were to continue its work of filling until the central society disappeared, we should have a bog area of much the same appearance. The small tamaracks stand far apart, and between them is a most luxuriant growth of cassandra and sphagnum. The hummocks rise between 3 and 4 feet $\left(0.9^{-\mathrm{I} .2^{\mathrm{m}}}\right)$ above the substratum. As one attempts to traverse these areas, he sinks knee-deep in the long, fibrous, peat moss.

The total number of species is very small, and includes, besides those already mentioned, Andromeda polifolia, Sarracenia purpurea, Oxycoccus macrocarpus, and a few specimens of Vaccinium corymbosum.

\section{BOG ON CARPENTER ROAD}

This bog is situated in the SW. $1 / 4$ Sec. 36 , Ann Arbor Tp. Its basin is a small depression in the glacial moraine occupying about 
one-tenth of an acre (fig. Io). On the south, west, and north sides it is bordered by clay hills which rise 25 to 40 feet $\left(7 \cdot 5^{-12} 2^{\mathrm{m}}\right)$ above the bog level. The vegetation of the hills is dominated by Quercus velutina, Q. alba, and $\mathrm{Q}$. rubra. With these trees occur Hicoria ovata, Hamamelis virginiana, etc.

On the north side the upland has been cleared, and the land is now under cultiva-

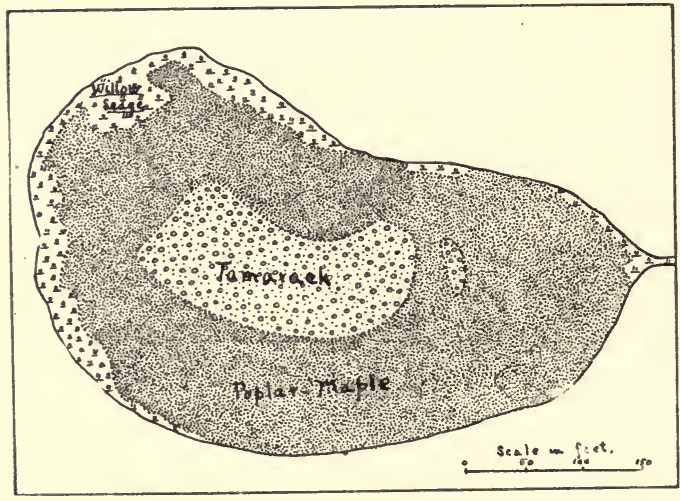

FIG. Io.-Bog on Carpenter road. tion. From time to time tamaracks have been removed from the bog, until at the present time only the central area remains to indicate the original covering. Accompanying the clearing there has grown up about the tamaracks the usual thicket of shrubs and young trees. As elsewhere, the peat is more thoroughly decayed and the substratum level somewhat lower about the margin than toward the center. This fact is of importance in differentiating the willow-sedge society.

Tamarack society.-This society is dominated by the group of rather mature tamaracks. The substratum has the characteristic hummocky surface, marked by large exposed roots, common to such areas. It is overlaid by a loose covering of vegetable matter, made up principally of tamarack needles. The undergrowth is sparse, but most of the bog shrubs and herbs are represented. The more important species are Chamaedaphne calyculata, Sphagnum cymbifolium, S. recurvum, S. subsecundum, Eriophorum virginianum, and Lycopus virginicus. A very noticeable growth about the bases of most of the shrubs is produced by the fungus, Thelephora intybacea. The mycelium in developing its sporophores rises about the stems, frequently to a height of a foot $\left(25^{\mathrm{cm}}\right)$. From the cylinder thus formed, irregular fan-shaped pilei are developed, which gives 
the appearance of an elongated brown rosette about the stem "bases. Clitocybe laccata and Boletinus porosus are also abundant in the autumn. The partially decayed stumps bear Peltigera canina. Other species occur in this area, but reach their dominance in the next society.

Poplar-maple society.-Here are brought together the remnant of the bog species, and those more characteristic of swamps and clearings. The trees are mainly Populus tremuloides, with a scattering of Acer rubrum. Elm seedlings occur. The shrubby plants, however, make up the bulk of the vegetation. Ilicioides mucronata, Ilex verticillata, Aronia nigra, and Vaccinium corymbosum have almost complete possession, and are struggling with one another for space. All these forms send up stems from the underground parts, so that among them the struggle is largely a mechanical one. However, where the red maple overtops them, the factor of shade enters, and the black choke-cherry and high-bush blueberry are the most tolerant. The mountain holly and black alder prevail elsewhere. The next most important plants are the willows, Salix sericea and S. discolor. Mixed with these are Cornus candidissima, Rubus nigrobaccus, Rosa Carolina, Cornus stolonifera, Spiraea salicifolia, and Rubus strigosus.

Willow-sedge society. - The area dominated by these plants is covered with water in the spring and during moist weather. Although this society is fast being crowded out by the next preceding, it is probable that only a small part of that area was ever occupied by these plants. These plants require a more moist substratum. The dominant species are Salix sericea, Carex riparia, C. stipata, Cornus stolonifera, and Osmunda cinnamomea. In the case of the cinnamon fern found in this bog there is a remarkable development of aerial roots. They are about an inch long and extend outward from the thick rootstock in all directions, forming a dense covering. The roots are thickly covered with root-hairs which have been persistent at least through one winter. The root-hairs are large and brown in color. The appearance of these rootstocks, as a whole, is very suggestive of certain tropical tree ferns. The other species present are Ranunculus abortivus, Polygonum sagittatum, Cicuta bulbifera, Prunella vulgaris, Rubus americanus, Rhus Vernix, Solanum dulca- 
mara, Impatiens biflora, Eupatorium perfoliatum, Calamagrostis canadensis, Dryopteris thelypteris, D. spinulosa intermedia, Doellingeria umbellata, Lactuca spicata, Coptis trifolia, Boehmeria cylindrica, Onoclea sensibilis, Marchantia polymorpha, and Rosa Carolina.

The further development of these societies under present conditions will bring about a complete change. There can be no doubt that the poplars and red maples are the coming trees, with elm a close third. When these have become sufficiently large and numerous to overshade the shrubs, the latter will be killed out, and we shall have in their place the maple-elm forest common to the low grounds. The shrubs, however, are capable of persisting for a great length of time, because of the difficulty of tree seedlings obtaining a start beneath them.

THE CHELSEA BOG.

Of the bogs which have been subjected to clearing, burning, and ditching, by far the most interesting in this region is located just to the southeast of the town of Chelsea. It covers an area of about 50 acres ( 20 hectares), and the peat is reported to be 40 feet ( $\left(2^{\mathrm{m}}\right.$ ) thick at the deepest places. The divisions into societies, as indicated on the map (fig. II), are based on the most general characters of the vegetation. There are gradations between all of the societies, and these are so gradual that it is difficult to determine definitely the boundaries. Further, owing to the tendency of many of the shrub species to form dense local growths by the development of stems from underground shoots, the smaller associations are very diverse in different parts of the same society.

Birch-vaccinium society.-This mixed society of bog shrubs occupies about one-fourth the area of the bog. Its substratum consists of peat standing about a foot above the average water level. The dominant plants are Betula pumila, Vaccinium corymbosum, Rubus frondosus, Aronia nigra, Vaccinium canadense, and Pteridium aquilinum. Just as common perhaps, but of lower growth, are Rubus hispidus, Spiraea salicifolia, S. tomentosa, Aralia hispida, Chamaedaphne calyculata, and Rumex Acetosella. The ground covering, except beneath the dense shade of the shrubs, is made up of Polytrichum juniperinum. There are many small areas of which this plant now holds exclusive control, and forms a rich carpet of 
green, yellow, and red, depending upon the season of the year. Where the moss is disturbed by the uprooting of plants, the substratum becomes exceedingly dry. The moss dies out, and in place of it there springs up a growth of Cladonia rangiferina, C. pyxidata,

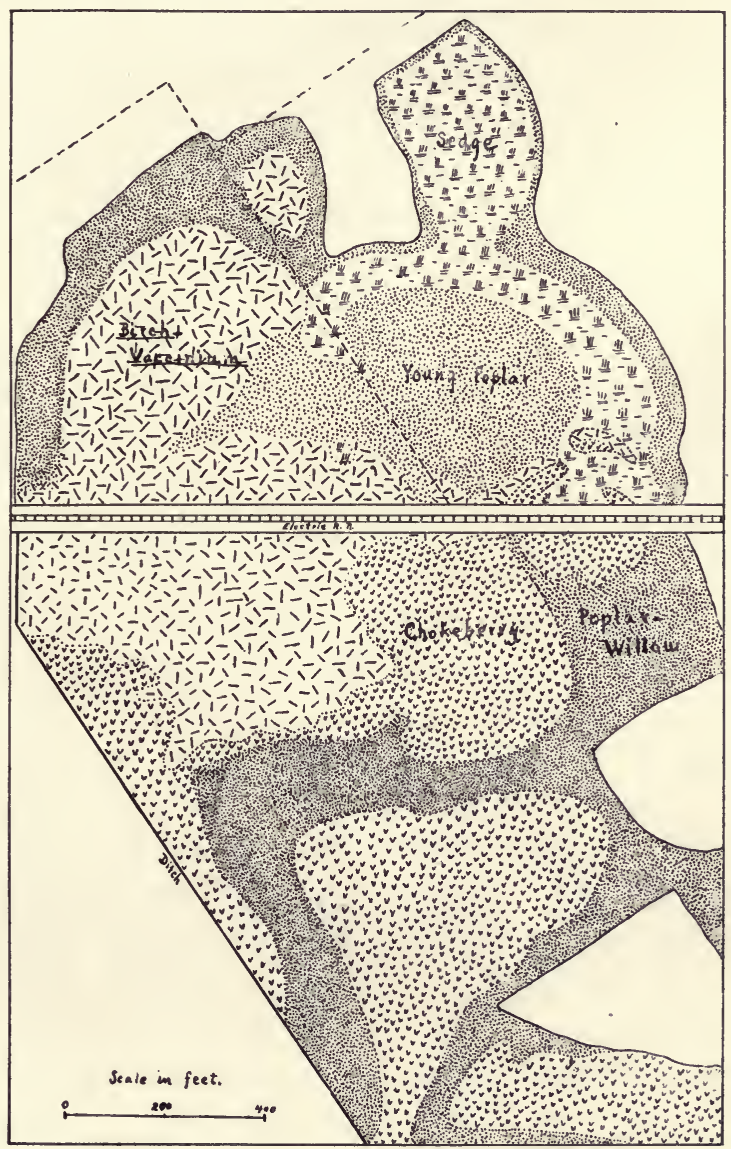

FIg. II.-Chelsea bog.

C. gracilis, C. verticillata, C. cristatella, and frequently a small admixture of Rumex Acetosella. These plants gradually close over the surface and aid in the conservation of the moisture. As the conditions become more favorable, the Polytrichum again closes over the area, driving out the lichens. About the borders of the shrubs 
the Polytrichum is killed out by the shade. Rumex Acetosella is better fitted to withstand such conditions, and consequently forms an inner border about each group of shrubs. Where depressions occur and are flooded for any length of time, the Polytrichum is replaced by Eriophorum virginicum and Scirpus cyperinus. Along the northwestern border Rubus nigrobaccus is making inroads upon this society. To the north of the railroad, however, the most important changes are being wrought by the development of Populus tremuloides and Quercus velutina. Young trees of the former are now scattered throughout, while the latter is present in small number. The plants of minor importance are Ilex verticillata, Viburnum lentago, Ilicioides mucronata, Amelanchier Botryapium, Euthamia graminifolia, Doellingeria umbellata, Bidens trichosperma tenuiloba, Dulichium arundinaceum, Poa flava, and Sphagnum cymbifolium.

Chokeberry society.-Aronia nigra forms the most dense and exclusive growth that occurs on the bog. Usually the substratum is somewhat lower and more subject to overflow than in the last society. It would seem from observation that this condition is in part due to the chokeberry itself. Owing to its dense growth, it protects the surface of the peat from drought and favors the processes of decay. At the same time it adds very little to the substratum in the way of débris. Where it attains its best development it is practically without undergrowth. About the borders it is mixed with Vaccinium corymbosum, Betula pumila, and Ilex verticillata. Of the smaller plants, Pteridium aquilinum penetrates to the greatest distance. Other species occurring about the borders are mentioned among the other societies.

Poplar-willow society.-About the borders of the bog, and extending to a greater or less extent into its interior, is a dense zone composed of Populus tremuloides, Salix discolor, Quercus velutina, Populus grandidentata, and Salix nigra. By far the most abundant form is the trembling aspen. The substratum varies from areas well above the water level to areas which are constantly submerged. The aspen is also the most important of the plants which are invading the shrub societies. In the relative proportion of the individual species there is the greatest variation at different places in this border zone. Of the more enduring species, Quercus velutina is the most abundant. The other species present are Salix Bebbiana, S. sericea, S. lucida, 
Prunus serotina, Quercus alba, Q. macrocarpa, Acer rubrum, Betula lutea, Amelanchier Botryapium, Viburnum pubescens, Spiraea salicifolia, S. tomentosa, Corylus americana, Sambucus pubens, Cornus candidissima, C. stolonifera, Cicuta maculata, Aster lateriflorus, Carduus altissimus, Galium asprellum, Osmunda cinnamomea, O. regalis, Ranunculus pennsylvanicus, Calamagrostis canadensis, Viola blanda, Euthamia graminifolia, Bidens frondosa, and Aster Novae-Angliae.

Sedge society. - On the northeast side of the bog is an area dominated by sedges. In the fall of the year it appears to be a uniform area of Scirpus cyperinus, but there are many other species mixed with it. The substratum is low and is mainly characterized by tussocks formed by the sedges. Throughout, occur small clumps of the willows already mentioned. The most abundant accessory species are Isnardia palustris, Calamagrostis canadensis, Carex teretiuscula, C. stipata, C. filiformis, C. fusca, C. oligosperma, C. riparia, and Aulacomnium palustris.

The future flora of this bog appears to be indicated by the rapid growth of the poplars, willows, and oaks. The few tamaracks remaining are approaching maturity and are not being reproduced. The means by which these tree species combat the shrubs is mainly by shading, while the latter in the same way interfere with the development of the tree-seedlings. The time involved in this struggle must be very great, but the ultimate outcome will be an oak forest, the intervening stages being filled in by poplar and willow growths. If, however, the decay of the peat beneath these trees brings the surface to the water level, the poplar-willow stage will be indefinitely prolonged.

\section{GENERAL CONSIDERATION OF THE BOG FLORA.}

Beside the trees mentioned in the preceding descriptions, note should be made of the occasional occurrence of the black ash, Fraxinus nigra, and swamp white oak, Quercus platanoides, in bog areas. It frequently happens, when the tamaracks are cut, that the black ash becomes abundant, as in the area one-half mile southeast of Kavanaugh Lake, where it is now associated with Ulmus americana and Acer rubrum. Another example occurs about a mile north of Chelsea in the NE. $1 / 4$ Sec. I, Sylvan Tp. Here in a small area from which the tamaracks were removed, Fraxinus nigra, Quercus platanoides, 
Fraxinus americana, F. pennsylvanica, Acer rubrum, Ostrya virginiana, Tilia americana, and Liriodendron tulipifera are associated. The undergrowth consists of Solidago patula, S. neglecta, Aster lateriflorus, Mitella diphylla, Euonymus obovatus, Viola pubescens, Agrimonia hirsuta, Cornus florida, C. candidissima, Eupatorium perfoliatum, Rosa Carolina, Viburnum Lentago, Juniperus communis, and Spiraea salicifolia. The substratum is almost entirely occupied by mosses, including Hypnum fluitans, H. Schreberi, H. Blandovii, H. roseum, Thuidium recognitum, and Climacium americanum.

On the farm of James Barton (SW. $1 / 4$ Sec. 2, Lyndon Tp.) the black ash, red maple, and American elm have replaced a former growth of tamaracks and black ash.

In a previous publication (55: p. 403) the writer called attention to the absence of a genetic relationship between the bog plants and the surrounding vegetation in southern Michigan. This was explained on the basis that the bog vegetation is a relict of former climatic conditions; that it has a genetic relationship with the conifer forest formation of northeastern North America, as shown by studies in northern Michigan and Pennsylvania, and that in this region it has been surrounded by a more southern flora whose center of distribution is the southeastern United States. Consequently no order of succession between the tamarack and the oak floras is to be expected.

When, however, bog areas are cleared or their normal development disturbed, such trees as the black ash, white ash, red maple, and elm replace the tamarack, and a definite order of succession is established.

It was also maintained that present bog habitats are continuations of similar habitats which came into existence when a colder climate prevailed than at present. More recent observations tend to confirm and strengthen this statement.

The dominance of bog and swamp plants respectively in adjoining areas is to be explained largely by the time when the areas came to support their present ground vegetation. If the habitat has existed undisturbed since the time when a colder climate prevailed, the bog plants will be dominant. If it came into existence in recent times, or has been disturbed, it will be dominated by swamp species.

(To be concluded.) 


\section{THE BOGS AND BOG FLORA OF THE HURON RIVER VALLEY.}

EDgAR NELSON TRANSEAU.

(WITH SIXTEJEN FIGURES)

[Concluded from p. 448.]

\section{The ecological characteristics of the bog flora and their causes.}

The plants occurring in the bog habitat are almost all perennials. In the case of the herbaceous vegetation, the winter is passed by means of subterranean rootstocks. The shrubs are in part evergreen and in part deciduous. The tamaracks and the two birches are deciduous, and the black spruce and pine are evergreen.

Most of the herbaceous and shrubby forms multiply abundantly by vegetative shoots of one form or another. The length of the underground stems of the shrubs is proverbial, but is best appreciated by one who has attempted to dig up one of them entire. In connection with the competition between species for space in the habitat, this is of the greatest importance. A luxuriant growth of cassandra furnishes the most:favorable situation for the development of sphagnum in this vicinity. Its profuse branching affords a framework for the upbuilding of the sphagnous layer, its shade properties do not interfere with the photosynthetic work of the moss, and it protects it from the drying effects of wind and direct insolation. Where such associations occur, the difficulties presented for the germination for most seeds, and the efficiency with which competition is combated, are evidenced by the fact that among the tree species only the tamarack, spruce, and pine are successful invaders. All of these plants send out adventitious roots from the stems and branches, and so keep pace with the upward development of the moss. The absence of poplars, willows, red maples, and elms in such undisturbed situations must be in part attributed to the completeness with which such territory is controlled by the cassandra-sphagnum association.

\section{ECOLOGICAL ANATOMY.}

Aside from the purely aquatic forms which have received much Botanical Gazette, vol. 4r.] 
Salix sericea.-Leaf: upper epidermal cells small, strongly cuticularized; mesophyll compact, palisade of two layers of long narrow cells; stomata on under surface, guard cells sunken beneath the slightly protuberant companion cells; hypoderma of five- or six-cell layers on hadrome side, and eight layers on leptome side of midvein. Root: resinous bodies present in medullary rays and cortex, the latter consisting of thick-walled cells; no mycorhiza.

Ledum groenlandicum.-Leaf: upper epidermis rugose, with scattered unicellular hairs, margins strongly revolute, cuticle present, cell walls thickened, the radial walls being broadly undulate; lower epidermis covered with a thick cuticle and a felt of long multicellular and short unicellular hairs, glandular hairs usually present near the small veins, stomata protuberant; palisade of three or four layers of broadly oblong cells; beneath vascular tissue of midvein and between the mestome bundles occur large air cells which may form lysigenic air cavities in the older leaves. Root: mycorhizal.

Larix laricina.-Leaf: bifacial, deciduous; epidermis thickwalled, slightly cuticularized, guard cells sunken beneath the companion cells; palisade tissue developed toward the dorsal surface, two layers thick showing a radial tendency, stereome reduced to a few cells beneath the leptome; two resin ducts near edges of leaf. Root: composed of mycorhiza, resinous deposits throughout, cortical tissues early destroyed by fungus. When grown in culture solutions and well aerated, normal roots with root hairs are produced.

Picea Mariana.-Plants in bogs are stunted. Leaf: epidermal cells thick-walled, cuticle present, guard cells sunk beneath the companion cells; mesophyll cells compact, of a more or less radial palisade type. Root: mycorhizal, resin deposits throughout, cortical tissues destroyed by fungus. Normal roots are developed under culture conditions.

Pinus Strobus.-Plants very much stunted in the bogs, leaves shorter and thicker. Leaf, epidermal walls so greatly thickened that scarcely a lumen remains, beneath this a hypodermal layer of thick-walled cells; mesophyll cells compact and of the usual lobate type. Root: mycorhizal, cortical tissues traversed by the fungus hyphae; resinous deposits throughout. Stem: annual rings narrow 
dan distorted, resin bodies throughout cortex and meristematic tissues of the wood.

To summarize these characteristics, it is evident (I) that epidermal and hypodermal tissues are thick-walled; (2) that for the conservation of water these are reinforced outwardly by a heavy cuticle, by coverings of wax and air containing hairs; (3) that resinous bodies are found in the roots and leaves of many of the plants; (4) that there is a general reduction in the size of the leaves, and that these are frequently revolute-margined; (5) that palisade tissue is quite uniformly developed; (6) that mycorhizal fungi are present in the roots of most of the plants; (7) that, when compared with the xero: phytes of dry sand plains $(\mathbf{2 5}, \mathbf{6})$, they show a similarity in respect to the reduction in size of the foliage, in the development of external protective coverings of the sub-aerial parts, and in the presence of palisade tissues, but are very different in the matter of root develop: ment and character of root structures.

To account for the peculiarities of the bog vegetation various theories have been brought forward. KinLman (28), in accounting for the xerophilous character of the plants of arctic swamps; which include several species common to American bogs, lays stress upon two factors: (I) the low temperature of the moist substratum, and (2) the presence of drying winds. The former influences the plants by decreasing the power of absorption, the latter increases the rate of transpiration. The plants of such habitats must therefore be protected against the loss of water by the subaerial parts.

Schimper (44, p. II) in classifying the natural habitats in which xerophytes occur mentions among others "peat bogs, because of the humous acids in the soil.", On page 18 he says:

The xerophilous character of the vegetation of peat moors has hitherto been considered an incomprehensible anomaly, and yet the rich supply of humous acids in the soil furnishes a condition for its occurrence as comprehensible as it is necessary. The presence of Scotch pine and heather on both dry sand and on wet peat is thus not more remarkable than is that of Ledum palustre, Vaccinium uliginosum, and other peat-plants on the cold dry soil in the polar zones.

Further (p. I24) the statement occurs that "on the very acid humus of moors the vegetation assumes a decidedly xerophilous character, because the humous acids impede the absorption of water by the 
roots." However, in describing the arctic vegetation (44, pp. II, 7 I5), he follows the suggestion of Kinlman, a conclusion to which he had come independently. Ganong (I6) also accepts Kinlman's explanation for the xerophilous nature of the raised-bog flora of New Brunswick.

In the study of the structural adaptations of these plants and the causes of their occurrence in bog areas, several questions arise. Are these two factors, cold substratum and acidity, efficient causes of xerophily? Do they act, in the case of the bogs of this region, with sufficient strength to cause xerophilous modifications in the plants there found, or to permit the growth of only such forms as are xerophilous?

The last question may be answered from field observations. They indicate that most low-ground plants grow quite as well on the bog substratum as on the ordinary swamp soils, and that the swamp species of this vicinity may all be found at one place or another growing on bog soils. It would seem that here the bog substratum is no more efficient as a selective agent than are the swamp soils.

The only cases which have come under my observation in southern Michigan which will throw light upon the question of the effecttiveness of the temperatures and acidity in the production of xerophilous adaptations is in the case of Picea Mariana ${ }^{7}$ and Pinus Strobus. These two plants both show reduced size of stem and leaf, in the Oxford bog, when compared with plants growing on the margin. But to what extent this may be due to sterility of the bog substratum rather than to temperature and acidity is indeterminable at this time.

\section{EXPERIMENTS.}

To answer the question of the efficiency of a cold substratum and soil acidity to produce xerophily, experiments have been in progress for approximately two years. The difficulties in the way of experimentation along these lines are numerous. The means for controlling soil temperatures in bodies of soil sufficiently large for experimentation with the larger bog plants are practically beyond the possibility of a university laboratory. When it is further realized

7 The so-called $P$. brevifolia $\mathrm{Pk}$. This form is certainly no more deserving of a distinctive name than is the bog form of the white pine. 
that the experiments should extend over a series of years in the case of the shrubby forms, the problem becomes still more complicated.
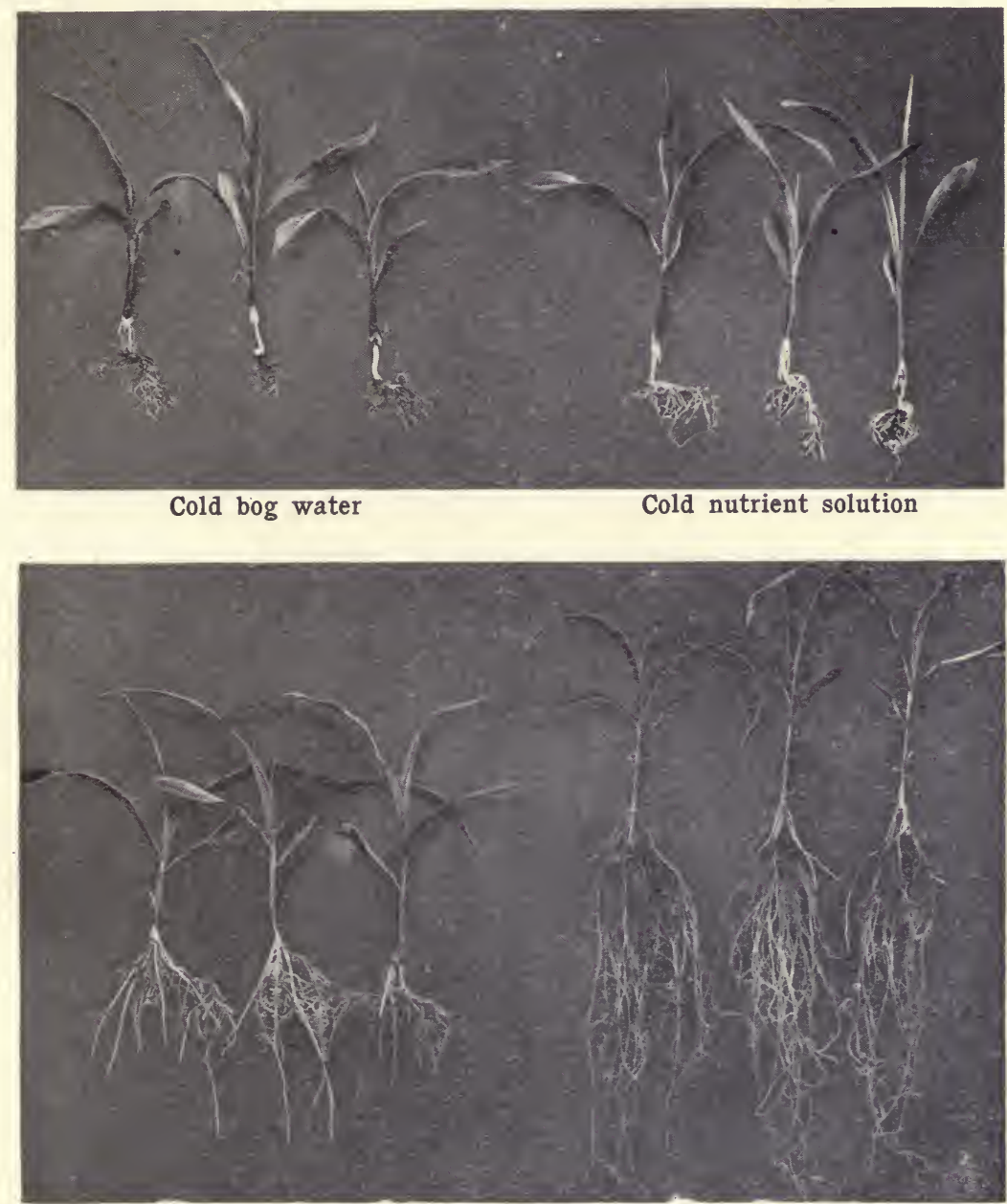

Warm nutrient solution

Warm bog water

FIG. I2.-Average plants from the several cultures of Indian corn. From photographs.

In order to test the relative effects of humous acids (of the concentration found in the bogs of this vicinity) and low substratum temperatures, experiments were made in the form of water cultures 
and with a peat substratum. All of the bog water used was brought to the plant house from the First Sister Lake. The acidity of the water varied from .0005 to .0023 normal acid, as measured by $n /$ Io० $\mathrm{KOH}$ solution.

WATER CULTURES.-(I) The plants were grown in four-liter battery jars covered with a plaster of Paris plate, having five one-inch openings for the passage of the plants and one of smaller size for a thermometer. Four such jars were employed in each experiment, two containing a 0.2 per cent. Knop's solution, and the others bog water. One of each was further maintained at a lower temperature. The cooling was accomplished by passing tap water through $\mathrm{I}_{5}$ feet of quarter-inch $\left(4.5^{\mathrm{m}} \times 7^{\mathrm{mm}}\right)$ glass tubing, arranged in a coil within the jar, somewhat below the surface of the liquid. The sides and bottoms of the jars were covered with black paper, and those which were to be cooled were further surrounded by white paper and sphagnum. Daily readings of the temperatures of the air, warm-water solutions and cold-water solutions during the warmest period of the day were recorded. In this way the maximum differences between substrata and air were obtained. As these temperatures were not constant they exaggerate, to a slight degree, the average differences in temperature. Thus, four conditions were obtained which are comparable: (I) warm nutrient solution (temperature approximating that of the air of the plant-house), (2) warm bog solution, (3) cold nutrient solution, and (4) cold bog solution.

Fig. I2 shows the results of one of these experiments with corn. The photograph was taken eighteen days after the experiment was started. When the cultures were set up, the plumule had developed to a length of 2 inches $\left(5^{\mathrm{cm}}\right)$. The air temperatures during the period of experimentation averaged $18.8^{\circ} \mathrm{C}$., that of the warm cultures $18.7^{\circ}$ C., and of the cold cultures $10.8^{\circ} \mathrm{C}$.

It is to be noted that under these conditions the best growth of the leaves and roots occurred in the bog water. But a reduction of $8^{\circ}$ in the substratum temperatures caused a diminution in the development of both leaves and roots; the plants in the nutrient solution and the bog water being equally affected. When all of the plants had developed five leaves, it was noted that in the case of the cold cultures the two lower leaves had withered. This experiment was 
repeated with corn, white lupine, and bean under similar conditions, with similar results. The greater development of roots in the case of the warm bog water may be due to the presence of a poison in very minute quantities; but this I have been unable to prove.

(2) A third culture was then made in which five plants of corn were grown in each of the four water culture conditions, and in addition in four similar conditions, using a mixture of sphagnum and peat for the substratum. Wooden boxes 2 feet long, I foot wide and a half foot deep $\left(60 \times 30 \times{ }_{5} 5^{\mathrm{cm}}\right)$ were constructed, and two were lined with galvanized iron. The bottoms of the unlined ones were perforated so as to allow of easy drainage. The lined boxes served for the undrained conditions. Further, in one of the drained and in one of the undrained boxes, 40 feet $\left(\mathrm{I}^{\mathrm{m}}\right)$ of glass tubing, bent into coils, the joints being connected by rubber tubing, were arranged so that a constant flow of cold water, for lowering the temperature, could be maintained. The water level in the undrained bog substratum was kept just below the surface. The water was obtained from the bog at First Sister Lake, but occasionally all were watered with distilled water. The amount added to each box was practically the same. In order to keep the solutions in the water culture jars at the same acidity as in the undrained boxes, the water was siphoned off and transferred once a week. Care was taken in this transfer to aerate the water in the boxes as little as possible, while that of the jars was aerated at irregular intervals by means of a bulb. There were thus produced eight conditions, in which it was possible to test the effect of the acidity of the bog water, of aeration (drainage) of the substratum, and of low temperatures. As a result, it was found that the growth of roots and leaves was best in the warm bog water, in the warm nutrient solution, and in the drained warm peat substratum. Reduction in size of both roots and leaves occurred in the cold bog and nutrient solutions, and in the drained cold and undrained warm and cold peat substrata. But the plants in the undrained cold peat showed the most marked reduction in size. The conclusion was reached (I) that humous acids (acidity varying from .0005 to .0023 normal acid) have no effect upon corn in the matter of leaf and root development; (2) that low temperature and lack of aeration of the substratum both cause reduction in size; 
and (3) that when low temperature is combined with poor aeration the effect is very marked.

This experiment was repeated with peas, and the same result was obtained, although the effects were not so marked (fig. I3). The roots in the undrained substrata were killed when they attained a depth of a half inch ( $12^{\mathrm{mm}}$ ) below the surface:

(3) In order to test the effects of drainage and of low temperature on bog species, another set of cultures in peat-sphagnum substrata was made. The apparatus used consisted of two flower-pots and two glass dishes aproximately a foot in diameter and three inches

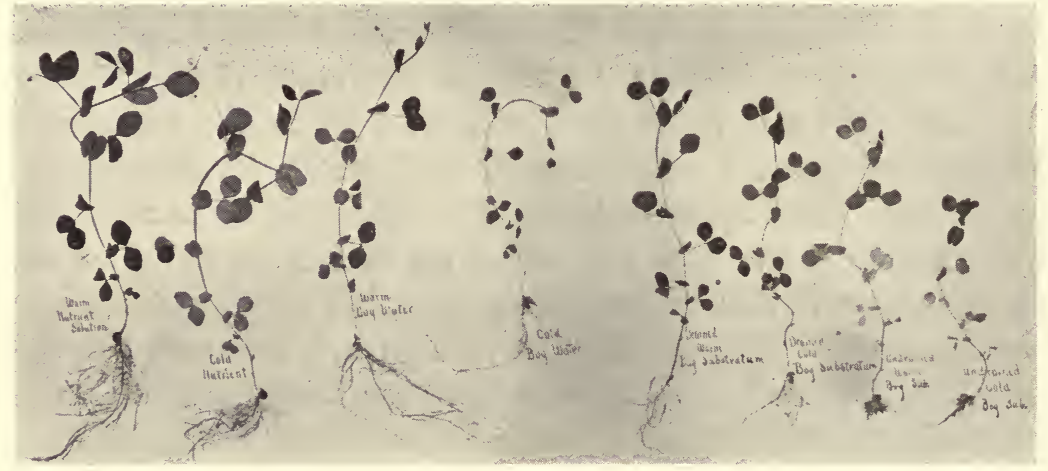

FIG. I3.-Effect of the several conditions upon the development of pea seedlings. All are average specimens. From photographs.

deep $\left(30 \times 7.5^{\mathrm{cm}}\right)$. A flower-pot and a glass dish were kept cool by passing cold water through fifteen feet of glass tubing arranged in coils, as in previous experiments. Three species were tested in these conditions: two-year-old Larix laricina, Rumex acetosella, and Prunella vulgaris. The first cultures were made in the spring of I903 with the Rumex and Prunella. The air temperature averaged about eighteen degrees. The cold substratum was maintained about ten degrees lower. In the case of Rumex it was found that the largest leaves were produced in the drained peat-sphagnum substratum. Lack of drainage and low temperature both caused a reduction in leaf area, and when combined produced leaves which were less than half as large as those of the drained warm substratum.

The Prunella under the same conditions showed the same results. 


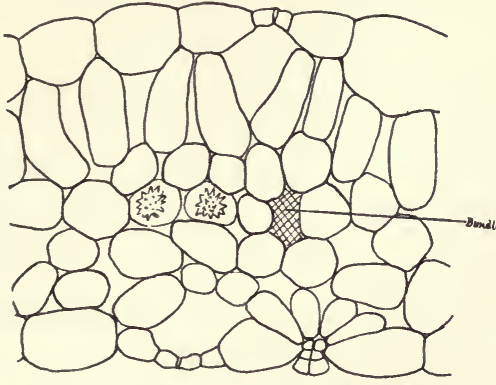

A. Drained warm bog substratum

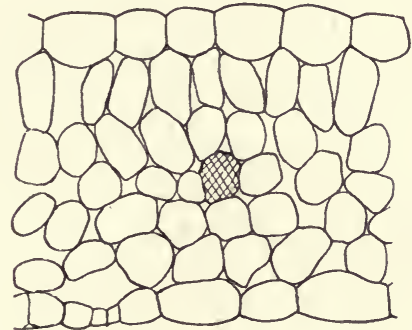

C. Undrained warm bog substratum

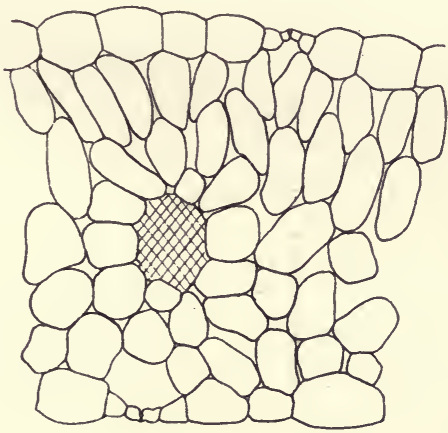

E. Dry sand

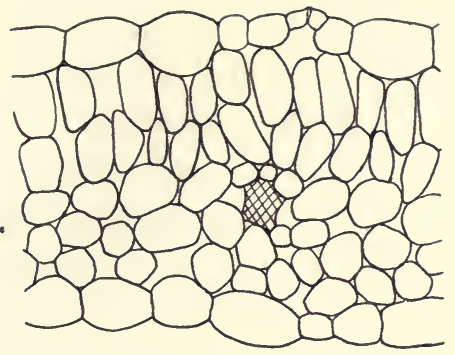

B. Drained cold bog substratum

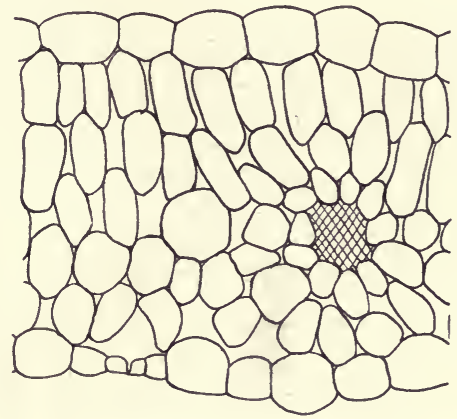

D. Undrained cold bog substratum

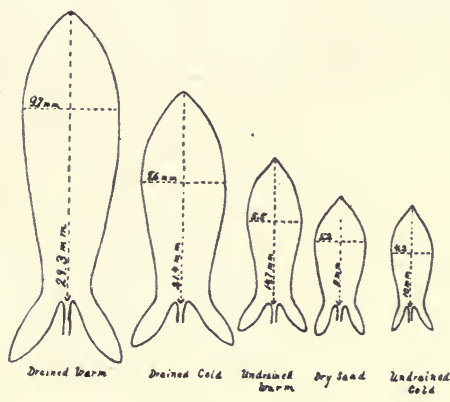

F.

Fig. I4.- $A, B, C, D, E$, camera drawings of leaf sections resulting from cultures in the five conditions named. $\times \mathrm{I}_{35} . F$, diagrams showing average length and breadth of leaves. 
Fifteen plants were grown in each condition. At the end of the experiment each had produced six to eight mature leaves. The leaves were measured as to length and breadth. An index was obtained by multiplying these two numbers together and averaging for each culture. Following are the indexes of leaf area thus derived: drained warm substratum I268.3, drained cold 682.6, undrained warm $5^{\mathrm{I} 8.5}$, undrained cold $42 \mathrm{I} .8$.

In the spring of 1904 the experiment with Rumex was repeated. The results correspond with those of the preceding year. The structure of the leaves, resulting in the several cultures, was investigated, and found to show marked variations (56). Fig. I4 represents the cross-sections and average leaf areas produced (seventy-five leaves being measured in each case). When grown on a warm drained substratum, the leaves are large, and the cells are exceedingly loose and turgid. The epidermis is composed of large thin-walled cells, having a thin cuticle outside. The mesophyll consists of a single layer of palisade and three layers of spongy tissue. No resin bodies are present. The plants grown in the undrained substratum, whose temperature was reduced about $8^{\circ} \mathrm{C}$. below that of the air, show marked xerophilous characters. The leaf is reduced in area, increased in relative thickness, and the margins become revolute; the epidermal cells are smaller and outwardly thick-walled; a wellmarked cuticle is present; the mesophyll is very compact and made up of two or three layers of well-developed palisade cells and three layers of spongy tissue; and in the epidermal cells and those adjacent to the bundles there are marked accumulations of resinous bodies.

For the purpose of comparison, a corresponding set of plants were grown on sand kept just sufficiently moist to allow the plants to live. As will be seen in fig. I4, the xerophily is not more marked than that of the undrained cold bog substratum. Fig. I5 shows the relative appearance of the plants produced by the different conditions.

In the case of the plants grown in the undrained warm and the drained cold substrata, these same effects were noticeable, but to a less marked degree. That, in the case of the undrained cultures, these effects are not due to the acidity of the bog water is shown by 
the fact that plants grown in bog-water cultures develop normally.

The light conditions in the several cultures were the same, direct sunlight being avoided by a cloth screen. It is evident that in this case there is no response to strong light in the development of the palisade tissue (49). It would seem rather to be a response called forth by a reduced transpiration current $(44$, p. 7$)$. As to function, it may aid in the transfer of food materials as suggested by HABERLANDT (20, p. 260).

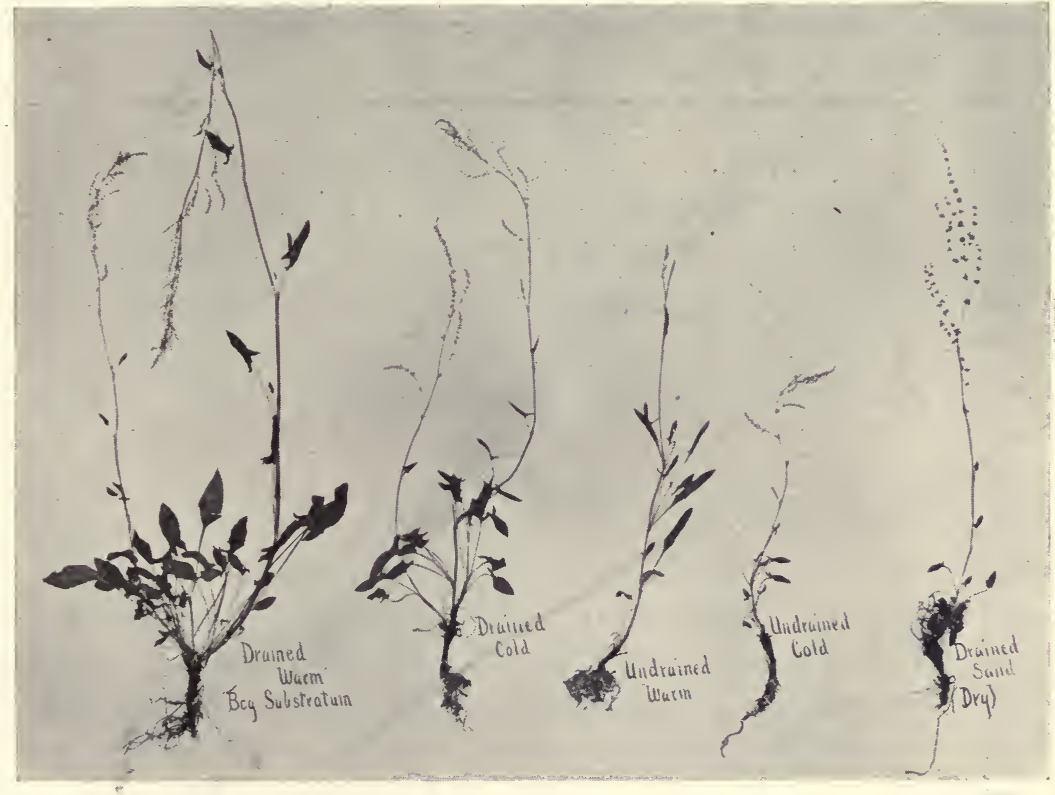

FIG. 15.-Average plants showing effect of surrounding conditions. From photographs.

This plant proved to be: the most plastic of all of the species used in the experimentation, and was the only one which showed marked variation in the internal structures. Ecologically the results indicate (I) that an undrained peat substratum may cause xerophilous structures, but that the effect is to be correlated with lack of aeration of the substratum rather than with the acidity; (2) that the same effect may be induced by lowering the substratum temperature (the air temperature remaining the same), and thus impeding the rate of 
root growth and absorption; (3) that a cold undrained bog substratum is analogous to a dry warm soil in that both produce physiological drought; (4) that resin bodies, which are characteristic of the bog plants, may be produced by this environment in a plant which under favorable conditions is without them.
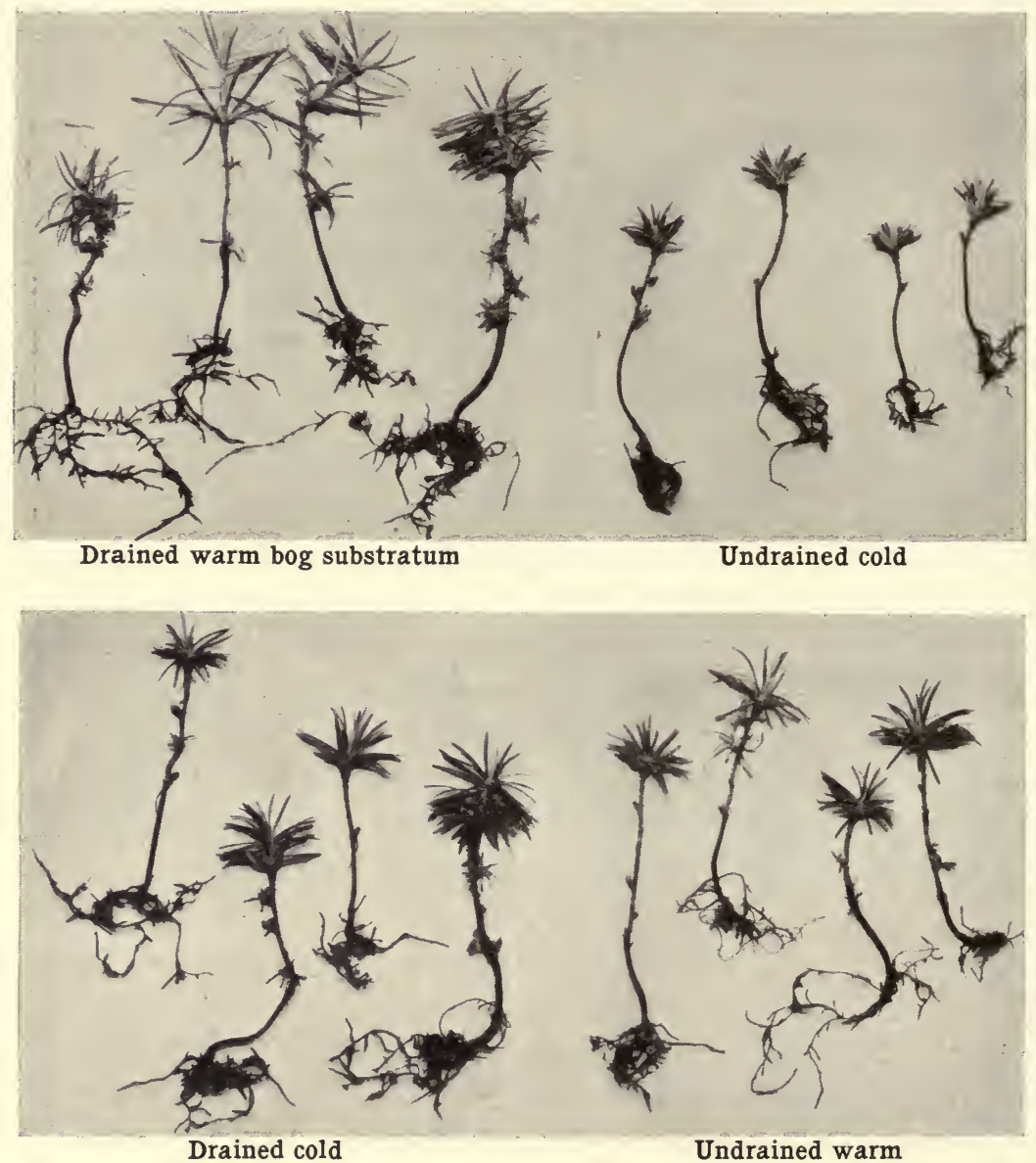

FIG. I6.--Relative effects of drainage and reduced substratum temperature, on Larix. From photographs.

The seedling tamaracks, ten of which were cultivated in each of the four conditions just described for the Rumex, also showed considerable variation. Their relative development at the end of forty- 
four days is shown in fig. I6. The leaves of the drained warm substratum have an average length of $\mathrm{I} 2.6^{\mathrm{mm}}$, of the drained cold $\mathrm{IO} \mathrm{mm}$, of the undrained warm II.4 $\mathrm{mm}$, and of the undrained cold $6.3 \mathrm{~mm}$. Internally, the leaves show a reduction in the intercellular spaces and in the size of the cells in the case of the plants grown on the undrained cold substratum, when compared with those of the warm drained condition.

(4) In another series of experiments with plants of Larix four to five years old practically the same results were obtained. There were the greatest number and length of leaves and branches produced in the case of the drained warm substratum. The smallest and shortest leaves and branches were produced by the undrained cold substratum.

Experiments with Ledum Groenlandicum, Chamaedaphne calyculata, Andromeda Polifolia, Betula pumila, and Oxycoccus macrocarpus have failed to produce satisfactory results. This is believed to be due to the shortness of the time under which they were under cultivation. The plants were brought from the bogs in the late autumn and placed in cold frames over the winter. About the beginning of March they were brought into the -greenhouse, and after a few days planted in the warm and cold, drained and undrained boxes, previously described. They have grown vigorously, but the differences noticeable may not be correlated with the four conditions. The cranberry has shown the greatest amount of plasticity, but this could not in all cases be correlated with the environment. If these plants can be kept under known conditions for two or more years, it is probable that they will yield valuable results.

(5) In order to test the effect of mineral soils, and the ability to withstand the presence of large quantities of calcium and magnesium, specimens of andromeda, cassandra, and cranberry were grown in sandy loam and sand. They were watered daily with tap water. The cultures were started in the autumn of 1902, and produced vigorous vegetative shoots during the summer of I $_{903}$. They failed to bloom, however, and although they are growing well at this time (June I904), they have again failed to bloom. This may be in part due to the warm plant-house conditions. The experiment was originally started to observe the changes in the roots, and in so far 
have been of value. In a sphagnum substratum all three of the plants produced hairlike roots which attain a length of $5^{-7^{\mathrm{cm}}}$. The roots are commonly several times branched, very little difference in thickness being shown by the several branches. When grown in sand the roots are still slender, but the frequency of branching is enormously increased. Usually the branching occurs just back of the growing tip. The older root ceases growth as the lateral root develops. The branch continues for $2-3{ }^{\mathrm{mm}}$, and it also stops growth with the formation of a second lateral root. The result of this process is a zigzag root showing root branches which have been successively the main root tip. Occasionally several lateral roots develop and the main axis is divided.

(6) The statement that waters containing lime and other mineral salts are unfavorable to the growth of sphagnum has gained wide circulation in ecological literature. Because of the great abundance of lime and magnesia in the waters of this vicinity; I was led to test this fact by growing the sphagnum in tap water and solutions of $\mathrm{CaCO}_{3}$. In one experiment the water in a battery jar was saturated with $\mathrm{CO}_{2}, \mathrm{CaCO}_{3}$ was added in excess, and the $\mathrm{CO}_{2}$ was again allowed to pass through the water for thirty minutes. In this solution sphagnum was placed, and it has been growing vigorously for three months, although watered daily with water containing over roo parts of $\mathrm{CaCO}_{3}$ to the million. Some of the sphagnum cultures have been running for ten months, and show no signs of deterioration. Whether the sphagnum of this vicinity has become accustomed to the presence of lime, owing to the nature of the soil waters, or whether sphagnum is generally able to withstand such conditions, remains to be proved. Since the above experiments were performed, I have found an account of somewhat similar experiments by WEBER (58), the results of which are the same. It would seem, therefore, that the presence or absence of sphagnum is not to be correlated with the presence or absence of lime.

(7) Among the plants growing in the bogs of this vicinity the following have been found to possess mycorhiza: Larix laricina, Pinus Strobus, Picea Mariana, Betula lutea, Betula pumila, Oxycoccus macrocarpus, O. Oxycoccus, Chiogenes hispidula, Vaccinium corymbosum; Ledum Groenlandicum, Populus tremuloides. 
In order to get at the conditions which favor or cause the development of mycorhiza, cultures of Larix were made in loose sphagnum, sand, undrained sphagnum, etc. The roots in the many other cultures previously noted were also carefully watched. It has been found without exception that where the plants were grown under properly aerated soil conditions, normal roots developed in place of the mycorhiza. That the acidity of the bog water has nothing to do with the production of mycorhiza is shown by the fact that in water cultures of the same acidity as the solution in the undrained peat, the plants develop normal roots. In the case of roots developed in loose sphagnum, sand, and moist air, an abundance of root hairs were produced. The normal roots in Larix have a diameter about three times that of the mycorhiza, so that when they begin to develop they appear like white pendants from the dark brown mycorhiza. That mychoriza will not develop in a well-aerated substratum was further tested by the following experiment: Two $30^{\mathrm{cm}}$ test tubes were set upright, and $8^{\mathrm{cm}}$ of glass beads were poured into the bottom of each. Into one a glass tube, at whose end were several small openings, was passed to the bottom. The upper part of the tube was connected with a gasometer. Upon this foundation of beads, three plants of Larix were planted in a $5^{\mathrm{cm}}$ layer of peat in each tube. The water level in the two tubes was kept just at the surface, bog water being used throughout. Air was then forced from the gasometer to the bottom of the one tube and allowed to pass slowly through the beads and peat. When the experiment was started, all of the plants possessed only mycorhiza. In the course of a week the aerated plants began to develop normal roots. The experiment was continued for six weeks. The unaerated plants developed only mycorhiza, while those which were aerated developed normal roots. ${ }^{8}$ The growth of mycorhiza is exceedingly slow, and the fungus grows with the root. The development of the above ground parts corresponds to the root development. The plants which produce normal roots have longer shoots, and longer, thicker leaves.

It seems evident, in the case of Larix at least, that (I) the mycorhizas develop only in poorly aerated substrata; (2) their growth is

${ }^{8}$ In the case of a number of the plants of Larix grown in the undrained peat in previous experiments, one or two normal roots were developed just at the surface of the substratum. 
exceedingly slow, the fungus developing along with the root; (3) the acidity of the substratum is not a factor in their development; (4) in a naturally well-aerated soil or in an artifically aerated substratum normal roots develop; (5) when the roots are not surrounded by water, root hairs develop abundantly. Mycorhiza therefore appears to be an abnormal root condition. Whether the fungus is of advantage to the root under these poorly aerated conditions cannot as yet be stated.

(8) In order to determine whether the zone of tamaracks follows the shrub zone because of the occasional submergence of the sedge zone, the following test was made: Ten Larix seedlings averaging $7^{\mathrm{cm}}$ in height were placed in a crystallizing dish with the roots imbedded in $2^{\mathrm{cm}}$ of sphagnum. Over this a layer of bog water $4^{\mathrm{cm}}$ in depth was maintained for six weeks. The plants grew quite as well as those in a peat substratum. Stem and root submergence is therefore not a factor in preventing the growth of seedlings tamarack in the sedge zone. The liability to submergence in the bogs I have studied would not extend over nearly so long a period of time.

\section{Summary.}

The Huron River basin shows three well-marked physiographic divisions which differ in forest covering and the possibilities for bog development. These are (I) the region of the Saginaw-Erie interlobate moraine; (2) the Erie morainic belt; and (3) the lake plain.

In discussing the meteorological conditions of a region as affecting the flora, attention is called to the fact that the significance of the data is not apparent unless the temperature and rainfall phenomena are compared with those of the optimum region of dispersal of the plant societies involved. In the case of the bog plant societies the temperature of the region under discussion averages several degrees higher during the summer months than the eastern maritime provinces of Canada (the optimum region of dispersal for the bog plants), while the rainfall during the same period averages about threefourths as much. This is believed to account for the general difference in character and development of bog societies in the two regions.

Bog and lake basins are here associated with deposits of glacial drift. The most frequent causes of these basins are (I) the melt- 
ing of stagnant bodies of ice in old glacial drainage channels after their abandonment; (2) the differential settling of fluvio-glacial deposits; and (3) unequal deposition of glacial material in moraines and till plains.

Marl and peat deposits are commonly associated. The former are of interest in so far as they aid in the filling of the lake basins. Both are formed through plant agencies.

Peat deposits may be classified under two general heads: (I) those connected with glaciation, and (2) those associated with coastal plain phenomena. In North America the bulk of the deposits come under the first head. Their geographic distribution approximates that of the Pleistocene glaciers. Near the southern border the peat areas are scattered, but they become more nearly continuous and more independent of depressions as we go northward. The same effect is brought about in mountainous regions by increased altitude. In the tundra, peat accumulates because of the low temperature and in spite of the scant vegetation. In temperate regions a vigorous vegetation and areas of stagnant water render peat accumulation possible. In the southern coastal plain swamps, peat is formed in stagnant water because of the luxuriant vegetation and in spite of the high temperature.

During peat formation two processes are involved: (I) eremacausis and (2) putrefaction. The former is essentially an oxidizing process, brought about in the presence of air by certain fungi and bacteria. Its products are of direct value as food materials for plants. Putrefaction is carried on in the absence of oxygen and is essentially reduction; the organisms involved are anaerobic bacteria, and the products are of no value to the higher plants as food materials. The accumulation of peat depends upon the scarcity of oxygen below the water level, the acidity of the ground water, and the occurrence of low temperatures.

Peat varies in color beneath the various plant societies, being light brown in the youngest (bog sedge) and dark brown in the oldest, the darkest and most thoroughly decayed form being known as "muck." As disintregration proceeds it brings about a decrease in water capacity, a decrease in volatile combustible matter, and an increase in the amount of ash. 
The bog as a habitat for plants differs widely from the other plant habitats of the region in that its substratum has been built by forerunners of the present vegetation. Owing to the influence of the wind in the production of waves, the bogs are largely wanting on the eastern shores of lakes, and in the case of basins which have been almost completely filled with peat, the open water lies toward the eastern margin.

It is well known that bog areas are more liable to late spring frosts than adjoining uplands. This is due to the topography as it affects air drainage, and to the low conductivity of the substratum covering. Under natural conditions it has been found that the areas of cassandra and tamarack dominance are more exposed to late frosts than other societies.

Observations in bog areas show that the soil temperatures beneath the several plant societies differ markedly in range. The records indicate that the areas of bog sedges have temperatures corresponding closely with those of the upland and approximating those of the atmosphere. The willow-sedge (swamp) and maple-poplar areas have slightly lower temperatures during early spring. When the trees leaf out, however, the shade produced causes the maple-poplar area to have the lowest temperatures recorded. The bog shrub and tamarack societies show the lowest average temperature throughout the spring months.

Low soil temperatures retard chemical action, diffusion, solution, and osmosis, and render the substratum unsuited to soil bacteria. When coincident with higher air temperatures, plants having a low transpiration ratio are favored in the competition between species.

In so far as southern Michigan is concerned, the substratum temperatures prevailing in bog areas do not seem to be adequate to account for the presence or absence of bog plants or their xerophilous structures. Experiments suggest, however, that farther north this factor is of prime importance.

In texture the bog substratum shows every gradation from the coarse fibrous peat of the bog-sedge zone to the black powdery muck of cleared land. Bog soils in general do not afford as good a foothold for trees as do the mineral soils.

Peat is very resistant to the diffusion of mineral salts, hence bog 
areas have a very different soil solution from that of the mineral soils adjoining. The high water capacity of peat is detrimental to plants, in so far as it prevents proper aeration of the substratum. Bog waters have no higher osmotic pressure than ordinary soil waters.

The absence of sphagnum from local bogs cannot be explained by the presence of calcium salts, as shown by observation, chemical analyses, and experiments.

The acidity of local bog water varies from .000I5 to .00258 normal acid. The lowest values are found in areas covered by bog sedges and swamp plants, and they are approximately the same. The highest occur under the tamaracks. The variations in acidity are related inversely to the temperature. As shown by experiment, this is because of increased oxidation at the higher temperatures. It is suggested that we should find increased acidity as we go north. There is no apparent relation between color and acidity, except that light colored waters usually show slight acidity. The acid nature of the soil solution is a factor in the competition between different species for the occupancy of bog areas.

Bog soils are notably deficient in potassium and available nitrogen. Nitrifying bacteria are prevented from carrying on their normal activities by the acidity of the soil solution, by the lack of oxygen, and by the lower temperature of the substratum.

With few exceptions bog plants are light-demanding forms; hence, in their competition with one another, size and shading ability are prime factors.

That the conditions in the Huron valley are at present not as favorable to the bog plants as to the swamp plants, is shown wherever the two societies come into competition. This fact must be contrasted with the situation in the optimum region of the distribution of bog plants, where the opposite relation has been shown to exist.

An examination of all the physical and chemical data now available fails to account for the differences in flora of bog and swamp areas in this region. The most important factor is believed to be their physiographic history. Where the habitat dates back to Pleistocene times and has remained undisturbed, we find today the bog flora. Where the habitat is of recent origin or has been recently dis- 
turbed, we find the swamp flora, or mixtures of swamp and bog species.

The nature of the bog plant societies of the Huron basin is shown by the description of several local bogs, selected to show both the local bog flora and the variation in societies, and arranged to present the genetic changes in a bog flora as a basin filled by peat accumulation. It is shown that during the early stages of bog development, bog sedge, bog shrub, and conifer societies follow each other in the invasion of the basin. These several societies may vary considerably in composition, but they are closely related and show every gradation in a definite order of succession. The bog conifers, however, show no relationship to the surrounding broad-leaved forests of the upland. On the other hand, where clearing has occurred, swamp sedges, swamp shrubs, and swamp trees gain the ascendency, and these not only show an order of succession among themselves, but are genetically related to the broad-leaved trees of the region. The bog societies are part of the northeastern conifer forest formation, while the swamp societies are related to the southeastern broad-leaved forests.

An anatomical study of the bog plants shows that epidermal and hypodermal tissues are thick-walled, that a heavy cuticle is present, frequently supplemented by wax and hairs. Resinous bodies are to be found in the roots and leaves of many of the plants. The leaves are usually small and revolute-margined. Palisade tissue makes up a large part of the mesophyll. Mycorhizas are present in most of the plants. Bog plants resemble the plants of dry sand plains in reduction of foliage area, in development of protective coverings for above-ground parts, and in palisade tissues, but differ from the latter in the matter of root development and root structures.

Experiments indicate that the local bog water itself has no tendency toward the production of xerophilous modifications. Low soil temperatures and lack of soil aeration, however, cause a reduction in the development of the several plant organs. When these two factors are combined, the effect is very marked.

Experiments with Rumex acetosella are of especial interest in that nearly all of the characteristics of bog plants may be developed either by lowering the soil temperature, as compared with the air temperature, by preventing proper soil aeration, or by growing in 
dry sand. Palisade tissue was developed in the leaves of these plants in diffuse light, and it is shown that palisade tissue is to be correlated with physiological drought. An analogy between the bog habitat and the dry sand habitat is established.

Experiments with Larix indicate that mycorhizas develop only in poorly aerated substrata; their growth is exceedingly slow; the acidity of the substratum is not a factor in their development; a naturally or artificially aerated substratum favors the development of normal roots, and these roots when not surrounded by water develop root hairs abundantly. Larix seedlings can withstand prolonged submergence. When exposed to low substratum temperatures and poorly aerated soil conditions, Larix produces more xerophilous leaves.

Further field work on the bog plant societies needs to be carried on in the region extending from Winnipeg to New Brunswick. Data on the soil and air temperatures, the acidity, the chemical composition of the soil solution, and the plants associated in bog areas throughout this region will go far toward solving the problems of the distribution of bog plants. Experimentation on the production of xerophilous structures by bog conditions should be continued on a larger scale than is possible in the ordinary university plant-house.

To Professor V. M. Spalding and Professor F. C. Newcombe, of the University of Michigan, under whose direction this work was planned and carried out, I desire to express my sincere thanks both for helpful suggestions and the facilities of the institution which were freely placed at my disposal. Many thanks are also due Profėssor I. C. Russell for criticism of the physiographic part of this paper. I wish to acknowledge the kindness of Mr. Frank LEVERETT, of the U. S. Geological Survey, whose intimate knowledge of the glacial geology of this region has been most helpful to me in the prosecution of my own field work. To Mrs. N. L. BRitTon I am indebted for the determination of the mosses. Finally I take this opportunity to express my appreciation of my friend and former instructor, Dr. H. C. Cowles, to whose writings and lectures I owe my interest in ecological botany.

UNIVERSITY OF Michigan. 


\section{BIBLIOGRAPHY.}

I. BAIley, V., Tamarack swamps as boreal islands. Science, N. S. 3:250. I 896.

2. Barbour, E. H., Report State Geologist of Nebraska I:193-I98. 1903.

3. Bezz, J. O., Influence of temperature on the rate of nitrification. Ann. Rept. Wis. Agric. Exp. Sta. 18:224. I90I.

4. Blanck, E., On the diffusion of water in humus soils. Landw. Vers. Sta. 58:145. 1903. Review, Exper. Sta. Rec. 14:848. I903.

5. Blatchley, W. S. and Ashley, G. H., The lakes of northern Indiana and their associated marl deposits. 25th Ann. Rept. Dept. Geol., Indiana. I9OI.

6. Britton, W. E., Vegetation of the North Haven sand plains. Bull. Torr. Bot. Club 30:571. 1903.

7. Coulter, S. M., An ecological comparison of some typical swamp areas. Rept. Mo. Bot. Gard. I 5:40. I904.

8. Cowles, H. C., Physiographic ecology of Chicago and vicinity. Вот. Gaz. 3 I : I45. I90I.

9. Davis, C. A., A contribution to the natural history of marl. Jour. Geol. $8: 485$. 1900 .

I0. ——, A second contribution, etc. Jour. Geol. 9:49I. I90I.

II. Davis W. M., Elementary meteorology. Ginn \& Co. I898. .

I2. DeCoriolis, E. G., Investigation of the composition of soils rich in vegetable matter. 29th Ann. Rept. Ont. Agric. Coll. I903.

I3. Dryer, C. R., Lessons in physical geography. Amer. Book Co. Igor.

14. Dumont, M. J., Les causes d'infécondité des sols tourbeux. Compt. Rend. Acad. Sci. Paris 133:1243. I901.

15. FRÜH, J. J., Ueber Torf und Dopplerit. Zürich. I883.

I6. Ganong, W. F., Raised peat bogs in the province of New Brunswick. Proc. Roy. Soc. Can. II. $3^{4}:$ I31. I897.

17. ——, Raised peat bogs in New Brunswick. Bot. Gaz. I6: 123. I89I.

I8. - - The vegetation of the Bay of Fundy salt and diked marshes. Вот. GAz. 36: I6I. I903.

I9. Gilbert, G. K., Glaciers and glaciation. Harriman Alaska Expedition 3: I-231. Review, Science, N. S. 19:783. I904.

20. Haberlandt, G., Physiologische Pflanzenanatomie. Leipzig, 1896.

2I. Hale, D. J., Marl and its application to the manufacture of Portland cement. Geol. Survey of Mich. 83. I903.

22. Hopkins, C. G., Soil treatment for peaty swamp lands. Bull, 93, Ill. Agric. Exper. Sta. I904.

23. Huston, H. A., and Bryan, A. H., Swamp muck. Rept. Ind. Agric. Exper. Sta. I900: 73 .

24. Jutien, A. A., On the geological action of humus acids. Proc. A. A. A. S. 28:3II. I879. 
25. Kearney, T. H., The plant covering of Ocracoke island. Contrib. U. S. Nat. Herb. 5:26r. I900.

26. - Report on a botanical survey of the Dismal Swamp region. Contrib. U. S. Nat. Herb. 5:32I-550. I90I.

27. Kedzie, R. C., Michigan soils. Bull. 99, Mich. Agric. Exper. Sta. I893.

28. Krhlman, A. O., Pflanzenbiologische Studien aus russisch Lappland. Act. Soc. pro Fauna et Flora Fennica 6:II3. I89o.

29. Kıng, F. H., The soil. Macmillan Co. I895.

30. - and JefFery, J. A., The character and treatment of swamp or humus soil. Bull. 80, Wis. Agric. Exper. Sta. I900.

31. Lane, A. C., Lower Michigan mineral waters. Water Supply and Irrigation Papers U. S. Geol. Survey, No. 3I. I899.

32. Leverett, F., Glacial formations and drainage features of the Erie and Ohio basins. Mon. 4I, U. S. Geol. Surv. I902.

33. Livingston, B. E., Physical properties of bog water. Bот. Gaz. 37:383 I904.

34. Lucas, F. A., Animals before man in North America. Appletons, New York. I902.

35. MacMillan, C., On the formation of circular muskeag in tamarack swamps. Bull. Torr. Bot. Club 23:500. I896.

36. Mayer, A., Agriculturchemie 2:69. Heidelberg. I875.

37. Morgan, L. H., The American beaver and his works. Lippincott \& Co. I868.

38. Mulder, G. J., Die chemie der Ackerkrume, pp. 308-364. Berlin I86I

39. Ramann, E., Forstliche Bodenkunde und Standortslehre. Berlin. I893.

40. Ries, H., Uses of peat and its occurrence in New York. 2ist Rept. N. Y. State Greologist. I90I. r 55 .

4I. Rowlee, W. W., Swamps of Oswego county. Amer. Nat. 31:690. I897.

42. Russeli, I. C., The Portland cement industry in Michigan. Ann. Rept. U. S. Geol. Surv. 22:635. I901.

43. - - Glaciers of North America. Ginn \& Co. Igor.

44. Schimper, A. F. W., Pflanzengeographie auf physiologischer Grundlage. Gustav Fischer, Jena. I898.

45. Seeley, D. A., The temperature of the soil and surface of the ground. Monthly Weather Rev. 29:501. I90I.

46. Shaler, N. S., The freshwater morasses of the United States. Ann. Rept. U. S. Geol. Surv. I0:261. I890.

47. Sitensky, F., Ueber die Torfmoore Böhmens. Arch. der Naturw. Landesdurchforschung von Böhmen $6^{\mathrm{x}}: 228$. I891.

48. Snyder, H., Report on composition of muskeag soils. Bull. 8I, Minn. Agric. Exper. Sta. I903.

49. Stahl, E., Ueber den Einfluss des sonnigen oder schattigen Standortes auf die Ausbildung der Laubblätter. Jenaische Zeitschrift für Naturw. г883 : 6 . 
50. Stockbridge, H. E., Rocks and soils. J. Wiley \& Sons, New York. I895.

5I. Stupart, R. F., The climate of Canada. Scot. Geog. Mag. I4:73. I898.

52. TARr, R. S., The physical geography of New York state. Macmillan Co. New York. I902.

53. TAYlor, F. B., Correlation of Erie-Huron beaches with outlets and moraines in southern Michigan. Bull. Geol. Soc. Amer: 8:31. I897.

54. Todd, J. E., The moraines of southeastern South Dakota and their attendant deposits. Bull. I58, U. S. Geol. Surv. I899.

55. Transeau, E. N., On the geographic distribution and ecological relations of the bog plant societies of northern North America. Bот. Gaz. 36: 40I. I903.

56. - The development of palisade tissue and resinous deposits in leaves. Science, N. S. I9:866. I904.

57. Wagner, G., Observations on Platygonus compressus LeConte. Journal Geol. II:777. I903.

58. Weber, C. A., Ueber die Moore, u. s. w. Jahresbericht der Männer vom Morgenstern 3: I-23. Review, Bot. Cent. 88: I 7.

59. Weld, L. H., A peat bog and morainal lake. Bot. Gaz. 37:39. I904.

6o. Wheeler, H. J., Results of many experiments on "acid upland soils" are to be found in the 6th, Ioth, and I2th Ann. Rept. of the R. I. Agric. Exper. Sta. I893, I897, and I899. Also see bulletins no. 46, 47, 49, 66, 69, 7г. 90 and 95 of the same station.

6r. Wollny, E., Die Zersetzung der organischen stoffe. Heidelberg. I897. 


Reprinted from the Boranical Gazette, 36:40I-420, December 1903

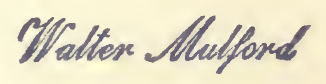

ON THE GEOGRAPHIC DISTRIBUTION AND ECOLOGICAL RELATIONS OF THE BOG PLANT SOCIETIES OF NORTH AMERICA

\author{
EDGAR N. TRANSEAU \\ FERRY FELLOW IN BOTANY, UNIVERSITY OF MICHIGAN
}





\section{Botanical Gazette}

DECEMBER, 1903

ON THE GEOGRAPHIC DISTRIBUTION AND ECOLOGICAL RELATIONS OF THE BOG PLANT SOCIETIES OF NORTHERN NORTH AMERICA.

EDGAR N. TRANSEAU.

(WITH THREE MAPS)

By the term "bog-plant societies," as used in this paper is meant that group of plant societies which is commonly found inhabiting undrained depressions and marshy grounds in the northern United States and Canada. In the northern states they have become noted for their possession of such anomalous plants as the sundew, pitcher-plant, tamarack, and cranberry. Although not so well known, the cassandra, rosemary, and Labrador tea are quite as interesting.

“DRAINED SWAMP" AND "UNDRAINED SWAMP" SOCIETIES.

There have been a number of descriptions of these bogs published in connection with local ecological studies, and in several instances have comparisons been máde between them and the other swamps of the region. They are referred to as "undrained swamps," in contrast with the groups of "drained swamp" societies which may be found on adjoining low grounds and along stream courses. The latter group may be briefly summarized by noting that in the region under discussion it is commonly made up of such plants as Typha latifolia ${ }^{\mathrm{I}}$, Scirpus lacustris, Juncus effusus, Carex riparia, Polygonum emersum, P. sagittatum, Cephalanthus occidentalis, Cornus stolonifera, C. candidissima,

'Nomenclature of Britton's Manual of the Flora of the Northern States and Canada, I901. 
Salix discolor, Acer rubrum, Ulmus americana, and Fraxinus americana.

While it often happens that locally the one occurs only in drained conditions and the other only in undrained situations, field work carried on over any considerable area will show that drainage conditions are not adequate to account for the presence or absence of either of these two distinct types of vegetation. The presence of peat, with the consequent accumulation of humus acids, has been commonly spoken of as preventing the coming in of the "drained swamp" types. In southern Michigan and northern Indiana, however, there are many swamps with a thick substratum of peat and without an outlet, yet supporting a vegetation made up wholly or in part of these plants. It is true, however, that the bog societies occur here only in poorly drained situations, underlaid with peat or bogus soil.

Again, it is not unusual to find these two society groups growing on opposite sides of the same lake, where the underlying soil can be shown to be the same. To account for this, it has been suggested that the depth of water in the two situations is of importance. But any ideas of this kind can be disproved by carrying the criteria into a new locality. Just to the west of Ann Arbor, Mich., occurs a small glacial lake. This was formerly surrounded by a quite typical group of bog societies. Within recent years the eastern side of the lake has been entirely cleared, and a large part of the original tamaracks on the south and southwest sides have been cut away. There is left a rather pure growth of bog plants on the northwest side. Since the clearing was made on the southwest side there has sprung up a dense growth of herbs, shrubs, and trees, nearly equaling in height the adjoining grove of tamaracks. But if we note the species prevailing in this area, we find the plants enumerated above as typical of drained swamps. It is practically impossible to account for this situation on the basis of soil difference, chemical character of the soil solution, drainage conditions, or depth of water.

In his paper on the "Physiographic Ecology of Chicago and Vicinity" Cowles ${ }^{2}$ distinguishes one "drained" and three

${ }^{2}$ Bot. GAZ. 31 : 145-155. 
"undrained" types of swamps occurring in the area of lakes and sand dunes at the southern end of Lake Michigan. Although several species of plants may be common to two or more, he does not believe these societies to be related to one another genetically.

That a certain amount of chance in the matter of seed dispersal must be taken into account in any botanical field problem is recognized. But the fact that "drained" and "undrained" swamps occur in close proximity to one another, each with numerous examples in the same district, seems to require some more adequate explanation.

\section{RELATION TO SURROUNDING VEGETATION.}

Throughout the region of northern Indiana, northern Ohio, and southern Michigan the problem is still further complicated by a seeming absence of all connection between the bog societies and the bordering forests. The zonal succession of plant groups, from the submerged aquatics of the pond to the arborescent forms of the higher bog margin, are clearly defined and well known. But then comes a sudden break, and without a suggestion of gradation the surrounding forest of mature oaks or oaks and hickories appears.

Farther north in Michigan there is no such difficulty in finding a definite order of succession between the bogs and forests surrounding them. For example, a tamarack swamp on north Manitou Island, which is surrounded by a thick forest of maple and beech, shows the following societies arranged almost zonally, beginning with the open pond in the center:

I. Aquatic society. Potamogeton natans, P. lucens, Nymphaea advena, Castalia odorata.

2. Cat-tail-Dulichium society. Typha latifolia, Phragmites Phragmites, Menyanthes trifoliata, Dulichium arundinaceum, Cicuta bulbifera, Scheuchzeria palustris.

3. Cassandra society. Chamaedaphne calyculata,-Dryopteris Thelypteris, Sphagnum sp. ?, Kalmia glauca, Sarracenia purpurea, Ledum groenlandicum, Lycopus americanus, Triadenum virginicum, Polygonum Hydropiper, Rubus hispidus, Comarum palustre, Andromeda Polifolia, Chiogenes hispidula, Oxycoccus Oxycoccus, and Eriophorum virginicum. 
4. Shrub and young tree society. Aronia arbutifolia, Ilicioides mucronata, Rosa caroliniana, Ilex verticillata; young specimens of Larix laricina, Betula pumila, Picea Mariana, and Acer rubrum. Beneath these occur a scattering of members of the preceding society, together with Limnorchis hyperborea, Blephariglottis lacera, Gymnandeniopsis clavellata, Osmunda regalis, O. cinnamomea, Dryopteris spinulosa intermedia, Vaccinium canadense, Epilobium lineare, E. adenocaulon, and Viola blanda.

5. Conifer society. This zone is composed of mature tamaracks, black spruces, low birch, and swamp maples; young and mature Betula lutea and Tsuga canadensis; and seeding Acer saccharum. The undergrowth of herbs and shrubs is diminished to a few stragglers. This brings us to the higher ground surrounding the bog, which is occupied by the next society.

6. Climax forest society. Consists of sugar maples and beech trees with occasional hemlocks. The undergrowth is sparse, consisting principally of their own seedlings. ${ }^{3}$

Going farther north into Ontario, the series of societies is not so long, but apparently just as definite. But we have there passed the northern limits of our broad-leaved mesophytic trees and the climax stage is reached in a mixed forest of pine, spruce, and fir. This same statement probably holds for the great coniferous areas of Wisconsin, Minnesota, New York, northern Pennsylvania, and the New England states. Even so far south as northern Indiana, in the sand-dune region, Cowles ${ }^{4}$ has shown that where the surrounding vegetation consists of pines there is no doubt the same order of succession.

It appears then that where the northern conifers are dominant or make-up an integral part of the forests, the ecological relations of the bog societies are clear. In other words, they normally represent one physiographic starting-point for the development of the great conifer forest formation.

There remain therefore at least two questions to be solved:

${ }^{3}$ See also Whitford, H. N., The genetic development of the forests of northern Michigan. Bот. GAz. 31:315. 1901.

4 Loc. cit., p. 150. 
First. What relation do these bog societies bear to the surrounding vegetation of oaks and hickories as they occur in Ohio, Indiana, and southern Michigan?

Second. How can we account for the presence of bog societies and swamp societies (or mixtures of the two) when found in adjacent areas, having similar drainage and soil conditions?

\section{PRESENT DISTRIBUTION OF BOG PLANTS.}

In order to obtain a better understanding of these questions, data on the geographic distribution of bog plants were collected and maps drawn. It soon became evident that the number of species would have to be limited and that only those which are characteristic of these situations across northern North America could be considered. The number was finally reduced to fifteen. Beginning with those which first find a foothold in such depressions and continuing in their approximate order of advent, they are: Menyanthes trifoliata, Dulichium arundinaceum, Comarum palustre, Scheuchzeria palustris, Eriophorum polystachyon, Drosera rotundifolia, Sarracenia purpurea, Oxycoccus Oxycoccus, Chiogenes hispidula, Andromeda Polifolia, Chamaedaphne calyculata, Ledum groenlandicum, Kalmia glauca, Betula pumila, and Larix laricina.

Finally the accompanying map ( $f g . I$ ) was drawn by superimposing the areas of North America in which each of these plants commonly occurs. In the course of its construction some interesting points in geographic distribution came to light. The dark area extending from the Atlantic to the Mackenzie basin represents a great center throughout which all these plants appear in most bogs. The lighter shaded areas north and south represent territory in which only a majority of the forms occur in the average bog, while in the lightest shaded portions only a minority of them are to be found.

\section{ClimATE OF THE OPTIMUM REgION.}

The region of optimum distribution is limited by certain climatic barriers. On the southwest its limits coincide closely with those of the forests. Beyond this area the relation between rainfall and evaporation makes the conservation of water in 


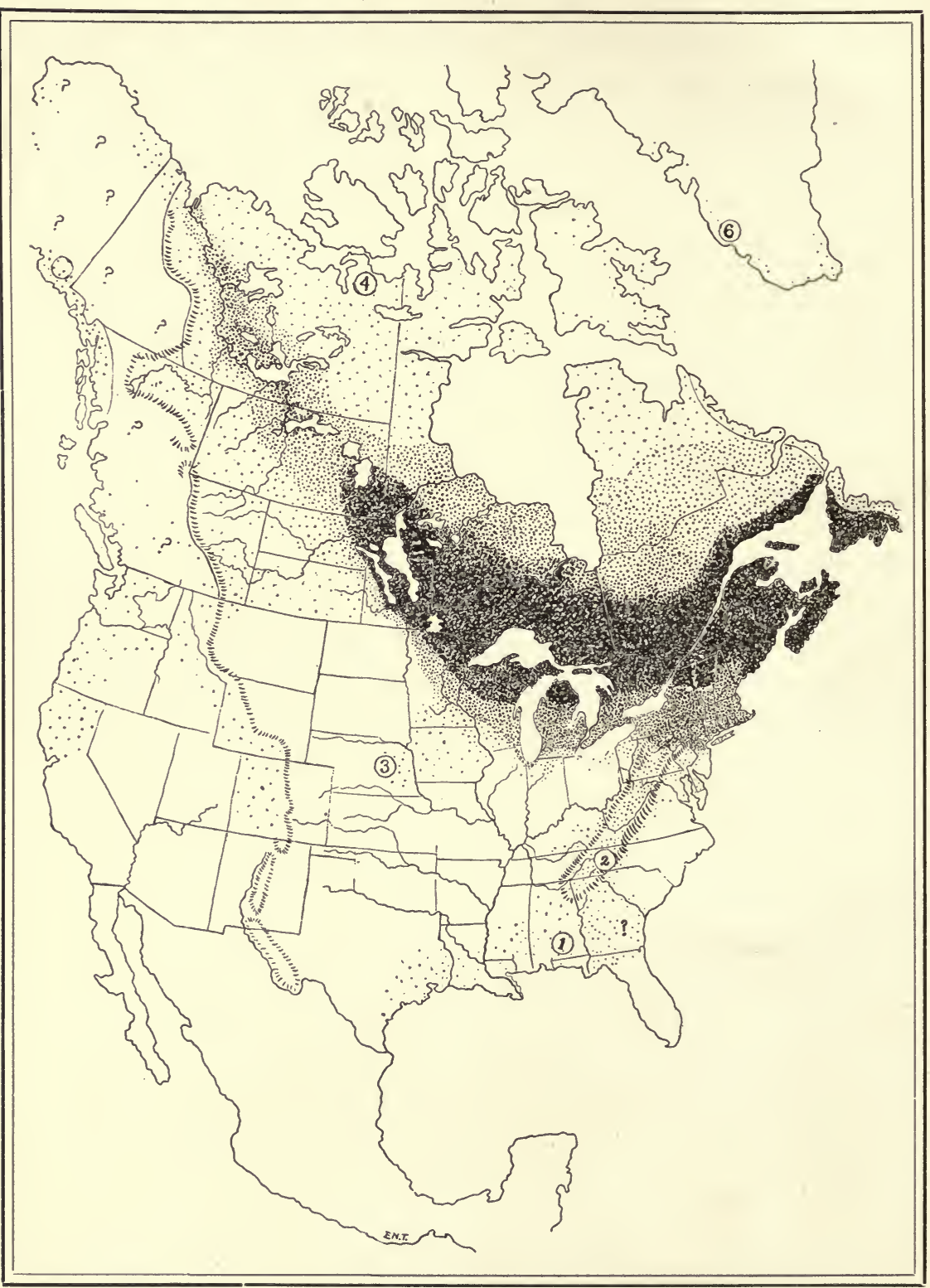

FIG. I. - Map showing distribution of bog plants. (I) Drosera, Dulichium. (2) Sarracenia, Drosera, Dulichium, Eriophorum, Chiogenes, Chamaedaphne. (3) Dulichium, Menyanthes. (4) Drosera, Comarum, Menyanthes, Eriophorum, Ledum, Andromeda. (5) Drosera, Comarum, Menyanthes, Eriophorum, Oxycoccus, Andromeda, Ledum, Kalmia, Chamaedaphne. (6) Menyanthes, Oxycoccus, Ledum, Andromeda, Kalmia. The presence of a large number of shrubs in Alaska and Greenland is probably connected with their preservation there during glacial times. 
depressions throughout the year impossible. On the south and southeast, while the rainfall and relative humidity are favorable, the intense insolation of the summer months seems to be the controlling factor. The northern boundary coincides with that of the northern limits of dense forests. According to Kjellman, 5 Kihlman ${ }^{6}$ and Warming, 7 this boundary is controlled by the amount of snowfall, exposure to dry winter winds, and the length of the growing season. There does not appear to be any relation between the distribution of this group of plant societies and the "life zones" distinguished by Merriam. ${ }^{8}$ Within the belt of optimum conditions the climate is characterized by great range of temperature, both daily and annual. As we go toward the east from the Mackenzie basin, this is modified by the increase in relative humidity. The summers are short, bright, and warm, with abundant rainfall, principally in the form of thunder showers. The winters are long, and extremely low temperatures may occur. The snowfall increases from a foot or two in the western part to several feet in Ontario and the St. Lawrence basin. In the Northwest Territories, where the tundra vegetation is dominant, the ground below a depth of a few centimeters is frozen practically throughout the year. Since air temperatures of $2 \mathrm{I}^{\circ} \mathrm{C}$. are common in late spring and summer, the plant roots and shoots must there withstand remarkable temperature differences. With the exception of the eastern maritime provinces and Maine, no part of this optimum area is comparable with the conditions which call forth the great bog development of northern Germany and Scandinavia. In the latter localities the bogs are confined to depressions, but may occur in a variety of topographic situations. They may even invade established forests, and by raising the ground water level destroy the tree covering. 9

5 KJellman, F. K., Aus dem Leben der Polarpflanzen. Leipzig. 1883.

${ }^{6}$ Kinlman, A. O., Pflanzenbiologische Studien aus Russisch-Lappland. Acta Soc. pro Fauna et Flora Fennica 6. 1890.

7 Warming, E., Ueber Grönlands Vegetation. Engler's Botan. Jahrbücher I0. 1888 .

${ }^{8}$ Merriam, C. H., Life zones and crop zones of the United States. Bull. I0, U. S. Dept. Agric. I898.

${ }^{9}$ Ganong, W. F., Raised peat bogs in the province of New Brunswick. Proc. Roy. Soc. Can. II. $3^{4}: 131-163$. 1897 . 
It is also worthy of note that in the southeastern part of this region the bog flora is increased in variety by a large number of plants whuse range is more southerly than that of the typical bog plants. Among these are Vaccinum corymbosum, V. atrococcum, Rhodora canadensis, Aronia arbutifolia, and Viburnum cassinoides. Their distribution points to a northward migration from the southern Appalachians. ${ }^{\text {Io }}$

VARIATIONS OF THE BOG FLORA IN GEOGRAPHIC RANGE.

But the map has a still greater significance. The dark area represents the region in which most of these plants attain their highest physical development. Those who have seen the magnificent groves of tamarack in the north, attaining a height of thirty meters and a bole diameter of a meter, will appreciate this fact when they compare them with the stunted groups of the larch in the bogs near the southern and northern limits.

Again, within this same belt, at least eight of the plants, the buckbean, cranberry, snowberry, rosemary, leather leaf, labrador tea, birch, and tamarack, are not confined to bog areas. They may be said to have there a wider life-range and are to be found in a variety of habitats. The tamarack, for example, is found on the hills and along most of the streams. With the black and and white spruce and pine, it makes up a large part of the forest. Here too the buckbean, leather leaf, Labrador tea, and birch occur along slow streams, and the rosemary, snowberry, and cranberry in moist ravines and rich woods.

Just as striking, perhaps, is the fact that as we go in any direction away from this optimum region, the first plants to diminish in size and frequency of occurrence are the arborescent tamarack and birch. Then follow in close succession the shrubby forms, and finally the herbaceous species. ${ }^{\mathrm{Ix}}$ This is practically a reversal of the order of their coming into a new area, and, as we shall see later on, this may have some connection with the

${ }^{x}$ ADAMS, C. C., Southeastern United States as a center of geographical distribution of flora and fauna. Biol. Bull. 3:123. 1903.

${ }^{1 x}$ Scheuchzeria palustris is an exception, so far as its eastern distribution is concerned, and has about the same range as Betula pumila, but in the west it reaches its southern limit in Colorado and California. 
migration this vast aggregate of bog societies has made since the glacial period. It also represents an order from the tallest forms to those raised but slightly above the wet substratum.

PREGLACIAL DISTRIBUTION.

Of these fifteen species, three, Dulichium, Sarracenia, and Kalmia, are endemic. The larch and birch are represented in the Old World by closely related forms, while the remaining ten occur in similar habitats in Europe and Asia. This naturally points to their origin, and certainly indicates their preglacial distribution to have been in the circumpolar regions of both continents. It also implies that these great land masses must have been connected for a long time during the Tertiary period, so that migration from one to the other was by no means difficult. Whether these forms originated in a single polar area is of little consequence. They may have arisen partly in America, partly in Eurasia, but they were essentially the products of similar conditions and by migration came to be associated.

\section{THE GLACIAL MIGRATIONS.}

With the coming on of the cold period, which closed the Tertiary and inaugurated such extremes of climate between the equator and the poles, the consequent accumulation of ice on these northern continents destroyed the ancient habits of these plant societies. At the same time semitropical species, which were common alike to high and low latitudes, were killed by the increasing cold, the ground they had covered affording new areas for occupancy. By the reversal of the drainage lines and consequent destruction of low-ground vegetation, new habitats suited to these plants arose in advance of the ice invasion. Just as the zones of vegetation in a small lake move toward the center, because that is the only direction in which development is possible, so these plants spread away from the centers of ice accumulation. Where this migration moved to the west the plants were later on destroyed, but their southward extension brought them into areas which were not within reach of the subsequent ice invasion. Their adaptations for rapid seed dispersal are not 
notable, except in the case of the Dulichium and cottongrass. The larch and birch have winged seeds, while the remainder would seem to be dependent upon transportation by birds and water currents. But the fact that the plants have survived the ice advances proves that they were easily able to establish themselves in new areas as rapidly as the climate changed. Not less than five such geographic migrations of more or less latitude, corresponding with the five glacial epochs, must have occurred. Between them were intervals. when the temperature, as shown by plant and animal remains ${ }^{32}$ found in interglacial deposits, was fully as high as at the present time. If we consider this proved, then the only glaciation which could materially affect the distribution of our boreal societies today is that of the last or Wisconsin epoch. Through the work of Chamberlin, ${ }^{13}$ Leverett, ${ }^{14}$ Salisbury, ${ }^{15}$ Upham, ${ }^{16}$ and others, the limits of this ice invasion have been definitely mapped.

In order to get an idea of the distribution of the boreal plant societies during the maximum glaciation, let us try to picture what would become of these same societies if a similar period of glaciation were to come upon them now. A sufficient time has probably intervened since the last glacial epoch to allow of almost perfect climatic adjustment on the part of the tundra and conifer societies, so that the climate now most favorable for their development may well have characterized a zone just beyond the ice margin. This zone would gradually move with the increase of the ice fields until it would come to occupy the position shown in fig. 2. According to Chamberlin, the climatic conditions pre-

${ }^{x 2}$ Coleman, A. P., Glacial and interglacial beds near Toronto, Jour. Geol. 9: 285. I901. Penhallow, D. P., The Pleistocene flora of the Don Valley. Rept. Brit. Ass. Adv. Sci. I900: 334 .

${ }^{13}$ Chamberlin, T. C., Classification of American glacial deposits. Jour. Geol. 8: 270; The glacial phenomena of North America, Geikie's Ice Age, 3d ed. p. 274. I894.

${ }^{34}$ Leveretr, F., Changes of climate indicated by interglacial beds. Proc. Bost. Soc. Nat. Hist. 24 : 455. I890.-The Illinois glacial lobe. Mon. 38, U. S. G. S.-The glacial formations and drainage features of the Erie and Ohio Basins. Mon. 4I, U. S. G. S.

15 Salisbury, R. D., and Atwood, W. W., The geography of the region about Devils Lake and the Dalles of the Wisconsin. Bull. 5, Wis. Geol. and Nat. Hist. Sur. Salisbury, R. D., Glacial geology of New Jersey. Rep. State Geologist N. J. 5. 1902.

${ }^{16}$ Upham, W., The Glacial Lake Agassiz. Mon.25. U. S. G. S. 1896. 


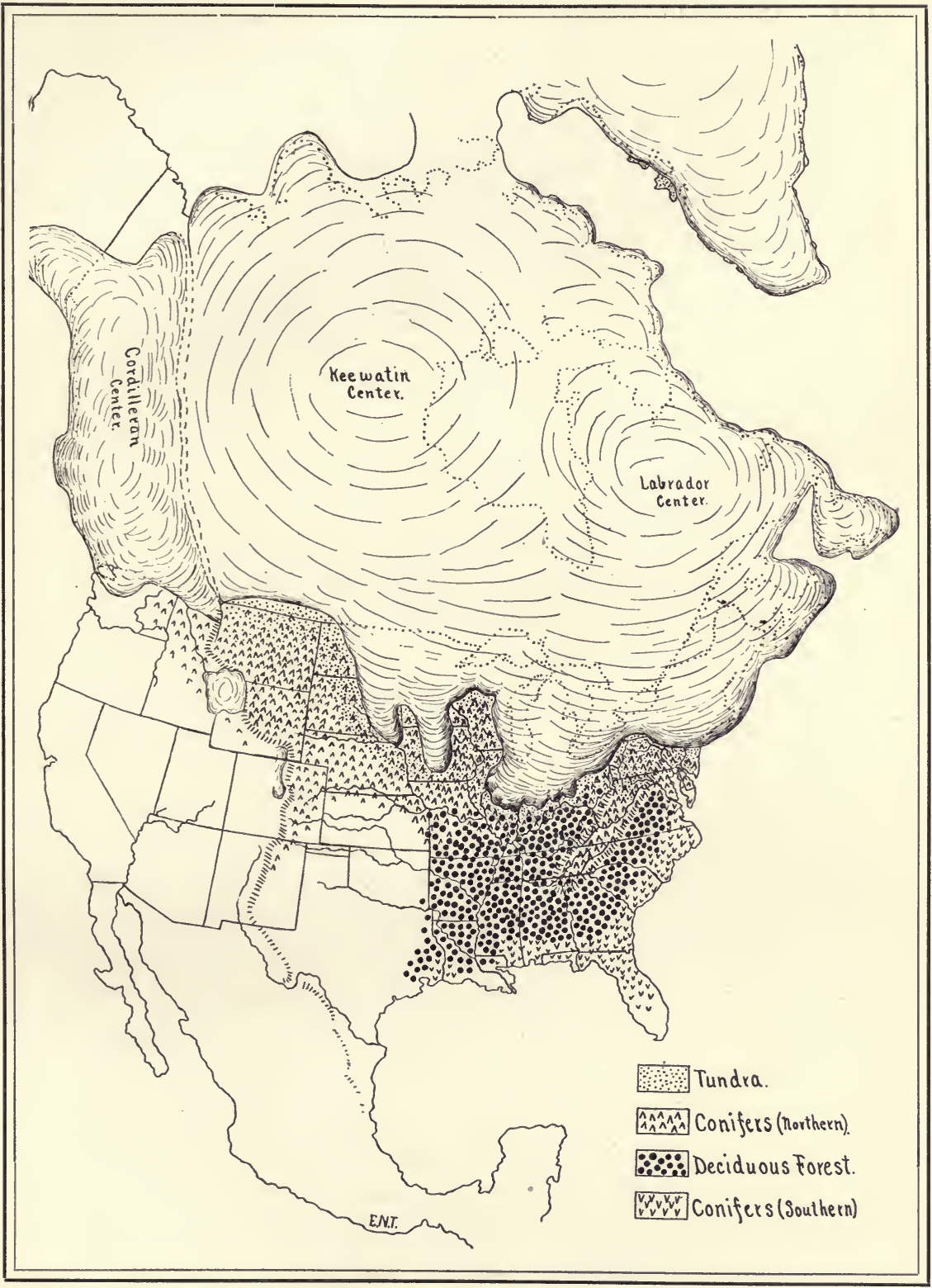

FIG. 2. - Map showing hypothetical distribution of forests and tundra during maximum glaciation of the Wisconsin Epoch. 
vailing about the margin were intermediate between those of Greenland and Alaska at the present time. In the former case the vegetation is sparse and of tundra type, in the latter the forests occur on the stagnant ice margin. ${ }^{x 7}$ It would appear then that the glaciers would not affect the tree distribution at any great distance from the ice front. But there are other factors which would affect the breadth of the zone of conifer dominance. As we may learn from their present distribution, a dry climate, a youthful topography in which erosion is active, high elevation and sterile soil, all of which imply great variations in temperature and relative humidity, are more favorable to conifers than to broadleaved deciduous trees.

It should also be noted in connection with the development - of the continental glacier that, as the ice sheets spread from the two great centers of accumulation, they unite in the region north of lakes Superior and Huron. With their near approach to the lakes, the area of conifers is divided into an eastern and western section. As the development proceeds toward the Wisconsin terminal moraine, the western section would be forced toward the Great Plains, while the eastern division would spread south to the Appalachian highlands and coastal plain.

But in the interior the Ohio basin was occupied by the oaks, ash, hickories; elms and maples. Judging by the present northern limits ${ }^{18}$ of some of these species it is doubtful if the conifers could compete with them at any great distance from the ice front, so that the belt of tundra and conifers may have extended as far south as the Ohio, but it seems probable that even north of this river species of oak, ash elm, and maple persisted.

\section{DISTRIBUTION DURING MAXIMUM GLACIATION.}

To be more definite, let us briefly note the conditions that would prevail during the time of maximum extension, from the Atlantic to the Rockies. In New Jersey, with its extensive area of sand and slow-flowing streams, conditions must have been

${ }^{17}$ Russell, I. C., Glaciers of North America. Ginn \& Co. I90I.

${ }^{18} \mathrm{BELL}, \mathrm{R}$., The geographical distribution of forest trees in Canada. Scot. Geog. Mag. $13: 28$ 1. 1897. 
favorable for a wide-spreading zone of boreal societies. In Pennsylvania the high relief of the Appalachians and consequent low temperature also afforded exceptional opportunities for the spread of these societies far to the south. Here too the cold water of the glacial drainage pouring down the numerous tributaries of the Allegheny, Susquehanna, and Delaware rivers may have had a marked influence by lowering the temperatures of the narrow valleys, just as the streams which flow from Mount Katahdin and the glaciers of Mount Hood (Cowles) and Mount Shasta (Merriam) ${ }^{29}$ affect the temperature of their adjacent. valleys today. The presence of many such northern forms as the white pine, spruce, and hemlock in areas of the southern Appalachians has long been attributed to the glacial period. ${ }^{20}$ In the Ohio valley the streams flowing from the south would aid in maintaining equable temperatures and preserving the broadleaved mesophytes as far north as the Ohio River. Beyond the Mississippi the conditions must have resembled those now prevalent in the Saskatchewan basin. Bessey ${ }^{2 x}$ reports the occurrence in Nebraska of deposits of "well defined branches, twigs and occasionally tree trunks" at depths varying from twenty to fifty feet below the surface, and concludes that in recent geological times there must have been extensive conifer forests throughout the state. The present distribution of trees in Nebraska shows outliers of the western yellow pine (Pinus ponderosa scopulorum) in the central part of the state far removed from the main area of its occurrenee.

Now as to the bog plants: since under favorable conditions they may occupy other habitats than undrained depressions, they probably existed on the borders of the heavily loaded streams, in ravines and moist situations generally along the whole ice front. It is to be noted that practically all of the

rg Merriam, C. H., Results of a biological survey of Mt. Shasta, California. North Americana Fauna no. 16. 1899.

$2^{\circ} \mathrm{Gray}, \mathrm{A} .$, Forest geography and archaeology. Amer. Journ. Sci. and Arts III. I6:85. I878. Hooker, J. B., The distribution of North American flora. Amer. Nat. 13 : 155. 1879 .

${ }^{23}$ Bessey, C. E., The forests and forest trees of Nebraska. Ann. Rep. Neb. State Bd. of Agri. I 888 : 93. 
existing small lake areas of the northern states were covered by the ice during the maximum extension of the Wisconsin ice sheet. As there is no reason to believe that the drift sheets of the preceding epochs, which in many places extend beyond the Wisconsin terminal moraine, contained such small undrained depressions, it follows that the bog societies must have occupied other habitats.

\section{POSTGLACIAL NORTHWARD MIGRATION.}

With the renewal of a milder climate and the consequent recession of the glaciers, the plant societies would gradually spread in the direction of continuous habitats and generally northward. The bog and tundra types would be the first to push into the barren ground left by the retreating ice. The area over which they spread in early postglacial times must have been very much more extensive even than that now occupied by them. In the smaller glacial depressions where absence of wave action would favor littoral vegetation, the bog plants would become firmly established. On the western and eastern sides of the glaciated area the tundra would be closely followed by the conifer forests.

In the west the spreading of the conifers to the north was followed by their gradual destruction in the southwest, due to the increase in temperature as compared with the rainfall. It is possible that the rainfall in Nebraska was never any greater than at the present time. But the decrease in transpiration accompanying decrease in temperature might account for the presence there during glacial times of trees which cannot live under present conditions. The bog plants perished with the conifers and their southwestern boundaries today correspond with that of the forest.

In the east, among the highlands, exceptional circumstances were afforded for the preservation of these northern forms. Many relicts still crowd the higher elevations as far south as western North Carolina.

But in the northern Ohio valley, with its scant conifer vegetation, the areas which at that time supported the bog societies 
were encompassed by broad-leaved forests. The oaks, hickories, maples, ash, and elm, following the lines of their specific habitat, the stream valleys or uplands, the sandy stretches left by glacial drainage, or the long lines of clay moraines, surrounded them in their northward progression.

Probably if the pines, spruce, and hemlock had ever been dominant in Ohio, Indiana, and southern Michigan we should find some evidences of their former occupation by way of isolated conifer areas. Excepting the southern and eastern shore of Lake Michigan and two small groups of pines in Ingham and Calhoun counties, Michigan, no conifer areas occur south of the'Grand and Huron River valleys. When the early settlers moved into the region of southern Michigan, its forests were of the type commonly known as "oak openings." Probably no type of broadleaved forest would be more favorable for the preservation of conifer areas had they been dominant for any great length of time after the ice retreat. Where they have been planted within this region, they flourish and attain their normal proportions. Judging by the present distribution of Pinus Strobus and Pinus resinosa, the character of the soil in the vicinity of lakes Michigan, Huron, and Erie, and the meteorological conditions associated with these lakes, it seems probable that the conifers have reached their present distribution in the lower peninsula of Michigan by way of the lake shores. Probably the great bulk came by way of the southern end of Lake Michigan and from Ontario.

In the west, the north, and the east, then, the xerophytic bog societies are still found with their natural associates, the conifers (fig. 3). But in the Ohio valley they have been surrounded by a vegetation which bears no direct relation to them. Naturally, therefore, we should not expect to find an order of succession between them. This seems to be the answer to the first question proposed.

RELATION OF BOG SOCIETIES TO THE SWAMP SOCIETIES.

This also gives us a new basis for answering the second question, as to the presence of the bog societies and swamp societies 


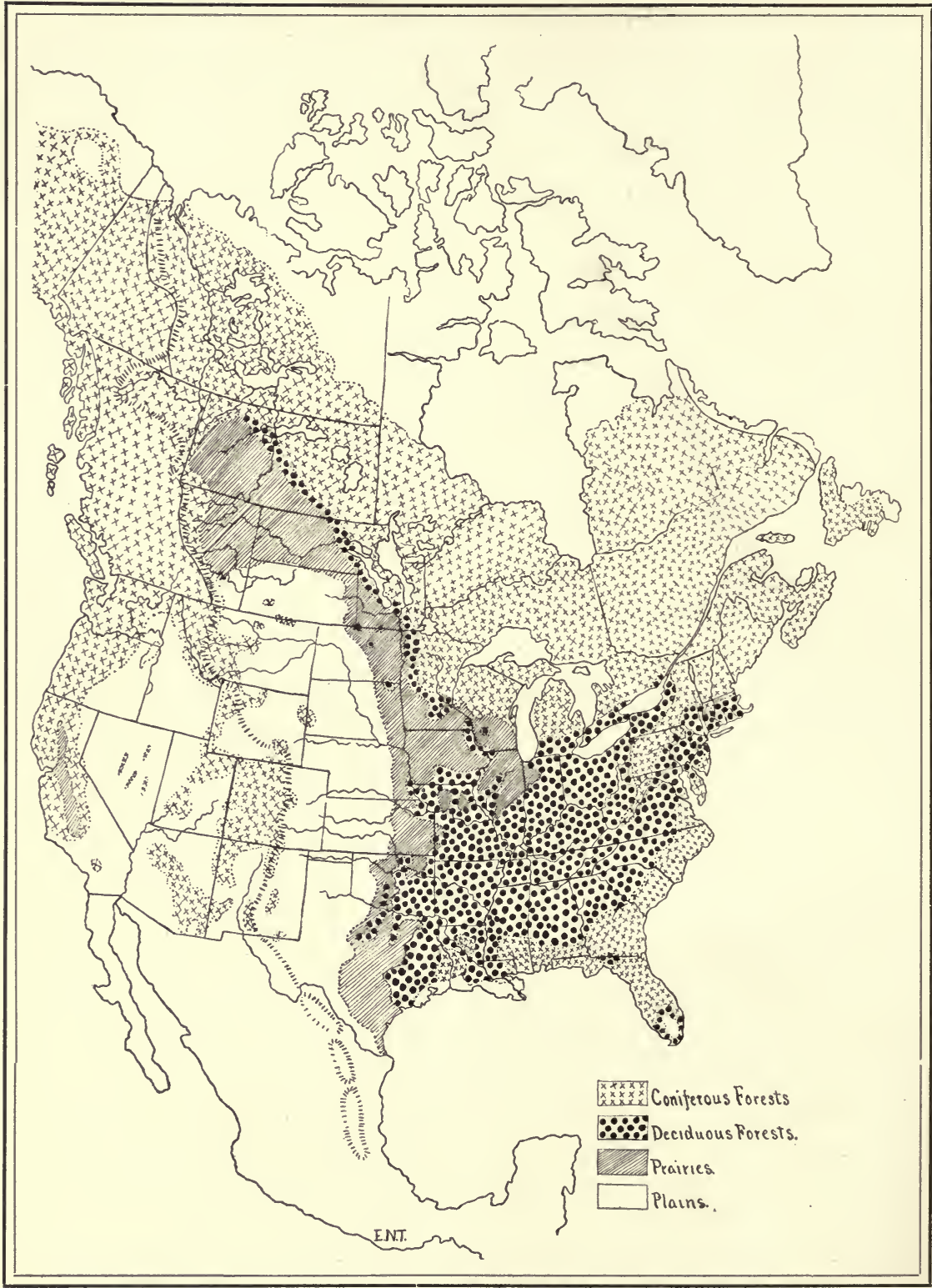

FIG. 3. - Map showing present distribution of forest, prairie and plains. (After Sargent, Ioth Census, Vol. 9.) 
in adjacent areas. As we know from the numerous physiographic studies that have been made of glacial basins, many of the lakes were formerly much larger than at present. Some of them in early postglacial times had steep banks, which were unfavorable to the development of shore vegetation. But by the lowering of the water level consequent upon the cutting down of the outlet, the shore line at present is a gradually sloping one, and supports a "drained swamp" flora. In other cases irregular arms, extending away from the main body of the lake and protected from wind and wave action, doubtless supported a bog vegetation during the tundra dominance. Since then they have been separated from the main lake by a lowering of the water level. Today we find in many such cases the bog vegetation still persisting in the depressions which were formerly arms of the lake, while on the shore of the main body, which came to be swampy at a much later period, the so-called "drained swamp" flora occurs. One of the best examples of this is Turkey Lake, Indiana. Here is an irregular lake several square miles in extent, nearly surrounded by high moraines. At its southeastern end, through a less elevated portion of the moraine, it formerly connected with several shallow depressions, ${ }^{22}$ all of which contain bog plants with varying proportions of swamp plants. But on the now shallow margins of the present lake only the swamp plants are found. At Eagle Lake ${ }^{23}$ the same observations hold for a former extension of this lake toward the northwest. But without multiplying examples, the relation of these two groups of swamp societies seems to depend largely upon the time when the swamps came into existence as swamp habitats. If they have existed since the days of tundra conditions they may show. a bog flora today. If they are of recent origin, the plants will correspond to the normal swamp plants of the present climatic conditions. If of intermediate age, we may have various mixtures of the two. Dr. Cowles informs me that the only bog in the sand-dune region near Chicago which contains all these typical bog plants is the one that occurs on the Valpa-

${ }^{22}$ For map and description of lake see Proc. Ind. Acad. Sci. I895.

${ }^{23}$ Map opposite p. I 18 , Proc. Ind. Acad. Sci. I90 I. 
raiso moraine. When this basin was formed the area occupied by the other bogs was still covered by the waters of Lake Chicago (now Michigan). At the present time new bog areas are being continually added by the interference of the moving dunes with drainage lines. And these new areas frequently contain a number of the bog plants. This, however, does not invalidate the explanation here suggested. The bog habitat has been continuous since early postglacial times; only its position and extent have been variable.

This same observation holds in the case of certain lakes which have long supported a growth of the bog plants at some part of their shore line. By recent gradual changes of level, or by the development of a floating sedge and cassandra zone, these areas have been greatly enlarged in recent times. Usually, however, such formations are partially made up of swamp species.

It is a well-known fact that in many localities where the bog societies formerly existed, they have partially or entirely disappeared. Since the settlement of this region, extensive bog areas have been cleared and drained. Fires have aided in the destruction of the tamaracks, and in many places the sudden lowering of the water level due to ditching has resulted in the killing of a large part of the original bog flora.

In this connection it is to be noted that the partial clearing or burning of a swamp area opens up a new territory for occupation, either by the bog plants or the swamp plants. The preservation of the underground stems of many of the bog species makes their chances more favorable for capturing the area in question. But there are many areas to the west of Ann Arbor which show that these bog plants cannot compete with the swamp plants in the occupancy of new territory, even though the bog plants be in complete possession previous to the clearing. We may say that the chances of capturing newly exposed land areas at the present time are all in favor of the swamp plants, largely because of their greater production of seeds, more adequate means for seed dispersal and better adaptations to present climatic conditions. In early postglacial times, however, the conditions were far different. The swamp plants had been 
driven further south. "The climate being more boreal in its character favored the bog plants, so that they became practically the only competitors for the low-ground situations.

The preservation of the bog societies in poorly drained situations down to the present time seems to be due (I) to the lower temperatures prevailing there, (2) to the sterile nature of the substratum, (3) to the completeness with which the substratum is occupied by the bog plants, and (4) to the fact that most bog habitats are associated with lakes, whose basins must be entirely filled with débris, before the drainage conditions will be naturally improved and made more favorable for the coming in of other plant societies.

To account for the xerophytic character of many. of the bog plants, experiments now being carried on seem to indicate that differences of temperature between substratum and air is adequate. But the presence in many of our bog habitats of swamp species which show no xerophytic adaptations suggests that such xerophytic structures may be unnecessary under present conditions in this region.

\section{SUMMARY .}

To summarize the results of this study, we may say that, as shown by their geographic distribution:

I. The bog societies are typical of the colder portions of North America and are closely related to the bog societies of Europe and Asia.

2. They show an optimum region of dispersal having a moist climate, subject to very great temperature extremes. Within this region the plants have a greater range of habitats and an increased physical development.

3. As we go away from this center, either north or south, the first forms to show the effect of climatic change in diminished size and frequency of occurrence are the arborescent species. The species which extend furthest from this optimum region are herbaceous forms.

4. The bog societies are normally related to the conifer forests in their development to a climax tree vegetation.

5. Where surrounded by oaks and hickories, or in general 
when conifers are absent, they show no order of succession to the forest societies. This is to be explained on the basis of the migrations forced upon all boreal societies during glacial times.

6. The absence of conifers in the Ohio basin probably indicates the dominance of broad leaved forms there during glacial times.

Local lake and bog studies seem to indicate that:

I. Present bog habitats are continuations of similar habitats which existed in early postglacial times, when tundra conditions and tundra vegetation were dominant.

2. The temperature phenomena of undrained depressions, containing deposits of peat, are favorable to the preservation of these types.

3. The "drained swamp" and "undrained swamp" classification will not hold over any great area. Undrained and drained depressions are both favorable to the development of the common swamp plants.

4. The bog societies are composed of boreal species and, in so far as the area of Ohio, Indiana, and southern Michigan is concerned, must be considered as relicts of former climatic conditions. The swamp societies, made up of more southerly forms, must be considered as the normal hydrophytic vegetation of the present climatic conditions.

The above results are put forth preliminary to a more detailed account to be published later. It is hoped that by this publication the author may be enabled to secure further data as to bog societies in other localities.

UNIVERSITY OF Michigan. 



Annats of Botany,

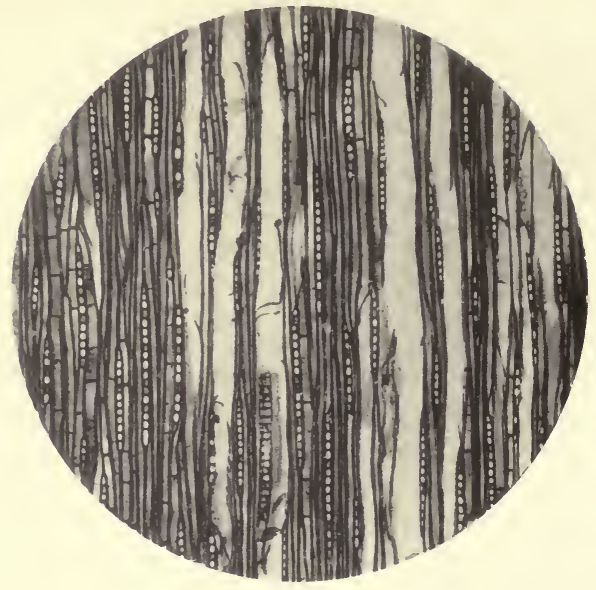

1.

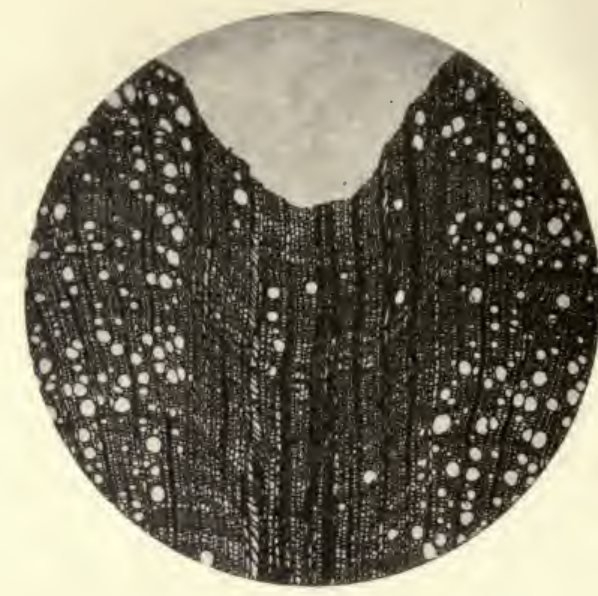

2.

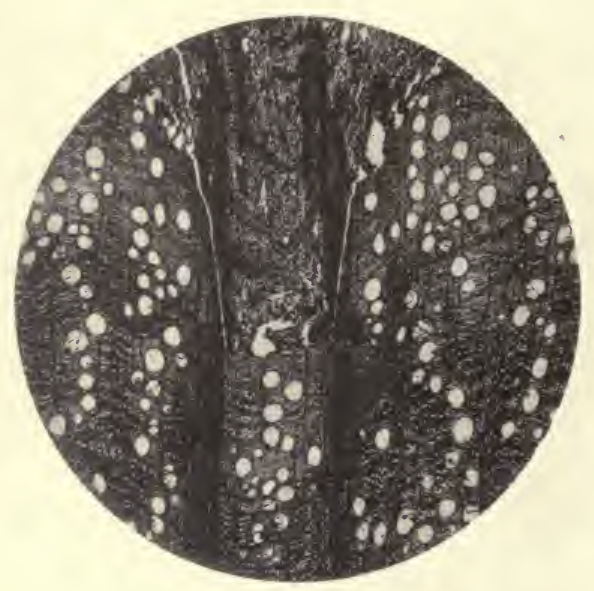

3.

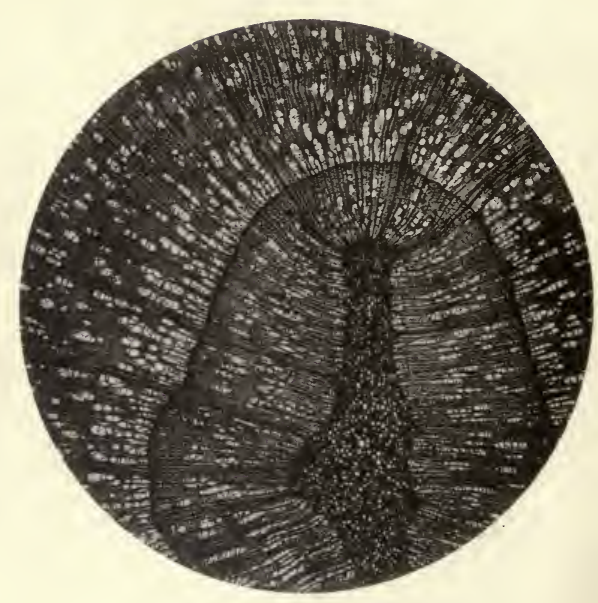

4.
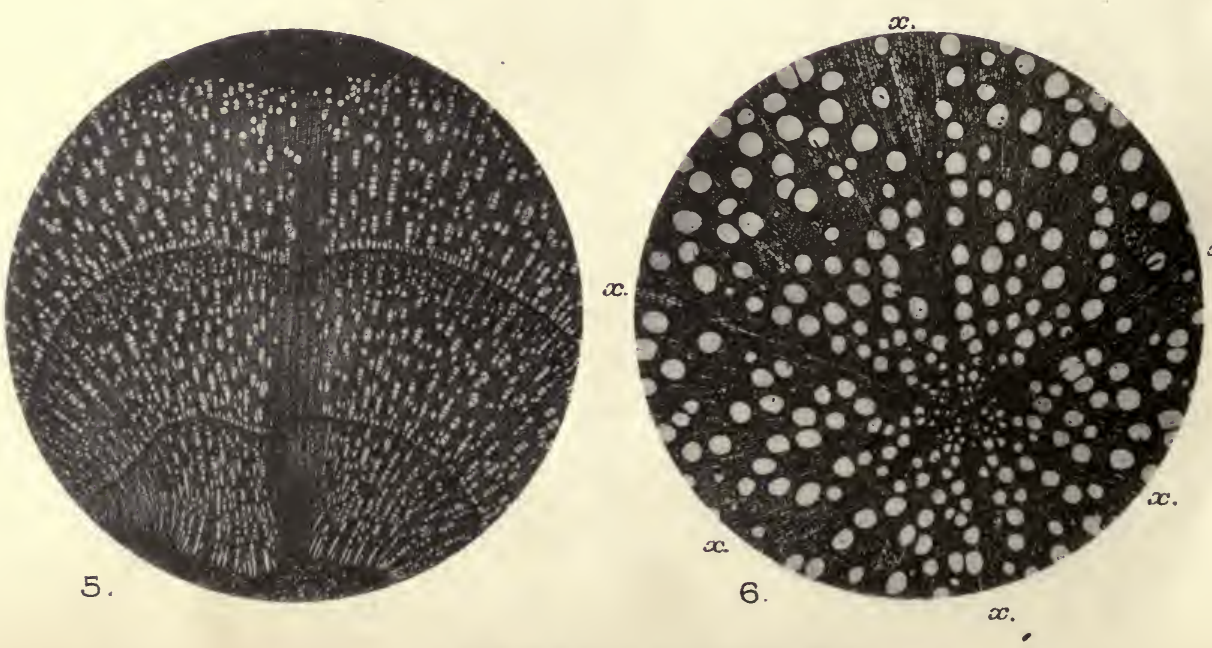

BAILEY - FOLIAR RAY. 
Vol. XXVI, Pl. LXII.

$x$.

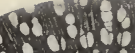

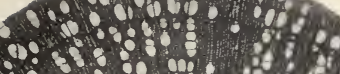

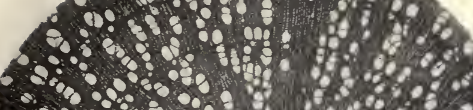

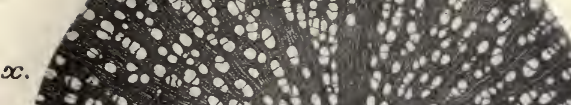

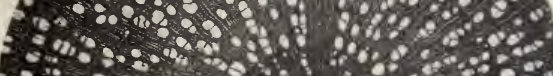

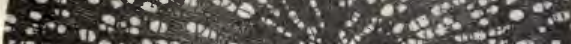

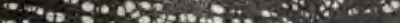
$x$.

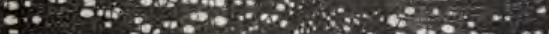

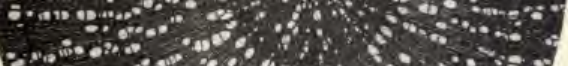

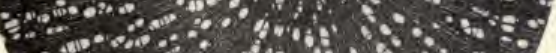

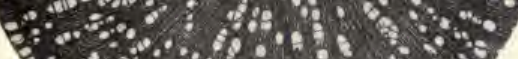

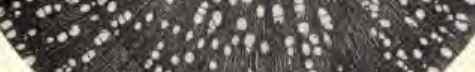

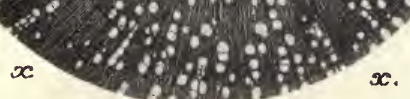

7.

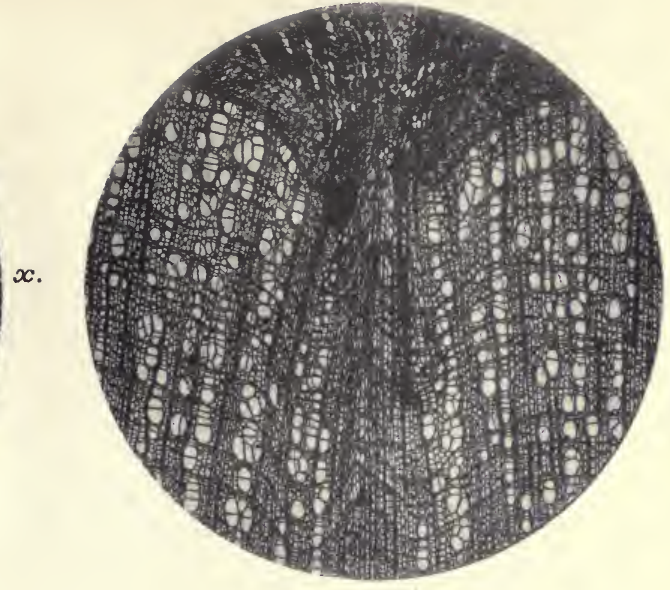

8.

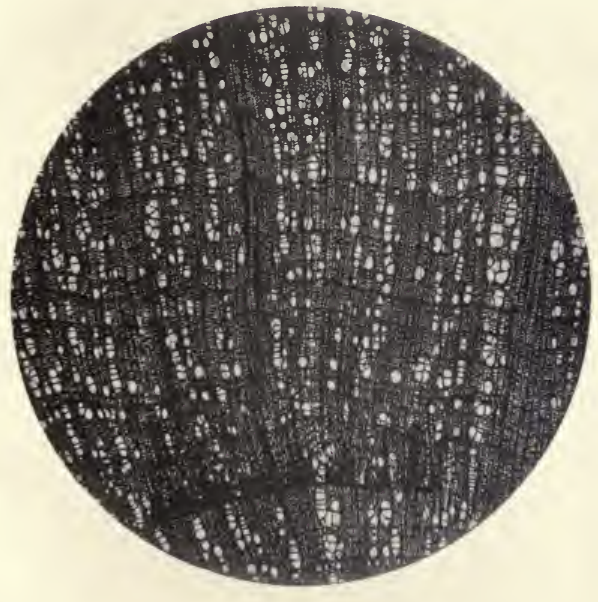

9.
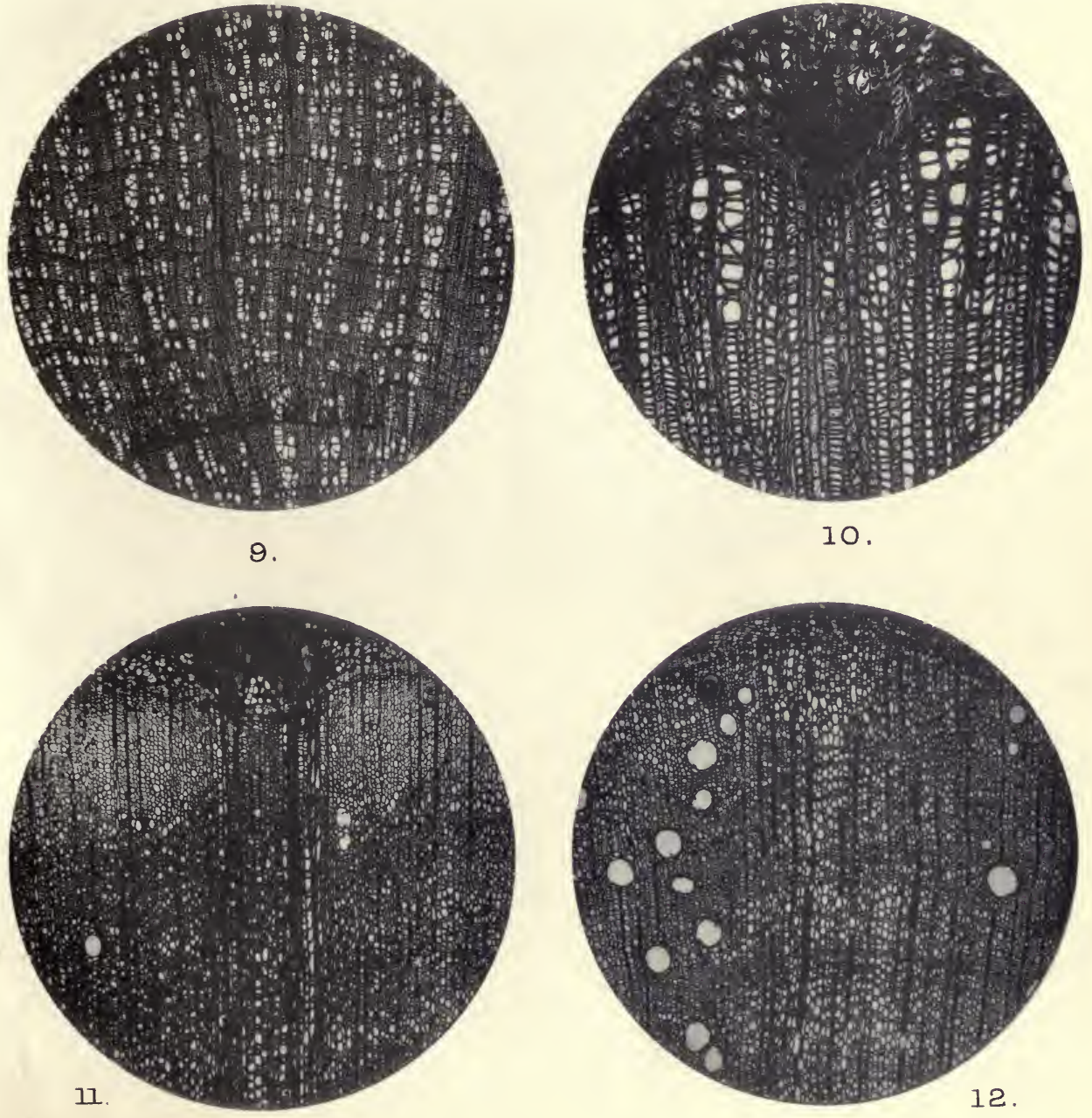

Huth, coll. 


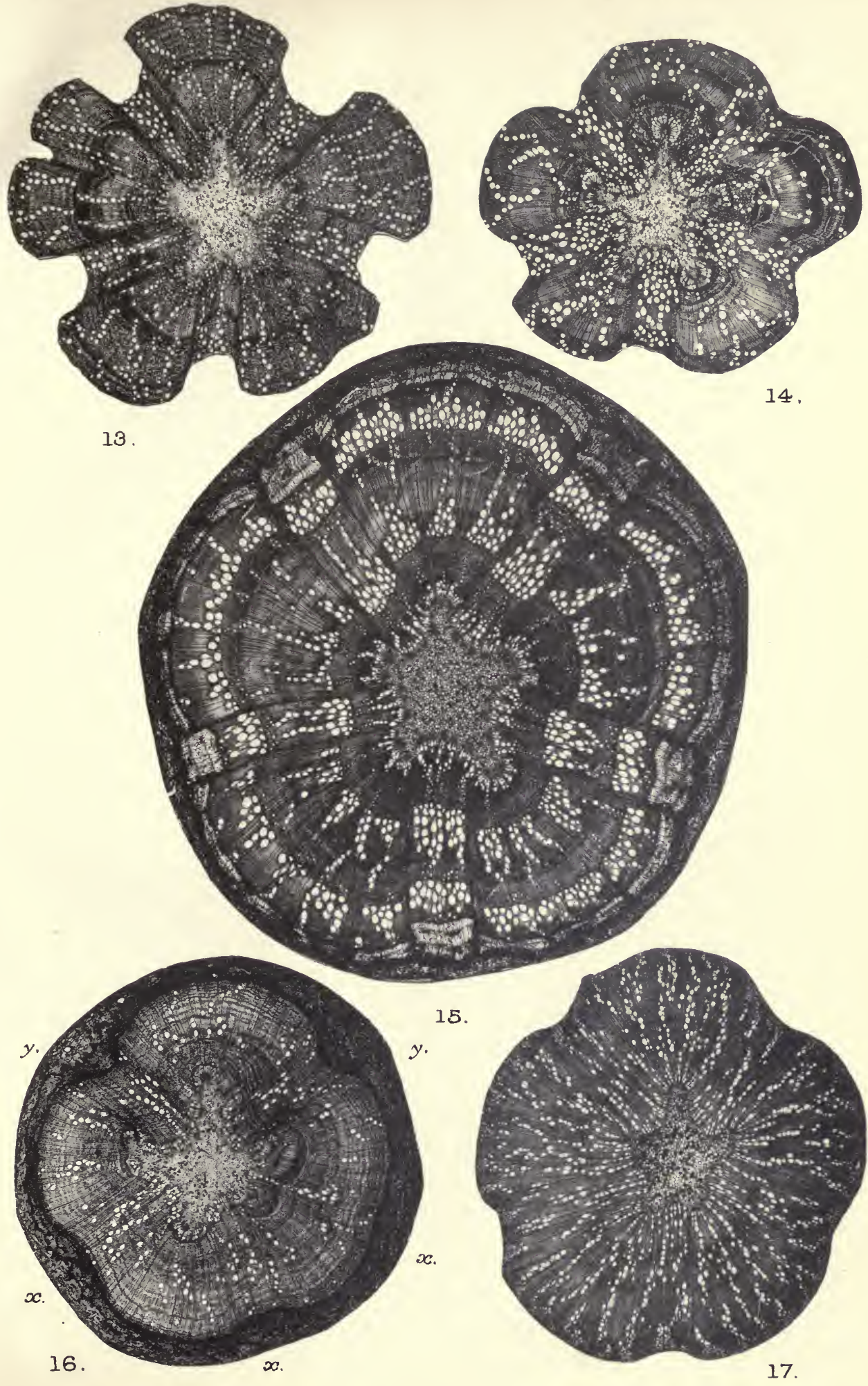

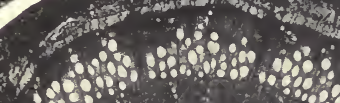

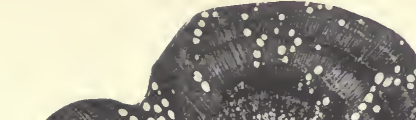

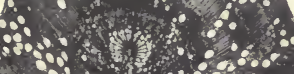

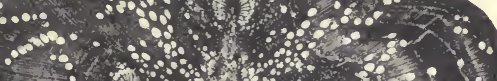

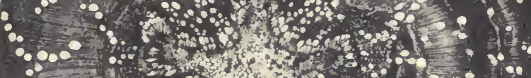

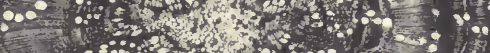

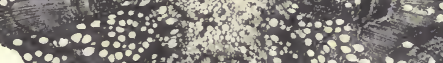

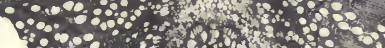

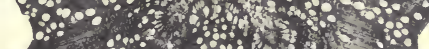

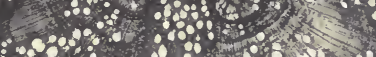

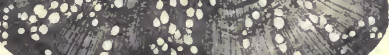

13 4. 19808

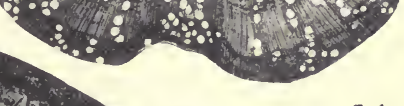

14.

BAILEY - FOLIAR RAY. 


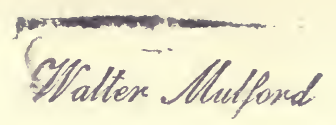

\title{
The Evolutionary History of the Foliar Ray in the Wood of the Dicotyledons : and its Phylogenetic Significance. ${ }^{1}$
}

BY

\author{
IRVING W. BAILEY, A.B., M.F. \\ Assistant Professor of Forestry at Harvard University.
}

With Plates LXII and LXIII.

Evolution of the Foliar Ray.

T I909 Mr. Eames (4) and the writer (1, 2, and 3) conducted a series 1 of investigations upon the broad rays and so-called 'false rays' of the Fagales. The conclusions drawn from these studies have since been published, and may be summarized briefly as follows :

I. Oaks from the Miocene of California are characterized by possessing 'false rays', such as are a distinctive feature of the wood of a large number of living representatives of the Betulaceae.

2. The mature wood of certain Live Oaks of America and Japan possess large rays which are composed of congeries of smaller rays.

3. Alnus rhombifolia, Nutt., and $A$. maritima, Muehl, develop in the older wood large homogeneous sheets of ray parenchyma homologous to the large rays of oaks with deciduous foliage.

4. The earliest formed secondary wood of seedling oaks and alders possesses solely uniseriate rays, such as are a characteristic feature of coniferous plants and many other Gymnosperms.

5. In the mature wood of different species of Alnus a perfect series of stages occur, which demonstrate the 'building up ' of a homogeneous sheet of ray parenchyma from congeries of uniseriate rays and the parenchymatization of fibres included between them.

6. In the development of individual alders and oaks a similar progressive series of compounding stages occur in passing from the younger to the older portion of the stem.

7. Wood which possesses highly developed types of compound ray tissue when injured severely reverts to the primitive uniseriate condition,

1 Contributions from the Phanerogamic Laboratories of Harvard University, No. 47.

[Annals of Botany, Vol. XXVI. No. CIII. July, 1912.] 
and in subsequent growth a recapitulation of the compounding process occurs.

8. Upon the basis of the comparative and developmental anatomy of living and fossil plants and the phylogenetic significance of seedlings and traumatic regions, the uniseriate ray appears to be the primitive type of ray structure in the Fagales, and the large sheets of ray tissue, either of the homogeneous or aggregate type, have developed from them by a process of aggregation and fusion.

In subsequent investigations by the writer $(1,3)$ additional evidence was secured in regard to the origin and development of these structures and their effect upon the stem.

I. Small twigs of Quercus, Almus, Carpinus, and Betula revealed upon the removal of the bark a striking and diagrammatic relation between the sheets of aggregate or compound tissue and the traces of the leaves.

2. A study of the development of ray structures in the Fagales made by means of transverse and tangential serial sections cut through the seedling, young and mature twigs, and large stems, showed the leaf to have been the stimulating influence in the formation of these large sheets of storage tissue.

3. The latter originated as aggregations of uniseriate rays in the immediate vicinity of the leaf-traces, and have been 'built up' and extended vertically and horizontally considerable distances from the node.

4. The large sheets of aggregate or compound tissue which may be called foliar rays, in view of their origin about the entering trace, have an important effect upon the development of the stem, since their rate of growth is in most cases less rapid than that of the rest of the xylem (Pl. LXII, Fig. 2). This is generally expressed by a strong retarding influence upon the growth of adjacent radii of lignified tissue and produces a marked 'dipping in ' of the outline of the annual rings in their vicinity (Fig. 2).

5. The retarding influence of foliar rays is most diagrammatically expressed in small mature twigs of oaks with deciduous foliage, in the stems of certain highly specialized Angiosperms of vine-like and semiherbaceous habit, and in the fluted trunk of the Blue Beech, Carpinus caroliniana, Walt. In the case of the Blue Beech large groups of approximated foliar rays of the 'false type' produce by their retarding effect upon growth the large furrows which are a characteristic feature of the bole of this tree, the ridges corresponding to the segments in which foliar rays are feebly developed or absent. In the mature twigs of oaks with deciduous foliage there are strongly developed foliar rays related to the lateral traces of the leaves. These lateral leaf-trace rays extend downwards through several nodes, and owing to the phyllotaxy of the plant (see Pl. LXIII, Fig. I5), sheets of storage tissue are formed which are relayed from node to node in ten more or less continuous vertical lines along the stem. As is shown in 


\section{Foliar Ray in the Wood of the Dicotyledons.}

Fig. 15 the ten sheets of ray tissue are distributed in five pairs of approximated rays. This approximation of the lateral leaf-trace rays enables their concentrated retarding influence upon growth to depress the included segment of tracheal tissue below the general contour of the stem (PI. LXII, Fig. 3, and Pl. LXIII, Figs. I3, I5). In addition to the lateral leaf-trace rays foliar rays are developed in oak and other plants in relation to the median traces of the leaf. However, in oak these rays are in most cases less strongly developed in the young twig than are the rays related to the lateral traces.

6. The origin and development of foliar rays show clearly that the statements of Sanio, Sachs, and de Bary, pointing to the origin of large rays as inclusions of fundamental tissue or ground parenchyma between putative fibro-vascular bundles and the development of so-called fascicular and interfascicular segments from supposed fascicular and interfascicular cambiums, lead to extremely misleading conclusions.

7. All segments of the stem are essentially 'fascicular', since in the seedling plant of primitive Dicotyledons the stele is an undivided tubular cylinder without indication of the putative fascicular and interfascicular segments and large rays.

8. The development, in relation to the traces of the leaves, of large sheets of storage tissue from congeries of uniseriate rays has a strong dissecting effect upon the stele, producing the supposed fascicular and interfascicular segments of oak, vines, and semi-herbaceous plants.

Eames (5), in an investigation of herbaceous and semi-herbaceous Angiosperms, secured interesting evidence which indicates strongly that herbaceous Angiosperms have been derived from forms which possessed strongly developed secondary growth. In the life-history of many plants there occurs a transition from a tubular stele, in younger portions of the plant, to a ring of separate fibro-vascular bundles in subsequently formed parts of the stem. For example, the prostrate biennial or perennial stems of Potentilla palustris, Scop., as well as the seedling plant, possess an unbroken central cylinder, whereas the cylinder of the erect annual stem a short distance above the rhizome breaks down into a typically herbaceous ring of separate bundles. The herbaceous type of central cylinder has resulted, therefore, from the reduction in size of Dicotyledonous plants in later geological periods, coupled with the evolution of foliar rays whose dissecting effect has been progressively increased.

More recently Professor Groom (6) has published the results of an investigation upon the annual ring and medullary rays of Quercus. There are certain fundamental objections to the conclusion reached by Professor Groom, that 'it is impossible at the present to decide whether in Quercus the broad-rayed or the narrow-rayed type was primitive'.

In studying lines of evolutionary modification in plant structures it is essential not only that a careful study be made of the comparative anatomy 
of normal mature plants, but in addition an intensive study is necessary of the development of structures during the life-history of individual plants. Such developmental studies should be made to cover numerous species selected from as many genera and families as possible. Furthermore, since ancestral characters are known to persist in the seedling, reproductive axis, leaf, and first-formed portion of vigorous mature shoots of plants which have suffered vegetative reduction, and to be recalled in traumatic regions of plants which have been similarly reduced, it is essential that these regions be examined with particular care. Finally, palaeobotanical material, when available, must be regarded as an invaluable check upon conclusions of phylogenetic significance reached from living material.

It is unfortunate that Professor Groom's conclusions are based upon rather narrow foundations. The material used by him consisted evidently almost exclusively of mature oak wood, a large part of which was composed of American species cut from a collection in the possession of this Laboratory. An extensive study of the development of ray structures in the life-history of different species of oak (such as was made by Eames in the case of certain vines and species of the Rosaceae, Ranunculaceae, and other families, and by the writer in the case of many species of the following genera of the Fagales, Quercus, Pasania, Alnus, Betula, Corylus, Carpinus, Ostrya, Castanea, Castanopsis, and Fagus) was not attempted by Professor Groom. Nor did he examine those regions of the plant which retain ancestral characters.

In view of these facts certain criticisms by Professor Groom of the results secured by Eames and the writer are of interest. Professor Groom states: 'From the point of view of the assumption that the seedling is a seat of phylogenetically early structure features, these facts lose their significance if it be shown that a similar "linking up" of small rays to form large ones takes place in older parts. I find that such a "linking up" does take place, at least in connexion with some of the rays of the inner rings of the twigs of Quercus Robur, L.'

It is necessary at this point to emphasize the important fact that the foliar ray has reached varying stages of aggregation and fusion in different species of the Fagales. In Alnus japonica, Sieb. et Zucc., A. rhombifolia, $A$. maritima, and many evergreen oaks the foliar ray is of the aggregate type composed of congeries of smaller rays more or less imperfectly fused. The first-formed wood of the seedling possesses solely uniseriate rays, and the development of foliar rays is a progression in the direction of compounding. In most oaks with a distinctly deciduous foliage and in certain somewhat ring-porous evergreen oaks from the western and south-western part of the United States, the foliar ray is of the compound type, composed largely of a nearly homogeneous mass of parenchyma. In the highest types of this group the fused or compound condition of the foliar ray occurs except 
in primitive parts, e. g. the seedling. In passing from these regions to subsequently formed portions of the stem the development of the foliar ray tissue is a progression in the direction of compounding. The significant facts to be kept in mind are that in Quercus the first-formed wood of the seedling possesses solely uniseriate rays, the development of foliar rays is a progression in the direction of compounding, and more primitive stages of the 'linking-up' process occur in the young plant. The 'linking up of small rays to form large ones in the first rings of the twigs of Quercus Robur' does not invalidate seedling evidence, since in this species the solidifying of the foliar ray may not have worked back to the region of the pith in the early wood of the stem and branches.

An unfortunate difficulty has been introduced by Professor Groom: that the broad solid ray may be primitive in oak, since it apparently undergoes subdivision in many cases. In view of the progression in the direction of compounding which occurs in the development of ray structures in the life-history of oak, alder, and other genera of the Fagales it is difficult for the writer to concur in this turning of the foliar compound ray inside out. That the foliar ray is dissected into shallower sheets of ray tissue in passing horizontally from the young to the older portions of a thick stem is true for all species of the Fagales. This is as true for species in which foliar rays are of the aggregating type as for those higher types in which nearly homogeneous masses of fused ray tissue are related to the traces of the leaves. In 'exogenous' stems which are increasing rapidly in circumference a multiplication of elements, fibres, vessels, parenchyma, and rays must occur with added layers of growth. Therefore the dissection of foliar rays is essential to maintain the proper proportion of ray tissue in the older zones of the stem. However, the impulse which produces this dissection of foliar rays is fundamentally different from that which results in the evolution of storage tissue in relation to the traces of the leaves, and cannot be considered evidence for believing that the broad, solid type of ray is primitive in Quercus. Both phenomena are often active in the same foliar ray. For example, in Almus rhombifolia, Quercus virginiana, Mill, or $Q$. densiflora, Hook. and Arn., foliar rays of the aggregate type are gradually 'built up' in passing from the vicinity of the leaf-trace to the mature portion of a wide stem, yet a dissection of this aggregating mass of tissue takes place in the older wood, resulting in the formation of 'lower' and more numerous sheets of compounding tissue.

In this connexion Professor Groom's conclusions in regard to 'Quercus (Pasania) fenestrata (Q. spicata)' are of interest: 'In $Q$. fenestrata these characteristic high rays are often approximated in pairs, and between the two rays forming a pair the boundary of the annual ring is much nearer the centre of the stem than it is elsewhere (P1. LXXXV, Fig. I2). Moreover, the space between the two rays forming a pair is devoid of vessels. These 
three sets of facts denote that in some way the pair of high rays, together with the tissue between them, is equivalent to a single broad ray; and the very considerable inward dip of the annual ring between the two rays finds simplest explanation in the assumption that in the ancestor the complex mass represented solely ray tissue.' This conclusion is somewhat remarkable in view of the facts pointed out by the writer in a former paper, that the depressed segments of the oak stem are produced (see Pl. LXII, Fig. 3, and Pl. LXIII, Figs. I 3 and I5) by the concentrated retarding effect upon growth of two closely approximated foliar rays. Since these rays are usually related to the traces of different nodes it is difficult to conceive of their origin from the dissection of a single large ray. The writer recently examined material of Quercus spicata, sent from India by courtesy of Mr. R. S. Pearson, Imperial Forest Economist, and is unable to agree with Professor Groom in stating that vessels are absent from the depressed segments included between approximated pairs of foliar rays. Professor Groom for some unexplained reason completely ignores the important relation of the leaf-trace to the formation of large rays, although he refers to the paper by the writer in which this evolutionary process was described.

Since conducting the investigations which have been summarized earlier in this paper a more comprehensive study has been made of Dicotyledonous plants. This investigation has included not only numerous species of the more primitive or supposedly primitive families, but also of the higher or supposedly more recent families. The material used comprised not only species from the temperate regions of North America, Europe, China, and Japan, but in addition representatives of a more tropical flora from India and Australasia. In connexion with instruction upon the anatomy of American woods material of practically all American trees and larger shrubs has been examined. This investigation has confirmed strongly the conclusions reached in regard to the origin, development, and dissecting effect of foliar rays, and has served to emphasize the important part that these structures have played in the evolution of modern Angiosperms. As might naturally be expected in viewing this evolutionary movement from a broader and clearer standpoint, certain obscure and imperfectly understood features have been clarified.

That the evolution of the foliar ray occurred in the early history of Angiosperms is seen from the fact that the most convincing evidence of the compounding process is confined largely to primitive Dicotyledons or to regions of phylogenetic significance, and from the fact that in the majority of woody Angiosperms this primitive type of foliar ray has been changed structurally or completely reduced. This conclusion is further emphasized by the occurrence of well-developed foliar rays in Angiosperms of the upper Cretaceous (11).

In the light of recent investigation the foliar rays appear to have 
developed as aggregations of uniseriate rays about the persistent leaf-traces of evergreen plants of the warmer Mesozoic times. These sheets of storage tissue were subsequently extended increasingly greater distances from the leaf-traces, and gradually compacted by the coalescing and enlargement of the uniseriate rays and the parenchymatization of fibres included between them. Rays of this primitive type which occur side by side with uniseriate rays have persisted to the present time in certain of the more primitive Dicotyledonous families, e.g. Fagales, Casuarinaceae.

\section{DifFUSION OF THE FOLIAR RAY.}

With changes of environment during later geological periods the primitive foliar ray was modified in the evolution of the majority of modern trees and shrubs. This change consisted in the diffusion of the constituent smaller rays of the aggregate sheet of foliar ray tissue. Evidence of this transition, as has been shown by Thompson (12), has persisted in certain Dicotyledons and is particularly well shown in the Casuarinaceae and Ericaceae. In certain species of Casuarina, e. g. C. equisetifolia, L., C. glauca, Sieber, \&c., the typical primitive foliar ray of the aggregate type exists in the younger portion of the stem, but in passing to the older portion the individual rays of the aggregation are diffused throughout the wood. A similar condition exists in Rhododendron punctatum, Andr., Ledum groenlandicum, Retz., and Kalmia angustifolia, L. In somewhat higher types, Fagus atropunicea, Sud., and Platanus occidentalis, L., the foliar rays have been diffused throughout the wood and evidence of the former congeries has been lost. However, serial transverse and tangential sections show that the diffused parts of the former aggregate ray are related to the leaf-traces. It is to be emphasized in view of the conclusions drawn by Groom from Jost's (8) study of Fagus sylvatica, L., that the so-called broad, high rays of Fagus represent diffused and enlarged portions of former foliar aggregate rays. In the majority of higher Dicotyledonous trees and shrubs the process of diffusion is so complete that evidence of the former connexion between the multiseriate rays and traces of the leaves has disappeared entirely.

\section{REDUCTION OF THE Foliar Ray.}

In the wood of a large number of Dicotyledonous plants the foliar ray, either in its aggregate, compound, or diffused form, occurs with the primitive uniseriate ray. There are, however, numerous exceptions to this general rule. Thus the uniseriate ray is seen to disappear entirely from the wood of certain highly specialized Angiosperms (5). Furthermore, individual species of many families of Dicotyledons are characterized by possessing only uniseriate rays. In Pl. LXII, Fig. I is illustrated the tangential section of the mature wood of the common American Chestnut, Castanea dentata, 
(Marsh) Borkh. It will be observed that the wood is characterized by the primitive type of ray structure. A similar condition is found to exist in other members of the Cupuliferae. Thus the mature wood of Castanea pumila, (L.) Mill, Castanopsis hystrix, A.DC., C. Indica, A.DC., Almus acuminata, H.K.B., A. mollis, Fernald, A. yasha, Matsum, \&c., possess characteristically only uniseriate rays. In view of the fact that the first-formed wood of primitive Dicotyledonous plants possesses only uniseriate rays and the foliar ray has been 'built up' from congeries of small rays, it might naturally be supposed that the plants under consideration possessed the primitive type of Dicotyledonous wood from which have been evolved the higher and more complex forms. However, before accepting this supposition as a correct one, a more detailed examination of their structure is necessary. The fallacy of inferring that less complex plants are of necessity more primitive has in recent years been clearly illustrated by the study of the comparative anatomy of living and fossil plants. The pines, which, owing to their complex structure, have been commonly considered the most recent of Coniferous plants, have been shown to be very old geologically, and the supposedly primitive Cupressineae are now known to be of comparatively recent origin, and to have been evolved from more complex ancestors. In other words, in the evolution of living plants may be traced the gradual reduction and disappearance, as well as the origin and development, of specialized tissues. Among Coniferous plants the reduction of resin canals and ray tracheides can be observed in the Abieteae, Cupressineae, and Taxodineae, as well as the evolution of ray tracheides and wood parenchyma in the Pineae. Similarly, among Araucarian plants there exists the reduction of resin canals and Abietineous pitting. It is, therefore, to be expected that among living Dicotyledons reduced forms occur with less complex structures than those of more primitive forms from which they have been derived, and an examination of those regions which are known to retain ancestral characters is essential in determining their real phylogenetic position.

\section{First-Formed WoOd of Vigorous Mature Twigs.}

In Fig. 4 is illustrated the cross-section of a vigorous mature shoot of Alnus mollis. It will be observed that in the first annual ring are numerous large rays of the foliar type. These rays gradually die out in the second and third annual layers of growth, and the wood of the older portion of the twig possesses only the uniseriate rays characteristic of the mature wood of the species. In the first annual ring of twigs of normal growth the large rays are absent and the wood resembles that of the mature stem. Since the phylogenetic importance of the first annual ring of vigorous branches of plants which have suffered vegetative reduction has been pointed out by Jeffrey $(7)$ in the recapitulation of resin 
canals in Sequoia washingtoniana, (Winsl.) Sud., it is to be inferred that the foliar ray has undergone a process of reduction in the alder under consideration. Furthermore, since similar conditions exist in other lower Dicotyledons which possess only uniseriate rays in the mature wood, the conclusion is reached that a considerable number of plants, although not in reality primitive, have reverted by the reduction of the foliar ray to a type of ray structure which characterized primitive Angiosperms.

\section{Vigorous MATURE ROOTS.}

Fig. 6 illustrates a cross-section of a vigorous mature root of Castanea dentata. Six more or less feebly developed large rays $(x)$ radiate from the clusters of protoxylem. A similar condition is illustrated in Fig. 7, a cross-section of a vigorous root of Alnus yasha. In this root five much reduced aggregate rays $(x)$ are seen to radiate from five clusters of protoxylem. In view of the phylogenetic importance of vigorous mature stems the persistence of large rays in vigorous mature roots is significant.

\section{THE NODE.}

In primitive plants which possess well-developed foliar rays these structures originate in the vicinity of the leaf-trace and gradually 'build up' and enlarge in passing from the earliest formed wood of the node to that of the more mature portions of the plant. Fig. 5 illustrates a cross-section of the node of Almus yasha. The foliar ray, which is strongly developed near the leaf-trace and in the first annual layer of growth, gradually disappears in the older wood. This reduction rather than compounding of ray tissue, which occurs also in Castanea, Castanopsis, Almus mollis, and $A$. acuminata, indicates, as do the vigorous ramifications, that the foliar ray was once well developed in these plants and has gradually disappeared except from regions which are known to retain primitive characters. The retention of the foliar ray at the node is to be expected, since ancestral characters have been shown by Scott, Jeffrey, and others to persist in the vicinity of the leaf. The nodes of vigorous mature stems are, therefore, particularly favourable regions for the recapitulation of primitive features, and retain indications of the existence of foliar rays after they have disappeared from the rest of the stem.

\section{Traumatic Regions.}

Valuable evidence confirming the phylogenetic importance of the recapitulation of primitive characters in the regions just mentioned is afforded by a study of the traumatic reactions of the wood of these plants. It has been pointed out above that severe injuries, in wood which possesses well-developed foliar rays, produce a reversion to primitive stages of aggregation and fusion or to the uniseriate condition. From 
this it might naturally be inferred that injuries to the wood of these reduced plants would recall the foliar type of ray. That such is indeed the case is shown by Fig. 8, a cross-section of the wood of Alnus mollis, cut in the immediate vicinity of a severe injury. The injury has obviously produced a large aggregate ray which may be clearly recognized by its retarding influence upon the growth of neighbouring elements and the distinct sag in the outline of the annual rings. A similar condition is illustrated in Fig. 9, a cross-section of the mature root of Almus mollis. The wood at the lower side of the photomicrograph, which was formed before the injury occurred, possesses only uniseriate rays, but in the upper portion of the figure may be seen numerous aggregate rays which originate at the injury. Additional illustrations of the traumatic recurrence of large rays have been observed by the writer in Castanea, Castanopsis, and Almus, as well as in woods which have replaced the compound or aggregate by the diffuse type of foliar ray. Fig. Io, a cross-section of the outer portion of an insect gall in a mature twig of Ostrya virginiana, (Mill) Koch., illustrates the recurrence of an aggregate ray in a type of wood that possesses normally only small bi- and triseriate and uniseriate rays.

\section{Contour of Mature Twigs.}

There remains for consideration a striking piece of evidence in regard to the reduction of the foliar ray in lower Dicotyledonous plants. A characteristic and important feature of the foliar ray is its retarding influence upon the growth of neighbouring radii of the stem (see Figs. 2 and 3). This influence is so strongly developed in many plants that the depression in the outline of the annual rings which marked the former position of the foliar ray persists for some time after the disappearance of the ray. The writer has shown (3) that the fluted stem of the Blue Beech, Carpinus caroliniana, Walt., is produced by congeries of aggregate rays whose concentrated retarding influence upon the growth of certain radii produces the large grooves in the stem. A careful study of this plant shows that the foliar rays of the aggregate type are gradually being replaced by the diffuse condition. (In the closely allied genus Ostrya the diffuse condition is dominant.) In specimens growing under unfavourable conditions the writer has found large stems from which the aggregate ray has disappeared almost completely. However, the characteristic flutes remained, although less strongly developed. These plants were later cut down, and during subsequent growth of the stump (by means of stool shoots) congeries of aggregate rays were recalled in the depressed segments of the new layers of growth. The stimulation of the injury and surplus supply of food substances in the root produced evidently a reversion to conditions which existed before the plant suffered vegetative reduction. In Pl. LXIII, Fig. I7, a cross-section of a vigorous mature shoot of Castanea pumila, 
may be seen five depressed segments. In this twig the foliar ray has disappeared except from the immediate vicinity of the leaf-traces. The normal twig possesses a circular outline, and the foliar ray is not conspicuously developed at the node. This recurrence of depressed segments in vigorous shoots of Castanea indicates that five pairs of approximated lateral leaf-trace rays existed formerly in the mature twigs of these plants, and have disappeared except from the nodes of very vigorous stems. In Castanopsis indications of depressed segments which were once a welldeveloped feature of the plant persist in the normal mature twigs. A crosssection of the node of Castanopsis hystrix is illustrated in PI. LXIII, Fig. I6. Two segments $(y)$ are more strongly depressed upon the upper side of the photomicrograph, due to the fact that the rays related to the lateral leaftraces are persistent at the node. Owing to the phyllotaxy of the plant the three remaining segments $(x)$ are less strongly depressed. Fig. 14 shows a cross-section of the mature stem of Castanopsis indica. In this species the five depressed segments are more persistent between the nodes, and indicate that the reduction of the foliar ray is less complete in this plant than in the preceding species. In Fig. I 3 may be seen the crosssection of a mature twig of Castanopsis tribuloides, a plant whose structure resembles that of Quercus, since the lateral leaf-trace rays are strongly developed in the wood of small twigs. A careful study of the life-history of the plant reveals the fact that the aggregated rays are disappearing in many portions of the root and stem. In Pl. LXII, Figs. II and I 2 are illustrated the remains of aggregate rays which were once strongly developed by the cambium to maintain the proper proportion of ray tissue in the widening stem and root. These facts, considered in connexion with evidence afforded by the recapitulation of primitive characters which occur in vigorous mature ramifications, nodes, and traumatic regions, point conclusively to the reduction of foliar rays in certain Fagales, and indicate that Castanopsis and Castanea are reduced members of the oak family, just as Alnus mollis, $A$. acuminata, and $A$. yasha must be considered reduced species of the genus Alnus.

The uniseriate rayed species of the Salicales (9) and Sapindales (10) have been studied by Miss Holden, and have been found to represent a reduced condition where complex ray structures have been lost in a reversion to the primitive uniseriate type, but among the higher families of Dicotyledonous plants the uniseriate condition has resulted largely from the reduction of foliar rays of the diffused type rather than of the aggregate or compound types. 


\section{Summary AND CONCLUSIONS.}

I. The central cylinder of primitive Angiosperms was a tubular cylinder or siphonostele which possessed strongly developed secondary growth.

2. The wood of the most primitive Angiosperms possessed only uniseriate or linear rays, such as are a well-developed feature of the wood of Conifers and other Gymnosperms.

3. During the warmer times of the Mesozoic sheets of storage tissue were 'built up' from congeries of uniseriate rays, about the persistent leaftraces of evergreen Angiosperms, and were subsequently extended vertically and horizontally considerable distances from the node.

4. This primitive type of foliar ray tissue has persisted, in more or less unaltered form, in certain species of primitive families of the Dicotyledons, e.g. Casuarinaceae, Fagales, \&c.

5. With changes of environment in later geological periods storage conditions were fundamentally modified in the wood of Dicotyledons.

6. In the evolution of the majority of living Dicotyledonous trees and shrubs the individual units (varying greatly in size owing to the enlargement and fusion of the original uniseriate rays which formed the incipient aggregation) of the aggregating mass of foliar ray tissue have been diffused more or less uniformly throughout the stem, and evidence of their former relation to the traces of the leaves has disappeared, except from certain primitive forms, e.g. Casuarinaceae, Ericaceae, Fagales, and Platanaceae.

7. In a comparatively limited number of forms the primitive foliar ray of the aggregate type has been progressively compounded or solidified, and has resulted in the formation of foliar rays of the compound type composed of homogeneous masses of parenchyma, e. g. oaks with deciduous foliage, Casuarina Fraseriana, Miq., Alnus rhombifolia, \&c.

8. In many families of Dicotyledons species exist in which a reversion to the primitive uniseriate condition has occurred as a condition of reduction from foliar rays.

9. Evidence of the reduction of the foliar ray in the Fagales consists of a more or less complete series of progressively reduced species, and of the persistence or recurrence of foliar rays in regions of phylogenetic significance in forms which are very completely reduced.

IO. The importance of experimental plant morphology in the study of phylogeny is clearly illustrated by the Fagales. In its later history the family has suffered vegetative reduction. At the same time storage conditions have been fundamentally changed in the family, resulting in modification of the sheets of aggregated ray tissue which originated about the 
persistent leaf-traces of more luxuriant ancestors. In modern species the foliar ray of the primitive aggregate type has been or is in the process of being reduced, diffused, or compounded. Rapid accumulation of nutritive substances, such as occurs in mature twigs of unusual vigour or in regions where traumatic stimulation exists, tends to produce a reversion to ancestral structure. Thus in reduced forms the foliar ray is relegated to the first annual rings of vigorous mature roots and shoots. Similarly, in species which have suffered reduction or diffusion, the foliar aggregate ray may be recalled traumatically. Furthermore, species which possess foliar rays of the aggregate or compound type under the stimulus of a slight injury accelerate the 'building-up' process. However, diametrically different results are secured by slow or impaired nutrition. Under conditions of this sort the reduced or diffused condition is hastened by the arrested development of the primitive foliar ray. This is clearly shown in specimens of the Blue Beech which have been grown under unfavourable conditions, and by the fact that the common Alnus incana in the northern and colder part of its range has suffered more complete reduction of the foliar aggregate ray than in the warmer southern part. Arrested development due to impaired nutrition occurs also in plants which possess foliar rays that are of the compound or nearly compound type. Thus severe injuries in the oak produce a reversion to primitive stages of aggregation and fusion or to the uniseriate condition.

II. Castanea and Castanopsis are reduced members of the oak family, just as Alnus mollis, A. acuminata, and A. yasha must be considered reduced species of the genus Alnus.

12. Owing to the important part that the foliar ray has played in the structural development of Dicotyledons, the study of its evolution and reduction yields evidence significant in a natural classification of Angiosperms.

13. A more detailed consideration of the comparative anatomy and phylogeny of Dicotyledonous plants indicates conclusively that the existing conceptions of the origin and development of the woody cylinder of Angiosperms must be fundamentally modified to agree with actual conditions which exist among the higher seed plants.

In conclusion, the writer wishes to express to Major Gage, I.M.S., Superintendent of the Royal Botanic Gardens at Calcutta, to Mr. G. H. Cave of the Lloyd Botanic Garden at Darjeeling, and to Mr. R. S. Pearson, Imperial Forest Economist at Dehra Dun, his keen appreciation of their courtesy in sending valuable material of Indian plants. To Dr. Jeffrey the writer is much indebted for material and kind assistance in the course of the investigation, and to Mr. James Austin for assistance in photomicrography. 


\title{
BIBLIOGRAPHY.
}

1. BAILey, I. W.: Relation of the Leaf-trace to the Formation of Compound Rays in the Lower Dicotyledons. Annals of Botany, vol. xxv, No. xcvii, January, I9I I.

2. - Reversionary Characters of Traumatic Oak Wood. Bot. Gaz., vol. 1, No. 5, Nov., 1910, pp. 374-80.

3. - Notes on the Wood Structure of the Betulaceae and Fagaceae. Forestry Quarterly, vol. viii, No. 2, I9I0.

4. Eames, A. J. : On the Origin of the Broad Ray in Quercus. Bot. Gaz., xlix, No. 3, March, igio.

5. $:$ On the Origin of the Herbaceons Habit in Angiosperms. Annals of Botany, vol. xxv, No. xcvii, Jan., I9II.

6. Groom, Percy: The Evolution of the Annual Ring and Medullary Rays of Quercus. Annals of Botany, vol. xxv, No. c, Oct., I9II.

7. Jefrrey, E. C. : The Comparative Anatomy and Phylogeny of the Coniferales. Part I. The Genus Sequoia. Mem. Boston Soc. Nat. Hist., vol. v, No. 10, pp. 44I-59, Pl. 68-7I.

8. Jost, L. : Ueber einige Eigenthümlichkeiten des Cambiums der Bänme. Botan. Zeitung, Bd. lix, p. I5.

9. Holden, Ruth : Reduction and Reversion in North American Salicales. Annals of Botany, vol. xxvi, No. ci, Jan., IgI 2.

10.

11. Stopes, M. C., and FujIr, K. : Studies on the Structure and Affinities of Cretaceous Plants. Phil. Trans. of the Royal Soc. of London, Series B, vol. cci, pp. I-90.

12. Thompson, W. P. : On the Origin of the Multiseriate Ray of the Dicotyledons. Annals of Botany, vol. xxv, No. c, Oct., I9I1.

\section{EXPLANATION OF PLATES LXII AND LXIII.}

\author{
Illustrating Mr. Bailey's paper on the Foliar Ray.
}

\section{PLATE LXII.}

Fig. I. Castanea dentata. Tangential section of the mature wood, showing the uniseriate rays. $\times 60$.

Fig. 2. Casuarina, sp. Transverse section of the mature stem, showing the depression in the outline of the xylem produced by an aggregate ray. $\times 20$.

Fig. 3. Castanopsis tribuloides. Transverse section of the mature stem, showing a small segment of wood which is depressed by two closely approximated foliar rays. $\quad \times 20$.

Fig. 4. Alnus mollis. Transverse section of a mature vigorous twig, showing numerous rays of the aggregate type in the first and second annual layers of growth. $\times 20$.

Fig. 5. Alnus yasha. Transverse section of the node of a mature twig, showing a welldeveloped aggregate ray in the vicinity of the leaf-trace. The ray is seen to die out in the third annual ring. $\times 20$.

Fig. 6. Castanea dentata. Transverse section of a vigorous mature root, showing the retention of aggregate rays. $\times 20$.

Fig. 7. Alnus yasha. Transverse section of a vigorous mature root, showing the retention of aggregate rays. $\times 20$.

Fig. 8. Alnus mollis. Transverse section of the mature stem in the vicinity of a severe injury, showing a large aggregate ray which has been recalled tranmatically. $\times 40$.

Fig. 9. Alnus mollis. Transverse section of the mature root, showing aggregate rays recalled by a severe injury. $\times 20$.

Fig. 10. Ostrya virginiana. Transverse section of an insect gall in a mature twig, showing the traumatic recurrence of an aggregate ray. The ray produces a sag in the outline of the xylem and is capped in the phloem by a dark-coloured cluster of sclerenchyma. $\times 100$. 
Fig. 11. Castanopsis tribuloides. Transverse section of the mature wood of the stem, showing the remains of a once strongly developed aggregate ray. $\times 60$.

Fig. 12. Castanopsis tribuloides. Transverse section of the mature root, showing evidence of the reduction of aggregate rays in the root. $\times 60$.

\section{PLATE LXIII.}

Fig. 13. Castanopsis tribuloides. Transverse section of a mature twig, showing the strongly depressed segments produced by well-developed approximated foliar rays. $\times$ Io.

Fig. I4. Castanopsis indica. Transverse section of a mature stem, showing the persistence of five well-developed depressed segments. $\times 10$.

Fig. 15. Quercus velutina. Transverse section of a mature twig, showing five small depressed segments which are produced by five pairs of closely approximated lateral leaf-trace rays. $\quad \times 20$.

Fig. 16. Castanopsis hystrix. Transverse section near the node of the mature twig, showing the persistence of two strongly depressed segments $(y)$ which are related to the lateral leaf-traces of this node. Indications of the three other depressed segments $(x)$ are more or less feebly developed. $\times$ ro.

Fig. 17. Castanea pumila. Transverse section of a vigorous mature twig, showing the retention of five depressed segments after the disappearance of the foliar rays. $\times 10$. 



\title{
REREDVE \\ SEP 231914 \\ Division of Fores \\ University of Califor
}

\section{TYLOSES: THEIR OCCURRENCE AND PRACTICAL SIGNIFICANCE IN SOME AMERICAN WOODS}

\author{
BY ELOISE GERRY, \\ Microscopist, Forest-Products Laboratory, Forest Service
}

\section{GENERAL DESCRIPTION OF TYLOSES}

The large open pores or vessels conspicuous in hardwoods frequently become closed by growths called tyloses. ${ }^{1}$ These growths render the wood practically impermeable to air and liquids. On the split surfaces of a wood such as white oak or pignut hickory the tyloses appear in the vessel channels as glistening cellular growths resembling masses of soap bubbles. (P1. LII, fig. I.) These masses are protrusions from the living parenchyma cells of the wood itself into adjacent vessel or tracheid cavities. They enter at the thin places or pits in the wall of the wood elements (see P1. LII, figs. 2 and 3), and expand to a greater or less degree. In the softwoods (P1. LVI, fig. I) tyloses are relatively small, but in the hardwoods they frequently form bladderlike sacs of considerable size (P1. LII, figs. 2 and 3 , and P1. LIII, figs. I, 2, and 3), often developing simultaneously in many of the parenchyma cells surrounding the tubelike vessel cavities. (P1. LII, fig. 3.) Under such circumstances, if growth is vigorous, the tylosal sacs, after pushing into the vessel cavity, grow together, completely filling it. In this way the ability of the vessel to conduct air or liquid is effectually checked. (P1. LIII, figs. I and 2.) Sometimes, however, the tylosal growths do not entirely fill the vessel, and only a clogging action results.

The purpose of this study was to determine the occurrence of tyloses in the most important commercial species of native woods and their significance in relation to the adaptability of these woods to certain practical uses.

Observations were made not only of the presence or absence of tyloses in a species, but also of the extent and degree of development and the regions (sapwood or heartwood) where the growths are found.

1 These growths received, in 1845 , the name "Thylle" (tyloses) from a German botanist who signed as "Ungenannte," or "unknown," the paper discussing them. This writer is, however, believed by Boehm and Winkler to have been Frl. Hermine von Reichenbach. The name "Thylle" is derived from the Greek word $\theta 0 \mu_{\text {es, }}$, meaning a purse or sack. The occurrence of tyloses was, however, noted as early as 1675 by Malphigi, in the drawing of a cross section of chestnut wood. They are also given the descriptive name "Füllzellen," or filling cells, by the Germans. 
Only a brief discussion is given of the causes leading to the formation of tyloses or of their function in the living plant, since studies for this purpose have already been made by other investigators.

\section{MORPHOLOGICAL RELATIONS OF TYLOSES IN WOODY TISSUE}

\section{ORIGIN AND DEVELOPMENT}

A tylose can not be considered as a distinct cell, for as a rule a cell is defined as a body consisting of cell substance, cell wall, and cell nucleus. With very rare exceptions (Molisch) ${ }^{1}$ a tylose, as found in woody tissue, is not completely surrounded by a wall and has no nucleus. It is only a portion oz prolongation of a wood or medullary-ray parenchyma cell. (P1. LII, figs. 2 and 3; P1. LVII, fig. 2.) Frequently more than one tylose is formed from one parenchyma cell, but only one active nucleus-that of the parenchyma cell-is present, though this may be found in one of the tyloses. (P1. LII, fig. 3.) A parenchyma cell which has given rise to two tyloses is shown in Plate LII, figure 2.

The growing or arching out of tyloses has been found to follow a reduction in internal pressure or cessation in sap conduction in the large vessels. When this occurs, the living parenchyma cells, which possess a considerable growth potential, expand and press into the adjacent empty vessel cavities. In pitted vessels this expansion is localized in the thin unlignified membranes of the one-sided bordered pits which are present on the dividing walls between vessels or tracheids, and parenchyma (De Bary; Green; Haberlandt; Hanausek; Molisch; Rees; Russow; Sachs; Strasburger; and Winckler). These membranes contain plasma and therefore possess the power of growth. The internal pressure of the turgid parenchyma cells, when exerted against these relatively thin spots or pits, causes the pit membranes to stretch and grow by intussusception ${ }^{2}$ (Green; Molisch). The protrusions increase gradually in size and finally develop into the characteristic bladder-shaped sacs known as tyloses. An open passage through the space previously occupied by the unstretched closing membrane of the pit is formed in this way between the tylose and the parenchyma cell. (P1. LII, fig. 2.) The contents of the tylose are therefore the same as those of the parenchyma cell.

\section{NORMAL AND ABNORMAL TYLOSE FORMATION}

It has been shown beyond doubt that the wounding of trees through cuts or bruises or at the points where branches are broken off tends to stimulate tylose formation, and throughout the study this mode of tylose formation has been constantly borne in mind. Generally, however, tyloses are not due to wounding. They are a characteristic feature of the normal uninjured wood of many families of trees. Nevertheless,

\footnotetext{
1 Bibliographic citations in parentheses refer to "Literature cited," pp. 468-469.

2 "Intussusception" means in botany, according to Nagëli, the growth of cell walls by the irregular interposition of new solid particles between those already in existence.
} 
the wood produced by felling the tree may have an important bearing on the presence of tyloses in the outer rings of a log, where the parenchyma cells are still living and capable of growth. It is possible to find in these rings young or old, or large and small, tyloses together in the same vessel. (P1. LIV , R3.) Although exceptions have been noted, the idea that a considerable number of the outer rings are entirely free from tyloses has, however, been very generally accepted (Strasburger). ${ }^{1}$ The data obtained from the present study show that there is a very considerable formation of tyloses in the outer rings of the sapwood. The question then arose as to whether these sapwood tyloses were of normal origin or whether they were due to some wound stimulus, such as the felling of the tree. It was finally concluded that they were normally formed tyloses, because their development throughout the vessels was very uniform instead of being sporadic or irregular, as in the case of tyloses associated with wounds (P1. LIV, $R I$ and $R 2$ ), and because an examination of branches from living trees of Rhus, the sumach, Catalpa, and Robinia, the black locust, made immediately after cutting, confirmed the other observations of the relatively early formation of tyloses in many species. In material which was not received for examination until several weeks after it was cut, thin, irregularly distributed tyloses were often found in the outer vessels, though the latter must have been functioning in sap condition at the time the tree was felled.

It is noteworthy also that in this study tyloses were found to reach the most remarkable development in ring-porous woods, such as oak, hickory, black locust, or osage orange. (P1. LIII, figs. I and 3, and P1. LVI, fig. 2.) In woods where tyloses are few and scattered there is considerable variation from specimen to specimen in the actual number of tyloses present. This tendency is clearly shown in the woods of the diffuse porous group. (Table II.) It is also noticeable that in the two or three rings surrounding the pith in a diffuse porous wood tyloses are often much more abundant than elsewhere in either the heartwood or sapwood.

\section{EFFECT OF THE DISTRIBUTION OF PARENCHYMA TISSUE}

Since tylose formation depends upon the presence of parenchyma cells either in the form of wood parenchyma or medullary rays in close proximity to vessels or tracheids, the variation in position, abundance, and vitality of these cells affords at least a partial explanation of the irregular development of tyloses in different species of wood. Parenchyma tissue is considerably developed in the following families and their respective genera. ${ }^{2}$ This study has shown that in these families are a large number of native woods exhibiting tyloses.

\footnotetext{
1 Tyloses are ... instrumental in closing the water courses of the heartwood. . . . These are intrusive growths from living cells which penetrate the cavities of the adjoining tracheal elements during the transition of sapwood into heartwood.

${ }^{2}$ Solereder, Hans. Systematic Anatomy of the Dicotyledons . . v. v, p. 1r43. Oxford, rgo8. Certain other woods with abundant parenchyma frequently produce gummy substances rather than tyloses.
} 
Family.

Genera.

Cupuliferæ or Fagaceæ..........................

Juglandaceæ.................................. Juglans.

Papilionaceæ...................... Robinia.

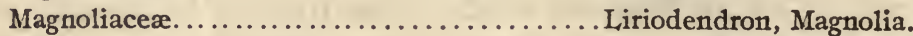

Moraceæ............................... Toxylon.

The arrangement of wood parenchyma cells in the annual ring has been divided ${ }^{1}$ into three different types, as follows:

r. Terminal parenchyma, which is situated at the periphery of the annual growth ring, on the outer face of the summer wood.

2. Metatracheal or diffuse parenchyma, which is scattered among the other elements in the ring, usually forming tengential bands.

3. Paratracheal or vasicentric parenchyma, or parenchyma cells, aggregated around the vessels.

TABLE I.-Native woods grouped according to the degree of tylose development and the most marked distribution of wood parenchyma in ring. ${ }^{2}$

ABUNDANT TYLOSES. ${ }^{3}$

\begin{tabular}{|c|c|c|c|}
\hline Species. & $\begin{array}{c}\text { Type of } \\
\text { parenchyma. }\end{array}$ & Species. & $\begin{array}{c}\text { Type of } \\
\text { parenchyma. }\end{array}$ \\
\hline 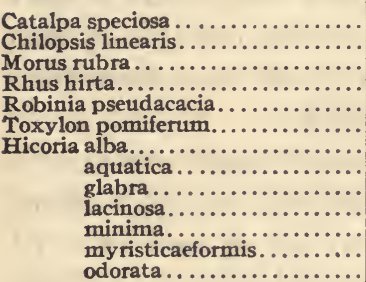 & $\begin{array}{l}\text { Paratracheal. } \\
\text { Do. } \\
\text { Do. } \\
\text { Do. } \\
\text { Do. } \\
\text { Do. } \\
\text { Do. } \\
\text { Do. } \\
\text { Do. } \\
\text { Do. } \\
\text { Do. } \\
\text { Do. } \\
\text { Do. }\end{array}$ & 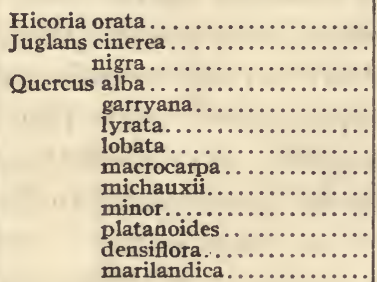 & $\begin{array}{l}\text { Paratracheal. } \\
\text { Do. } \\
\text { Do. } \\
\text { Do. } \\
\text { Do. } \\
\text { Do. } \\
\text { Do. } \\
\text { Do. } \\
\text { Do. } \\
\text { Do. } \\
\text { Do. } \\
\text { Do. } \\
\text { Do. }\end{array}$ \\
\hline
\end{tabular}

MaNy Trloses.

\begin{tabular}{|c|c|c|c|}
\hline 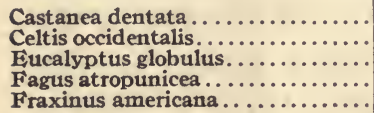 & $\begin{array}{l}\text { Metatracheal. } \\
\text { Paratracheal. } \\
\text { Do. } \\
\text { Metatracheal. } \\
\text { Paratracheal. }\end{array}$ & 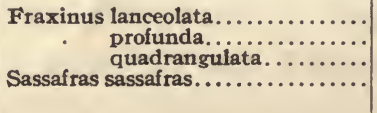 & $\begin{array}{l}\text { Paratracheal. } \\
\text { Do. } \\
\text { Do. } \\
\text { Do. }\end{array}$ \\
\hline
\end{tabular}

SCATTERED TYLOSES.

\begin{tabular}{|c|c|c|c|}
\hline 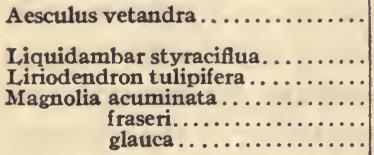 & $\begin{array}{l}\text { Scanty para- } \\
\text { tracheal. } \\
\text { Metatracheal. } \\
\text { Terminal. } \\
\text { Do. } \\
\text { Do. } \\
\text { Do. }\end{array}$ & 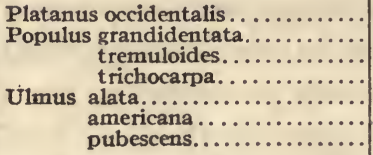 & $\begin{array}{l}\text { Metatracheal. } \\
\text { Terminal. } \\
\text { Do. } \\
\text { Do. } \\
\text { Paratracheal. } \\
\text { Do. } \\
\text { Do. }\end{array}$ \\
\hline
\end{tabular}

1 Jeffrey, E. C. A Natural Classification of Woods.

Holden, Ruth. Some features in the anatomy of the Sapindales. In Bot. Gaz., v. 53, no. I, p. 50-58, pl. $2-3$. I912.

2 The data here given concerning the distribution of parenchyma were obtained from: ( $r$ ) Solereder, Hans, op. cit.; (2) Jeff rey, E. C., op. cit.; and (3) from original observations made during the study.

${ }^{8} \mathrm{By}$ "abundant" is meant a very large number. "Many" is used to signify a considerable number but less than "abundant." 
These three types of arrangement and the degree of their development bear a definite relation to the development of tyloses, since they indicate whether the parenchyma cells are near enough to the vessel cavities to send their prolongations into them. In addition to the wood parenchyma, the position and number of the medullary rays adjacent to the vessels must be taken into account. A grouping of the species of wood with the twofold object of indicating the distribution of tyloses and the arrangement of the wood parenchyma clearly brings out some of the reasons why tyloses are so much more abundant in certain woods than in others. Wherever the paratracheal or vasicentric type of parenchyma is well developed, the tendency for marked tylose formation, or else for gum production, is very noticeable. From Table $I$ it is further evident that when tyloses are strongly developed either paratracheal or abundant metatracheal parenchyma is always found.

\section{SHAPE, THICKNESS OF WALL, AND CONTENTS OF TYLOSES}

The shape of the tylosal projections varies widely. They are sometimes spherical, or again they appear as elongated vesicles. (P1. LII, fig. 3; and P1. LIII, figs. I, 2, and 3.) Often when the walls are very thin they appear much collapsed and wrinkled as, for instance, in ash or the wound tyloses in cow oak. (P1. LIV, RI.) The extent to which the tylose wall increases in thickness varies also. The wall may be an extremely thin delicate membrane as found in ash or osage orange (P1. LV, fig. 2) or it may be of medium thickness as in oak. (P1. LIII, figs. I and 2.)

The contents of the tyloses are in general the same as those of the parenchyma cells producing them. Starch is common, and resin, calcium crystals, and gums have also been observed.

When normal parenchyma cells do not give rise to tyloses, the so-called "gums" (Prael) ${ }^{1}$ are often produced, as in mesquite, maple, or cherry. This gum usually collects in the vessels (P1. LIII, fig. 4) and parenchyma cells. In the vessels it sometimes assumes the form of globules or droplets which may easily be mistaken for tyloses. In order to determine whether gum or tyloses are present, a section of the wood may be treated with some gum solvent, such as absolute alcohol or caustic soda. When the wood is dry, the gum droplets are often characteristically cracked and split. Their general appearance is illustrated in Plate LIII, figure 4.

\section{MATERIAL AND METHODS USED IN THE STUDY}

The material used for this study of tyloses was a collection of logs of commercial size from native-grown trees. As a basis for the study of tyloses this material was unique, since most of the work of other investigators has been done not on wood from the bole of the tree, but on 
branches, twigs, roots, leaves, vines, herbaceous plants like the squash, or on such of the lower forms as ferns, ${ }^{1}$ and did not cover to any extent the American species.

The method of examining the wood was as follows: The ends of the logs which form the collection of commercial American woods (P1. LIX, fig. I) of the Forest-Products Laboratory were examined with a hand lens. Blocks cut from these were also studied microscopically. Small strips extending from the bark through the trees to the pith, including the sapwood, the so-called transition region, and the heartwood, ${ }^{2}$ were cut from the logs. Microtome sections about I inch by one-half inch in area and 5 to 20 micromillimeters in thickness were cut from the three planes, transverse, radial, and tangential, taken from each of these different regions and were studied under the compound microscope. The observations for hardwoods are given in Table II. Stains were often employed to differentiate the tissues, and macerations were made with potassium hydroxide or chromic acid for special studies of the relations between the tylose and the parenchyma cell producing it. Fresh material from seedlings and branches was also examined, in order to determine whether the sapwood tyloses were of normal or abnormal origin.

The Forest-Products Laboratory collection of woods begun in I9ro is not yet complete, and in many cases only one log of a species was available for study. Nevertheless, the majority of the commercially important species are included in the laboratory collection, and in addition to the study of these it was possible to make further observations on authentic material of a number of other important species. Moreover, whenever two or more specimens of the same species were examined, results were

1 This list of the plant genera where tyloses have been found in wood, roots, leaves, or other portions is given by Küster. It includes Molisch's observations on the Vienna wood collection and other material as well as those of other authors, whose names are given in parentheses after the genera they investigated,

Abies (Raatz).

Achyranthes.

A esculus (Maiile, Tison).

Alnus (Tison).

Ampelopsis.

Aralia.

A ristolochia (Tison).

Artocarpus.

Arundo.

Asarum.

Banisteria.

Begonia.

Betula.

Bigonia.

Boehmeria.

Broussonetia.

Byrouia.

Canna.

Carica.

Carya.

Cassis.

Castanea.

Catalpa.

Celtis.

Chiliantus.

Coccoloba.

Convolvulus (Dutailly). L,oranthus.

Cornus (Maüle). Ioxapteryguim.

Corypha.

Cucumis.

Cucurbita.

Cuspidaria.

Dahlia.

Diospyros.

Elaeagnus.

Euphorbia.

Fagus.

Ficus.

Fraxinus.

Gleditsia (Tison)

Hammamelis (Tison).

Hedera.

Hedychuim.

Heliconia.

Humulus ('Tubeuf).

Inula.

Jatropha.

Juglans.

Koelreuteria.

L,atania.

Machura.

Mansoa.

Maranta.

Micania.

Morus.

Musa.

Ochroma.

Olea.

Ostrya.

Passiflora.

Paulownia.

Perilla.

Philodendron.

Phyllanthus.

Picea (Raatz).

Pinus (Raatz).

Piratinera.

Pistacia.

Plantago.

Platanus.

Portulacca.
Prunus (Wieler).
Pterocarya.
Quercus.
Rhus.
Ricinus.
Robinia.
Rosa (Maüle).
Rubia.
Rumex (Dutailly).
Salix.
Sambucus.
Santalum.
Schinus.
Sideroxylum.
Solanum.
Sparmannia.
Strelitzia.
Styinatophyllum.
Taraxacum.
Thunbergia.
Ulmus.
Urtica.
Vitis.
Xanthoxylon (Tison).

2 The cross section of a mature tree may be divided into at least two regions: The outer or last-formed rings, variable in number, which are termed the "sapwood" or "alburnum," and the inner rings around the pith or center of the tree, which in dry material are sometimes indistinguishable in appearance from sapwood, but which are more often definitely marked by a difference in color and are then termed the "heartwood" or "duramen." (PI. L,IX, fig. I.) 
found to check reasonably well, as shown in Table II. The greatest variation occurs in the species in which tyloses are very rare or else scatteringly developed and, therefore, where their practical importance is relatively slight.

\section{OCCURRENCE OF TYLOSES IN NATIVE HARDWOODS}

Table II gives the results of observations made on the distribution and region of first development of tyloses in 143 specimens of hardwoods grown in the United States. The very marked development of tyloses in certain species has been noted in Table I.

Special attention was given to the early development of tyloses. The results show their presence in the sapwood of all the species in which they occur in the heartwood. The hickories, for instance, give some interesting data concerning the occurrence of tyloses in sapwood. It has been maintained that if tyloses ever occurred in sapwood they would be found only in very narrow sapwood - that is, where the transition from sap to heartwood begins at the end of the first or second year after the ring is formed, as, for instance, in some of the oaks. In the hickories, however, tyloses are always present in the sapwood, and are generally developed even in the outermost rings as abundantly as in the heartwood. Plate LIII, figure 3 , shows a cross section of the sapwood of pignut hickory (Hicoria glabra), including the fourth to the seventh rings in from the bark. This particular tree had $3 \mathrm{I}$ rings of sap, or uncolored wood, and tyloses were well developed in the very outermost rings. (P1. LIX, fig. I.)

Tyloses are normally lacking in the red-oak group, although there are many exceptions. An illustration of vessels not filled by tyloses is given by those in the middle of Plate LIV,$R_{2}$, and by some of those in Plate $\mathrm{LV}$, figure I. In some cases tyloses occur in individual vessels in species ordinarily free from them, as Spanish oak. (Table II.) In several instances the few scattered tyloses present in both the sapwood and heartwood have a rather abnormal appearance and are associated with areas of fungous growth. (Table II, Scarlet oak.) In certain species of the redoak group, however, as blackjack oak (Quercus marilandica), tyloses are very generally developed in both the sapwood and heartwood.

In the white oaks, in contrast to the red-oak group, tyloses are generally very abundant, even in the outermost rings. Some of the white oaks where tyloses are slow in forming show striking examples of the growth and development of the tylose in its early stages. This is illustrated in Plate LII, figure 3 , which is a reproduction of. a photomicrograph of a cross section of California white oak, or valley oak (Quercus lobata), showing a piece of the sapwood next to the bark. Fragments of the bark may be seen at the top of the illustration. The relatively small bladderlike cells here shown increase in size until they grow together and fill the vessels as shown at the bottom of this illustration and in Plates LIII, figures 1,2 , and 3 , and LV, figure 2 . 


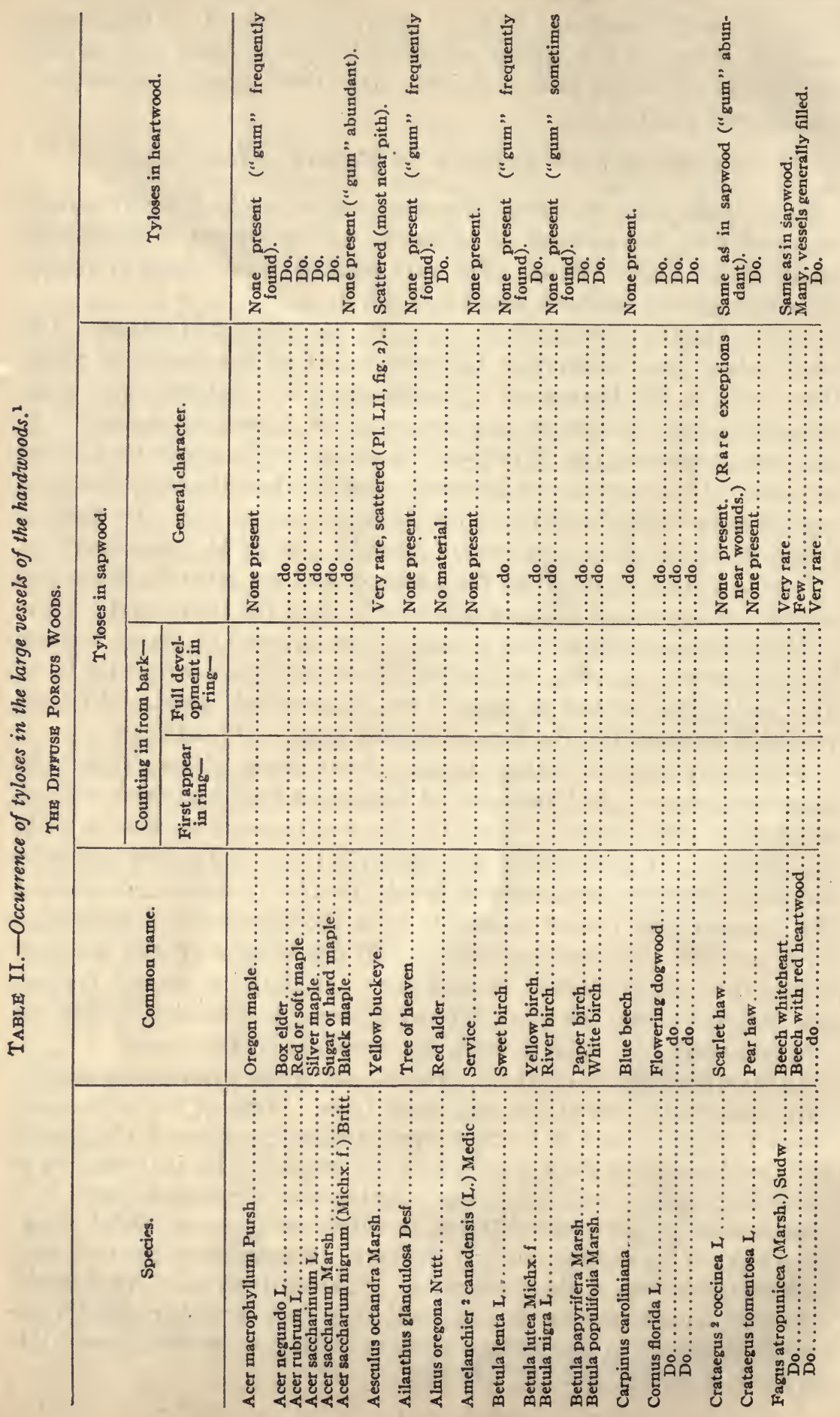




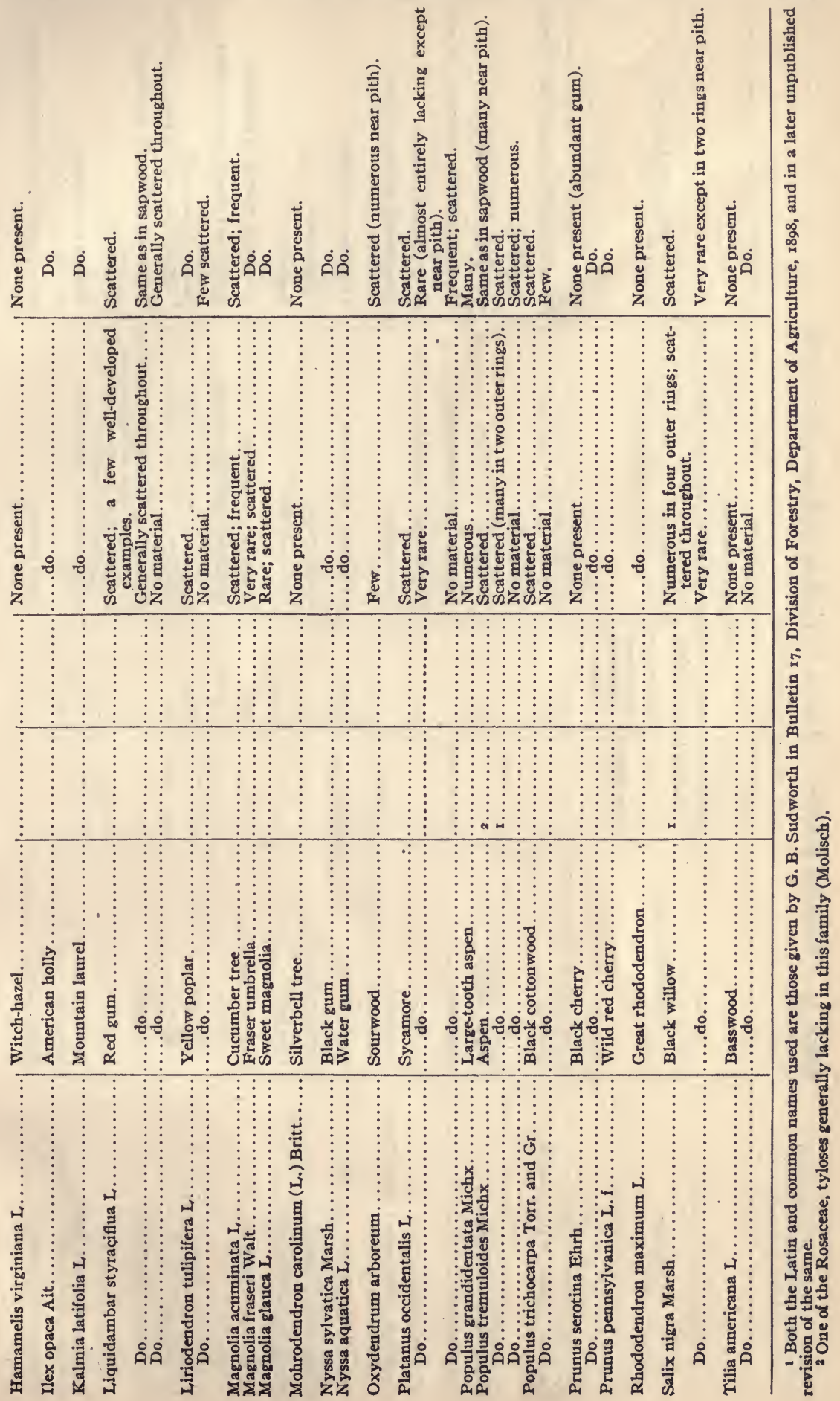




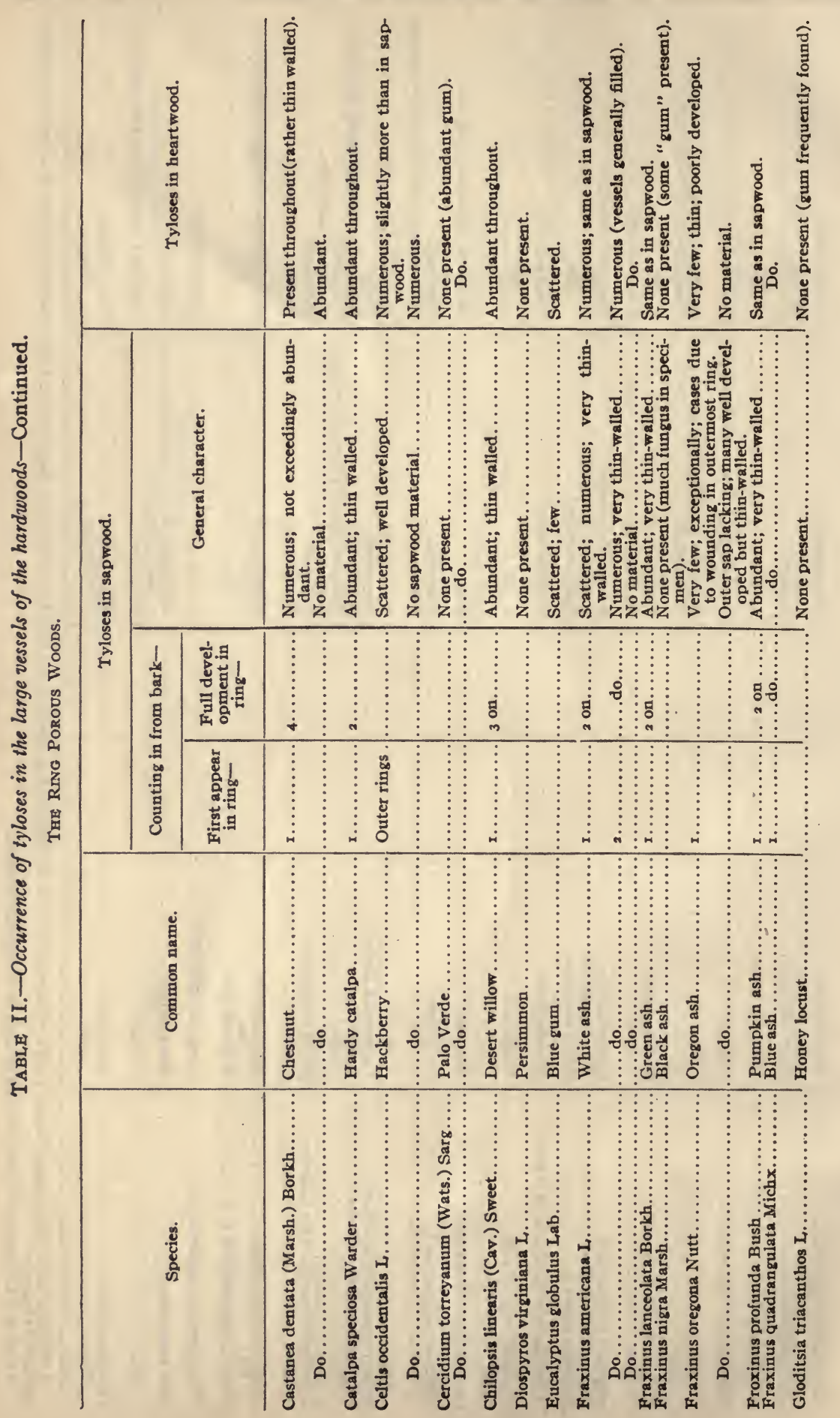




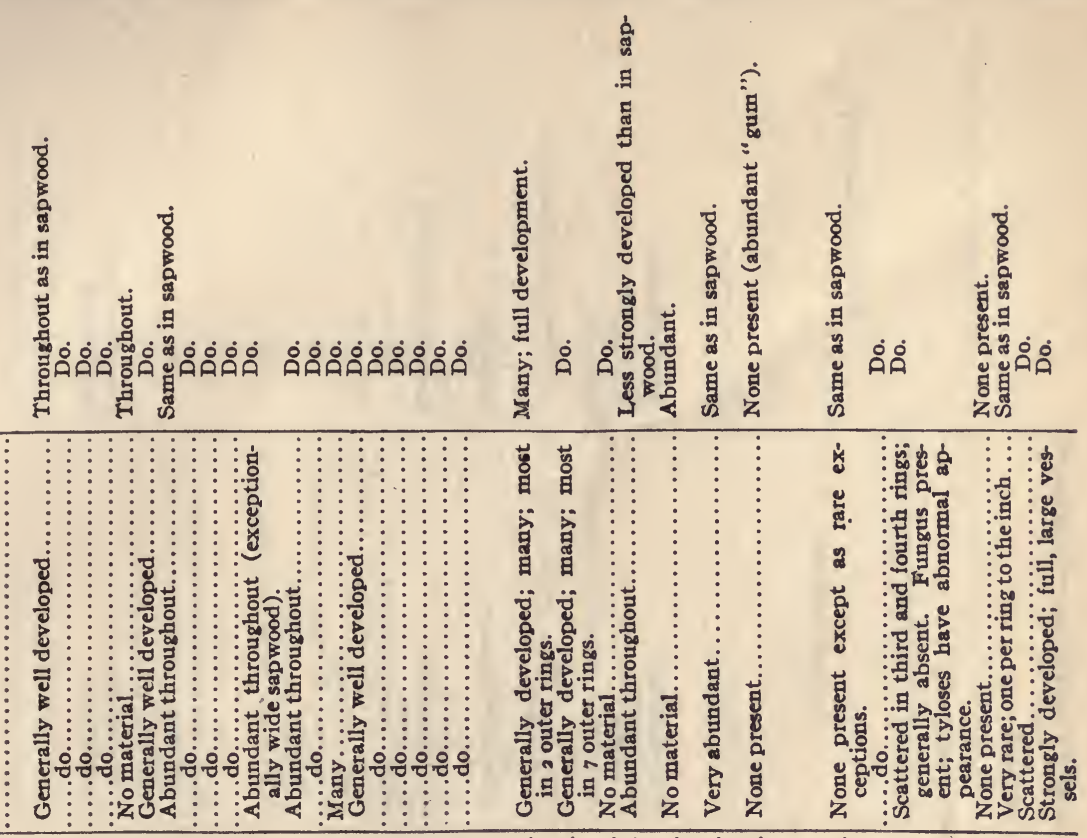

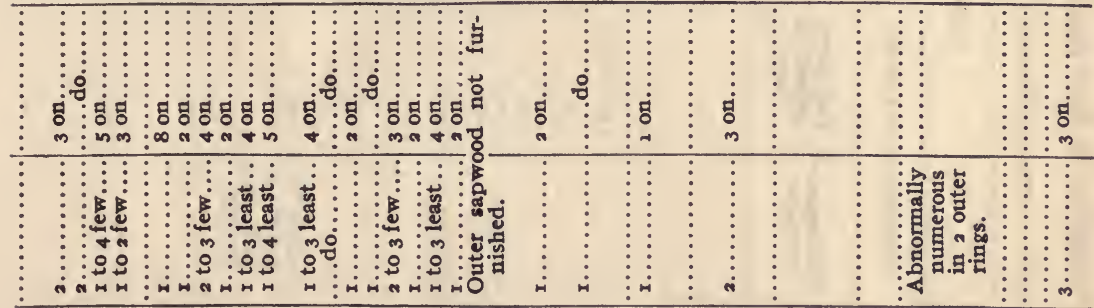

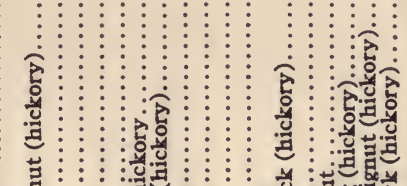

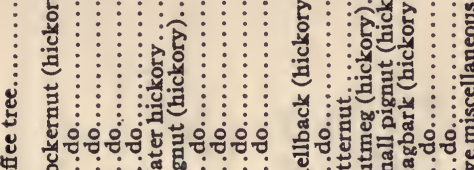

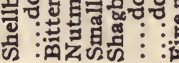

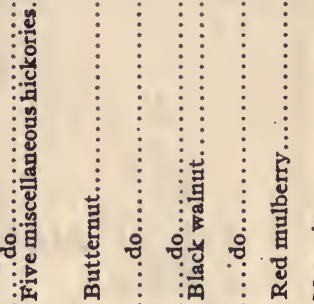

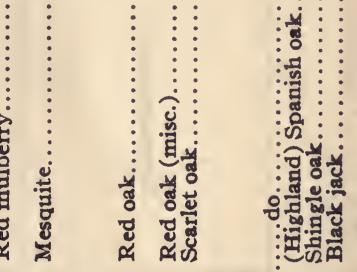

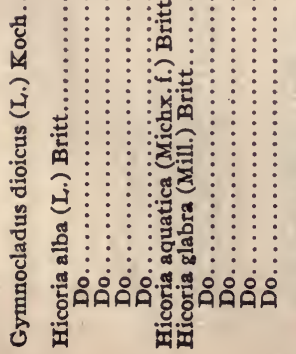

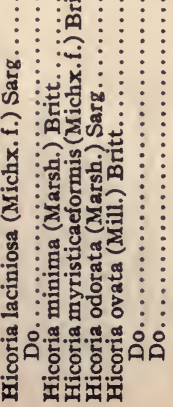

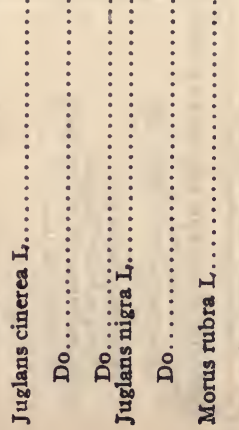

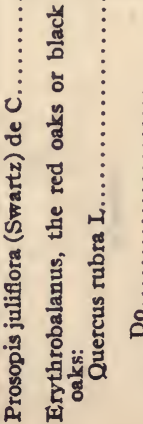

: 


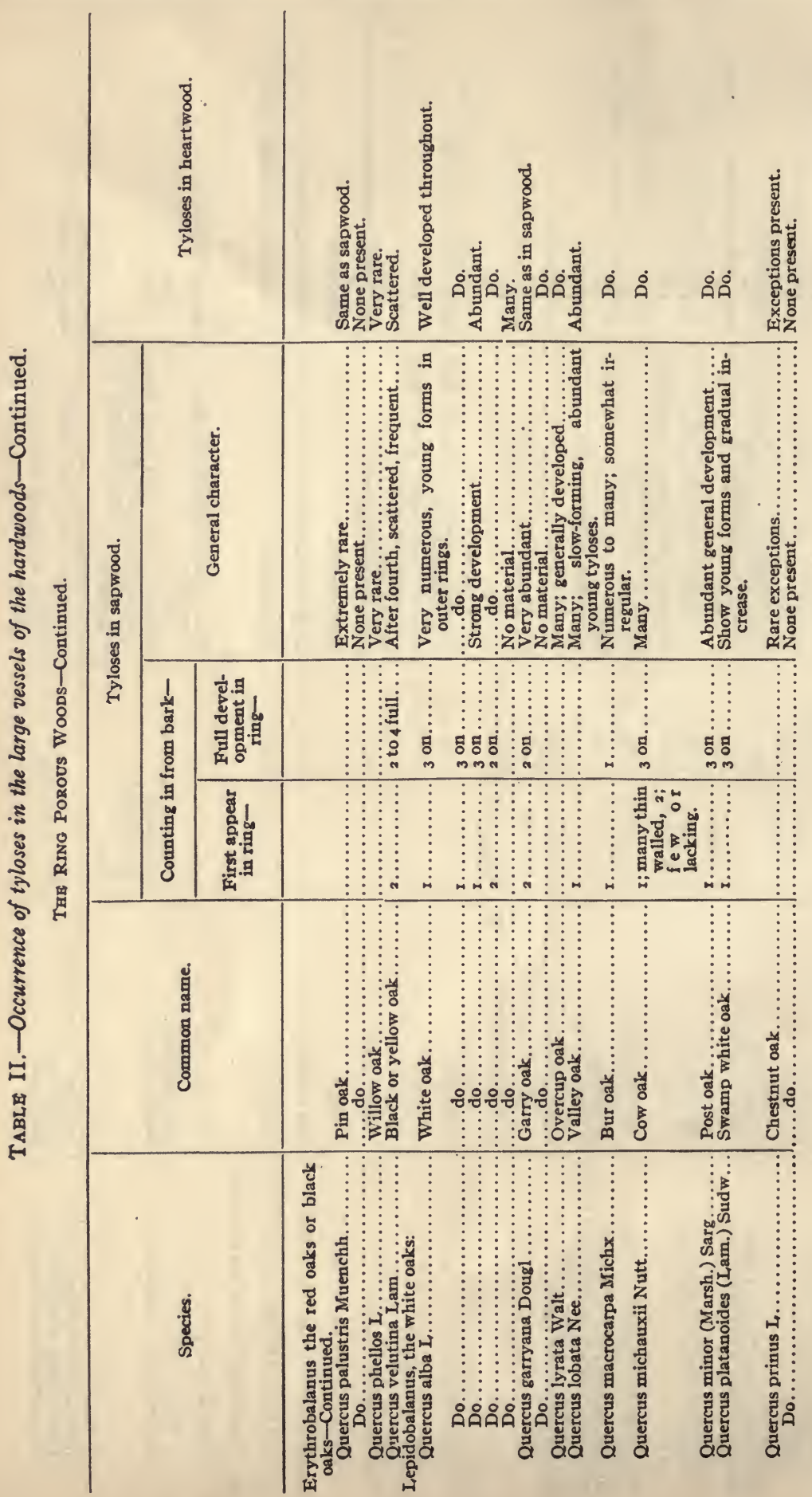




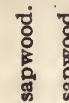

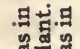

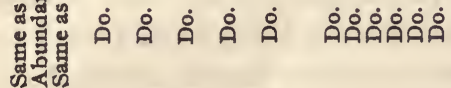
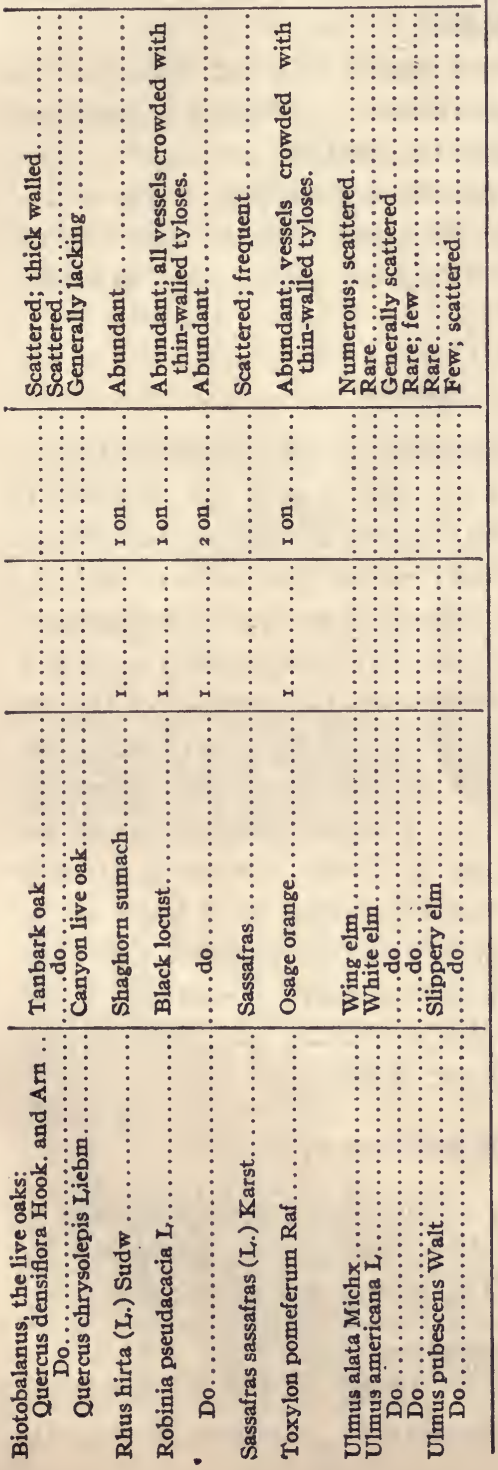


\section{TYLOSES IN SOFTWOODS}

Coniferous or softwoods lack the large open pores or vessels which characterize the hardwoods. They also either lack or show a scanty development of wood parenchyma, the chief source of tylose formation in the hardwoods. Since it is in relation to the closing of the vessels that tyloses are of practical significance, the study of tylose distribution in the conifers is of relatively small importance. However, since tyloses or tyloselike cells are often present in the tracheids or in the resin canals of certain normal coniferous woods, and since they have been found to play some part in penetration of wood preservatives and in resin flow, their occurrence in the softwoods was studied.

The occurrence of tyloses in coniferous woods has not received the attention given to their occurrence in hardwoods. Often their presence has been ignored, or they have been reported as entirely lacking. ${ }^{1}$ When studied, moreover, investigations were usually confined to parts of the plant other than the wood, ${ }^{2}$ though there are a few notable observations on their occurrence in the wood itself (Boehm; Chrysler; Conwentz; Küster; Mayr; Penhallow; Raatz).

\section{TRUE TYLOSES IN CONIFERS}

Tyloses in normal coniferous wood arise chiefly from the parenchymatous cells of the medullary rays. (P1. LVI, figs. I and 2.) As in the hardwoods, it is by the growth of the membranes of the one-sided bordered pits that tyloses are formed, especially where the pits are of large size, as in the white pines. In this case tyloses grow into the lumen of the tracheid, just as in hardwoods they grow into the vessels or pores. Tracheids, like vessels, function as sap conductors, but instead of having in their end walls actual openings of considerable size they have only relatively thin regions or pits. These are more or less completely closed by an irregularly thickened membrane, portions of which sometimes contain very minute perforations (Bailey). Thus in these elements already closed or nearly closed, tyloses have not the effect that they have in the open vessels of the hardwoods. Moreover, tylose formation of this type in conifers can only take place in a comparatively small percentage of the tracheids-that is, in those adjacent to the medullary-ray parenchyma cells produced as a result of wounds (Boehm; Raatz). ${ }^{3}$

\section{TYLOSELIKE CELLS IN THE RESIN CANALS}

Aside from true tyloses, there is often observed in certain species of conifers a partial or complete closing of the resin canals, produced by parenchyma cells, but not by growth of the membrane of the one-sided

1 Reported by Molisch after examining 700 species of plants of all sorts.

2 They are said to be more abundant in the root than in the stem (Raatz). They also have been studied in the leaf and in the cone axis.

Boehm and Raatz observed tyloses as a result of wounding in Abies pectinata, Pinus sylvestris, Pinus sirobus, Pinus excelsa, Larix europea, and Thuja occidentalis. 
bordered pit. Such growths are termed "tyloselike," since they produce an effect very similar to that produced by the true tyloses of the hardwoods.

Resin canals or ducts are normally present in the following coniferous genera: Larch, or tamarack (Larix), spruce (Picea), Douglas fir (Pseudotsuga), and pine (Pinus). These canals when seen in cross section often bear a superficial resemblance to the vessels or pores of the hardwoods. (P1. LVII, fig. I.) They are, however, different in both their origin and function. Resin ducts are not cellular elements, but simply intercellular spaces which result from the splitting apart of the common walls of a group of parenchyma cells. A very early stage of this splitting is shown in Plate LVI, figure $\mathrm{I}$. These parenchyma cells which surround the canal opening are called "epithelial cells." They are the seat of resin formation, and they cause the tyloselike closing of the resin canal. Certain of them often remain thin walled and contain plasma. (P1. LVIII, figs. 2 and 5.) After they split apart to form the canal, when they change in shape and size, a further swelling and growth may take place which closes the canal entirely or in part. (Pls. LVII, figs. I and 2, and LVIII, figs. 2, 5, and 6.) The fact that it is the growth or expansion of the whole cell, and not a portion of the wall of that cell, together with a portion of the wall of the neighboring cell, as in the tylose-forming membrane of the one-sided bordered pits of the hardwoods, clearly indicates the difference between the true tyloses of the hardwoods and the tyloselike cells in the resin canals of the conifers.

\section{OCCURRENCE OF TYLOSES AND TYLOSELIKE CELIS IN NATIVE CONIFERS}

Over 600 permanently mounted sections from coniferous woods in the collection of the Forest-Products Laboratory were specially studied, while more than three times this number were examined unmounted.

\section{TRUE TYLOSES}

Ray or true tyloses were found in the normal wood of the conifers, but were not abundant. Their shape and general appearance are well illustrated in Plate LVI, figures $I$ and 2. None of the long, saclike vesicles which sometimes fill the whole tracheid lumen in the roots of conifers were found. The greatest development of true tyloses was found in the soft pines. In this group they were better developed in spring wood than in summer wood and were more numerous in the sapwood than in the heartwood. Indeed, some of the pit membranes in the heartwood were concave in shape, appearing to have collapsed inward instead of protruding into the tracheid.

The size of the pits between the medullary ray cells and the tracheids in conifers bears a definite relation to the formation of tyloses. As a rule, the ray pits in the hard pines are small and tyloses are lacking, 
Norway pine (Pinus resinosa), which is regarded as a hard or pitch pine, offers an exception to this. Here we find numerous tyloses, but here also we have large ray pits. The only soft pine examined which did not contain tyloses was piñon pine (Pinus edulis). This species is characterized by small ray pits instead of the large ones common to this group.

Of the other conifers all of the species listed below have small ray pits. No true tyloses were found in these species. (See Table III.)

TABLE III.-Occurrence of true tyloses in native conifers.

SOFT PINES.

\begin{tabular}{|c|c|c|c|}
\hline Species. & $\begin{array}{l}\text { Number } \\
\text { of speci- } \\
\text { mens. }\end{array}$ & Sapwood. & Heartwood. \\
\hline 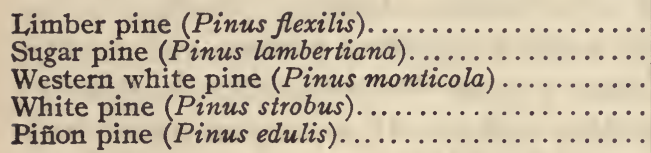 & $\begin{array}{l}I \\
I \\
I \\
2 \\
I\end{array}$ & $\begin{array}{l}\text { Abundant.. } \\
\ldots \text { do......... } \\
\text { Nume...... } \\
\text { None....... }\end{array}$ & $\begin{array}{l}\text { Numerous. } \\
\text { Do. } \\
\text { Do. } \\
\text { None. }\end{array}$ \\
\hline
\end{tabular}

HARd Pines.

\begin{tabular}{|c|c|c|c|}
\hline 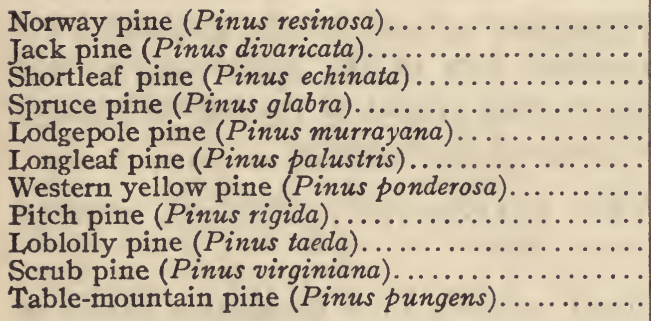 & $\begin{array}{l}2 \\
\text { I } \\
3 \\
\text { I } \\
\text { I } \\
\text { I } \\
2 \\
\text { I } \\
\text { I } \\
\text { I } \\
\text { I }\end{array}$ & 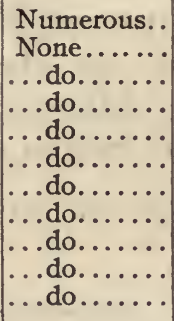 & $\begin{array}{l}\text { Numerous. } \\
\text { None. } \\
\text { Do. } \\
\text { Do. } \\
\text { Do. } \\
\text { Do. } \\
\text { Do. } \\
\text { Do. } \\
\text { Do. } \\
\text { Do. } \\
\text { Do. }\end{array}$ \\
\hline
\end{tabular}

OTHER CONIFERS.

Tamarack (Larix laricina)

Western larch (Larix occidentalis).

European larch (Larix larix)

White spruce (Picea canadensis).

Engelmann spruce (Picea engelmanni).

Black spruce (Picea mariana)

Sitka spruce (Picea sitche...

Douglas fir (Pseudotsuga taxifolia)

Balsam fir (Abies balsamea)

White fir (Abies concolor).

Alpine fir (Abies lasiocarpa).

Red fir (Abies magnifica).

Noble fir (Abies nobilis).

Port Orford cedar (Chamaecyparis lawsonia) .

Yellow cedar (Chamaecyparis nootkatensis).

California juniper (Juniperus californica)

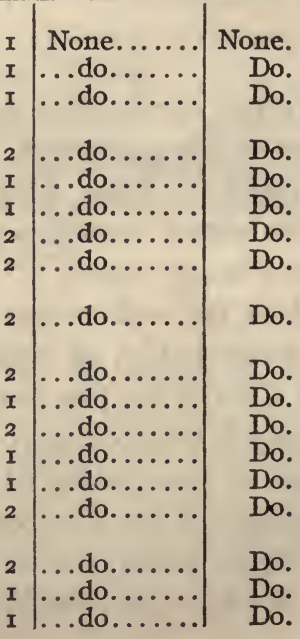


TABLE III.-Occurrence of true tyloses in native conifers-Continued.

OTHER CONIFERS-Continued.

\begin{tabular}{|c|c|c|c|}
\hline Species. & $\begin{array}{l}\text { Number } \\
\text { of speci- } \\
\text { mens. }\end{array}$ & Sapwood. & Heartwood. \\
\hline 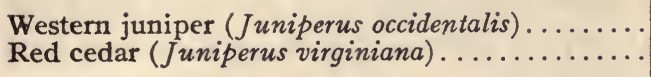 & $\begin{array}{l}\text { I } \\
\text { I }\end{array}$ & $\begin{array}{l}\text { None...... } \\
\text {...do....... }\end{array}$ & $\begin{array}{l}\text { None. } \\
\text { Do. }\end{array}$ \\
\hline Incense cedar (Libocedrus decurrens)............ & 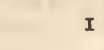 & ...do...... & Do. \\
\hline 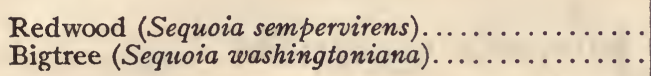 & $\begin{array}{l}\mathbf{I} \\
\mathbf{I}\end{array}$ & $\begin{array}{l}\ldots \text { do..... } \\
\ldots \text { do.... }\end{array}$ & $\begin{array}{l}\text { Do. } \\
\text { Do. }\end{array}$ \\
\hline Bald cypress (Taxodium distichum)...... & I & ...do.... & Do. \\
\hline Yew (Taxus brevifolia)...$\ldots \ldots \ldots \ldots \ldots \ldots$ & I & ...do...... & Do. \\
\hline 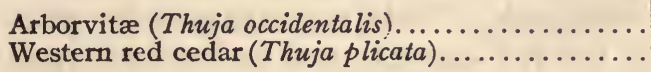 & $\begin{array}{l}\mathbf{I} \\
\mathbf{I}\end{array}$ & ... do.... & $\begin{array}{l}\text { Do. } \\
\text { Do. }\end{array}$ \\
\hline $\begin{array}{l}\text { Eastern hemlock (Tsuga canadensis) } \ldots \ldots \ldots \ldots \ldots \\
\text { Western hemlock (T suga heterphylla }) \ldots \ldots \ldots \ldots \ldots \\
\text { Black hemlock (Tsuga mertensiana }) \ldots \ldots \ldots \ldots\end{array}$ & $\begin{array}{l}\text { I } \\
2 \\
\text { I }\end{array}$ & $\begin{array}{l}\ldots \text { do } \ldots \ldots \\
\ldots \text { do........ } \\
\ldots \text { do..... }\end{array}$ & $\begin{array}{l}\text { Do. } \\
\text { Do. } \\
\text { Do. }\end{array}$ \\
\hline
\end{tabular}

TYLOSELIKE CELLS

The tyloselike epithelial cells which surround the resin canals were also carefully studied in Pinus, Larix, Picea, and Pseudotsuga. In these woóds both the horizontal and vertical resin canals often contained distended cells which partly or sometimes completely filled the canal openings. (P1. LVII, fig. 2; and P1. LVIII, figs. 2, 5, and 6.) This closed condition of the vertical canals is particularly noticeable near the medullary rays. (P1. LVI, fig. I ; and P1. LVII, fig. 2.) The distended closing cells correspond to the plasma-containing cells described on page 446. (P1. LVIII, figs. 2 and 5.) A large number of the canals were, however, entirely open.

In pines where many of the epithelial cells remain capable of growth, three types of conditions may be found in the canals.

(I) The canals of the sapwood, especially of the outermost ring, may not have yet opened-that is, the space which the canal will occupy may still be filled by the parenchyma cells which later form the epithelium. (P1. LVI, fig. I.)

(2) Many canals may be partly open. (P1. LVII, fig. I.) Frequently the cells surrounding the opening are somewhat contracted and collapsed; or, again, individual cells containing plasma may become distended, bow out into the open lumen of the canal, and thus assist in partially closing it.

(3) Canals in the heartwood as well as in the outer rings of the sapwood may be completely closed. ${ }^{1}$ This may come about in two ways: First, the groups of parenchyma cells observed in the sapwood may 
never have split apart to form a canal opening. This was demonstrated by the writer by means of serial sections following the course of a number of horizontal resin canals from the bark into the heartwood. Second, the canals once open may be closed completely by the growth of certain of the epithelial cells, as before explained. This closing is not produced by the equal action of all the cells which first split apart to form the canal, but only by the later growth of certain of these which possessed plasma and the growth potential for a longer period than their neighbors. (P1. LVIII, fig. 5.) ${ }^{1}$

\section{PRACTICAL, SIGNIFICANCE OF TYLOSES}

TYLOSES AS A NATURAL "FILLER"

A good instance of the part played by tyloses in the structure of wood is in the case of red oak and white oak. These two species have practically the same structure, yet the red oak can not be used for tight cooperage stock because the vessels are open tubes through which air or liquid can escape. (P1. LIV, middle.) In white oak the vessels are completely closed by tyloses, as shown in Plate LIII, figures I and 2, or Plate LIV, $R_{3}$.

In cabinetmaker's parlance, tyloses behave to some extent like a natural "filler." On a radial-cut surface the large vessels in the spring wood of a red oak appear like hollow grooves, while those in the white oaks are partly filled by the network of the tylosal cells which catch and hold paint, for example. (P1. LII, fig. I ; and P1. LIII, fig. 2.)

\section{TYLOSES A FACTOR IN DURABILITY}

It is of interest to note the presence of tyloses (or sometimes of gums) in the large vessels of those hardwoods which are particularly valued for their durability. Many factors, such as the chemical composition of the wood, its rate of growth, and hardness, are, of course, important in determining durability, but the effect of tyloses should not be disregarded. Moreover the vigorous growth of parenchyma, which in some cases manifests itself by causing tylose formation and in others by producing tannins, essential oils, etc., appears to be a fundamental characteristic of naturally durable woods. White oak, in which tyloses are abundant, is, for example, more durable than red oak, in which they are almost wholly absent. The tylose walls present an added obstruction to the advance of fungous hyphæ and tend to make the vessels impenetrable to air and water. They are especially effective in woods that have been dried.

Although sapwood contains tyloses, it is usually less durable than heartwood. The latter fact, however, holds true also for woods without tyloses and can probably be explained by the condition of such materials

\footnotetext{
1 The illustrations reproduced in PI. LVIII of all conditions of open and closed horizontal resin canals were taken from sapwood material.
} 
in the sapwood as starches, which undergo a transformation when the heartwood is formed.

The following tabulation of the "Relative durability of hardwoods," compiled from the results of experiments, indicate that tyloses are a factor in durability. The more durable species will be found, with a few exceptions, to contain many or very abundantly developed tyloses. (See Tables I and II.)

RELATIVE, DURABILITY OF HARDWOODS 1

Durable.

Black locust.

Catalpa.

Osage orange.

Mulberry.

Yellow poplar.

Red ash.

Cottonwood.

White elm.

Red gum.

Hard maple.

White ash.
Chestnut. Black walnut. Live oak. Sassafras.
White oak. Post oak. Black ash. Honey locust.
Cherry.

Persimmon. Slippery elm. Bur oak.

Fairly durable.

Red oak.

| Scarlet oak.

Butternut.

Not durable.

The results of tests on 30,160 fence posts ${ }^{2}$ indicated the following untreated hardwoods, in order of their durability, as the most suitable: Osage orange, locust, mulberry, catalpa, certain oak (species not given), and black walnut. The length of life in service varied from io to 50 years.

Some observations ${ }^{3}$ on the life of untreated hardwood railroad ties further confirm the relation between tyloses and durability. It must be borne in mind, however, that for this type of service hardness has been considered in judging durability. The list of woods, together with their life in years under traffic, is as follows:

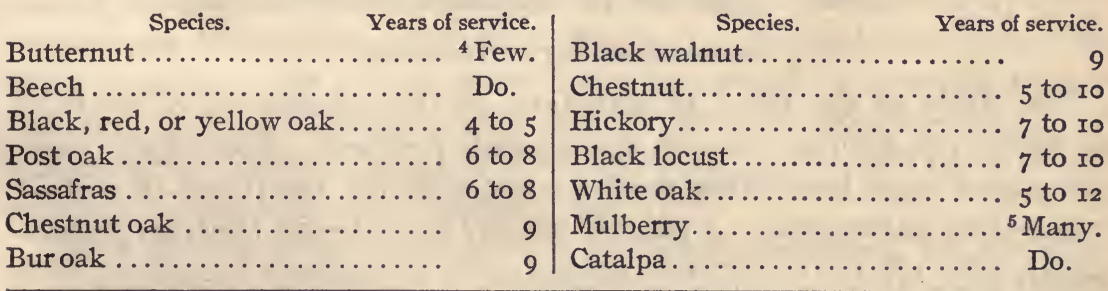

\footnotetext{
1 This list is offered to show the comparative durability of some American timbers. It is not presumed to obtain for all conditions.

2 Crumley, J. J. The relative durability of post timbers. Ohio Agr. Expt. Sta. Bul. 219, p. 605-640, I0 pl. I910.

8 Tratman, E. E. R. Report on the use of metal railroad ties and on preservative processes and metal tie-plates for wooden ties. U. S. Dept. Agr., Div. For. Bul. 9, p. $216 . \quad$ x894.

4 Life not given.

${ }^{5}$ Little used.
} 
A few exceptions are noticeable. Chestnut oak, for example, has very few tyloses, but is hard and strong. Butternut has many tyloses, but it is also much softer than the oaks. Hickory has many tyloses and is here considered as durable a wood as black walnut. This is contrary to observations of its durability by other investigators. The kind of beech used is not specified, but if it was "white-heart" beech tyloses were not present. The "red-heart" beech, which contains tyloses, is often reported as a very durable wood.

The following recent estimates are based on experience and actual inspection by the Forest-Products Laboratory of woods in service (Table IV):

TABLE IV.-Life of untreated wood placed subject to decay.

\begin{tabular}{|c|c|c|c|}
\hline Untreated material. & Years. & Untreated material. & Years. \\
\hline $\begin{array}{c}\text { Tyloses abundant or many; well } \\
\text { developed. }\end{array}$ & & $\begin{array}{l}\text { Tyloses lacking or scattered; few } \\
\text { or weakly developed-Contd. }\end{array}$ & \\
\hline Lumber: & & Lumber-Continued. & \\
\hline Chestnut.... & 12 & Maple........... & \\
\hline White oa & 8 & Birch... & \\
\hline Posts: & & Poplar......... & \\
\hline Locust & 25 & Cottonwood........... & \\
\hline orange........ & 40 & Tupelo................. & \\
\hline Mulb & 20 & od.................. & \\
\hline Catal & $\mathrm{I}_{4}$ & zeart beech..... & \\
\hline Ches & Io & Red gum............. & \\
\hline White oak. & 8 & Sycamore...... & \\
\hline Ties: & & Posts: & \\
\hline Black lo & 20 & Red oak........ & \\
\hline White oak.............. & 8 & Ash $\ldots \ldots \ldots \ldots \ldots \ldots \ldots$ & \\
\hline Chestnut................. & 7 & Aspen...$\ldots \ldots \ldots \ldots \ldots \ldots$ & \\
\hline Tyloses lacking or scattered; few & & Ties: & \\
\hline or weakly developed. & & $\begin{array}{l}\text { White-heart beech } \ldots \ldots \ldots \\
\text { Birch.................... }\end{array}$ & \\
\hline Lumber: & & Maple..... & \\
\hline Elm. . & 7 & Red oak $\ldots \ldots \ldots \ldots \ldots \ldots$ & \\
\hline Ash.. & 5 & Gum................... & \\
\hline
\end{tabular}

\section{TYLOSES A FACTOR IN CREOSOTE PENETRATION}

\section{EXPERIMENTS WITH HARDWOODS}

The study of the effect of structure on the penetration of artificial preservatives, such as creosote, is a separate problem. Preliminary work has shown some interesting results concerning the treatment of certain tylose-filled hardwoods. A piece of air-dry black locust (Robinia pseudacacia), 9 by $I \frac{1}{2}$ by I inch, was subjected to a thorough treatment with creosote in a treating cylinder. The piece contained sapwood and heartwood, the vessels of both of which were filled with tyloses. The stick when split open after treatment showed no penetration except a faint discoloration in the outer one-fourth inch of sap, which apparently did not extend to the tyloses filling the vessels, but was located only in a few scattered groups of fibers. The failure of the wood to absorb creosote 
was not entirely due to the presence of tyloses, but the fact that the creosote did not penetrate the tylose-filled vessels is significant.

In a piece of desert willow (Chilopsis linearis), 4 by $\mathrm{I} 1 / 2$ by 2 inches, treated with carbolineum, no penetration was visible in the heartwood except about one thirty-second of an inch near the surface. In the sapwood, however, where, as shown in Table I, the large vessels of the two outer growth rings are without tyloses, the dark discoloration of the preservative was clearly visible following the lines of these open vessels.

Sapwood in general absorbs creosote much more easily than heartwood. The supposed absence of tyloses in this region of the tree has previously been regarded as one reason for this fact. As soon, therefore, as it was satisfactorily determined that tyloses were unmistakably present in the sapwood, special experiments were undertaken to discover what effect they had on the absorption of the creosote. A piece of white oak was given a commercial treatment at the same time and under the same conditions as the black locust. The sapwood absorbed the oil fully, but the penetration stopped abruptly at the line of color demarkation between the sapwood and heartwood. (P1. LIX, fig. 2, B.) To the eye the heartwood, except for a surface coating, was absolutely untreated. The vessels in both the sapwood and heartwood of this piece were filled with strongly developed tyloses. Microscopic examination showed that the tyloses in the vessels of the treated sapwood were entirely uncolored and exactly like those in the vessels of the heart which was untreated throughout. The tyloses had then effectually kept the creosote out of the vessels, although there had been a full treatment of the wood fibers of the sapwood. This shows that a considerable quantity of the preservative was absorbed in spite of the fact that the presence of tyloses kept the creosote out of the vessels. Hence, tyloses of themselves need not be regarded as preventing the possibility of treating this species, at least in the sapwood.

A piece of oven-dried hickory, $2 \frac{1}{2}$ by $21 / 2$ by 14 inches, made up of both heartwood and sapwood, was treated at the same time and under the same conditions as the oak and locust, and showed a thoroughly good penetration throughout. (P1. LIX, fig. 2, C.) Nevertheless, when the wood was split, the tyloses, which were abundantly developed in the vessels of both the sapwood and heartwood, were white and unstained by the creosote, showing a marked contrast to the dark-brown fibers of the surrounding treated wood.

(P1. LII, fig. I.)

The preliminary observations just described concerning the penetration of creosote were based on results of treatments made on single specimens of the species studied and were regarded rather as valuable indications than as conclusive evidence. To check them with other results, the treatments with creosote were repeated on other specimens of the woods previously used and more specimens of another species containing many tyloses. First, a piece of hickory taken from miscellaneous material was given a high-pressure treatment with creosote. 
A good absorption was obtained in both the sapwood and heartwood. Nevertheless, the tyloses, which were everywhere well developed and undamaged in the large vessels of both regions, remained colorless and untreated. In addition, two other blocks of hickory from material collected with special care were also given pressure treatments in the cylinder. These specimens were from pignut hickory, Hicoria glabra, and mockernut hickory, Hicoria alba. Both specimens contained sapwood and heartwood, with tyloses strongly developed in the large vessels. Again, the wood was thoroughly treated with creosote in both the sapwood and the heartwood, and once more the tyloses could be observed on a split surface to be quite uncolored and visible even to the naked eye through their marked contrast with the blackish brown of the treated wood. (P1. LII, fig. I.)

Thus, results from four specimens of hickory from different sources clearly showed that in spite of the presence of tyloses a high absorption of creosote may be obtained in the wood substance outside of the vessels and the tyloses filling them.

The other species used in these experiments was the so-called red-heart beech, a form of Fagus atropunicea. This had white tylose-free sapwood, but a reddish heartwood with many tyloses. It was treated in the cylinder at the same time as some of the hickories. The sapwood was thoroughly penetrated, but the heartwood remained untreated except for a surface coating and a very slight infiltration near the ends.

Lastly, a second piece of white oak was treated, as a check on the piece treated previously. After the creosote treatment, which was given at the same time as that of the hickories and beech, the sapwood was found to be penetrated, and, as before, the heartwood was unpenetrated. Careful examination showed, however, that the discoloration of the creosote extended down the large vessels of the sapwood and into the tyloses which they contained. This apparent contradiction of previous observations was explained when the material was examined under the microscope. The tyloses were found to be full of fungous mycelium and riddled with holes produced by the hyphæ in passing through the tylose walls. Under these circumstances, even when abundant tyloses are present, it is clear that some penetration may be secured in the vessels.

The marked difference to be observed in the penetrance of creosote in treatments of red oak and white oak is, however, chiefly the result of the presence or absence of tyloses. The unobstructed vessels of red oak give such open channels and offer so much additional surface for absorption through their walls that the penetrability of the other elements lying between the vessels is of relatively little importance. In white oak, on the other hand, it is only the elements of structure other than the large vessels that are available for penetration. The type of penetrance obtained in red oak is shown in Plate $\operatorname{LIX}$, figure $2, A$. The dark streaks mark the course of the creosote, which passed almost entirely 
through the open vessels. The practical effect of this is evident in the results obtained in penetrance treatments. It is possible to force creosote for long distances through red oak just as it would be possible to force it through similar distances in small open pipe lines. In comparison with this, the distance the oil will pass through white oak is very short, since it has to penetrate through many cell walls, and the resistance of the material must be overcome by high pressures.

Thus, although tyloses have a distinct effect, they are not the only factor in the penetrance of wood. The characteristics of the other elements in the annual ring must be considered. However, in the cases examined, wherever the large vessels contained abundantly developed tyloses or filling cells, the vessels and the tyloses, but not necessarily the rest of the woody tissues, were impenetrable to creosote.

\section{OBSERVATIONS ON CONIFERS}

The presence of resin canals and their condition-that is, whether they are open or partly or entirely closed by cells - considered in conjunction with the general permeability of the tracheids, is a factor of practical significance in the selection of wood for creosoting. (Pls. LVI and LVII.) The number of the resin canals is very small in comparison with the number of tracheids. However, if the canals are unobstructed, penetrance is easily obtained for considerable distances through their cavities. In a wood whose tracheids are penetrated with difficulty, the creosote does not spread to any great extent from the canals into the tracheids, even when the former are full. Nevertheless, the presence of creosote or other toxic liquid in the resin-canal regions, which are among the first affected by fungous infection, is of considerable assistance in prolonging the life of the wood. Many of the resin canals, especially the vertical canals in both the sapwood and the heartwood of the pines, are not completely closed (P1. LVII, fig. I, and P1. LVIII, figs. I and 4) and can for this reason be penetrated. The effect of the presence or absence of tylose-like cells in the resin canals, while a minor factor, is significant in connection with the treatment of poles, ties, and paving blocks.

\section{EFFECT OF TYLOSES ON THE WATER-LOGGING OF WOOD}

In order to test the effect of tyloses on the water-logging of wood, some roughly comparable air-dry blocks of several species were placed in a tank of water and the length of time required to water-log each block sufficiently to sink it was noted. The blocks were grouped with reference to their specific gravity (dry) ${ }^{1}$ and their actual weight. The woods in which tyloses were few or wholly lacking invariably sank before those containing abundant tyloses. Chestnut oak sank before white oak and bur oak, persimmon before osage orange, flowering dogwood before hickory, yellow poplar and aspen before catalpa, and blue beech and honey locust

\footnotetext{
1Sargent, C. S. Report on the Forests of North America ... 6ra p., maps. Washington, 8884. (U. S. [roth Census Reports, v. 9].)
} 
before black locust. The dogwood and persimmon sank in about i 8 hours, while the catalpa floated for 20 days, and one piece of black locust with a large percentage of heartwood remained floating for 46 days.

\section{SUMMARY}

The 143 specimens of hardwoods examined included 45 genera (94 species), of which 24 contained tyloses. The 60 specimens of conifers examined included 13 genera ( 45 species), of which I contained tyloses. Of the 139 species examined, 56 , belonging to 25 genera, contaired tyloses.

Tyloses were found in the sapwood of all species in which they occurred in the heartwood.

Well-developed tyloses were found in the outermost rings near the bark of 30 species of hardwoods.

True tyloses occur in the wood tracheids of certain pines, principally of the white-pine group.

Epithelial cells sometimes effect a partial or even complete tyloselike closing of the resin canals in Pinus, Larix, Picea, and Pseudotsuga.

A considerable proportion of the vertical canals, even in the heartwood of the pines, are fully or partly open.

Tyloses act like a natural filler in the hardwoods.

The woods in which tyloses are abundant as a rule are durable.

Tyloses, because they are very impermeable to air, water, and creosote, reduce the penetrance of the woods in which they are strongly developed. The presence of tyloses in the vessels of a hardwood, however, does not prevent the penetrance of creosote into the other wood elements.

BARLEY, I. W.

\section{LITERATURE CITED}

I9I3. Preservative treatment of wood. In Forestry Quart., v. II, no. I, p. $5^{-20}, 2 \mathrm{pl}$.

BARY, ANTON DE.

1884. Comparative Anatomy of the Vegetative Organs of the Phanerogams and Ferns. Translated by F. O. Bower and D. H. Scott ... p. I70. Oxford.

BOEHM, JOSEF.

1867. Ueber Function und Genesis der Zellen in den Gefassen des Holzes. In Sitzungsber. K. Akad. Wiss. [Vienna], Math. Naturw. Cl., Abt. 2, Bd. 55, p. $85 \mathrm{I}-866,2 \mathrm{pl}$.

1877. Ueber den aufsteigenden Saftstrom und den Abschluss lebender Zellen gegen äussere Einwirkungen. In Bot. Ztg., Jahrg. 35, No. 7, p. I12-II3.

1879. Ueber die Function der vegetabilischen Gefässe. In Bot. Ztg., Jahrg.

Chryslek, M. A. 37 . No. 15, p. 225-239; No. 16, p. $241-25^{8}$.

1908. Tyloses in tracheids of conifers. In New Phytol., v. 7, no. 8, p. I98-204, p1. 5 .

HABERLANDT, G. F. J.

1884. Physiologische Pflanzenanatomie. p. 217. Leipzig.

1887. Ueber die Beziehungen zwischen Function und Lage des Zellkernes bei den Pflanzen. p. 7x-74. Jena. 
HANAUSEK, T. F.

1907. Microscopy of Technical Products. Translated by A. L. Winton and Kate G. Barber. p. 200. New York.

KÜSTER, ERNST.

I903. Pathologische Pflanzenanatomie. $3^{12}$ p., illus. Jena.

MAYR, HEINRICH.

I883. Über die Vertheilung des Harzes in unseren wichtigsten Nadelholzbäumen. In Flora, Jahrg. 66 (n. R. Jahrg. 4I), No. I4, p. 223.

1884. Enstehung und Vertheilung der Secretions-Organe der Fichte und Lärche. In Bot. Centbl., Bd. 20, No. 8, p. 246-253; No. 9, p. 278283; No. 10, p. 308-310, pl. I-3.

1893. Das Harz der deutschen Nadelwaldbäume. In Ztschr. Forst u. Jagdw., Bd. 25 , p. 313-324, 389-417, 565-593, 654-670, pl. x-2. Reprinted as

MOLISCH, HANS. Das Harz des Nadelhölzer ... 1894 .

I888. Zur Kenntniss der Thyllen, nebst Beobachtungen über Wundheilung in der Pflanze. In Sitzungsber. K. Akad. Wiss. [Vienna], Math. Naturw. Cl., Abt. I, Bd. 97, Heft 6, p. 264-298, 2 pl.

Penhaliow, D. P.

I907. Manual of the North American Gymnosperms ... 374 p., illus. Boston.

PraAal, EDmund.

I888. Vergleichende Untersuchungen über Schutz- und Kern-Holz der Laubbäume. In Jahrb. Wiss. Bot., Bd. r9, p. I-8r, pl. I.

RAATZ, WILHELM.

I892. Ueber Thyllenbildungen in den Tracheïden der Coniferenhölzer. In Ber. Deut. Bot. Gesell., Bd. ro, p. 183-r92.

REESS, MAX

I868. Lur Kritik der Böhm'schen Ansicht über die Entwickelungsgeschichte und Function der Thyllen. In Bot. Ztg., Jahrg. 26, No. I, p. I-II, pl. I.

I896. Lehrbuch der Botanik. p. 88. Stuttgart.

RUsSOW, EDMUND.

I872. Vergleichende Untersuchungen ... der Leitbündel-Kryptogamen, mit Berücksichtigung der Histologie der Phanerogamen ... 207 p., II pl. St. Pétersbourg. (Mém. Acad. Imp. Sci. St.-Pétersb., s. 7, t. I9, no. I.) r883. Zur Kenntniss des Holzes, insonderheit des Coniferenholzes. In Bot. Centbl., Bd. I3, No. 4, p. I34-I44; No. 5, p. 166-173, pl. I-5.

Sachs, Jurius.

I887. Lectures on the Physiology of Plants. Translated by H. M. Ward. p. $5^{81}$. Oxford.

STRASBURGER, FDUARD.

I89r. Ueber den Bau und die Verrichtungen der Leitungsbahnen in den Pflanzen.

p. I9I. Jena. (His Histologische Beiträge, Heft 3.)

r902. Das botanische Practicum ... Aufl. 4, p. 249. Jena.

- Schenck, Heinrich, Noli, Fritz, and Karsten, George.

1908. Text-Book of Botany. ed. 3, rev. with German ed. 8, 746 p., illus. London.

Thomson, R. B.

I9r3. On the comparative anatomy and affinities of the Araucarineae. In Phil.

WINCKLER, HANS.

Trans. Roy. Soc. London, s. B, v. 204, p. I-50, pl. I-7.

I905. Ueber einen neuen Thyllentypus nebst Bemerkungen über die Ursachen der Thyllenbildung. In Ann. Jard. Bot. Buitenzirg, v. 20 (s. 2, v. 5), pt. $x$, p. I9-37. 


\section{PLATE LII}

Fig. I. - Split radial face of a creosoted hickory block, showing tyloses $(T)$ in a large vessel. Magnified 12 diameters. Tyloses uncolored; remaining wood substance black with creosote.

Fig. 2.-Tangential section of Aesculus octandra, yellow buckeye $\times 680$, showing two tyloses $(T)$ which have grown out of one medullary-ray parenchyma cell $(M R)$. Shows open connection between the tyloses and parenchyma cell.

Fig. 3.-Cross section of valley oak, a white oak, showing young tyloses $(T)$ next the bark $(B)$ in vessels $(V)$. 

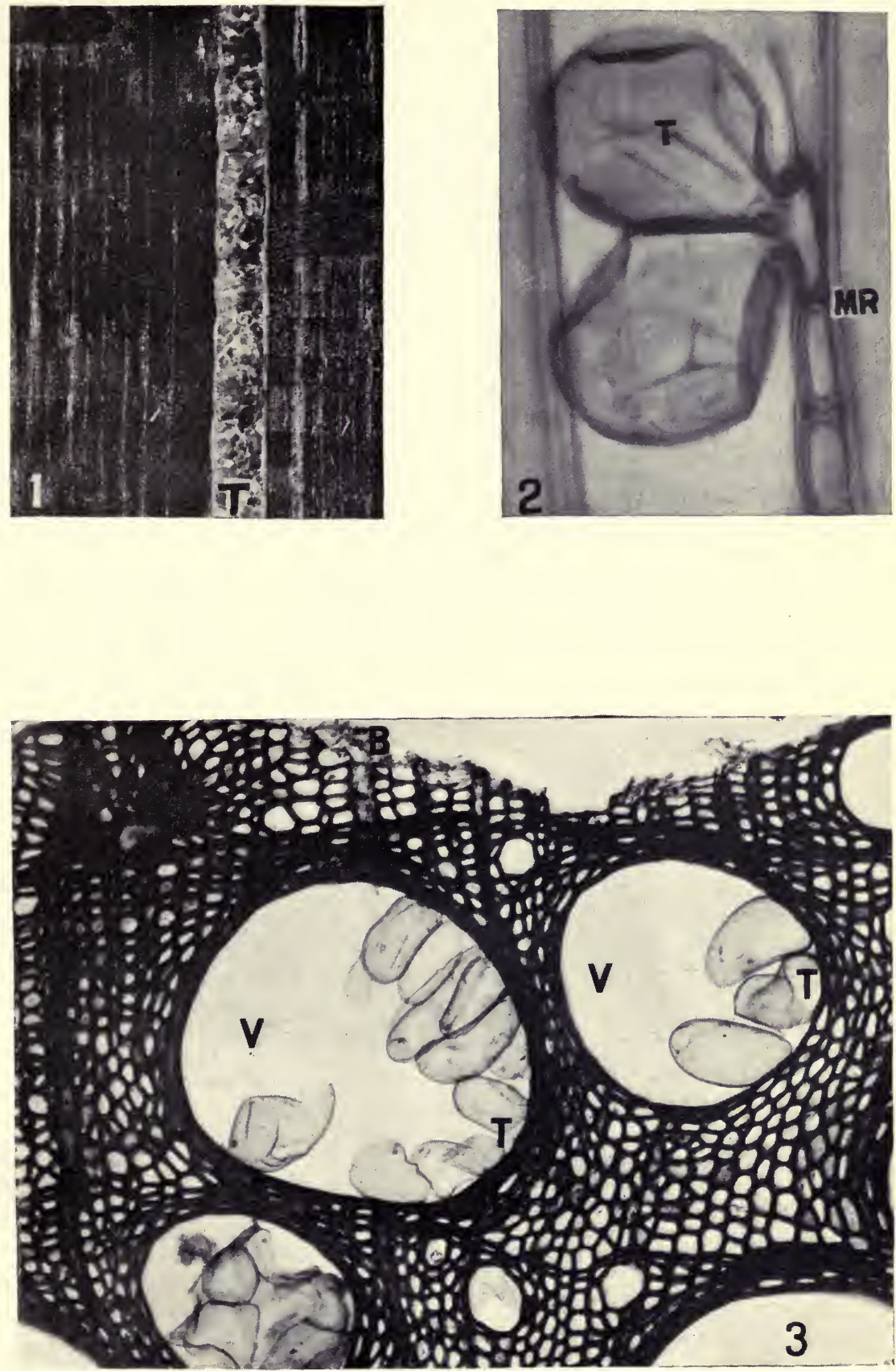

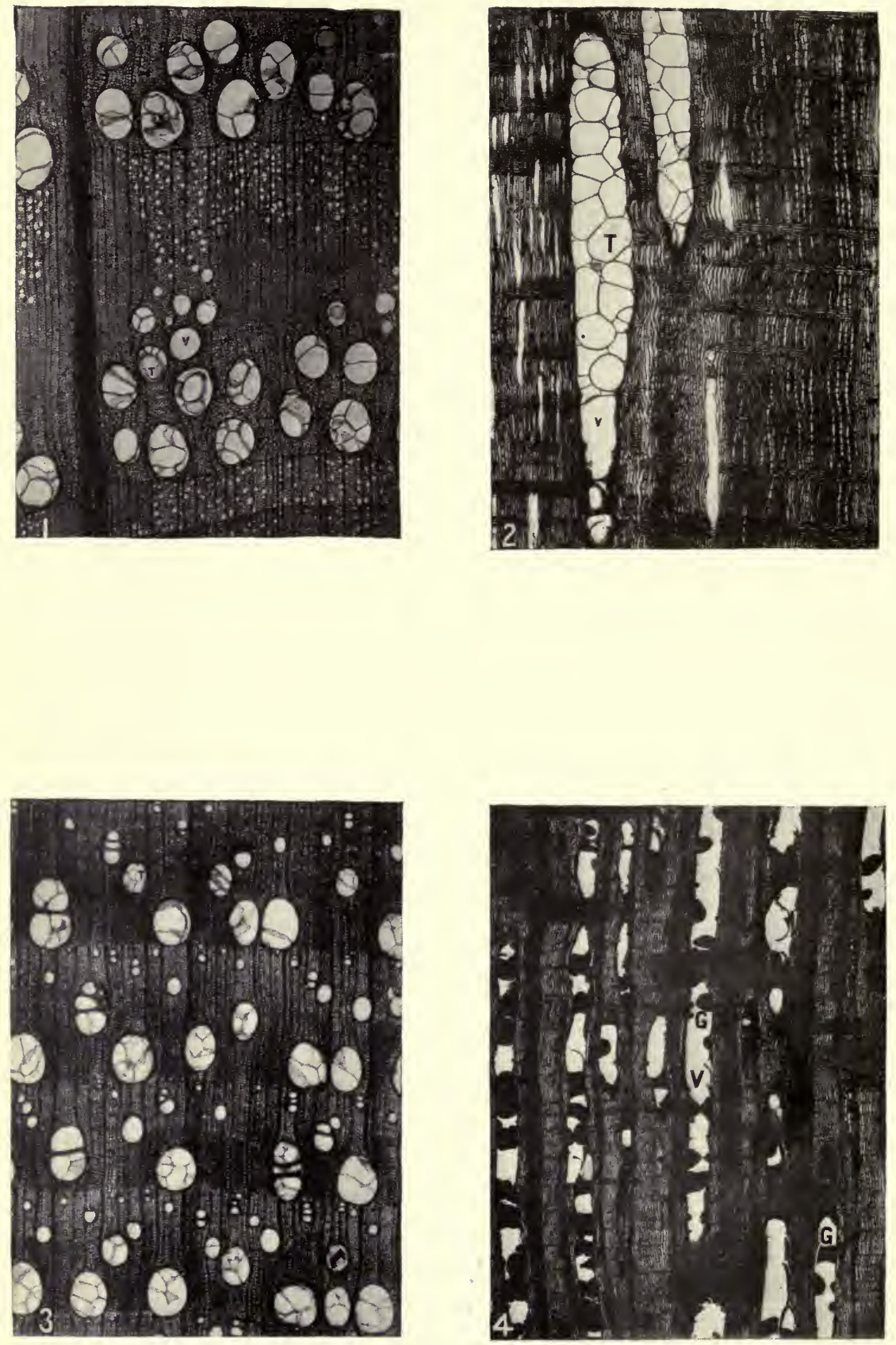


\section{PLATE LIII}

Fig. 1.-Cross section of a white oak, showing fully developed tyloses $(T)$ in the large vessels $(V)$.

Fig. 2.-Radial-longitudinal view, quarter-sawed surface, of the white oak shown in figure $I$, showing complete closing of the vessel $(V)$, which makes this wood valuable in light cooperage, etc.

Fig. 3.-Cross section of sapwood of pignut hickory, showing fully developed tyloses $(T)$.

Fig. 4.- Radial view of mesquite, showing "gum" droplets $(G)$ and formations often stimulating tyloses. 


\section{PLATE LIV}

Cross section of cow oak, a white oak, showing normal and abnormal tyloses. From top to bottom are bark $(B)$ and three annual growth rings $\left(R_{1}, R_{2}, R_{3}\right)$.

Fig. 1.-Wound tyloses $(W T)$ induced by the felling of the tree and the sudden cessation of sap flow.

Fig. 2. - No tyloses $(V)$; empty vessels. Normal tyloses not yet developed.

Fig. 3.-Young (YT) and well-developed normal tyloses $(T)$. 


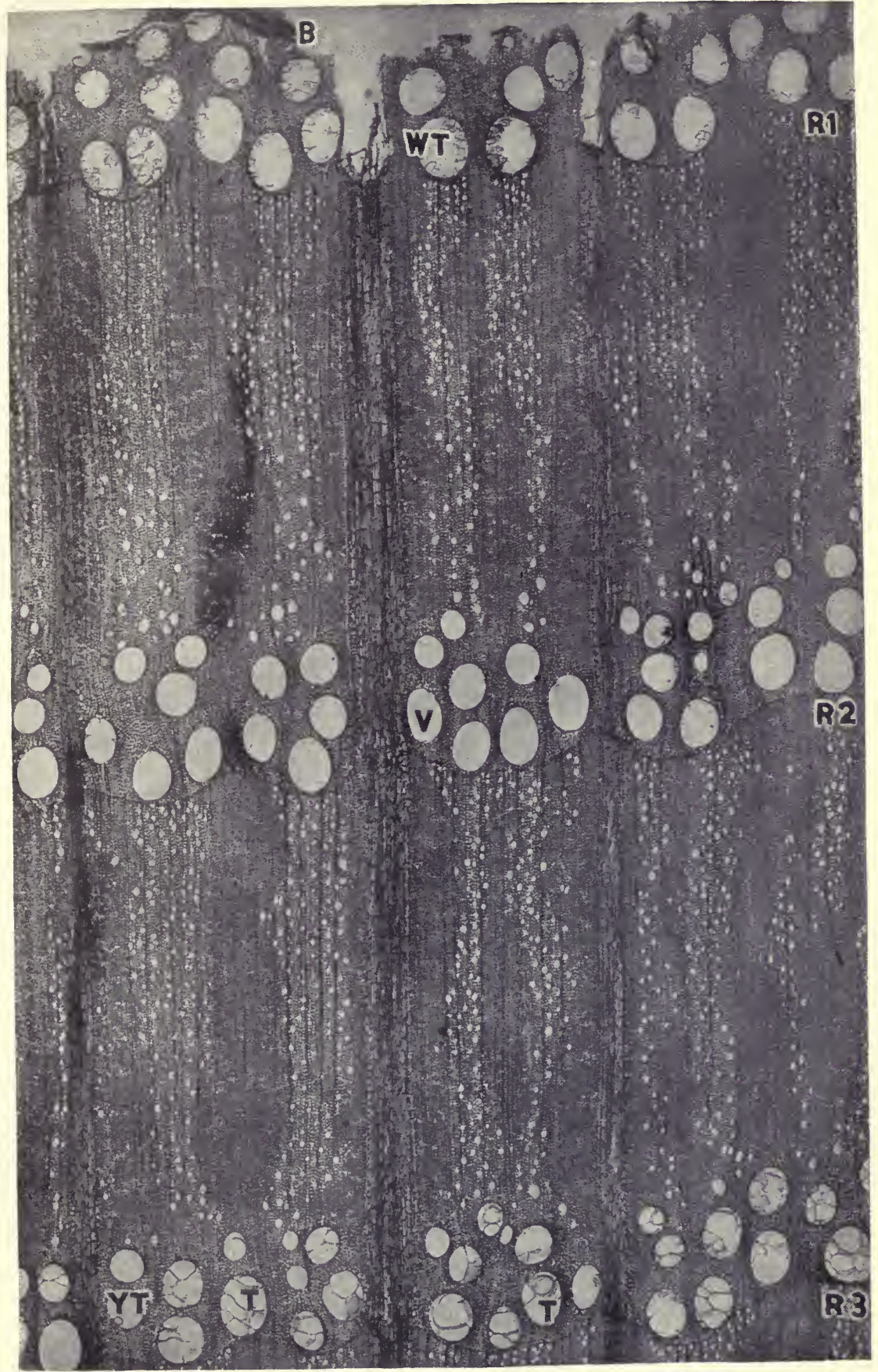



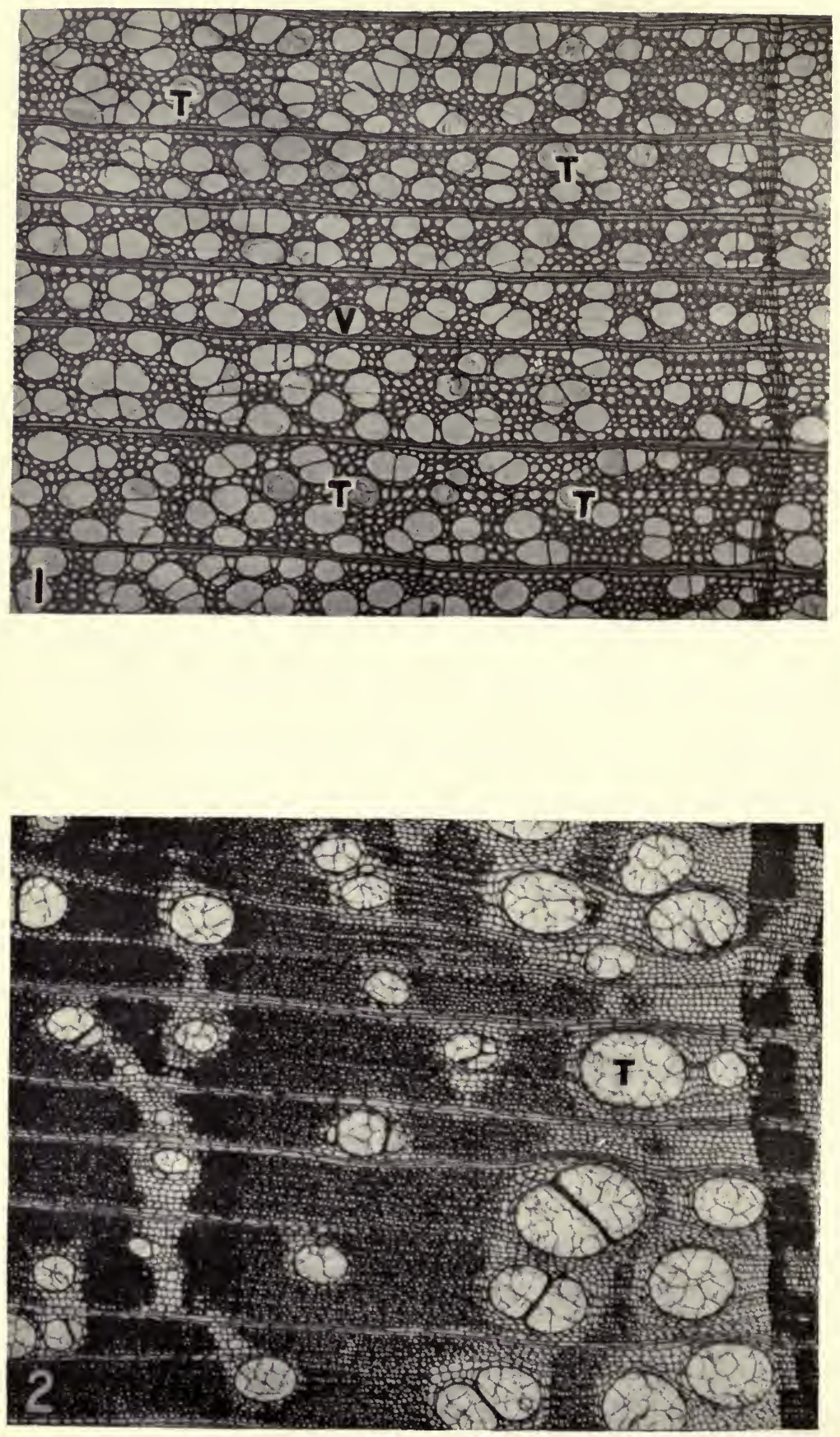

Journal of Agricultural Research

Vol. I, No 6 
PLATE LV

Fig. I.-Cross section of a diffuse porous wood, yellow poplar or tulip, showing scattered tyloses $\times$ 50. $T$, tylose-filled vessels; $V$, empty vessels.

Fig. 2.-Cross section of a ring porous wood, osage orange, with vasicentric parenchyma, showing abundantly developed tyloses $(T) \times 50$. 
Fig. I.-Cross section of western white pine, showing ray tyloses $(T)$, closed vertical resin canal $(V R C)$ in young sapwood, and nuclei $(N)$ visible in epithelial cells of canal which is beginning to split open at $S$.

Fig. 2. - Tangential section of Norway pine, showing ray tyloses $(T)$. 

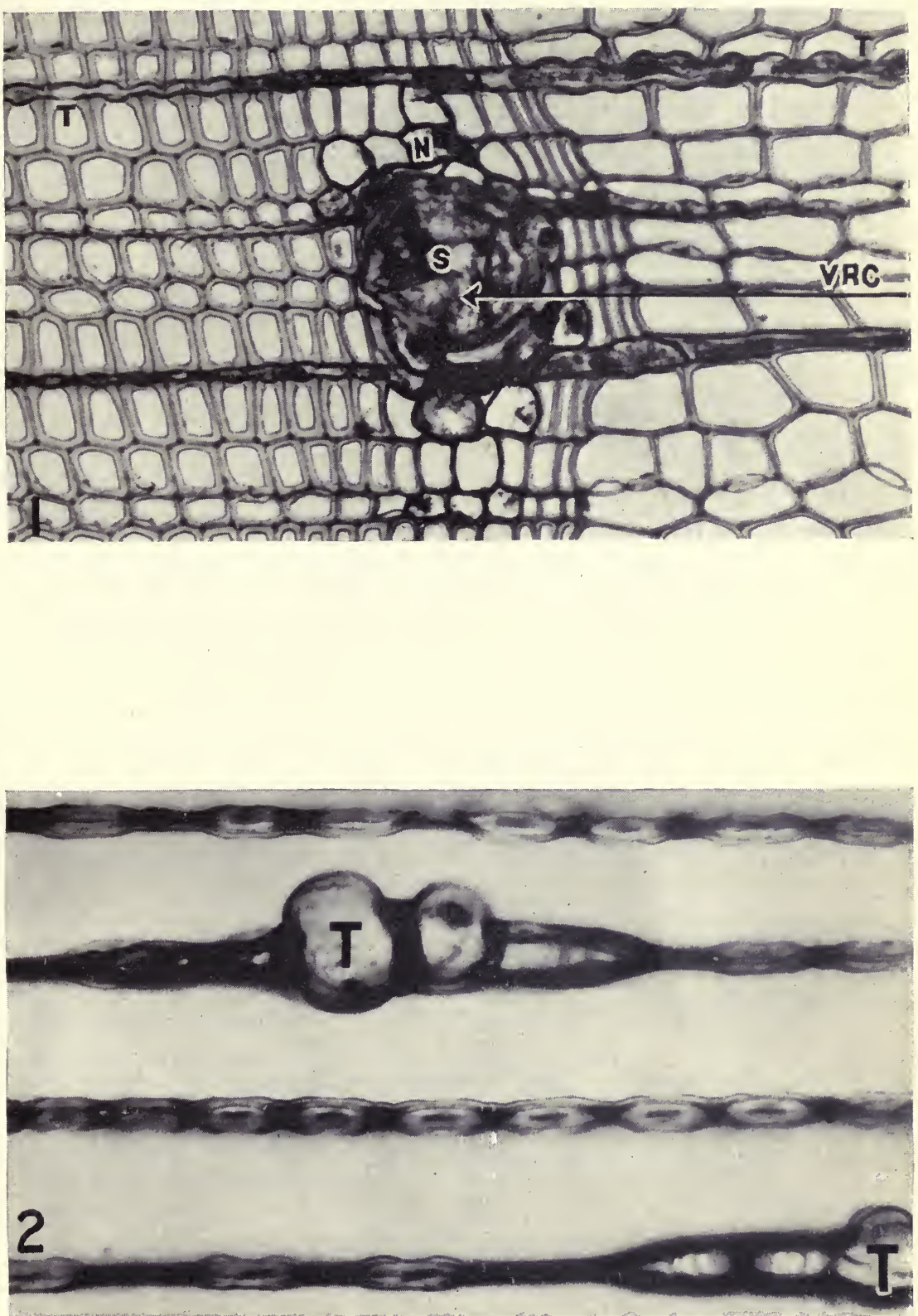

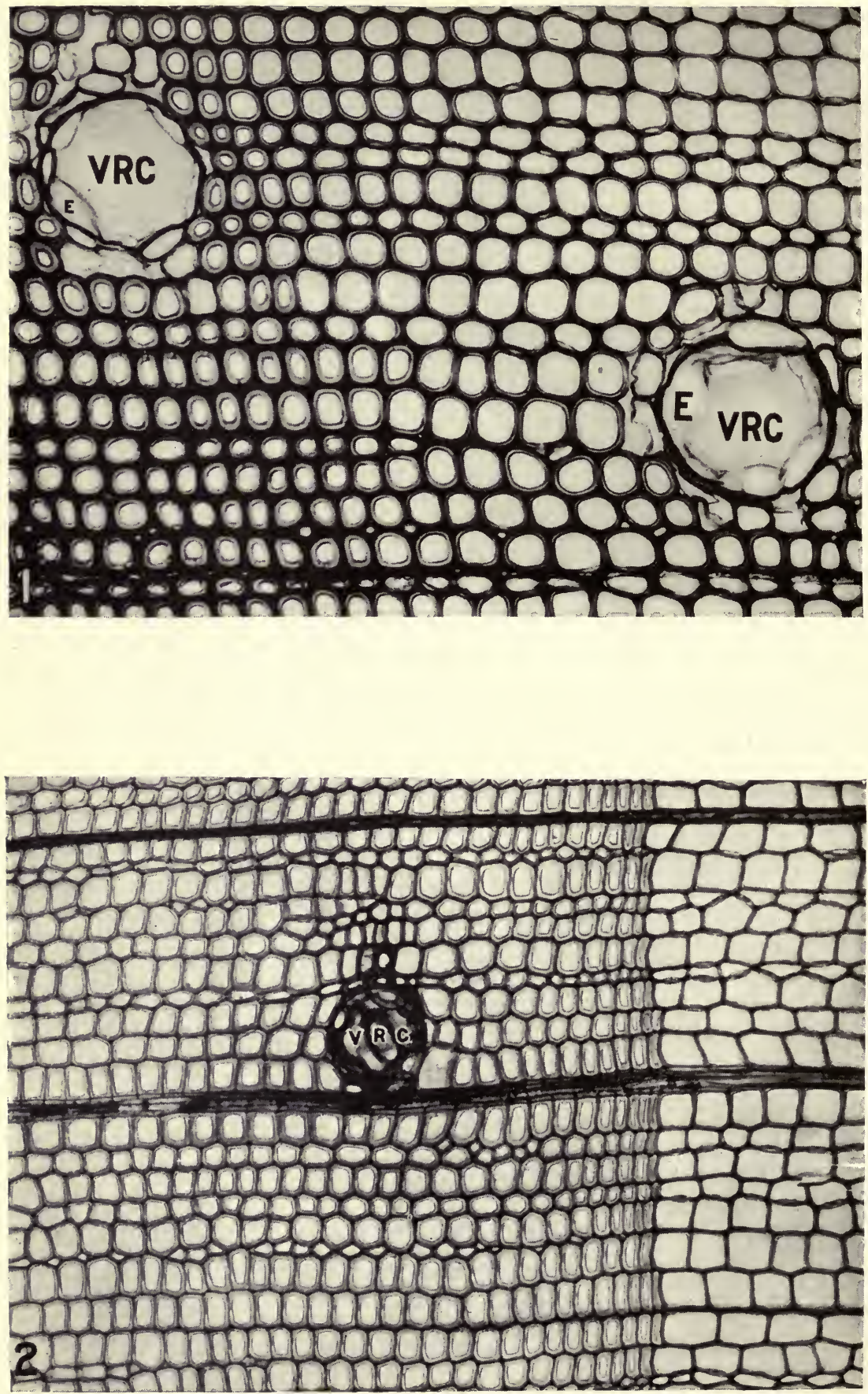


\section{PLATE LVII}

Fig. I.-Cross-section view of shortleaf pine, showing open and partly closed vertical resin canals $(V R C)$. These are typical of many canals in pine heartwood. Shows thin-walled epithelial cells $(E)$.

Fig. 2.-Heartwood of Sitka spruce, showing closed vertical canal (VRC). 


\section{PLATE LVIII}

Open and closed horizontal canals in sapwood.

Fig. 1.-Open canal in tamarack (TE) thick-walled epithelium.

Fig. 2.-Partly closed canal with distended epithelial cells $(D E)$ in Douglas fir.

Fig. 3.- Young canal which has never opened in western white pine. Cells with protoplasm and nuclei. Vertical canal $(V R C)$ in same condition on right; this is longitudinal view of same canal as is shown in cross section, Plate LVI, figure I.

Fig. 4.-Open canal in red spruce surrounded by thick-walled epithelium (TE).

Fig. 5.-Partly closed canal in red spruce. $T E$, thick-walled, and $D E$, thinwalled distended epithelial cells.

Fig. 6.-Closed canal in Engelmann spruce. From old sapwood. The epithelial cell has completely closed the canal and its wall has become thickened. 

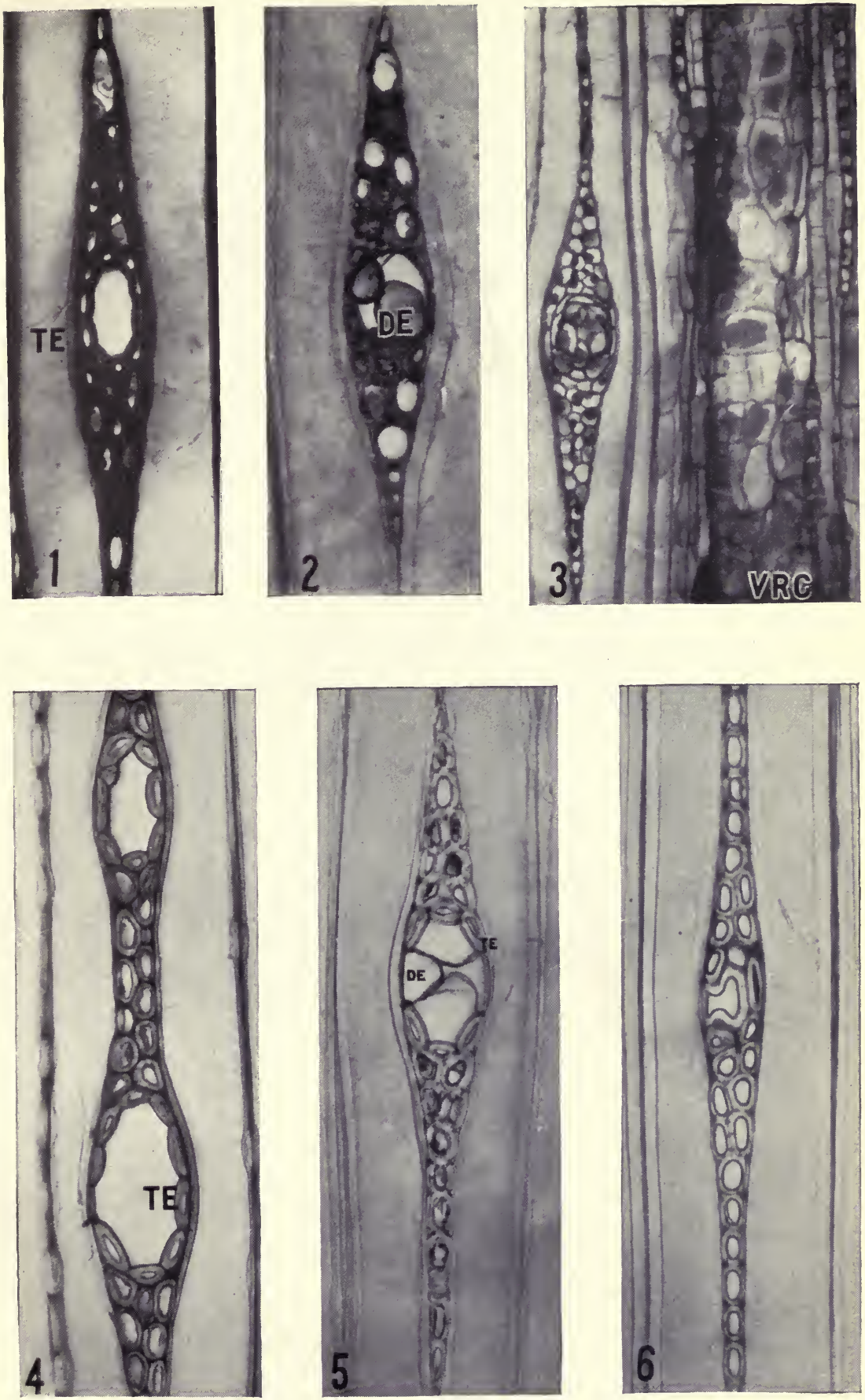

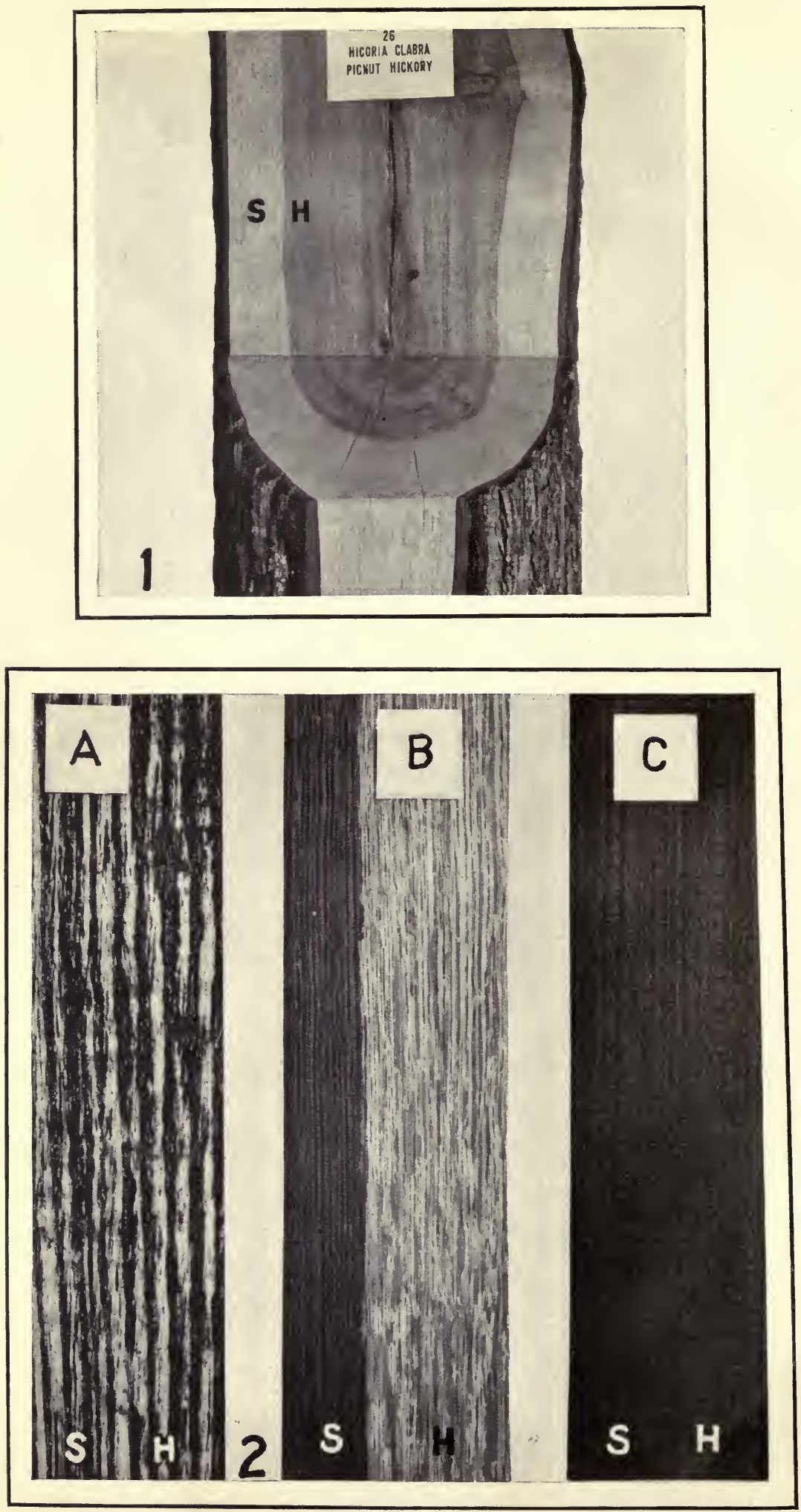


\section{PLATE LIX}

Fig. I.-Log from collection of woods in the Forest-Products Laboratory-a specimen of the material used in this study; $S$, sapwood; $H$, heartwood.

Fig. 2.-Specimens of woods showing creosote penetrance in sap and heartwood as affected by tyloses. The three specimens each contain both sapwood and heartwood. Specimen $A$.-Red oak. Has no tyloses; creosote passed chiefly down the large vessels; note black streaks. Wood substance between vessels little treated; note white streaks. Specimen B.-White oak. Has abundant tyloses in sap and heartwood. Creosote penetrated the sapwood only. Thorough absorption obtained in the sapwood substance between the impenetrable, tylose-filled vessels. Specimen C.-Pignut hickory. Has abundant tyloses in sap and heartiwood. Creosote penetrated both. Good absorption throughout in the wood substance between the tylose-filled vessels. Compare Plate LIII, figure I, an enlarged view of a portion of this block.

$$
28736^{\circ}-\mathrm{r} 4-3
$$



[Reprinted from Scirnoe, N.S., Vol. XXXV., No. 889, Pages 75-77, January 12, 1912]

\section{TIER-LIKE ARRANGEMENT OF THE ELEMENTS OF CERTAIN WOODS}

There are numerous woods which present on longitudinal section (particularly the tangential) fine, delicate cross lines or stripes sometimes called "ripple marks." The distance between these markings varies from 0.11 to $0.50 \mathrm{~mm}$., and is fairly constant for a species. On some woods (e. g., Alsculus octandra Marsh., Swietenia mahagoni Jacq., Bombax insigne Wall. and Pterospermum diversifolium Blume.) these lines are very clear and distinct to the unaided eye; on others (e. g., Tilia americana L., T. pubescens Ait., Pterocarpus indicus Willd. and P. dalbergioides Roxb.) they are near the limit of vision or again (e. g., Guaiacum sanctum L. and $G$. officinale $\mathrm{T}$.) thev are invisible without the lens. In most species showing these markings the feature is constant and of considerable importance for diagnostic purposes. though in a few species (e. g.. Swietenia mahagoni) the same piece of wood may show the markings in one place and not in another.

This cross-striping of a wond is due (1) to the arrangement of the ravs in horizontal series. or (2) to the tier-like ranking of the wood fibers, vessel segments or other elements. or (3) to a combination of (1) and (2). The lines resulting from the horizontal seriation of the rays is usually more conspicnous and of more common occurrence than those in (2). In the combination of the two forms, which is very common, the junction of the vessel segments or of the fibers is usually between the rays.

This peculiar arrangement of wood elements is also evidenced on transverse section.
Where the rays are in perfect horizontal seriation a section between two tiers shows an entire absence of rays. In most instances, however, it results in gaps of irregular width depending upon the regularity of the stories. Where the rays are much wider near the middle than at the margin their apparent width when viewed transversely will show con. siderable variation, according to the relative location of the plane of section. Where the fibers are arranged in tiers their apparent size is affected in a similar manner. According to von $\mathrm{Höhnel}^{1}$ the fibers in Bocoa provacensis Aubl., and a few other tropical woods with cross-striping are also radially disposed, and when the plane of cutting passes near the junction of two tiers the section shows large and small cells in alternate radial rows. The small cells are sections of the tips of the fibers forced by growth between their upper and lower neighbors. It is von Höhnel's theory that their appearance in alternate radial rows instead of alternately in the same row is the result of the pressure of the bark upon the cambium while the fibers were being formed.

Tier-like arrangement is most common in tropical woods and has been found fairly characteristic of the families Cæsalpiniaceæ

${ }^{1}$ Von Höhnel, Franz Ritter, "Ueber stockwerkartig aufgebaute Holzkörper,' Sitzungsberichte der Mathematische-Naturwissenschaftlichen Classe der kaiserlichen Akademie der Wissenschaften, Vol. 89, Part 1, Wien, 1884, pp. 30-47. Von Höhnel, Franz Ritter, "Ueber den etagenformigen Aufbau einiger Holzkörper,", Berichte der Deutschen Botanischen Gesellschaft, Vol. II., Berlin, 1884, pp. 2-5. 
and Zygophyllaceæ. Various writers ${ }^{2}$ have called attention to this feature which is especially striking on red sanders (Pterocarpus santalinus L. f.), narra ( $P$. indicus Willd.), and Jamaica quassia (Picrasma excelsa Planch.). Von Höhnel (loc. cit.) observed it in about 80 different woods, all tropical or sub-tropical but one (Diospyros virginiana L.), and most of them unidentified. His list of the identified woods includes 35 genera of 12 families, viz., Cæsalpiniaceæ, Papilionaceæ, Mimosaceæ, Zygophyllaceæ, Büttnereaceæ, Malvaceæ, Cedrelaceæ, Bignoniaceæ, Simarubaceæ, Ebenaceæ, Rosaceæ and Sapindaceæ.

Included in v. Höhnel's list are two species which occur in the United States, viz., Swietenia mahagoni and Diospyros virginiana. In addition to these two the present writer has observed tier-like arrangement in the woods of Esculus octandra, Tilia americana, T. pubescens, T. heterophylla Vent. and Guaiacum sanctum.

\section{ASCULUS (BUCKEYE)}

In the wood of Assculus octandra the rays are fine, uniseriate, uniform, inconspicuous, mostly 10-12 cells high, measuring about 0.25 $\mathrm{mm}$. The average distance between the rays is, vertically, $0.15 \mathrm{~m}$; laterally, $0.06 \mathrm{~mm}$. Their arrangement is in horizontal series, very regular on the radial section but forming somewhat wavy lines on the tangential, though always plainly visible to the unaided eye. The ressel segments are from 0.35 to $0.40 \mathrm{~mm}$. long and are in series, the horizontal planes of their perforations alternating with the rays. The fibers appear not to be in storied arrangement.

The cross-markings on tangential surface are characteristic of $A$. octandra and were not observed in A. glabra Willd., A. cali-

${ }^{2}$ Flückinger, J. A., "Pharmacognosie der Pflanzen," 2d ed., pp. 463, 466. Wigand, A., "Anatomische Atlas zur pharmaceutischem Werkende," 1865, tables 26, 27. Whitford, H. N., "The Forests of the Philippines," Bul. 10, Bureau of Forestry, Manila, P. I., 1911, Vol. II., p. 36. fornica Nutt. or A. hippocastanum L., though all three show indistinctly on radial surface a tier-like arrangement of the wood elements. This feature is thus important in separating the wood of $A$. octandra from others of the genus.

\section{TILIA (BASSWOOD)}

Tier-like arrangement of the wood elements is characteristic of the woods of Tilia americana, T. pubescens and T. heterophylla. The ending of the vessel segments, wood fibers and wood parenchyma fibers is quite uniform. The rays are widely variable in size and are irregularly spaced. The small rays are uniseriate and mostly 10-15 cells high; the largest are 3-5 cells wide and 50-100 cells high. The cells are small and much flattened laterally.

The cross-markings of Tilia are not conspicuous, but in proper light are usually readily visible to the unaided eye. The average height of the tiers is about $0.40 \mathrm{~mm}$.

\section{SWIETENIA (MAHOGANY)}

Tier-like arrangement is often characteristic of the true mahogany (Swietenia mahagoni). While it may be absent, it is quite often very conspicuous. When present the tiers vary in height from 0.35 to $0.50 \mathrm{~mm}$. The rays are deep crimson in color, fusiform, and quite irregular in size; 1-5, mostly 2 or 3, cells wide, and 4-20, mostly 10-15, cells high. When the rays are in storied arrangement they coincide with the ressel segments.

Swietenia senegalensis Deso. is said by von Höhnel (loc. cit.) to be without cross-striping.

\section{DIOSPYROS (PERSIMMON)}

In Diospyros virginiana the rays are very numerous, composed of large cells in 1-2 (rarely 3) rows, and from 2-14, usually 1012 , cells high. They are arranged in horizontal series which correspond with the vessel segments, wood fibers and wood-parenchyma fibers. The arrangement is often somewhat irregular and is never conspicuous, though clearly visible to the unaided eye. The height of the tiers is about $0.35 \mathrm{~mm}$. 
The horizontal seriation of the rays appears to have been first described by Molisch. ${ }^{3}$

Available specimens of the wood of $D$. texana Sch. do not exhibit the cross-markings.

\section{GUATACUM (LIGNUM-VITE)}

The wood of Guaiacum sanctum exhibits very fine and quite uniform cross-markings, visible with the aid of the lens. The rays are very fine, uniseriate, mostly 5-7 cells high, deeply colored, appearing under lens like fine

"Molisch, H., "Vergleichende Anatomie des Holzes der Ebenaceen und ihrer Verwandten," Sitzungsberichte der Mathematische-Naturwissenschaftlichen Classe der kaiserlichen Akademie der Wissenschaft, Vol. 80, Part I., Wien, 1879. hachures. The height of the tiers varies from 0.15 to $0.18 \mathrm{~mm}$. The scattered vessels are filled with a dark-colored resin which adds to their prominence. The vessel segments alternate with the rays.

Guaiacum officinale L. is similar to $G$. sanctum in the arrangement of the wood elements. The distance between markings is often as low as $0.11 \mathrm{~mm}$. The rays are about $0.05 \mathrm{~mm}$. apart laterally and $90 \mu$ vertically.

In addition to those mentioned above, the writer has observed many tropical woods (particularly African and Brazilian) with tier-like arrangement of their elements.

SAMUEL J. RECORD

YALE FOREST SCHOOL 


\section{$4+145$}
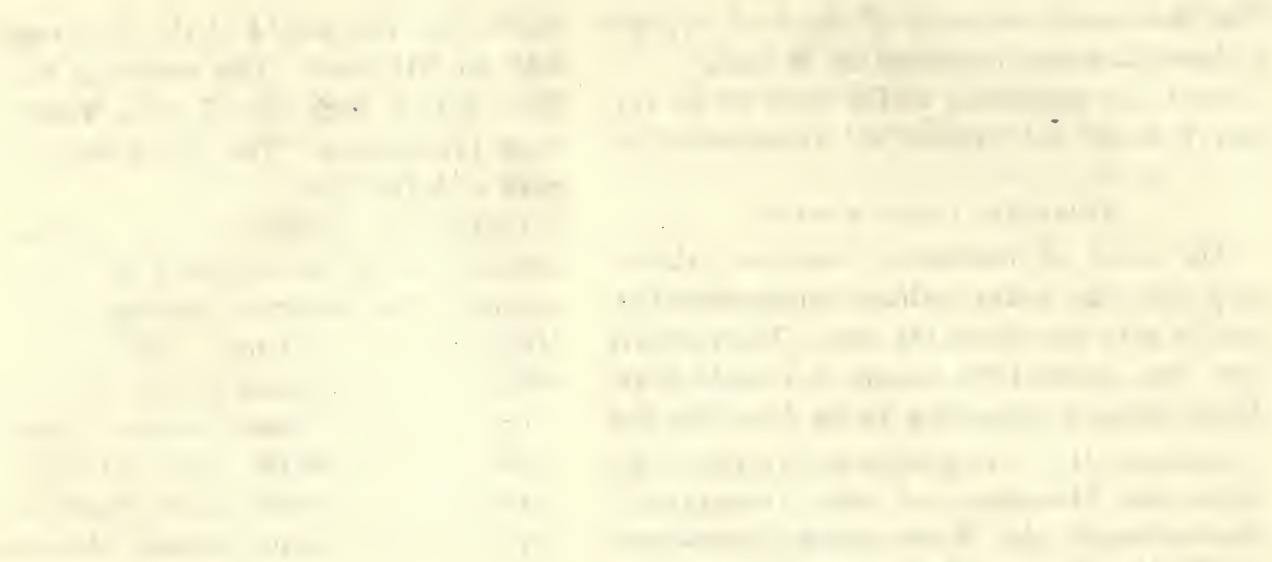

- 
[Reprinted from The Plant WORLD, Vol. II, No. 8, May, 1899].

\title{
Walter Mulford
}

\section{HISTORIC TREES OF NORTH AMERICA.}

\author{
By W. W. Rowlee. \\ I. - THE WASHINGTON ELM.
}

$\mathrm{B}$

EYOND doubt the most famous tree in America is the Washington Elm. It stands at the corner of Garden and Mason streets nearly opposite the middle of the west side of the Common in Old Cambridge. New Englanders have always been proud of their elms, many of which have been connected with stirring historical events, but none of them has connected with it so much to arouse patriotic enthusiasm as the subject of our sketch.

It is said that before the Revolution audiences gathered under this or a neighboring elm to listen to popular religious and patriotic addresses. The crowning glory in the life of the old elm came, however, when under its branches, Washington took command of the Revolutionary army. The army was encamped in the common, the spirit of Bunker Hill burned in every heart, yet we read that Washington, even at this time, found great trials with which to contend. It is said he had a platform built among the branches of the tree, and no doubt he there meditated upon the plans of campaign and the outcome of the war. Just across the river Charles, scarce five miles away, under another elm in Boston Common, the English soldiers were encamped. We may suspect that the national banner was brought forth to fire the enthusiasm of the patriot army. Tradition says that the stars and stripes, which we all revere so much, were first flung to the breeze near the Washington Elm.

Oliver Wendell Holmes, whose pen was always so apt in expressing true sentiment, says of the tree: "When I first rolled my infant eyes toward the glare of the western sky as it looked through the windows of my birthchamber, four green masses, each of them a forest waving on a single stem, printed themselves on my retina through my blinking eyelids. One was an old patriarch which fell, I 
think, in the great gale of 18 r $_{5}$. I remembered its stump with a certain reverence. On the opposite side of the Common stood the Washington $\mathrm{E} 1 \mathrm{~m}$, now senile, and soon to be the father and god-father of innumerable canes, picture frames, and other relics. North of that stood a fair, outspread tree which from its form I always called the 'coral fan' and beyond that another, handsome but inconspicuous. These trees entered into my young life as truly as the milk that made its blood. Why should I not love their memory and linger over it ?" The love for the old elms to which Holmes gives expression is just as strong in the hearts of the people of Cambridge now as ever and is not likely to wane. Time widens the influence and what may at one time have been a local sentiment, has now become a national one. No one who knows the history of the Washington Elm can look upon it without feelings of deep love and reverence for the venerable tree.

For many years the tree has shown the ravages of age. It was towards the close of its vigorous life at the time of the Revolution. No doubt it would have been gone long since had not great pains been taken to repair any damage as far as possible and to brace with supports its weakened trunk. There are now planted in the Common near the old tree several direct descendants of it and when it falls, as fall it must, others will take its place. The memory of the original tree should be preserved, however, for it was "under this tree Washington took command of the American army, July 3, I 775." Probably no tree has been more potent to arouse patriotic feelings in the hearts of men. 
PLANT WORLD-VOL. II.

Plate ViI.

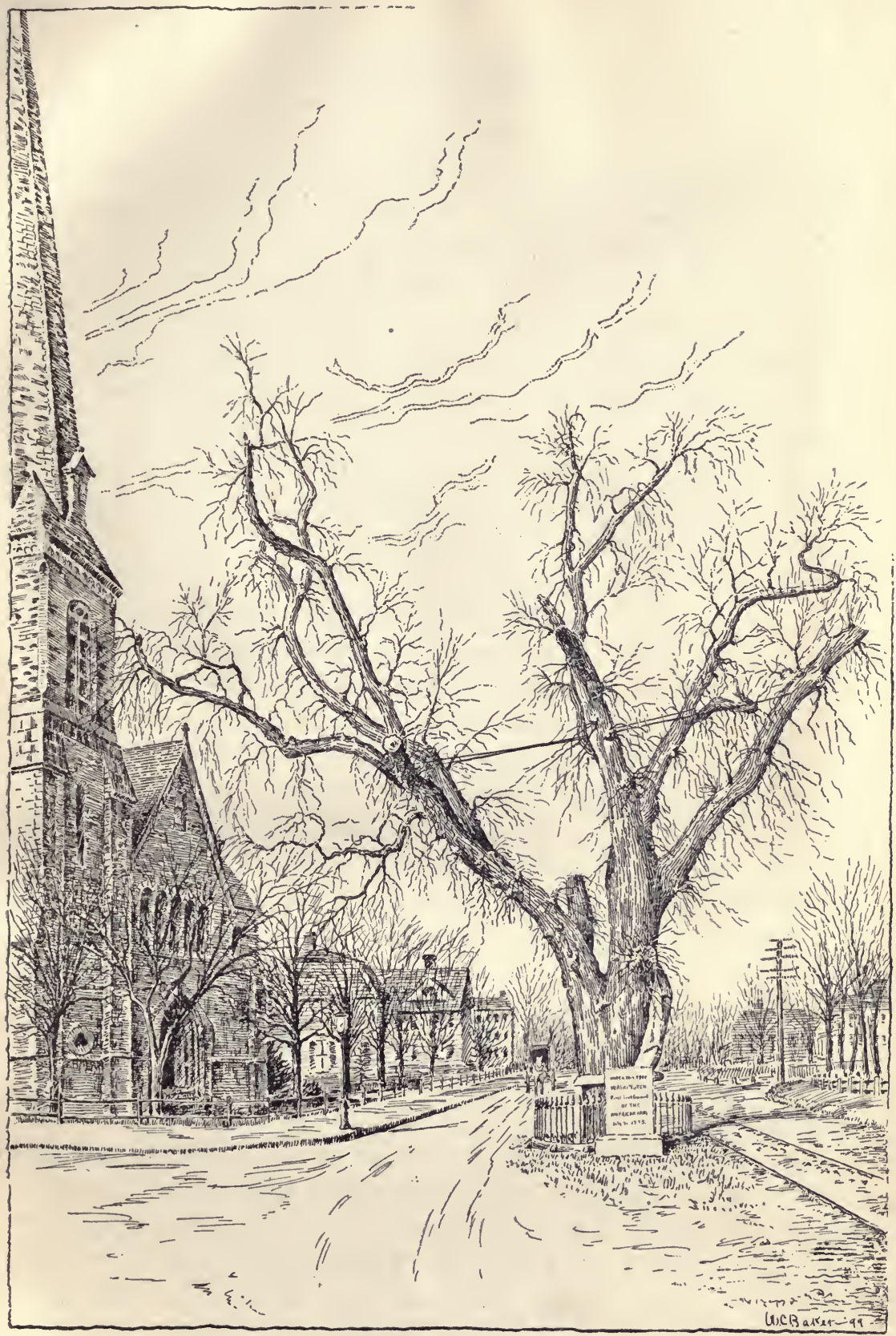

THE WASHINGTON ELM. 


$$
\text { . }
$$




\section{Walter Mulford}

\section{Charles Mohr.}

\section{4-1901.}

Carl Theodor Mohr or Charles Mohr, as he preferred to be known, will be remembered for his many important contributions to natural science. He was born at Esslingen on the Neckar, in Wurttemberg, Germany, December 28, 1824. At an early age he took a deep interest in scientific studies, and embraced every opportunity for extending his knowledge. Soon after his father's death, young Mohr devoted his hours after school to practical work in a chemical factory at Denkendorf, in which his father had been interested. His taste for the sciences was further developed by reading, and his love of nature was awakened by companionship with his great-uncle, a pensioned government forester, whom he frequently joined in his excursions into neighboring forests.

At the age of eighteen Mohr entered the Polytechnic School at Stuttgart, where he became interested in botany. Here he formed the acquaintance of the botanists Hohenacker and Kappler. In 1845 he accompanied Kappler on one of his botanical explorations to Dutch Guiana. Returning to Europe after a protracted illness, Dr. Mohr became chemist for a manufacturing firm in Brunn, Austria. But the political disturbances of 1848 impelled him to leave Europe for the United States, where the remainder of his life, extending over more than fifty years, was passed.

Dr. Mohr brought to America the same enthusiasm that had characterized his work in Europe, and that ever after constituted one of the marked traits of his character. After a short residence in Cincinnati in the employ of a manufacturing chemist, in March, 1849, he joined a party of young men on their way to the newly discovered gold diggings in California. During his long journey across the Plains and Rocky Mountains he again became deeply interested in botanical research, although his efforts were attended with singular misfortune. $\mathrm{He}$ was obliged to abandon one valuable collection of plants 
while crossing the Plains, and after he had given up the search for gold on account of ill health and was on his way to the East again, he was robbed of another at Panama. This last mishap was especially unfortunate, for Dr. Mohr was one of the earliest botanists to explore central California. To him personally the whole venture had serious consequences, for the passage of the Isthmus brought a return of his illness and the permanent impairment of his health. After trying farming in Indiana and the drug business in Louisville, Kentucky, continued illness forced him to go South. Louisville and Mexico both failed to give him the relief he sought; but in 1857 he found a favorable climate in Mobile, Alabama, where he settled and established a prosperous drug business.

His residence at Mobile was of great value to the scientific world, for he found time to study the resources of the region as no one else has done. His published papers are numerous, and much of his work is of great practical value. His botanical researches were extensive and comprised studies of all the indigenous and exotic plants of Alabama. He made a special study of the useful foreign plants acclimated in the Gulf States and published an account of them. In addition to these studies he investigated, in the interest of agriculture, the chemical values of wood ashes, pine straw, and other forest products. He also studied the geology of Alabama from an economic standpoint.

Branching out from botanical and geological work, Dr. Mohr took up the economic study of Southern forests.

He made large collections of commercial wood specimens and forest products which were installed at various State expositions. He contributed largely both to the Jesup wood collection of the American Museum of Natural History, New York City, and to the Arnold Arboretum of Harvard University. He collected and arranged the agricultural, forest and mineral exhibits at the World's Exposition in New Orleans in I884. He supplied much valuable material concerning the distribution, commercial yield and uses of Southern timber trees, for the special report upon the forests of the United States included in Vol. IX of the Tenth Census. 
In 1894 he was appointed an agent in the Division of Forestry, U. S. Department of Agriculture, and subsequently Forest Expert, a position which he held until his death. During this period his forest studies included an investigation of the timber pines of the Southern United States, which was published as Bulletin I3 of the Bureau of Forestry, United States Department of Agriculture (1897). He personally selected and directed in the field the collection of all the Southern commercial timbers mechanically tested by the Department of Agriculture from I892 to 1898 . More recently he completed monographic studies of the Red Cedar, White Cedar, Bald Cypress, and of the most important commercial oaks of the Southern States. His monograph on the Red Cedar was published as Bulletin 3 I of the Bureau of Forestry. The remaining monographs are to be published as bulletins of the Bureau of Forestry.

Through all his economic forest investigations Dr. Mohr found time to complete the crowning botanical work of his life, an exhaustive study of the flora of Alabama. This research covered more than forty years, and was recently published both by the State Geological Survey of Alabama and the United States Department of Agriculture, under the title of "Plant Life of Alabama." Fortunately Dr. Mohr was able to revise the proof sheets of this volume, although he was denied the satisfaction of seeing it in completed form before his death - a matter of great regret to him.

In Dr. Mohr a highly scientific spirit was united with broad and liberal thought. His genuine enthusiasm, his great pleasure in rendering assistance to others, his untiring perseverance and singleness of purpose, no less than his sincerity, kindliness and modesty, impressed themselves upon all who knew him.

In his home life Dr. Mohr showed the same affectionate disposition and unselfish devotion. He was married in $185^{2}$, and passed the greater part of his subsequent life at Mobile, Alabama; but in March, I900, he was obliged on account of failing health to take up his residence at Asheville, North Carolina, where he died on July I7, I90I, in his 77 th year. He leaves a devoted family consisting of a wife and several grown sons and daughters.

George B. Sudworth. 

Fi 

RETURN TO the circulation desk of any University of California Library or to the

NORTHERN REGIONAL LIBRARY FACILITY Bldg. 400, Richmond Field Station University of California Richmond, CA 94804-4698

ALL BOOKS MAY BE RECALLED AFTER 7 DAYS

- 2-month loans may be renewed by calling (510) 642-6753

- 1-year loans may be recharged by bringing books to NRLF

- Renewals and recharges may be made 4 days prior to due date.

DUE AS STAMPED BELOW

\section{MAR 032002}


Wrat 2 tarne

7 tetom 16.9 DEC 191966 AEF $30-1953$

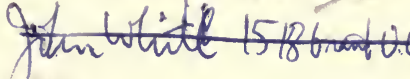
Poter z a Rotter 234Notfol.

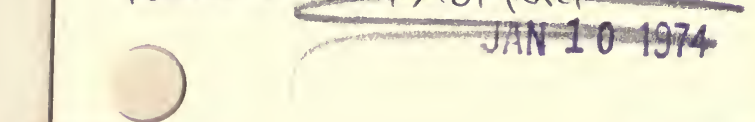

299083

$S D_{3} 121$

UNIVERSITY OF CALIFORNIA LIBRARY 
3 